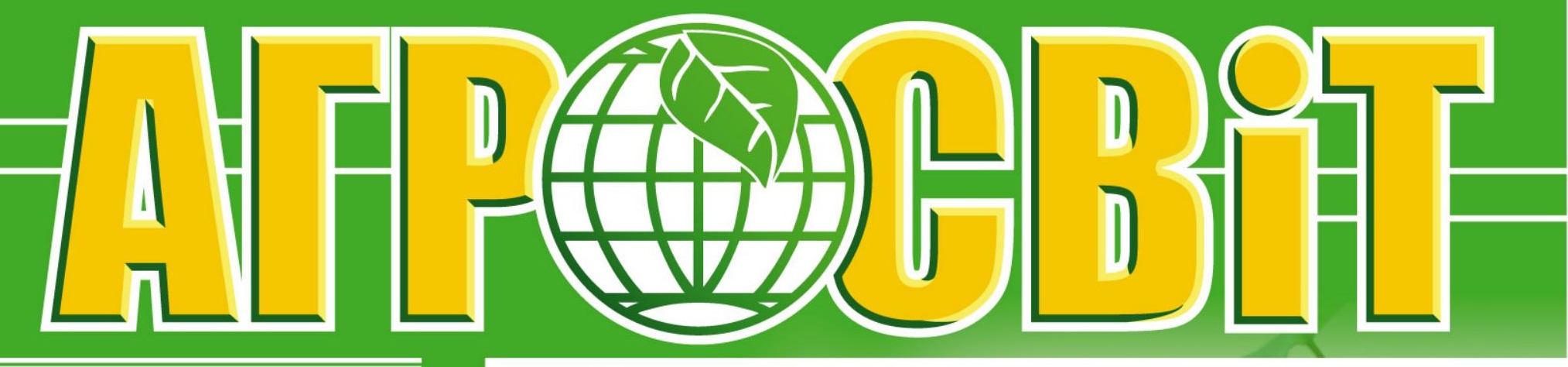

№ 1 січень 2022

Науково-практичнй̆ журнал

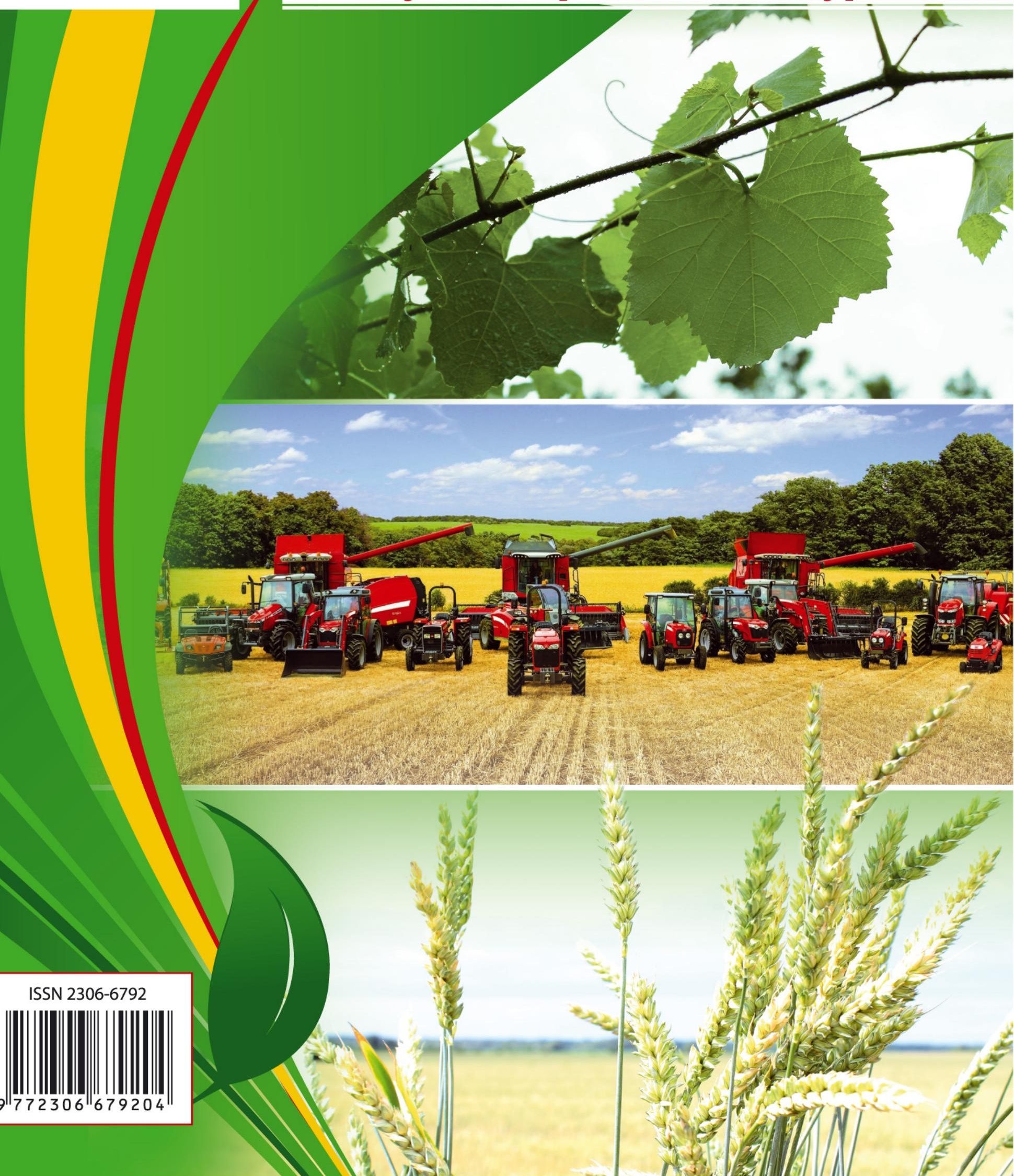


ГОАОВНИЙ РЕААКТОР:

Васильєва Наталя Костянтинівна, доктор економічних наук, професор, завідувач кафедри інформаційних систем і технологій, Аніпровський державний аграрно-економічний університет

ЗАСТУПНИК ГО АОВНОГО РЕААКТОРА: Вініченко Ігор Іванович, доктор економічних наук, професор, завідувач кафедри економіки, Аніпровський державний аграрно-економічний університет

ВІАПОВІАААЬНИЙ СЕКРЕТАР: Кучеренко Г. Б.

\section{ЧАЕНИ РЕААКЦІЙНОÏ КОАЕГІЇ:}

Андрющенко Катерина Анатоліївна, доктор економічних наук, доцент, професор кафедри економіки та підприємництва, АВН3 «Київський національний економічний університет імені Вадима Гетьмана»

Безус Роман Миколайович, доктор економічних наук професор, професор кафедри маркетингу, Аніпровський державний аграрно-економічний університет

Гончаренко Оксана Володимирівна, доктор економічних наук, професор, професор кафедри економіки, Аніпровський державнии аграрно-економічний університет

Аобровальська Олена Володимирівна, доктор економічних наук, доцент, доцент кафедри фінансів, банківсько справи та страхування, Аніпровський державний аграрноекономічнии університет

Козловський Сергій Володимирович, доктор економічних наук, професор, професор кафедри підприємництва корпоративної та просторової економіки, Аонецький національний університет імені Василя Стуса (м. Вінниця)

Каткова Наталя Володимирівна, кандидат економічних наук, доцент, професор кафедри обліку і економічного аналізу, Національний університет кораблебудування ім. адмірала Макарова

Качула Світлана Валентинівна, доктор економічних наук, доцент, професор кафедри фінансів, банківської справи та страхування, Аніпровський державний аграрноекономічний університет

Крючко Иеся Станіславівна, кандидат економічних наук, доцент, доцент кафедри маркетингу, Аніпровський державний аграрно-економічний університет

Кураташвілі Альфред Анзорович (Тбілісі, Грузія), доктор економічних, філософських і юридичних наук, професор в галузі суспільних наук, професор Трузинського технічного університету в області Публічного права (Факультет Права і Міжнародних відносин), науковий керівник Інституту Бізнесу і Права факультетів Права і Міжнародних відносин і Бізнестехнологій ГТУ, завідувач відділом економічної теорії Інституту економіки імені П.Гугушвілі Тбіліського державного університету імені Іване Ажавахішвілі

Иозинський Амитро Иеонідович, кандидат економічних наук, доцент, доцент кафедри обліку і аудиту, Аержавний університет «Житомирська політехніка»

Павлова Галина Євгеніївна, доктор економічних наук, професор, професор кафедри обліку, оподаткування та управління фінансово-економічною безпекою, Аніпровський державний аграрно-економічний університет

Самойленко Алла Олександрівна, кандидат економічних наук, доцент кафедри менеджменту та туристичного бізнесу, Аніпровський національний університет імені Олеся Гончара

Пантєлєєва Наталія Миколаївна, доктор економічних наук, кандидат технічних наук, доцент, доцент кафедри фінансів та банківської справи, Черкаський навчально-науковий інститут Аержавного вищого навчального закладу «Університет банківської справи»

Трусова Наталя Вікторівна, доктор економічних наук, професор, професор кафедри фінансів, банківської справи та страхування Таврійського державного агротехнологічного університету, Таврійський державний агротехнологічний університет

Федоренко Станіслав Валентинович, кандидат технічних наук, доцент, доцент кафедри охорони праці і навколишнього середовища КНУБА, академік академії будівництва України

Халатур Світлана Миколаївна, доктор економічних наук, професор, професор кафедри фінансів, банківськоі справи та страхування, Аніпровський державний аграрноекономічний університет

Череп Олександр Григорович, доктор економічних наук, доцент, професор кафедри економіки, Запорізький національний університет

Чирва Ольга Григорівна, доктор економічних наук, професор, професор кафедри маркетингу, менеджменту та управління бізнесом, Уманський державний педагогічний університет імені Павла Тичини

Шабатура Тетяна Сергіївна, кандидат економічних наук, доцент, доцент кафедри економічної теорії і економіки підприємства, Одеський державний аграрний університет

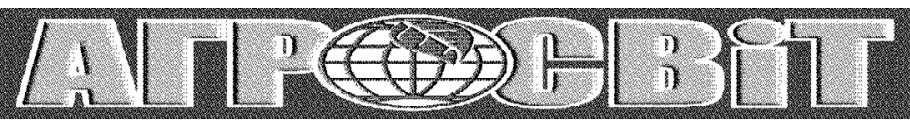

Журнал засновано у січні 2001 року. Виходить 2 рази на місяць.

$$
\text { № } 1 \text { січень } 2022 \text { p. }
$$

Журнал включено до Переліку наукових фахових видань України з

ЕКОНОМІЧНИХ НАУК (Категорія «Б»).

Наказ Міністерства освіти і науки України № 975 від 11.07 .2019 p.

Спеціальності-051,071,072,073,075,076, 292

ІНАЕКСАЦІЯ ВИААННЯ В НАУКОМЕТРИЧНИХ БАЗАХ:

- Index Copernicus (IC);

- SIS;

- Google Scholar.

Свідоцтво КВ № 23728-13568ПР від 27.12.2018 року ISSN 2306-6792

Передплатний індекс: 21847

Адреса редакції:

04112, м. Київ, вул. Аорогожицька, 18, к. 29

Поштова адреса:

04112, м. Київ, вул. Аорогожицька, 18, к. 29

Телефон: (044) 223-26-28, 537-14-33

Тел./факс: (044) 458-10-73

E-mail: economy_2008@ukr.net

www.agrosvit.info

Засновники:

Аніпровсъкий державний аграрно-економічний університет, TOB "АКС Центр"

Видавець:

ТОВ "АКС Центр"

Передрукування дозволяється дише за згодою редакції.

Відповідальність за добір і викладення фактів несуть автори. Редакція не завжди поділяє позицію авторів публікацій.

За зміст та достовірність реклами несе відповідальність рекламодавець.

Рекомендовано до друку Вченою Радою Аніпровського державного аграрно-економічного університету $13.01 .22 \mathrm{p}$. Підписано до друку 13.01.22 р.

Формат 60х84 1/8, Ум. друк. арк. 11,9. Наклад - 1000 прим.

Папір крейдований, друк офсетний. Замовлення № $1301 / 1$.

Відаруковано у ТОВ «АКС Центр» м. Київ, пров. Куренівський, 17 Тел. (044) 537-14-34

(C) Агросвіт, 2022 


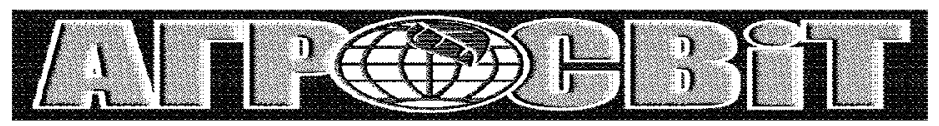

Журнал засновано у січні 2001 року. Виходить 2 рази на місяць.

\section{№ 1 січенъ 2022 р.}

\section{У HOMEPI:}

Третяк А. М., Третяк В. М., Прядка Т. М., Капінос Н. О., Аобунъко Ю. В.

Земельний моніторинг в Україні: поняття та методологія формування

Березіна А. М., Помаз О. М.

Соціально-культурні чинники формування сучасної соціально-економічної системи України

Макарова B. В., Муштай B. A.

Інсайт-технологія при формуванні купівельної поведінки споживачів в умовах запровадження маркетингу

відносин

Данькевич С. М.

Потенціал фінансово-економічного механізму в усуненні дисбалансів лісогосподарського землекористування ............ 27

Горобещь Н. М.

Цифрові технології в системі стратегічного управління аграрними підприємствами

Боскова В. В., Руснак А. В., Надточій I. I.

Сутність бізнес-процесів та процесно-орієнтованого управління у сільськогосподарських підприємствах

Сітковська А. О., Савенко О. А., Капуста М. Ю.

Технічне забезпечення аграрних підприємств як фактор підвищення конкурентоспроможності

Аопушинсъка О. В., Микитенко А. О., Смірнова К. О.

Екологічна складова менеджменту ресурсозбереження аграрних підприємств у контексті забезпечення

стійкого розвитку

Подмешальсъка Ю. В., Решетніков С. В.

Облік, оподаткування та контроль е-лікарняних на торгівельних та промислових підприємствах ....

Чернікова Н. М., Зеленсъкий А. Р.

Антикризове управління сільськогосподарськими підприємствами в умовах пандемії COVID-19

Ерімиева $\Lambda$. О.

Визначення доцільності придбання сільськогосподарськими виробниками основних видів технічних засобів ................ 78 Чугунов В. I.

Бюджетна політика економічного зростання

\section{№ $1 / 2022$}

\section{CONTENTS:}

Tretiak A., Tretiak V., Priadka T., Kapinos N., Lobunko Yu.

LAND MONITORING IN UKRAINE: CONCEPT AND METHODOLOGY OF FORMATION

Berezina L., Pomaz O.

SOCIO-CULTURAL FACTORS OF FORMATION OF THE MODERN SOCIO-ECONOMIC SYSTEM OF UKRAINE

Makarova V., Mushtay V.

INSIGHT TECHNOLOGY IN THE FORMATION OF CONSUMER CONSUMPTION BEHAVIOR

IN CONDITIONS OF RELATIONSHIP MARKETING

Dankevych S.

THE POTENTIAL OF THE FINANCIAL AND ECONOMIC MECHANISM IN ELIMINATING

IMBALANCES IN FORESTRY LAND USE

Gorobets N.

DIGITAL TECHNOLOGIES IN THE SYSTEM OF STRATEGIC MANAGEMENT OF AGRICULTURAL ENTERPRISES .......... 36

Boskova V., Rusnak A., Nadtochii I.

THE ESSENCE OF BUSINESS-PROCESSES AND PROCESS-ORIENTED MANAGEMENT IN AGRICULTURAL

ENTERPRISES ................................................

TECHNICAL SUPPORT OF AGRICULTURAL ENTERPRISES AS A FACTOR OF INCREASING COMPETITIVENESS ..........53

Lopushynska O., Mykytenko A., Smyrnova K.

ECOLOGICAL COMPONENT OF RESOURCE SAVING MANAGEMENT OF AGRICULTURAL ENTERPRISES

IN THE CONTEXT OF ENSURING SUSTAINABLE DEVELOPMENT

Podmeshalska Yu., Reshetnikov S.

ACCOUNTING, TAXATION AND CONTROL OF E-HOSPITALS IN COMMERCIAL AND INDUSTRIAL ENTERPRISES ..... 65

Chernikova N., Zelenskyi D.

ANTI-CRISIS MANAGEMENT OF AGRICULTURAL ENTERPRISES

IN CONDITIONS OF COVID-19 PANDEMIC

Yefimtseva L.

DETERMINING THE FEASIBILITY OF PURCHASING BASIC TYPES OF TECHNICAL MEANS BY AGRICULTURAL

PRODUCERS

Chugunov V. 


\title{
УAK 332.2.01:332.36
}

А. М. Третяк, А. е. н., професор, член-коресподент НААН України,

Білоцерківський національний аграрний університет

ORCID ID: 0000-0002-1154-4797

B. M. Третяк,

А. е. н., професор, Сумський національний аграрний університет

ORCID ID: 0000-0001-6779-1941

T. М. Прядка,

к. е. н., Аоцент, Білоцерківський національний аграрний університет,

ORCID ID: 0000-0002-6179-0128

H. O. Капінос,

к. е. н., Аоцент кафедри геодезії та землеустрою,

Сумський національний аграрний університет

ORCID ID: 0000-0002-9354-5311

Ю. В. Мобунько,

к. е. н., Подільський державний університет

ORCID ID: 0000-0003-1695-9315

DOI: $10.32702 / 2306-6792.2022 .1 .3$

\section{ЗЕМЕАЬНИЙ МОНІТОРИНГ В УКРАЇНІ: ПОНЯТТЯ ТА МЕТОАОЛОГІЯ ФОРМУВАННЯ}

\author{
A. Tretiak, \\ Doctor of Economic Sciences, Professor, Chief Researcher, Bila Tserkva National Agrarian University \\ V. Tretiak, \\ Doctor of Economic Sciences, Professor, Professor of the Department of Geodesy and Land Management, \\ Sumy National Agrarian University \\ T. Priadka, \\ $\mathrm{PhD}$ in Economics, Associate Professor, Bila Tserkva National Agrarian University \\ N. Kapinos, \\ $\mathrm{PhD}$ in Economics, Associate Professor of the Department of Geodesy and Land Management, \\ Sumy National Agrarian University \\ Yu. Lobunko, \\ $\mathrm{PhD}$ in Economics, State Podillia University
}

\section{LAND MONITORING IN UKRAINE: CONCEPT AND METHODOLOGY OF FORMATION}

Обгрунтовано, що система земельного моніторингу в Україні повинна вкдючати такі види: моніторинг земель, моніторинг грунтів, моніторинг земельних відносин, моніторинг землекористування та комплексний моніторинг, який включає територіальний моніторинг, моніторинг окремих об'єктів, моніторинг обігу земельних ділянок (ринку земель). Визначено, що під поняттям "моніторинг землекористування", розуміється система спостереження, оцінки та прогнозу процесів змін форм землекористування, розмірів землеволодінь та землекористувань, дотримання режиму вимогам сталого (збалансованого) землекористування, методів екологічно раціонального використання земель 3 метою своєчасного виявлення змін, їх оцінки небезпеки, відвернення та ліквідації наслідків негативних процесів. Визначено види, об'єкти та періодичність державного та самоврядного земельного моніторингу. Зокрема, до видів земельного моніторингу віднесено: моніторинг стану об'єктів, моніторинг використання та охорони земель (землекористування), моніторинг земельних відносин та обігу земельних ділянок. Визначено, що методологічною основою формування системи основних складових земельного моніторингу в Україні. Система включає: моніторинг природних умов, моніторинг стану грунтового покриву, моніторинг стану поверхневих і грунтових вод, моніторинг стану рослинності, моніторинг стану земної поверхні, моніторинг забруднення земель та грунтів, моніторинг земельнокадастрових Ааних, моніторинг форм та режиму землекористування, моніторинг земельних відносин, моніторинг обігу земельних ділянок та прав на них та ключову складову земельного моніторингу — визначення можливої шкоди віА природних та антропогенних впливів на об'єкти моніторингу, резервів Аля подолання наслідків негативних процесів та впливів і оптимальних способів дюдської діяльності. 
It was found that as of 2021, the ideological paradigm of the formation of a land monitoring system has not been formed in Ukraine. In particular, it was found that in world practice the term monitoring of lands is used almost 15 times more often (6,410 million) than land use monitoring (440 million) and almost 18 times more than monitoring of land resources (364 million). At the same time, in Ukraine monitoring of lands is used more than 2 times less (0.4 million) than land use monitoring ( 0.9 million) and almost 2 times less than monitoring of land resources $(0.8$ million). However, the most common term in Ukraine as of December 2021 is "land monitoring" (4.8 million times). In order to monitor and assess the state of land, land resources, land relations, land use and market circulation of land parcels, a system of land monitoring should be created (as part of national monitoring of the environment and socio-economic processes). The land monitoring system in Ukraine should include the following types: monitoring of lands, soil monitoring, land relations monitoring, land use monitoring and comprehensive monitoring, which includes territorial monitoring, monitoring of individual objects, monitoring of land plots circulation (land market). It has been determined that the concept of "land use monitoring" is understood as a system of observation, assessment and forecasting of processes of changes in land use forms, land tenures and land uses, compliance with the requirements of sustainable (balanced) land use, methods of environmentally sound land use in order to timely identify changes, their hazard assessment, prevention and elimination of the consequences of negative processes. The types, objects and frequency of state and self-governing land monitoring have been determined. In particular, the types of land monitoring include: monitoring of the state of objects, monitoring of the use and protection of land (land use), monitoring of land relations and circulation of land plots. The objects of land monitoring include: lands of state, communal and private property, territories of settlements, nature reserve fund and others, reference land plots, territories of nature reserve fund, land uses, etc., land plots or their groups as land tenure and land use. The methodological basis for the formation of the system of the main components of land monitoring in Ukraine was determined. The system includes: monitoring of natural conditions, monitoring of the state of the topsoil, monitoring of the state of surface and ground waters, monitoring of the state of vegetation, monitoring of the state of the earth's surface, monitoring of land and soil pollution, monitoring of land cadastral data, monitoring of forms and regime of land use, monitoring of land relations, monitoring the circulation of land plots and rights to them and a key component of land monitoring is the assessment of possible damage from natural and anthropogenic influences on monitored objects, reserves to overcome the consequences of negative processes and influences and optimal ways of human activity.

Ключові слова: земельний моніторинг, моніторинг земель, моніторинг земельних відносин, моніторинг землекористування, система моніторингу.

Key words: land monitoring, monitoring of lands, land relations monitoring, land use monitoring, monitoring system.

\section{ПОСТАНОВКА ПРОБЛЕМИ}

Згідно зі статтею 191 Земельного кодексу України [1] моніторинг земель - це система спостереження за станом земель з метою своєчасного виявлення змін, їх оцінки, відвернення та ліквідації наслідків негативних процесів. У системі моніторингу земель проводиться збирання, оброблення, передавання, збереження та аналіз інформації про стан земель, прогнозування їх змін і розроблення науково обгрунтованих рекомендацій для прийняття рішень щодо запобігання негативним змінам стану земель та дотримання вимог екологічної безпеки.

Водночас постановою Кабінету Міністрів України від 23 серпня 2017 р. № 639 "Про реалізацію пілотного проєкту щодо проведення моніторингу земельних відносин та внесення змін до деяких постанов Кабінету Міністрів України" [2] запроваджено ще один термін "моніторинг земельних відносин". Згідно із пунктом 2 Порядку реалізації пілотного проєкту щодо проведення моніторингу земельних відносин, моніторинг земельних відносин - це систематичний збір, збереження, узагальнення та оприлюднення інформації про стан земельних відносин, яка надається суб'єктами інформаційної взаємодії, згідно з рекомендованим переліком даних та показників, які подаються в процесі інформаційної взаємодії для проведення моніторингу [3].

Згідно зі статтею 25 закону України "Про оцінку земель" [4] моніторинг ринку земель здійснюється у складі моніторингу земельних відносин центральним органом виконавчої влади, що реалізує державну політику у сфері зе- 
Таблиця 1. Тезаурусний каркас напрямів розвитку термінів "моніторинг земель", "моніторинг земельних відносин", "моніторинг землекористування"

\begin{tabular}{|l|l|}
\hline \multicolumn{1}{|c|}{ Мовні фрейми та категорії } & \multicolumn{1}{|c|}{ Згадування } \\
в Google, тис.
\end{tabular}

Google (гугл) - назва однієї з найпотужніших пошукових систем у Всесвітній мережі інтернет.

мельних відносин, на підставі відомостей Аержавного реєстру речових прав на нерухоме майно та їх обтяжень про ціну (вартість) земельних ділянок, ціну (вартість) інших речових прав на земельні ділянки, розмір плати за користування чужими земельними ділянками. Результати моніторингу ринку земель публікуються не менше одного разу на три місяці. Моніторинг ринку земель здійснюється у порядку, встановленому Кабінетом Міністрів України.

Законодавством України [5] введено також поняття моніторинг грунтів землях сільськогосподарського призначення, який є складовою частиною державної системи моніторингу довкілля і являє собою систему спостережень, збирання, оброблення, передавання, збереження та аналізу інформації про зміни показників якісного стану грунтів, їх родючості, розроблення науково обгрунтованих рекомендацій щодо прийняття рішень про відвернення та ліквідацію наслідків негативних процесів.

Також у науковій літературі функціонують терміни "моніторинг ринку земель" та "моніторинг землекористування". В цьому зв'язку нами проведено дослідження тезаурусного каркасу напрямів розвитку термінів "моніторинг земель", "моніторинг земельних відносин", "моніторинг землекористування", "моніторинг ринку земель" у світовій практиці (табл. 1).

Як свідчать дані таблиці 1, у світовій практиці термін моніторинг земель вживається майже в 6,5 тис. разів частіше (5 $900 \mathrm{млн)} \mathrm{ніж} \mathrm{мон-}$ іторинг землекористування (440 млн) та майже 18 разів ніж моніторинг земельних ресурсів (364 млн). Водночас в Україні моніторинг земель вживається більш як у 2 рази менше $(0,4$ млн) ніж моніторинг землекористування $(0,9$ млн $)$ та майже в 2 рази менше ніж ніж моніторинг земельних ресурсів (0,8 млн). Однак, найбільш вживаним станом на грудень 2021 р. в Україні $€$ термін "земельний моніторинг" (4,8 млн раз). У світовій практиці термін "Land monitoring" займає одне із провідних місць (5 220 млн запитів). Відповідно, постає питання дослідження поняття та сутності термінів "моніторинг земель", "моніторинг землекористування" та недавно запроваджений термін "моніторинг земельних відносин" і узагальнюючого "земельний моніторинг".

\section{МЕТА ДОСЛІДЖЕННЯ}

Метою статті є дослідження поняття земельного моніторингу в Україні та методології формування його системи.

\section{ВИКЛАД ОСНОВНОГО МАТЕРІАЛУ ДОСЛІДЖЕННЯ}

Інформація про стан навколишнього природного середовища, зміни цього стану використовується людиною давно. Останні сто 3 лишком років спостереження ведуться регулярно: досить згадати про метеорологічні та деякі інші спостереження [6]. 3 розвитком техніки, коли в людини дедалі більше з'являється можливість впливати на земельні ресурси та природу, перетворювати їх, геофізична інформація стає дедалі важливішою. За допомогою такої інформації можна визначити оптимальні природні умови для здійснення різних заходів, передбачити як сприятливі, так і несприятливі фактори для господарювання, вживати заходів для зменшення впливу несприятливих умов на життя та діяльність людей. Ао складу такої інформації входять дані спостережень за станом навколишнього природного середовища, в тому числі земельних ресурсів, прогно- 
зи змін природних умов та стану експлуатації земель.

Відомо, що стан земельних ресурсів та біосфери змінюється під впливом природних та антропогенних впливів на них. Тривалий час спостереження проводилися лише за станом та змінами природного середовища, зумовленими природними причинами. Оскільки стан земельних ресурсів та біосфери змінюється під впливом сукупності антропогенних та природних факторів для того, щоб виділити антропогенні зміни на тлі природних, виникла потреба в організації спеціальних спостережень за їх змінами під впливом людської діяльності.

Систему повторюваних спостережень одного і більше елементів навколишнього природного середовища у просторі та в часі $з$ певними цілями та відповідно до заздалегідь підготовленої програми було запропоновано назвати моніторингом [6].

Термін "моніторинг" виник перед проведенням Стокгольмської конференції Організації Об'єднаних Націй з навколишнього середовища (Стокгольм, 5-16 червня 1972 р.). Перші пропозиції щодо такої системи були розроблені експертами спеціальнӧ̈ комісії СКОПЕ (Науковий комітет 3 проблем навколишнього природного середовища) у 1971 р. Згадки про цю систему можна знайти у рекомендаціях Стокгольмської конференції. Сам термін "моніторинг", мабуть, з'явився на противагу (або на додаток) терміну "контроль", до трактування якого включалися як спостереження та отримання інформації, а й елементи активних дій, елементи управління.

Тоді дискусія велася з моніторингу забруднень, тоді як моніторингу природних ресурсів приділялася лише невелика увага.

У нашій країні обговорення системи моніторингу активізувалося перед першою міжурядовою нарадою з моніторингу, скликаною в Найробі (Кенія, лютий 1974 р.) Радою керуючих Програми ООН з проблем довкілля (ЮНЕП); слід підкреслити, однак, що спостереження за багатьма змінами в біосфері здійснювалися і раніше, зокрема Гідрометеорологічною службою СРCP CCCP [6].

Основні положення щодо створення системи моніторингу земель в Україні були закладені в постанові Кабінету Міністрів України від 20 серпня 1993 р. № 661 "Про затвердження Положення про моніторинг земель" [7]. Зокрема, положенням було визначено, що моніторинг земель - це система спостереження за станом земель з метою своєчасного виявлення змін, їх оцінки, відвернення та ліквідації наслідків негативних процесів. Об'єктом моніторингу було визначено всі землі незалежно від форми власності на них. Складовою частиною моніторингу земель є моніторинг грунтів. Положенням було визначено, що залежно від мети спостережень та ступеня охоплення територій моніторинг земель проводиться як:

- національний - на всіх землях у межах території України;

- регіональний - на територіях, що характеризуються єдністю фізико-географічних, екологічних та економічних умов;

- локальний - на окремих земельних ділянках та в окремих частинах (елементарних структурах) ландшафтно-екологічних комплексів.

Иокальний моніторинг ведеться на територіальних об'єктах нижче за регіональний рівень, аж до територій окремих землекористувань та територіальних громад. У межах адміністративно-територіального поділу моніторинг земель містить підсистеми, які відповідають категоріям земель підсистеми, що відповідає відповідній категорії земель.

Також положенням [7] визначено, що моніторинг земель складається із систематичних спостережень за станом земель (агрохімічна паспортизація земельних ділянок, зйомка, обстеження і вишукування), виявлення у ньому змін, а також проведення оцінки:

- процесів, пов'язаних із змінами родючості грунтів (розвиток водної і вітрової ерозії, втрата гумусу, погіршення структури грунту, заболочення і засолення), заростання сільськогосподарських угідь, забруднення земель пестицидами, важкими металами, радіонуклідами та іншими токсичними речовинами;

- стану берегових ліній річок, морів, озер, заток, водосховищ, лиманів, гідротехнічних споруд;

- процесів, пов'язаних з утворенням ярів, зсувів, сельовими потоками, землетрусами, карстовими, кріогенними та іншими явищами;

- стану земель населених пунктів, територій, зайнятих нафтогазодобувними об'єктами, очисними спорудами, гноєсховищами, складами пально-мастильних матеріалів, добрив, стоянками автотранспорту, захороненням токсичних промислових відходів і радіоактивних матеріалів, а також іншими промисловими об'єктами.

Таким чином, об'єктами моніторингу земель є процеси, що можуть бути небезпечні для зниження родючості грунтів або життєдіяльності людей. 


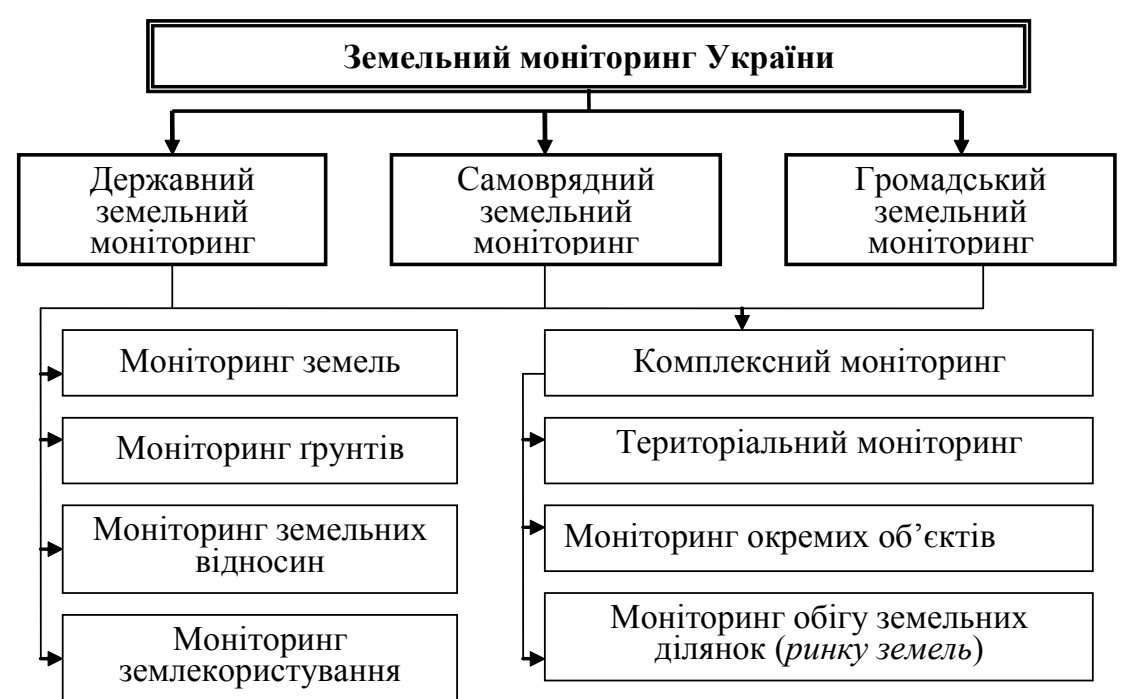

Рис. 1. Система земельного моніторингу в Україні

Актуальність моніторингу земель обумовлена тим, що рівень екологічно допустимого на землю у ряді регіонів країни перевищено, існує реальна загроза повного виснаження та забруднення земель. Серйозну небезпеку становлять опустелювання земель, ерозія грунтів, виснаження родючого шару, засолення земель, заболочування та перезволоження земель, деградація пасовищ та сінокосів, масове підтоплення земель, техногенне забруднення земель.

Моніторинг земель реалізує три основні функції, притаманні будь-якому моніторингу: спостереження, оцінка, прогноз. Спостереження полягає у зборі інформації про джерела природних та антропогенних впливів на об'єкт, про реакцію навколишнього природного середовища на дію цих джерел, а також про стан здоров'я та життєдіяльності населення. Оцінка передбачає визначення можливої шкоди від природних та антропогенних впливів на об'єкт, визначення можливих резервів для подолання наслідків негативних процесів та впливів, а також визначення оптимальних способів людської діяльності як з економічної, так і з екологічної позиції. Прогноз передбачає виявлення оптимальних способів усунення причин та умов можливих негативних змін у стані земель.

Згідно зі статтею 15-1 земельного кодексу України [1] ведення моніторингу земель відноситься до повноважень центрального органу виконавчої влади, що реалізує державну політику у сфері земельних відносин, станом на 2022 р. це Аержгеокадастр України. На жаль, за всі роки земельної реформи цей орган виконавчої влади так і не зміг створити систему моніторингу земель, яка на наш погляд, повинна вкдючати (рис. 1): державний моніторинг, самоврядний та громадський моніторинг.
Земля, в т.ч. земельні ресурси, як частина навколишнього природного середовища, $є$ необхідною складовою для життєдіяльності людини. 3 метою відстеження та оцінки стану земель, земельних ресурсів, земельних відносин, землекористування та ринкового обігу земельних ділянок повинна бути створена система земельного моніторингу (як складова частина національного моніторингу навколишнього природного середовища та соціально-економічних процесів).

Під час земельного моніторингу виявляються такі процеси:

- еволюційні (пов'язані з природно-історичними процесами розвитку);

— циклічні (пов'язані з сезонними, річними та іншими періодами змін природного та соціально-економічного характеру);

— антропогенні (пов'язані з діяльністю людини);

— надзвичайні ситуації (пов'язані з небезпеками для життєдіяльності людей).

Із наведених видів земельного моніторингу новим видом $є$ моніторинг землекористування, який представляє систему спостереження, оцінки та прогнозу процесів змін форм землекористування, розмірів землеволодінь та землекористувань, дотримання режиму вимогам сталого (збалансованого) землекористування, методів екологічно раціонального використання земель з метою своєчасного виявлення змін, їх оцінки небезпеки, відвернення та ліквідації наслідків негативних процесів. Методологія та інституціолізація моніторингу землекористування потребує більш поглиблених подальших досліджень.

Земельний моніторинг проводиться як цілісна система поділяється на три частини: 


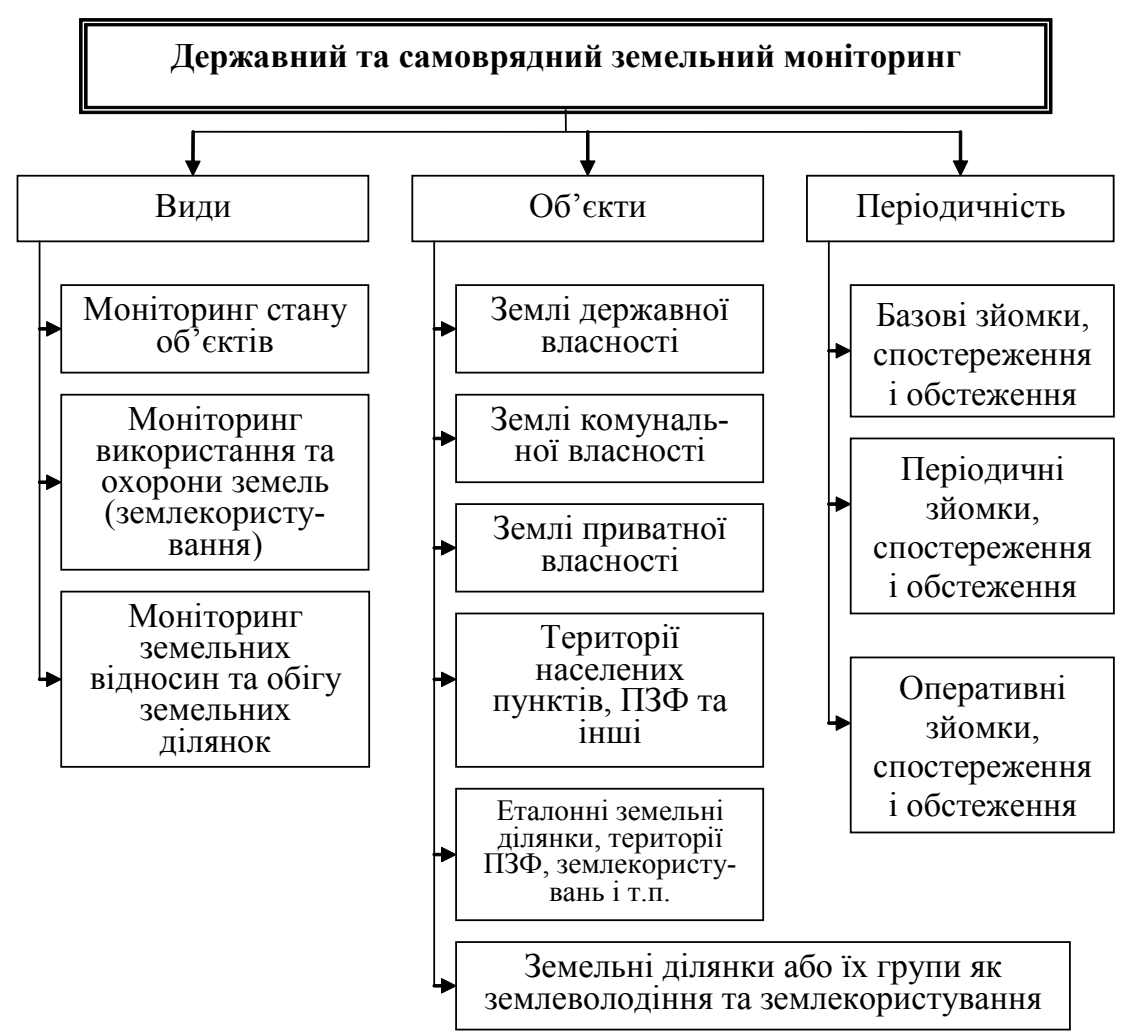

Рис. 2. Види, об'єкти та періодичність державного та самоврядного земельного моніторингу

державний моніторинг, самоврядний моніторинг та громадський (недержавний) земельний моніторинг.

Аержавний земельний моніторинг здійснюється суворо на основі чинного національного законодавства органами державної влади. Окреме місце у системі земельного моніторингу займає моніторинг, що проводиться органами місцевого самоврядування. Його особливість визначається статусом останніх. Такий моніторинг може входити як складова частина до системи державного моніторингу, якщо він виконується в рамках державної програми, а може розглядатися як самоврядний моніторинг, якщо він проводиться органами місцевого самоврядування на основі нормативних актів, прийнятих органами місцевого самоврядування.

Недержавний (громадський) земельний моніторинг здійснюється громадськими організаціями, підприємствами, установами. Громадський земельний моніторинг, зазвичай, немає нормативно-правової бази чіткого характеру.

При проведенні земельного моніторингу його об'єкти вивчаються відповідно до встановлених для них категорій, правового режиму та видів дозволеного використання. Кожен об'єкт земельного моніторингу описується набором показників, що визначають його стан та використання. Види, об'єкти та періодичність земельного моніторингу представлено на рисунку 2.

Спостереження за станом земель залежно від строку та періодичності їх проведення поділяються на:

— базові (вихідні, що фіксують стан об'єкта спостережень на момент початку ведення моніторингу земель);

- періодичні (проводяться через рік і більше);

- оперативні (фіксують поточні зміни).

Земельний моніторинг передбачає спостереження за станом і використання земель, безпекою життєдіяльності людей, пов'язаною із землекористуванням, зміною форм та режиму землекористування тощо. Такий моніторинг формує інформаційну базу для здійснення державного земельного нагляду, забезпечує органи влади, організації та громадян інформацією щодо використання земель. 3 появою техніки за допомогою геофізичної та іншої інформації можна передбачити сприятливі та несприятливі фактори для господарювання та вживати заходів щодо зменшення впливу несприятливих умов на життя та діяльність людей. У сучасних економічних умовах прийняттю рішень, пов'язаних з реалізацією дій на землі, обов'язково 


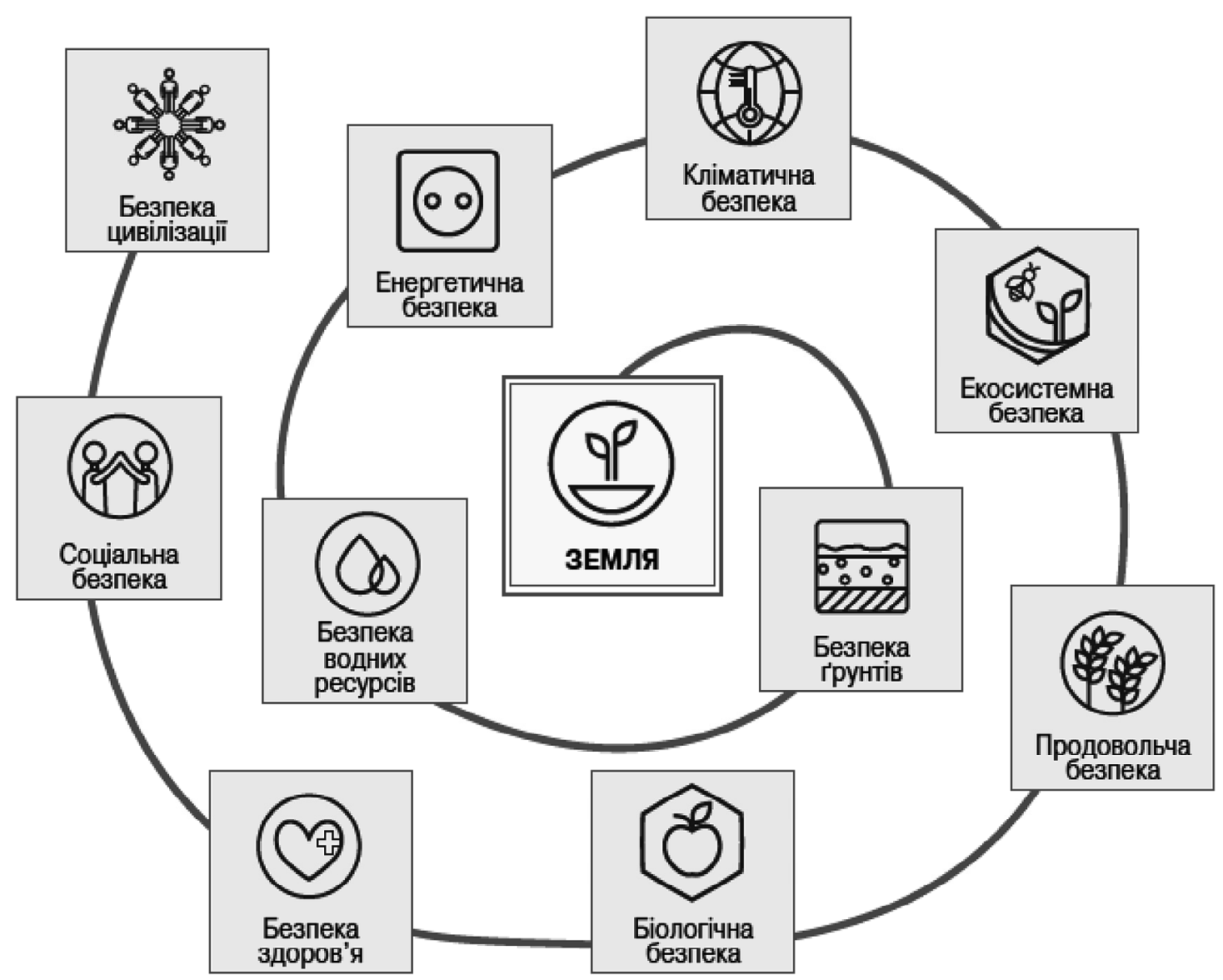

Рис. 3. Логічно-змістовна схема масштабів людської безпеки

має передувати аналіз множини різних достовірних та регулярно обновлюваних даних про стан об'єктів моніторингу.

Збереження функціональності земель, земельних ресурсів та створення умов розвитку сталого (збалансованого) землекористування [8] є важливим внеском у забезпечення безпеки людства: це дає доступ до продовольства і води, стабільну зайнятість і життєзабезпечення, стійкість до зміни клімату і екстремальних погодних явищ, а також (в кінцевому підсумку) соціальну і політичну безпеку. На рисунку 3 наведено логічнозмістовну схему масштабів людської безпеки, що розроблена з використанням джерела [9].

У системі управління земельними ресурсами та землекористування, а відповідно і в системі земельного моніторингу, види безпеки поділяються на ієрархічні рівні управління. Зокрема, заходи із забезпечення: безпеки грунтів та водних ресурсів як правило повинні здійснюватися на місцевому - рівні об'єднаних територіальних громад, енергетична, екосистемна, продовольча, біологічна безпеки як правило реалізовуються на регіональному та на- ціональному рівнях, безпека здоров'я та соціальна як правило, реалізовуються на національному рівні, кліматична та цивілізаційна безпеки як правило реалізовуються на національному та глобальному рівнях. Відповідно до вказаних рівнів повинні розроблятися показники (індикатори) в розрізі видів земельного моніторингу.

На жаль, сьогодні в Україні землю (у виді землекористування) на урядовому рівні не розглядають як земну біопродуктивну систему, що включає в себе грунт, рослинність, іншу біомасу, а також екологічні і гідрологічні процеси, які відбуваються всередині цієї системи. А відповідно із станом та якістю землекористування не пов'язується комплекс безпекових загроз життєдіяльності людини. Іншими словами, поняття "земля" включає всю екологічну систему, в якій знаходиться земельна ділянка, тобто, весь комплекс факторів навколишнього природного середовища та природних умов виробництва, які визначають зростання та розвиток рослин, умови сільськогосподарського та іншого землекористування i, в кінцевому рахунку, визначають фактичний стан земель (земельних ресурсів), зміни якого 


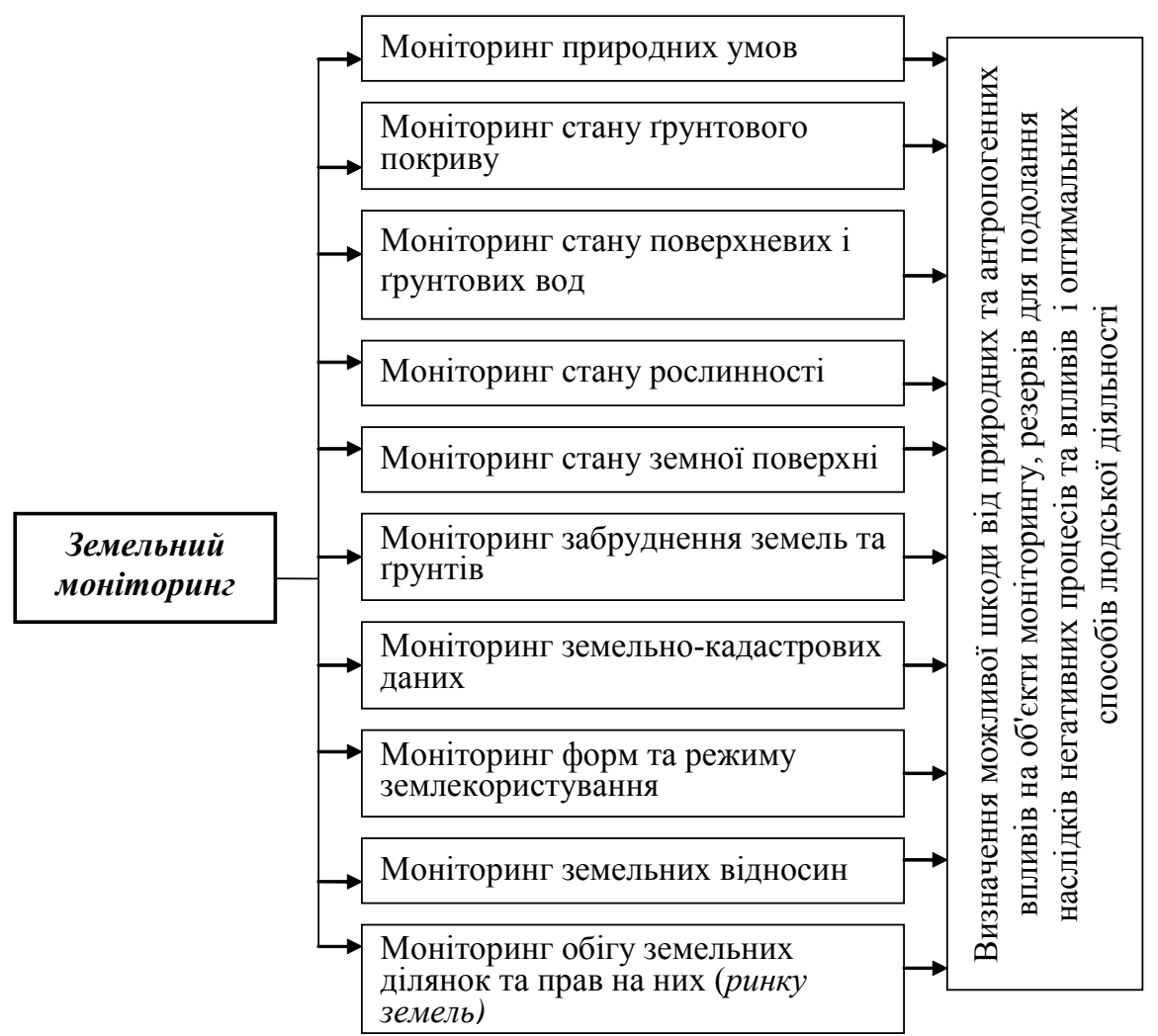

Рис. 4. Методологічна структура формування системи основних складових земельного моніторингу в Україні

є кінцевою метою земельного моніторингу. При цьому, основною складовою "землі" як складного природно-господарського комплексу прийнято вважати грунтовий покрив, рослинність тощо, які найбільш повно відображають сутність та властивості земельних ресурсів.

Основні завдання земельного моніторингу полягають у оперативному виявленні змін у стані земель та землекористуванні, їх оцінці, виробленні рекомендацій та управлінських рішень для попередження та усунення наслідків негативних процесів, а також в інформаційному забезпеченні державного земельного кадастру, екологічно раціонального землекористування та контролю за використанням і охороною земель.

Очевидно, що вирішення всього комплексу завдань можливе лише в результаті аналізу багатовимірних тимчасових рядів комплексних топографо-геодезичних, грунтових, агрохімічних, геоботанічних, інвентаризаційних, екологічних, економічних та інших спостережень, що відображають зміни у стані всіх складових земельно-господарського комплексу: грунтів, рослинності, грунтових та поверхневих вод, природних умов, що впливають формування та якість земель, ре- жиму землекористування, правових, економічних, екологічних та інших відносин. Крім того, мають бути відображені зміни, що відбулися у правовому та економічному стані землекористування. Виходячи з вищевикладеного, на рисунку 4 сформовано нами методологічну структуру формування системи земельного моніторингу.

Ключовою складовою земельного моніторингу є визначення мождивої шкоди від природних та антропогенних впливів на об'єкти моніторингу, резервів для подолання наслідків негативних процесів та впливів і оптимальних способів людської діяльності.

Крім того, новим напрямом є моніторинг земельних відносин, у тому числі моніторинг ринку земель [10], який здійснюється з метою забезпечення прозорості земельних відносин, а також доступності інформації про їх стан та розвиток. Відповідно до проєкту "Порядку моніторингу земельних відносин, у тому числі моніторингу ринку земель" завданнями такого моніторингу визначено [10]: 1) постійне спостереження за станом та розвитком земельних відносин, здійснення їх аналізу, динаміки змін показників та її прогнозування; 2) підвищення якості надання послуг у сфері земельних відносин; 3) підвищення якості управ- 
ління земельними ресурсами на державному, регіональному та місцевому рівнях; 4) забезпечення контролю за дотриманням правового режиму використання земельних ресурсів; 5) підвищення рівня інвестиційної привабливості та покращення бізнес-клімату в Україні; 6) виявлення у ході обробки об'єктів моніторингу помилок (топологічних, логічних, семантичних й орфографічних) у даних відповідних інформаційних систем та інформування суб'єктів інформаційної взаємодії про їх виявлення. На жаль проєктом порядку не визначено перелік показників моніторингу. Також потребує удосконалення перелік об'єктів моніторингу ринку земель. Адже, проєктом Порядку визначено, що об'єктами моніторингу ринку земель є відомості Аержавного реєстру речових прав на нерухоме майно, про відповідну земельну ділянку з кадастровим номером та площею, а саме: 1) про ціну (вартість) земельної ділянки; 2) про ціну (вартість) інших речових прав на земельну ділянку; 3) про розмір плати за користування чужою земельною ділянкою. А це не $є$ вичерпний перелік. Отже, всі види земельного моніторингу потребують подальших досліджень в єдиній системі як її складові.

\section{ВИСНОВКИ \\ I ПЕРСПЕКТИВИ ПОДАЛЬШИХ РОЗВІДОК}

Встановлено, що 1 у світовій практиці термін моніторинг земель вживається майже в 6,5 тис. разів частіше (5 900 млн), ніж моніторинг землекористування (440 млн) та майже 18 разів ніж моніторинг земельних ресурсів (364 млн). Водночас в Україні моніторинг земель вживається більш як у 2 рази менше $(0,4$ млн) ніж моніторинг землекористування $(0,9$ млн) та майже в 2 рази менше ніж моніторинг земельних ресурсів (0,8 млн). Однак, найбільш вживаним станом на грудень 2021 р. в Україніє термін "земельний моніторинг" (4,8 млн раз). У світовій практиці термін "Land monitoring" займає одне із провідних місць (5 220 млн запитів). 3 метою відстеження та оцінки стану земель, земельних ресурсів, земельних відносин, землекористування та ринкового обігу земельних ділянок повинна бути створена система земельного моніторингу (як складова частина національного моніторингу навколишнього природного середовища та соціально-економічних процесів). Система земельного моніторингу в Україні повинна включати такі види: моніторинг земель, моніторинг грунтів, моніторинг земельних відносин, моніторинг землекористування та комплексний моніторинг, який включає територіальний моніторинг, моніторинг окремих об'єктів, моніторинг обігу земельних ділянок (ринку земель). Визначено, що під поняттям "моніторинг землекористування", розуміється система спостереження, оцінки та прогнозу процесів змін форм землекористування, розмірів землеволодінь та землекористувань, дотримання режиму вимогам сталого (збалансованого) землекористування, методів екологічно раціонального використання земель 3 метою своєчасного виявлення змін, їх оцінки небезпеки, відвернення та ліквідації наслідків негативних процесів. Визначено види, об'єкти та періодичність державного та самоврядного земельного моніторингу. Зокрема, до видів земельного моніторингу віднесено: моніторинг стану об'єктів, моніторинг використання та охорони земель (землекористування), моніторинг земельних відносин та обігу земельних ділянок. Ао об'єктів земельного моніторингу віднесено: землі державної, комунальної та приватної власності, території населених пунктів, ПЗФ та інші, еталонні земельні ділянки, території ПЗФ, землекористувань і т.П., земельні ділянки або їх групи як землеволодіння та землекористування. Визначено, що методологічною основою формування системи основних складових земельного моніторингу в Україні. Система включає: моніторинг природних умов, моніторинг стану грунтового покриву, моніторинг стану поверхневих і грунтових вод, моніторинг стану рослинності, моніторинг стану земної поверхні, моніторинг забруднення земель та грунтів, моніторинг земельно-кадастрових даних, моніторинг форм та режиму землекористування, моніторинг земельних відносин, моніторинг обігу земельних ділянок та прав на них та ключову складову земельного моніторингу - визначення можливої шкоди від природних та антропогенних впливів на об'єкти моніторингу, резервів для подолання наслідків негативних процесів та впливів і оптимальних способів людської діяльності.

Перспективи подальших розвідок заключаються в дослідженні концепції, принципів та методології формування системи земельного моніторингу і особливо моніторингу землекористування та моніторингу обігу земельних ділянок та прав на них (ринку земель).

\section{Мітература:}

1. Земельний кодекс України. URL: ttps://zakon.rada.gov.ua/laws/show/2768-14\#Text 
2. Постанова Кабінету Міністрів України від 23 серпня 2017 р. № 639 "Про реалізацію пілотного проєкту щодо проведення моніторингу земельних відносин та внесення змін до деяких постанов Кабінету Міністрів України". URL: https://zakon.rada.gov.ua/laws/show/639-2017$\% \mathrm{D} 0 \% \mathrm{BF} \# \mathrm{Text}$

3. Постанова Кабінету Міністрів України від 23 серпня 2017 р. № 639 "Про реалізацію пілотного проєкту щодо проведення моніторингу земельних відносин та внесення змін до деяких постанов Кабінету Міністрів України". URL: https://zakon.rada.gov.ua/laws/show/639-2017$\% \mathrm{D} 0 \% \mathrm{BF} \# \mathrm{Text}$

4. Закон України "Про оцінку земель". URL: https://zakon.rada.gov.ua/laws/show/1378$15 \#$ Text

5. Наказ Міністерства аграрної політики України від 26.02.2004 N 51 "Про затвердження Положення про моніторинг грунтів на землях сільськогосподарського призначення". URL: https://zakon.rada.gov.ua/laws/show/z038304\#Text

6. Израэль Ю.А. Экология и контроль состояния природной среды. $\Lambda .:$ Гидрометеоиздат, 1979.

7. Постанова Кабінету Міністрів України від 20 серпня 1993 р. № 661 "Про затвердження Положення про моніторинг земель". URL: https://zakon.rada.gov.ua/laws/show/661-93$\%$ D0\%BF\#Text

8. Третяк A.M., Третяк B.M., Трофименко П.I., Прядка Т.М., Трофименко Н.В. Стале (збалансоване) землекористування: понятійний базис та методологія інституціолізації. Агросвіт. № 23-24. 2021. С. 10-17.

9. Lal R. Food security in a changing climate. Ecohydrology and Hydrobiology. № 13. 2013. Pp. 8-21.

10. Порядок моніторингу земельних відносин, у тому числі моніторингу ринку земель. Проєкт постанови Кабінету Міністрів України. URL: https://land.gov.ua/wp-content/uploads/ 2021/07/\%D0\%9F\%D0\%A0\%D0\%9E\%D0\%95\%D0\%9A \%D0\%A2-\%D0\%9F\%D0\%9E\%D0\%A1\%D0\%A2\%D0\%90\%D0\%9D \%D0\%9E\%D0\%92\%D0\%98-\%D0\%9A\%D0\%90\%D0\%91\%D0\%86\%D 0 \% 9 D \% D 0 \% 95 \% D \% A 2\% D 0\% A 3 - \% D0 \% 9C $\%$ D0 \% 86\%D0\% 9D $\%$ D $0 \% 86 \% \mathrm{D} 0 \%$ A1\%D0\%A2\%D0\%A0\%D0\%86\%D0\%92.pdf

\section{References:}

1. The Verkhovna Rada of Ukraine (2001), "Land Code of Ukraine", available at: http://zakon3.rada.gov.ua/laws/show/2768-14/print1509602912924405 (Accessed 15 Dec 2021).
2. Cabinet of Ministers of Ukraine (2017), Resolution "On the implementation of a pilot project to monitor land relations and amendments on some resolutions of the Cabinet of Ministers of Ukraine", available at: https://zakon.rada.gov.ua/ laws/show/639-2017-\%D0\%BF\#Text (Accessed 15 Dec 2021).

3. Cabinet of Ministers of Ukraine (2017), Resolution "On the implementation of a pilot project to monitor land relations and amendments on some resolutions of the Cabinet of Ministers of Ukraine", available at: https://zakon.rada.gov.ua/ laws/show/639-2017-\%D0\%BF\#Text (Accessed 15 Dec 2021).

4. The Verkhovna Rada of Ukraine (2003), The Law of Ukraine "On Land Valuation", available at: https://zakon.rada.gov.ua/laws/show/137815\#Text (Accessed 15 Dec 2021).

5. Ministry of Agrarian Policy of Ukraine (2004), Order "On approval of the Regulation on monitoring of soils on agricultural lands", available at: https://zakon.rada.gov.ua/laws/show/z038304\#Text (Accessed 15 Dec 2021).

6. Israel, Yu.A. (1979), Jekologija i kontrol' sostojanija prirodnoj sredy [Ecology and control of the state of the natural environment], Gidrometeoizdat, St.Petersburg, Russia, available at: ttps://www.twirpx.com/file/258472/ (Accessed 15 Dec 2021).

7. Cabinet of Ministers of Ukraine (1993), Resolution "On approval of the Regulations on land monitoring", available at: https://zakon.rada.gov.ua/laws/show/661-93-\%D0\%BF\#Text (Accessed 15 Dec 2021).

8. Tretiak, A. Tretiak, V. Trofimenko, P. Pryadka, T. and Trofimenko, N. (2021), "Sustainable (balanced) land use: conceptual basis and methodology of institutionalization", Agrosvit, vol. 2324, pp. $10-17$.

9. Lal, R. (2013), "Food security in a changing climate", Ecohydrology and Hydrobiology, vol. 13, pp. 8-21.

10. Cabinet of Ministers of Ukraine (2021), Draft resolution "Procedure for monitoring land relations, including land market monitoring", available at: https://land.gov.ua/wp-content/ uploads $/ 2021 / 07 / \% \mathrm{D} 0 \% 9 \mathrm{~F} \% \mathrm{D} 0 \% \mathrm{~A} 0 \% \mathrm{D} 0 \% 9 \mathrm{E} \%$ D0\%95\%D0\%9A \%D0\%A2-\%D0\%9F\%D0\%9E\%D0\%A1 \%D0\%A2\%D0\%90\%D0\%9D\%D0\%9E\%D0\%92\%D0\%98-\%D0\%9A \%D0\%90\%D0\%91\%D0 $\% 86 \% \mathrm{D} 0 \% 9 \mathrm{D} \% \mathrm{D} 0 \% 95 \% \mathrm{D} 0 \% \mathrm{~A} 2 \% \mathrm{D} 0 \% \mathrm{~A} 3-$ $\% \mathrm{D} 0 \% 9 \mathrm{C} \% \mathrm{D} 0 \% 86 \% \mathrm{D} 0 \% 9 \mathrm{D} \% \mathrm{D} 0 \% 86 \% \mathrm{D} 0 \% \mathrm{~A} 1 \%-$ D0\%A2\%D0\%A0\%D0\%86\%D0\%92.pdf (Accessed 15 Dec 2021).

Стаття надійшла до редакиії 29.12.2021 p. 
М. М. Березіна, А. е. н., професор, Полтавський державний аграрний університет ORCID ID: 0000-0003-2843-5893

O. М. Помаз, к. е. н., Аоцент, Полтавський Аержавний аграрний університет ORCID ID: 0000-0003-1782-3890

\title{
СОЦІАЛЬНО-КУАЬТУРНІ ЧИННИКИ ФОРМУВАННЯ СУЧАСНОЇ СОЦІААЬНО- ЕКОНОМІЧНОЇ СИСТЕМИ УКРАЇНИ
}

\author{
L. Berezina, \\ Doctor of Economic Sciences, Professor, Poltava State Agrarian University \\ O. Pomaz, \\ $\mathrm{PhD}$ in Economics, Associate Professor, Poltava State Agrarian University
}

\section{SOCIO-CULTURAL FACTORS OF FORMATION OF THE MODERN SOCIO-ECONOMIC SYSTEM OF UKRAINE}

Проаналізовані основні соціально-культурні чинники формування сучасної соціально-економічної системи України. Ао них, зокрема, відносяться: фактори соціально-побутової інфраструктури, фактори соціально-культурної інфраструктури, соціальні ресурси, ментальні фактори. Значну увагу приділено впливу на формування соціальноекономічної системи "влаАа - бізнес - громада" соціальних ресурсів та ментальних факторів. Соціальні ресурси $\epsilon$ вагомим чинником розвитку територіальних громаА, оскільки їх мобілізація та реалізація супроводжується синергетичним ефектом завдяки підвищенню ефективності використання всіх інших видів ресурсів: матеріальних, госпоАарських, природних та ін. У складі соціальних ресурсів як факторів виділені: сім'я, шлюб; релігія, церква; розвиток громадянського суспільства; профспілкова активність і вплив профспілок на формування громадської думки; відносини "підприємство - громадські організації"; територіальні громади як носій соціальних ресурсів; державні органи соціальної роботи з населенням. Наведені ментальні особливості українців мають велике значення Аля розуміння особливостей управління відносинами в соціально-економічній системі "влада - бізнес — громада", зокрема їх ролі у становленні громадянського суспільства, у відносинах з бізнесом і ставленні до влади.

The complex socio-economic system of "government-business-community" contains not only economic, demographic, institutional, natural and environmental, but also socio-cultural elements. Although the socio-cultural component is relatively latent, it nevertheless has a significant impact on the system as a whole. The main socio-cultural factors of formation of the modern socio-economic system of Ukraine are analyzed. These, in particular, include: factors of social infrastructure, factors of socio-cultural infrastructure, social resources, mental factors. The factors of socio-cultural infrastructure include: provision of cultural facilities (theaters, cinemas, dance halls, clubs, libraries); provision of children's preschool institutions, secondary schools; access to higher education institutions of various profiles; development of sports and tourism, providing the population with sports facilities. Considerable attention is paid to the impact on the formation of the socio-economic system "government-business-community" of social resources and mental factors. Social resources are an important factor in the development of territorial communities, as their mobilization and implementation is accompanied by a synergistic effect by improving the efficiency of all other types of resources: material, economic, natural and others. In the composition of social resources as factors are: family, marriage; religion, church; civil society development; trade union activity and the influence of trade unions on the formation of public opinion; relations "enterprise - public organizations"; territorial communities as carriers of social resources; state bodies of social work with the population. These mental characteristics of Ukrainians are of great importance for understanding the peculiarities of governance in the socio-economic system "government-business-community", in particular their 
role in the formation of civil society, in relations with business and attitude to power. The undeniable advantages of the Ukrainian mentality, in this context, are diligence and mastery, friendliness and tolerance to other nationalities, flexibility and adaptability to change. To some extent, this will be facilitated by the gradual departure from the Soviet mentality caused by the change of generations and the growing influence of Western culture and traditions.

Ключові слова: сочіально-економічна система, сочіально-культурні фрактори, сочіальні ресурси, інфраструктура, менталітет.

Key words: socio-economic system, socio-cultural factors, social resources, infrastructure, mentality.

\section{ПОСТАНОВКА ПРОБЛЕМИ У ЗАГАЛЬНОМУ ВИГЛЯДІ ТА ЇЇ ЗВ'ЯЗОК З ВАЖЛИВИМИ НАУКОВИМИ ТА ПРАКТИЧНИМИ ЗАВДАННЯМИ}

Сучасна соціально-економічна система $\mathrm{У}_{\mathrm{K}-}$ раїни продовжує перебувати на етапі становлення і трансформації у відносно ефективну ліберально-капіталістичну соціально орієнтовану ринкову модель організації суспільства. Ці процеси прискорилися у 2014 році, коли Україна стала активніше інтегруватися у європейський та світовий соціально-економічний простір, проте ситуація ускладнюється фінансовою й соціально-економічною кризою останніх років та військовим конфліктом на сході країни [2, c. 227].

Науковці різних сфер, як медики, так і демографи, економісти, дослідники соціальної географії, відзначають, що рівень соціальноекономічного розвитку країни, зокрема рівень зайнятості населення, рівень доходів, соціальний захист, житлові умови, рівень освіти, суттєво впливає на стан суспільного здоров'я [9, $11]$.

У свою чергу соціально-економічна система України залежить, зокрема, і від соціальнокультурних факторів.

\section{АНАЛІЗ ОСТАННІХ ДОСЛІДЖЕНЬ, У ЯКИХ ЗАПОЧАТКОВАНО ВИРІШЕННЯ ПРОБЛЕМИ}

Питання вивчення соціально-культурних факторів та їх вплив на формування сучасної соціально-економічної системи України опосередковано досліджувалися такими науковцями: М.П. Войнаренко, О.І. Гончар [2], С.В. Мочерний [4], Н.Г. Пігуль [7], Г.В. Піньковська [8], В.В. Тарасова [11], $\Lambda$.Т. Шевчук [14] та ін.

Аослідженню сутності міжкультурних відносин, факторів національної культури, які визначають способи структурування і управління організаціями, впливу національного менталітету присвятили свої праці П.М. Бал- таджи [1], О.В. Юринець, М.М. Федорів [15], В.М. Шаповал, М.С. Пашкевич, А.А. Аратвер [13], Г. Хофштеде (G. Hofstede) [16] та ін.

\section{META CTATTI}

Мета дослідження полягає у визначенні основних соціально-культурних факторів формування сучасної соціально-економічної системи України та дослідженні їх ролі й впливу на цей процес.

\section{ВИКЛАД ОСНОВНОГО МАТЕРІАЛУ ДОСЛІДЖЕННЯ 3 ПОВНИМ ОБГРУНТУВАННЯМ ОТРИМАНИХ НАУКОВИХ РЕЗУЛЬТАТІВ}

Складна соціально-економічна система "влада-бізнес-громада" містить у собі не лише економічні, демографічні, інституційні, природно-екологічні, але й соціально-культурні елементи. Хоча соціально-культурна складова $€$ відносно латентною, вона, однак, має значний вплив на систему в цілому.

Вважаємо за доцільне виділити такі групи соціально-культурних факторів формування сучасної соціально-економічної системи України (рис. 1):

- фактори соціально-побутової інфраструктури;

- фактори соціально-культурної інфраструктури;

- соціальні ресурси;

- ментальні фактори.

Автори Економічної енциклопедії за редакцією В. Мочерного у складі соціально-побутової інфраструктури розрізняють такі компоненти як житлово-комунальне господарство, побутове обслуговування населення, торгівля га громадське харчування, пасажирський транспорт і зв'язок для обслуговування населення тощо [4; 7]. У складі факторів соціальнопобутової інфраструктури нами виділені: забезпеченість населення житлом; стан житловокомунального господарства; розвиток торгівлі 


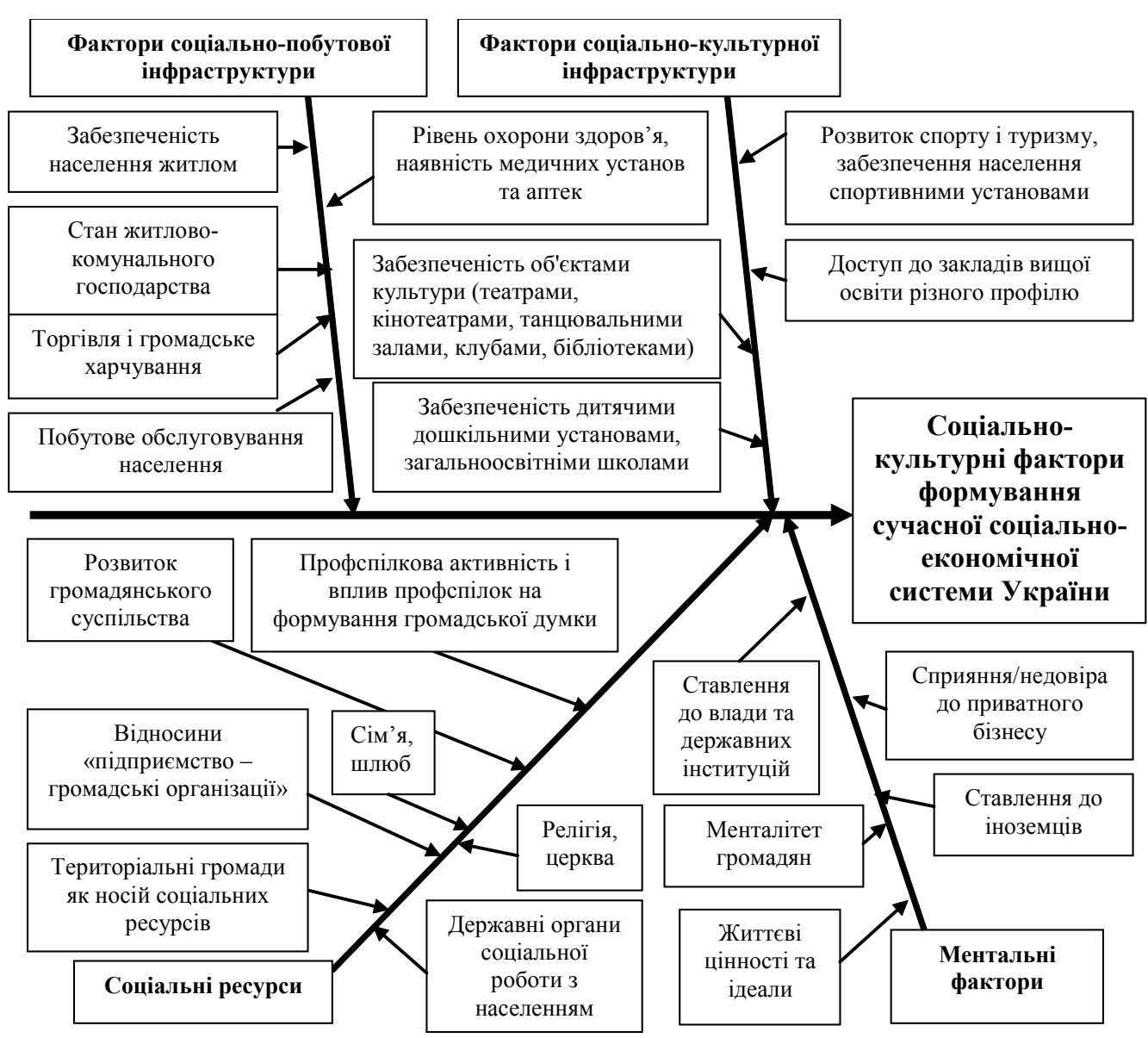

Рис. 1. Соціально-культурні фактори формування сучасної соціально-економічної системи України

Ажерело: систематизовано авторами на основі $[2 ; 4 ; 7 ; 8 ; 10 ; 11 ; 12 ; 14]$.

і громадського харчування; рівень побутового обслуговування населення; рівень охорони здоров'я, наявність медичних установ та аптек.

Рівень забезпеченості населення об'єктами соціально-побутової інфраструктури суттєво впливає на продуктивність праці (чим нижчий рівень забезпеченості, тим нижчий рівень продуктивності праці), стан здоров'я населення (наприклад, якщо забезпеченість житлом ниж-

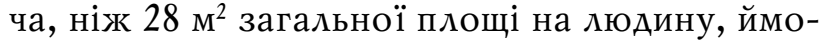
вірність захворювань населення різко зростає, що негативно позначається на функціонуванні продуктивних сил), освітній рівень населення [14].

Соціально-культурна інфраструктура охоплює охорону здоров'я, рекреаційне господарство, фізичну культуру та спорт, соціальне забезпечення, освіту, культуру та мистецтво, культові споруди тощо [4]. У складі факторів соціально-культурної інфраструктури нами виділені: забезпеченість об'єктами культури (театрами, кінотеатрами, танцювальними залами, клубами, бібліотеками); забезпеченість дитячими дошкільними установами, загальноос- вітніми школами; доступ до закладів вищої освіти різного профілю; розвиток спорту і туризму, забезпечення населення спортивними установами.

Чільне місце серед факторів соціальнокультурної інфраструктури посідає освітній рівень суспільства. Як слушно зауважує I. Титаренко, аналізуючи соціально-економічний розвиток будь-якої країни необхідно враховувати освітній рівень суспільства як одного 3 факторів впливу на різноманітні сфери громадського життя. Освіта допомагає людині гармонійно пристосуватися до сучасного життя, забезпечує свободу професійного, інтелектуального та соціального вибору. Рівень освіти визначає якість життя як суспільства в цілому, так і окремої особи зокрема [12].

На основі аналізу взаємозв'язку інфраструктурного забезпечення культурного середовища та ефективності його використання Піньковська Г.В. виділяє сім груп регіонів України за рівнем його розвитку, а саме [8]:

1. Регіони з високим рівнем ефективності використання об'єктів культури при високому 
та середньому рівні розвитку їх інфраструктури - АР Крим, Миколаӥвська, Харківська, Хмельницька, Черкаська та Чернівецька області.

2. Регіони з високим рівнем ефективності використання об'єктів культури при низькому рівні розвитку їх інфраструктури - м. Київ та м. Севастополь.

3. Регіони з середнім та нижчим за середній рівнем ефективності використання об'єктів культури при високому рівні розвитку їх інфраструктури - Вінницька та Чернігівська області.

4. Регіони з середнім рівнем ефективності використання об'єктів культури при середньому та нижчому за середній рівні розвитку їх інфраструктури - Київська та Полтавська області.

5. Регіони 3 нижчим за середній рівнем ефективності використання об'єктів культури при середньому, нижчому за середній та низькому рівні розвитку їх інфраструктури Аніпропетровська та Ауганська області.

6. Регіони з низьким рівнем ефективності використання об'єктів культури при високому та середньому рівні розвитку їх інфраструктури - Івано-Франківська, Кіровоградська, Тернопільська, Херсонська, Рівненська та Волинська області.

7. Регіони з низьким рівнем ефективності використання об'єктів культури при низькому та нижчому за середній рівні розвитку їх інфраструктури - Аонецька, Житомирська, Закарпатська, Запорізька, Мьвівська, Одеська та Сумська області.

Аослідниця робить висновок про зростання галузевої розбалансованості господарських систем культурного середовища та зниження іх взаємозалежності на регіональному рівні [8].

Окрему групу факторів представляють соціальні ресурси, які є складовою соціального капіталу. Основними суб'єктами прояву соціальних ресурсів виступають: суспільство в цілому, громадські організації, громадські рухи, тимчасові об'єднання громадян, територіальні громади, особистість та ін. [10, с. 34].

У складі соціальних ресурсів як факторів нами виділено: сім'я, шлюб; релігія, церква; розвиток громадянського суспільства; профспілкова активність і вплив профспілок на формування громадської думки; відносини "підприємство - громадські організації"; територіальні громади як носій соціальних ресурсів; державні органи соціальної роботи з населенням.

Соціальні ресурси є вагомим чинником розвитку територіальних громад, оскільки їх мобілізація та реалізація супроводжується синер- гетичним ефектом завдяки підвищенню ефективності використання всіх інших видів ресурсів: матеріальних, господарських, природних та ін. На рівні громад соціальні ресурси забезпечують перспективи їх ефективної діяльності за рахунок свідомого використання соціальних зв'язків та мереж. Вони стають засобами досягнення визначених цілей громади завдяки довірі, спільним інтересам та цілям, нормам та правилам [10, с. 35].

Ао наступної групи факторів вважаємо за доцільне віднести ментальні фактори. Менталітет - це характер та лад людського мислення, що реалізується на рівні колективної та індивідуальної свідомості, але грунтується на структурних елементах сфери підсвідомого, що включають у себе архетипи як окремої особистості, так і етносу загалом [15]. Історикофілософський підхід характеризує менталітет як духовно-інтелектуальний феномен, якому притаманна динаміка і універсальність. Предметом більшості сучасних досліджень виступає національний менталітет, як узагальнююча категорія, яка вбирає в себе зміст етнопсихологічних, так і етноідеологічних чинників, нерозривно пов'язана з історичними умовами розвитку нації і відображає зміни народних світовідчуттів [1].

Менталітет українця складався тривалий час під впливом суспільно-історичних обставин. Українці завжди були землеробською нацією. Постійний зв'язок із землею, який називають українським антеїзмом, наклав на їхню духовність відбиток психічної селянськості. Культ Землі, землеробської Праці є основою світобачення українського селянина [5].

Українці - інтроверсна нація. Поширеними рисами українського народу є замкненість, тихий норов, почуття всепрощення, підпорядкованості, терпимості, прагнення до духовного усамітнення, певний життєвий аскетизм, невибагливість. Українця характеризує також висока чуттєвість, домінування почуттєвого над інтелектуальним і вольовим [5].

Аля українців важливі дохід, успіх у конкурентній боротьбі рівною мірою як і дружелюбна атмосфера, стабільність становища, солідарність. Землеробська культура, залишки матріархату зумовили активну, пріоритетну роль жінки в сім'ї. Водночас активність, волелюбність і демократизм, пріоритет чоловіка почали фіксуватися і закріплюватися в українській ментальності за часів існування Запорозької Січі [15].

Значною мірою негативно на національний менталітет вплинула довготривала відсутність 
власної держави. Здійснювані протягом століть цілеспрямоване знищення та денаціоналізація української еліти надзвичайно звужували коло політичних лідерів народу. В результаті, з одного боку, посилилась консервативність національного характеру як засобу захисту своїх традицій та цінностей від зовнішніх чинників, а 3 іншого - поглибилась недовіра народу до власної еліти [3].

Загалом українця можна охарактеризувати такими рисами, як адаптивність, гнучкість, гостинність і товариськість, приземлений прагматизм, розвинена інтуїція, працьовитість, хазяйновитість, універсальність, широкий кругозір, жвавість, нестандартні ходи, креативність, що є обов'язковою передумовою інноваційної активності співробітників [15].

Менталітету українських працівників та менеджерів притаманна певна двоїстість та парадоксальність:

- 3 одного боку - креативність, з іншого консерватизм і опір змінам ("Хай хоч би як, аби не гірше");

— з одного боку - схильність до анархї̈ ("в душі кожного українця живе махновець"), 3 іншого боку - Російська та Австрійська імперії багаторазово рекрутували для себе в Україні науковців, чиновників та офіцерів (канцлер О.А. Безбородько, генерал-фельдмаршал І.Ф. Паскевич, письменник, громадський діяч I.П. Котляревський та ін.);

- 3 одного боку - прагнення до спокою та стабільності, певною мірою навіть байдужість ("моя хата з краю"), з іншого - активна участь громадян у суспільно-політичному житті країни, відстоювання своєї позиції, поширення різного роду волонтерських рухів;

- прагнення применшувати перед оточуючими свої досягнення та доходи ("аби не заздрили"), що абсолютно не відповідає принципам людини "західного" типу, з її орієнтацією на успіх.

Реалії сучасного світу вносять свої корективи до менталітету українських працівників, цьому сприяють:

- вплив західної культури і ментальності (частина громадян побувала в країнах Заходу і отримала новий досвід);

- вплив всесвітньої інформаційної мережі "Інтернет", 3МI, соціальних мереж, які мають значний вплив на ментальність української молоді і часто пропагують західний стиль поведінки (наприклад, прагнення досягти успіху, побудувати кар'єру, слідування так званій "американській мрії").

Водночас ментальність значної частини громадян, переважно старшого віку, несе відбиток радянського менталітету, що складався протягом семи десятиліть на усій території СРСР незалежно від національної приналежності. Ï̈і головними рисами є опір змінам, пасивність, безініціативність, бажання мати над собою сильного лідера, вислужитись перед керівництвом, завищені очікування від нього, комплекс меншовартості, в роботі - "зрівнялівка", вдавана діяльність, надія на зовнішню допомогу ("керівник завжди правий", "як би чого не вийшло...").

Відомий нідерландський соціолог Герт Хофштеде (нідерл. Geert Hofstede) на основі досліджень, проведених у 60-тих - 70-тих роках XX ст. запропонував сукупність показників (індексів), що визначають культурні характеристики різних народів [16]:

- дистанція влади (PDI), індекс, який визначає ступінь сприйняття влади у суспільстві, очікування суспільства, інституцій, організацій від влади, рівень дистанційності культур від влади;

- мужність (MAS), індекс, який визначає ступінь націлення суспільства на досягнення результату будь-якою ціною. Аля країн "чоловічого типу" характерні такі якості як суперництво, впевненість у собі, цілеспрямованість, перевага матеріальним цінностям. Аля країн "жіночого типу" характерні шанування взаємовідносин, культурних цінностей, турбота про якість життя;

- уникнення невизначеності (UAI), індекс, що визначає ступінь сприйняття і реагування суспільства на невідомі ситуації;

- довготермінова орієнтація (LTO), індекс, що демонструє короткострокову або довгострокову орієнтацію на майбутнє, орієнтованість на вирішення стратегічних, довгострокових цілей, бажання передбачати майбутнє;

- допущення (IVR), індекс, який представляє собою ступінь щастя суспільства та задоволення життям людей.

У дослідженнях А. Панченко [6], а також О.В. Юринець та М.М. Федоріва [15] було визначено числове значення чотирьох індексів Хофштеде для української культури. Аослідження, проведені на базі спільного українськоамериканського підприємства показали, що величина таких змінних, як "Аистанція влади" i "Уникнення невизначеності" в Україні приблизно вдвічі перевищує середні значення, а характеристика індивідуалізму набагато нижча від середнього рівня. Числове значення такої змінної, як "Мужність" не набагато перевищує середній показник за результатами Хофштеде [6]. 
Ці результати в цілому підтверджують вище сформульовані особливості українців. Високий показник дистанції влади демонструє поки що значний відрив влади від народу, небажання керівництва взаємодіяти 3 підлеглими на рівних, переважання автократичного стилю керівництва, що, безумовно, є негативним пережитком радянського минулого. Високе значення індексу "Уникнення невизначеності" свідчить про значний ступінь невпевненості українців у майбутньому, що пояснюється непростими умовами перехідного періоду, нестабільністю економічної та політичної ситуації в країні.

Можна цілком погодитись із твердженням B.М. Шаповала, М.С. Пашкевича та А.А.Аратвера про те, що світосприйняття середньостатистичного українця стало симбіозом західної, радянської та української культури [13].

Наведені ментальні особливості українців мають велике значення для розуміння особливостей управління відносинами в соціальноекономічній системі "влада - бізнес - громада", зокрема їх ролі у становленні громадянського суспільства, у відносинах з бізнесом і ставленні до влади. Беззаперечними перевагами української ментальності, в цьому контексті, $є$ працьовитість та хазяйновитість, доброзичливість та толерантність до інших національностей, гнучкість та адаптивність до змін. Певною мірою цьому сприятиме поступовий відхід від радянської ментальності, викликаний зміною поколінь та зростанням впливу західної культури та традицій.

\section{ВИСНОВКИ 3 ПРОВЕДЕНОГО ДОСЛІДЖЕННЯ I ПЕРСПЕКТИВИ ПОДАЛЬШИХ РОЗВІДОК У ДАНОМУ НАПРЯMI}

Таким чином, можна констатувати, що соціально-культурні фактори мають значний вплив на формування соціально-економічної системи "влада - бізнес - громада". Вважаємо, що найбільш вагомими групами соціальнокультурних факторів $є$ фактори соціально-побутової інфраструктури, фактори соціальнокультурної інфраструктури, соціальні ресурси, а також ментальні фактори.

Фактори соціально-побутової інфраструктури та соціально-культурної інфраструктури підвищують привабливість регіону для жителів та інвесторів. Їх сукупна дія здійснює позитивний вплив на різноманітні сфери громадського життя.

Соціальні ресурси виступають важливим чинником розвитку територіальних громад, головним чином як вагомий інструмент і складова потенціалу громадянського суспільства.

Ментальні фактори є важливим чинником впливу на формування сучасної соціально-економічної системи України. Беззаперечними перевагами українців, викликаних їх ментальними особливостями, є працьовитість та хазяйновитість, доброзичливість та толерантність до інших національностей, гнучкість та адаптивність до змін. Водночас у подальшому варто позбутися таких слабких сторін, викликаних ментальними особливостями, як відсутність ініціативи, відсутність здорових амбіцій, дистанціювання від особистої відповідальності, надія на зовнішню допомогу.

Аослідження впливу соціально-культурних факторів на формування соціально-економічної системи "влада-бізнес-громада" в Україні є досить актуальним. Перспективним $€$ також дослідження їх впливу у взаємодії з іншими факторами.

\section{$\Lambda$ ітература:}

1. Балтаджи П.М. Поняття "ментальність" у сучасних наукових дослідженнях. Актуальні проблеми політики. 2012.№ 45. URL: http://app.onua.edu.ua/index.php/app/article/view/870/838

2. Войнаренко М., Гончар О. Трансформація соціально-економічних систем за умов інтеграційних перетворень. Журнал європейської економіки. 2018. Т. 17, № 2. С. 225-243.

3. Аовідник з історії України (А-Я): посіб. Аля сер. загальноосвітн. навч. закл. / за заг. ред. I. Підкови, Р. Шаста. 2-ге вид., доопр. і доповн. Київ: Генеза, 2001. 1136 с.

4. Економічна енциклопедія: У трьох томах. Т. 1 / Редкол.: С.В. Мочерний (відп. ред.) та ін. Київ: Видавничий центр "Академія", 2000. 864 с.

5. Колодний А.М., Филипович $\Lambda$.О. Релігійна духовність українців: вияви, постаті, стан.

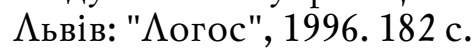

6. Панченко А., Тихомирова И. Украина в системе культурных координат бизнеса. Менеджмент и менеджер. 2002. № 8. С. 15-19.

7. Пігуль Н.Г. Соціальна інфраструктура: функціональне призначення та особливості розвитку. Економічний аналіз: зб. наук. праць. Тернопільський національний економічний університет; редкол.: В.А. Аерій (голов. ред. ) та ін. Тернопіль: Видавничо-поліграфічний центр Тернопільського національного економічного університету "Економічна думка". 2014. Т. 16. № 1. С. $117-122$.

8. Піньковська Г.В. Оцінка сучасного стану розвитку культурного середовища регіонів України. Ефективна економіка. 2014. № 10. URL: http://nbuv.gov.ua/UJRN/efek_2014_10_36 
9. Смик О.С. Вплив соціально-економічних умов на стан здоров'я населення. Вчені записки Таврійського національного університету імені В.I. Вернадського. Серія "Географія". Сімферополь. Т. 10. Вип. 2. 2014. С. 239-242.

10. Соціальні ресурси децентралізації управління: механізми мобілізації та ефективного використання / О.Ф. Новікова, О.І. Амоша, В.П. Антонюк, В.П. Вишневський та ін.; НАН України, Ін-т економіки пром-сті. Київ, 2018. $480 \mathrm{c}$.

11. Тарасова В.В. Взаємовідносини суспільства і довкілля в регіональних соціально-економічних умовах. Бізнес Інформ. 2013. № 7. C. 54-60. URL: http://nbuv.gov.ua/UJRN/binf_$2013 \quad 7 \quad 10$

12. Т итаренко I.O. Освітологічний контекст поняття "соціально-культурні чинники". Освітологічний дискурс. 2017. № 1-2 (16-17). С. 2327.

13. Шаповал B.M., Пашкевич M.С., Аратвер А.А. Вплив менталітету нації на характер мотивації праці на українських підприємствах. Економічний простір. 2012. № 68. С. 282-289.

14. Шевчук $\Lambda . Т$. Регіональна економіка: навчальний посібник: рек. МОНУ. Київ: Знання, 2011. 319 c.

15. Юринець О.В., Федорів М.М. Аналіз впливу національного менталітету на формування організаційної культури. Соц.-екон. дослідж. в перехід. період. 2007. Вип. 6. С. 206-214.

16. Hofstede G. Culture's Consequences, Comparing Values, Behaviors, Institutions, and Organizations Across Nations. Thousand Oaks CA: Sage Publications, 2001.

\section{References:}

1. Baltadzhy', P.M. (2012), "The concept of "mentality" in modern scientific research", Aktual'ni problemy' polity'ky', vol. 45, Available at: http://app.onua.edu.ua/index.php/app/ article/view/870/838 (accessed 10 October 2021).

2. Vojnarenko, M. and Gonchar, O. (2018), "Transformation of social and economic systems for the minds of integrated re-creation", Zhurnal yevropejs'koyi ekonomiky', vol. 17, no. 2, pp. 225-243.

3. Pidkova, I. and Shast, R. (2001), Dovidny'k z istoriyi Ukrayiny' (A-Ya) [Handbook of Ukrainian History (A-Z)], Geneza, Kyiv, Ukraine.

4. Mocherny'j, S.V. (2000), Ekonomichna ency'klopediya: U tr'ox tomax. [Economic Encyclopedia: In three volumes], vol. $1, V^{\prime}$ 'davny'chy'j centr "Akademiya", Kyiv, Ukraine.

5. Kolodny'j, A.M. and Fy'ly'povy'ch, L.O. (1996), Religijna duxovnist' ukrayinciv: vy'yavy', postati, stan [Religious spirituality of Ukrainians: manifestations, figures, state], Logos, L'viv, Ukraine.

6. Panchenko, A. and Tihomirova, I. (2002), "Ukraine in the system of cultural coordinates of business", Menedzhment i menedzher, vol. 8, pp. 15-19.

7. Pigul', N.G. (2014), "Social infrastructure: functional purpose and features of development", Ekonomichny'j analiz: zb. nauk. pracz'. Ternopil's'ky'j nacional'ny'j ekonomichny'j universy'tet, vol. 16 , no. 1 , pp. $117-122$.

8. Pin'kovs'ka, G.V. (2014), "Assessment of the current state of development of the cultural environment of the regions of Ukraine", Efekty'vna ekonomika, vol. 10, Available at: http:// nbuv.gov.ua/UJRN/efek_2014_10_36 (accessed 25 October 2021).

9. Smy'k, O.S. (2014), "Influence of social and economic conditions on the state of health of the population", Vcheni zapy'sky' Tavrijs'kogo nacional'nogo universy'tetu imeni V.I. Vernads'kogo. Seriya "Geografiya", vol. 10, no. 2, pp. 239-242.

10. Novikova, O.F., Amosha, O.I., Antonyuk, V.P. and Vy'shnevs'ky'j, V.P. (2018), Social'ni resursy' decentralizaciyi upravlinnya: mexanizmy' mobilizaciyi ta efekty'vnogo vy'kory'stannya [Social resources of decentralization of management: mechanisms of mobilization and effective use], NAN Ukrayiny', Insty'tut ekonomiky' promy'slovosti, Kyiv, Ukraine.

11. Tarasova, V.V. (2013), "Relationships between society and the environment in regional socio-economic conditions", Biznes Inform, vol. 7, pp. 54-60, Available at: http://nbuv.gov.ua/ UJRN/binf_2013_7_10 (accessed 27 October 2021).

12. Ty'tarenko, I.O. (2017), "Educational context of the concept of "socio-cultural factors", Osvitologichny'j dy'skurs, vol. 1-2 (16-17), pp. 23-27.

13. Shapoval, V.M., Pashkevy'ch, M.S. and Dratver, D.A. (2012), "The influence of the nation's mentality on the nature of work motivation in Ukrainian enterprises", Ekonomichny'j prostir, vol. 68, pp. 282-289.

14. Shevchuk, L.T. (2011), Regional'na ekonomika: navchal'ny'j posibny'k [Regional economics: textbook], Znannya, Kyiv, Ukraine.

15. Yury'necz', O. V. and Fedoriv, M. M. (2007), "Analysis of the influence of the national mentality on the formation of organizational culture", Socz.-ekon. doslidzh. v perexid. period, vol. 6, pp. 206-214.

16. Hofstede, G. (2001), Culture's Consequences: Comparing Values, Behaviors, Institutions, and Organizations. Across Nations, 2nd ed., Sage, Thousand Oaks, CA.

Стаття надійшла до редакцї 04.01.2022 p. 
УAK 339.138.01 (075.8)

В. В. Макарова,

А. е. н., доцент, доцент кафедри маркетингу та догістики,

Сумський національний аграрний університет

ORCID ID: 0000-0003-1076-9246

B. А. Муштай,

к. е. н., доцент, доцент кафедри маркетингу та логістики,

Сумський національний аграрний університет

ORCID ID: 0000-0001-9042-0241

DOI: $10.32702 / 2306-6792.2022 .1 .20$

\title{
ІНСАЙТ-ТЕХНОЛОГІЯ ПРИ ФОРМУВАННІ КУПІВЕАЬНОЇ ПОВЕАІНКИ СПОЖИВАЧІВ В УМОВАХ ЗАПРОВААЖЕННЯ МАРКЕТИНГУ BIAНОСИН
}

\author{
V. Makarova, \\ Doctor of Economic Sciences, Associate Professor, Associate Professor of the Department \\ of Marketing and Logistics, Sumy National Agrarian University \\ V. Mushtay, \\ $\mathrm{PhD}$ in Economics, Associate Professor, Associate Professor of the Department \\ of Marketing and Logistics, Sumy National Agrarian University
}

\section{INSIGHT TECHNOLOGY IN THE FORMATION OF CONSUMER CONSUMPTION BEHAVIOR IN CONDITIONS OF RELATIONSHIP MARKETING}

У статті розглянуто семантику понять "психологічний інсайт" і "споживчий інсайт" та надані пояснення щодо їх категоріальної спорідненості і відмінності. За траєкторією досліджень обгрунтовано доцільність використання інсайт технології у маркетинговій діяльності як з позиції фахової компетентності маркетологів, так і в площині купівельної поведінки реальних споживачів на ринку товарів і послуг. Розглянуто порівняльну характеристику контентів психологічного та споживчого інсайтів у контексті купівельної поведінки кінцевих покупців товарної продукції. ПреАставлено модель тривалості прийняття рішення окремим суб'єктом в умовах традиційного проваАження заходів купівлі-продажу та за обставин реалізації інсайт технології в контексті формування концепції маркетингу відносин. Встановлено умови прояву споживчого інсайту у ординарних покупців на Аинамічно-мінливому ринку товарів і послуг.

The article deals with the essence of the definitions of "psychological insight" and "consumer insight", provides explanations for their categorical relatedness and differences. The authors emphasize that the phenomenon of insight is directly related to the consumer, but the procedure of forming a motivational attitude for the consumer is a priority for the marketer. The expediency of using insight technology in marketing activities was substantiated both from the standpoint of professional competence of marketers and in terms of purchasing behavior of real consumers in the market of goods and services.

The article also compares the content of psychological and consumer insights in the context of purchasing behavior of end buyers of marketable products. The authors provide their own definition of consumer insight technology, which is a set of interrelated marketing activities that allow consumers to spontaneously have a motive to buy when solving personal purchasing problems. The main advantage of using consumer insight technology is not only that it provides a marketing hint or motivation to the consumer, but also that it reduces the time required by the consumer to make a 
decision to take a purchase. The authors present a model of the duration of decision-making by an individual entity in the traditional implementation of sales activities and in the circumstances of the implementation of insight technology in the context of forming the concept of relationship marketing. The authors also proposed the use of the coefficient of efficiency of consumer insight technology and substantiated the methodology for its determination.

The authors conclude that the knowledge of the marketer's insight psychology of the end consumer should have a productive effect on his purchasing behavior in terms of making subconscious decisions to purchase goods or services. This scenario is extremely relevant in today's environment, when the product and information market is extremely oversaturated and the effectiveness of marketing activities is significantly reduced. It is substantiated that only enterprises that will be able to extensively research and study the mechanisms of consumer motivation will hope to expand sales and make a profit.

Ключові слова: інсайт-технологія, споживчй інсайт, психологічний інсайт, поведінкаспоживачів, маркетинг відносин.

Key words: insight technology, consumer insight, psychological insight, consumer bebavior, relationship marketing.

\section{ПОСТАНОВКА ПРОБЛЕМИ У ЗАГАЛЬНОМУ ВИГЛЯДІ ТА ІІЇ ЗВ'ЯЗОК ІЗ ВАЖЛИВИМИ НАУКОВИМИ ЧИ ПРАКТИЧНИМИ \\ ЗАВДАННЯМИ}

3 кожним роком національні бізнес-утворення намагаються збільшити власний прибуток завдяки розширенню як асортименту продукції, так і кількісних об'ємів її випуску. Така стратегія розвитку неодмінно призводить до проблем, пов'язаних із необхідністю активізації процедури реалізації товарів та послуг на внутрішніх і зовнішніх споживчих ринках, а тим самим з розробкою нових механізмів, практик та прийомів маркетингової стратегії і тактики.

В умовах ускладнення маркетингових комунікацій, які мають результативно ув'язувати попит і пропозицію, виявляти існуючі уподобання споживачів товарів і послуг, розробляти новітні формати маркетингового впливу на емоційний настрій покупців, саме інноваційні маркетингові технології є чи не єдиним інструментом, який ефективно налаштовує споживача до здійснення купівельних дій.Ао цього виду маркетингових інновацій можна віднести й технологію інсайту, тобто певної сукупності послідовних комунікативних операцій, спрямованих на пробудження у потенційного споживача мимовільного бажання придбати конкретний товар або отримати запропоновану послугу. У такий спосіб в умовах швидкозмінного ринку товарів і послуг формується новий вид маркетингової комунікації, що стимулює й спрямовує набувача товарної продукції за визначеною траєкторією купівельної дії з відносно нетривалим строком прийняття рішення окремим споживачем на ринку купівлі-продажу товарів і послуг різновидового попиту.

\section{АНАЛІЗ ОСНОВНИХ ДОСЛІДЖЕНЬ І ПУБЛІКАЦІЙ}

На початковому етапі феномен інсайту активно вивчали зарубіжні науковці: Едвард де Боно, Вільям Гордон, Макс Вертгеймер, Ажо Гілфорд, Карл Аункер, Курт Коффка, Вольфганг Кьолер, Алекс Осборн, Елліс Торранс, Фріц Цвіккі, Мігай Чиксентмігаї та інші. За своїм фаховим спрямуванням більшість із них були психологами, а отже, і їх теоретичні розробки прикладалися до причин виникнення цього явища і процедури його проходження, не вдаючись до глибинного вивчення наслідкових проявів означеного феномену у провідних сферах соціокультурного простору: законодавчій, виробничій, освітній, науковій, творчій, інформаційній, торгівельній та інших.

В організації вітчизняної науки проблематику інсайту досліджували: у сфері наукового інсайту - О.В. Губенко, О.В. Крушельницька; у сфері творчого інсайту - Н.А. Карпенко, В.В. Клименко, В.О. Моляко, В.В. Рибалка, О.А. Туриніна; у сфері педагогічного інсайту P.С. Гуревич, С.О. Сисоєва, О.І. Пометун, Т.О. Пушкарьова, Н.В. Ханецька, у сфері споживчого інсайту - С.М. Ілляшенко, Ю.Т. Процишин, С.Є. Хрупович, І.А. Решетнікова тощо. Водночас роботи представлених авторів 3 проблеми запровадження технології інсайту є на сьогодні нечисленними й такими, що недостатньо розкривають як особливості урахування причин виникнення означеного феномену за умови провадження суспільно значущої діяльності, так само і специфічність наслідкових ефектів (позитивних чи-то негативних), які виникають у результаті прояву інсайту у суб'єкта 
Таблиця 1. Порівняння психологічного і споживчого контентів інсайту

\begin{tabular}{|c|c|}
\hline \multicolumn{2}{|c|}{ Детерміновані контенти інсайту } \\
\hline Психологічний контент & Споживчий контент \\
\hline $\begin{array}{l}\text { Осяяння - } \\
\text { неконтрольований свідомістю людини акт, } \\
\text { який характеризує короткочасний момент } \\
\text { відкриття істини чи прийняття рішення } \\
\end{array}$ & $\begin{array}{l}\text { Збагнення - } \\
\text { підсвідомий, короткотривалий поштовх до } \\
\text { здійснення якогось вчинку, пов’язаного із } \\
\text { задоволенням певного бажання покупця } \\
\end{array}$ \\
\hline $\begin{array}{l}\text { Інтуїція - } \\
\text { безпосереднє сприйняття, осягнення } \\
\text { сутності без допомоги ранішнього досвіду, } \\
\text { тривалих логічних розмірковувань або } \\
\text { доказів }\end{array}$ & $\begin{array}{l}\text { Передчуття - } \\
\text { здатність людини за утворених обставин } \\
\text { несвідомо, за участі лише «шостого чуття», } \\
\text { автоматично виконувати купівельні дії }\end{array}$ \\
\hline $\begin{array}{l}\text { Вгадування - } \\
\text { здібність людини інтуїтивно } \\
\text { здогадуватися про щось або робити } \\
\text { прогностичні висновки у відношенні до } \\
\text { чогось на основі почуттів }\end{array}$ & $\begin{array}{l}\text { Розпізнання - } \\
\text { звичка потенційного покупця розрізняти та } \\
\text { сприймати органами чуття потребу } \\
\text { стосовно здійснення обмінної операції }\end{array}$ \\
\hline $\begin{array}{l}\text { Усвідомлення - } \\
\text { навичка індивіда осмислювати } \\
\text { необхідність вчинення певної акції та } \\
\text { знаходження сенс у провадженні такої } \\
\text { поведінкової траєкторії }\end{array}$ & $\begin{array}{l}\text { Осягнення - } \\
\text { усвідомлення окремо визначеним суб'єктом } \\
\text { правильності своїх бажань у відношенні до } \\
\text { фактичного придбання омріяного товару }\end{array}$ \\
\hline $\begin{array}{l}\text { Фантазія - } \\
\text { абсолютно нічим не обгрунтована вигадка } \\
\text { про те, що нині існує тільки в уяві, але не в } \\
\text { реалістичній дійсності }\end{array}$ & $\begin{array}{l}\text { Здогадування - } \\
\text { несподівано народжена думка стосовно } \\
\text { речі, що не перебуває у арсеналі особи, але } \\
\text { яка наразі є омріяною, очікуваною і } \\
\text { жаданою }\end{array}$ \\
\hline $\begin{array}{l}\text { Уява - } \\
\text { здатність певної особистості відтворювати } \\
\text { чи-то формувати у думках конструктивні } \\
\text { та яскраві образи на основі чуттєвого } \\
\text { досвіду }\end{array}$ & $\begin{array}{l}\text { Передбачення - } \\
\text { особистісний інструментарій здогадування } \\
\text { про конструктивну перспективність якоїсь } \\
\text { виконуваної дії або здійснюваного вчинку }\end{array}$ \\
\hline $\begin{array}{l}\text { Піднесення - } \\
\text { перебування особи у радісному, } \\
\text { зачарованому стані задоволення та } \\
\text { замилування життя у цілому або якимось } \\
\text { предметами зокрема }\end{array}$ & $\begin{array}{l}\text { Захоплення - } \\
\text { відчуття незвичного інтересу та потягу до } \\
\text { якогось товарно-речового об'єкту, що має, } \\
\text { за певних умов, усі шанси бути придбаним }\end{array}$ \\
\hline $\begin{array}{l}\text { Конструювання - } \\
\text { уміння індивіда розробляти, поєднувати, } \\
\text { аналізувати, формувати та організовувати } \\
\text { щось нове із чогось відомого та звичного }\end{array}$ & $\begin{array}{l}\text { Експериментування - } \\
\text { винаходження нових, неординарних рішень } \\
\text { при облаштуванні життєвого простору за } \\
\text { допомогою новітніх технологій та речей }\end{array}$ \\
\hline
\end{tabular}

певного завдання чи проблеми $[1$, с. 306]. У свою чергу лексему "споживчий" доцільно тлумачити як такий, що має слугувати вирішенню нагальних проблем споживачів і задоволенню їх повсякденних потреб у товарах та послугах на відповідних ринках [2, c. 559].

У такий спосіб споживчий інсайт $є$ актуальним сприймати як психологічний феномен, що являє собою холістичне (цілісне) комплексне) сприйняття проблеми задоволення сьогочасних потреб споживача, на одному із етапів розв'язання якої у споживача мимовільно формується уява щодо її вирішення і з'являється мотив для здійснення купівельної акції на ринку товарів чи послуг. При цьому саме явище інсайту має безпосереднє відношення до споживача, як суб'єкта товарного ринку, а ось процедура формування мотиваційної установки для споживача, як варіанта $з$ розв'язання його проблеми, є фаховим завданням маркетолога. На підтвердження цього підходу доречно привести думку Філіпа Котлера, який стверджував, що маркетинг складається з дій, запроваджуваних в річищі того, аби домага-

по відношенню до певного предмета або явища.

\section{META CTATTI}

Метою статті $€$ дослідження та аналіз науково-методологічних підходів до сутності споживчого інсайту, виокремлення особливостей та переваг застосування технології споживчого інсайту, що дозволить масштабувати об'єми товарообороту, а також сприятиме налаштуванню емоційно-асоціативного взаємозв'язку між споживачем і товаром чи послугою в умовах формування маркетингу відносин.

\section{ВИКЛАД ОСНОВНОГО МАТЕРІАЛУ ДОСЛІДЖЕННЯ}

За тлумаченням словникового ресурсу "інсайт" (англ. insight) - це психологічний феномен, який $є$ результатом несвідомої розумової діяльності людини і супроводжується раптовим осяянням: здогадкою щодо вирішення тися у будь-якій формі бажаної зворотної реакції з боку цільової споживчої аудиторії у відношенні до об'єкта, послуги або ідеї [3, с. 27]. Зі свого боку бажана зворотна реакція суттєво залежить від ціннісної оцінки суб'єктом товару, а також від його внутрішнього (психологічного) стану, який так чи інакше здійснює вплив на умотивованість суб'єктних купівельних акцій на ринку товарів і послуг.

Таким чином, споживчий інсайт є не тільки співвідносним із психологічним інсайтом, він безпосередньо зумовлюється ознаками психологічного інсайту. Між тим деякі автори розділяють категоріальну сутність психологічного й споживчого контентів інсайту, ставлячи акцент на тому, що психологічний інсайт - це буцімто якесь віртуальне явище, що має детерміноване відношення до проблем психології чи психіатрії, а от споживчий інсайт - то вже ефективна маркетингова техніка, що дозволяє впливати на реальні обсяги продажів товарів 
або послуг. Остання думка здебільшого притаманна співробітникам маркетингових компаній і цілковито має право на життя за урахування того положення, що із самого початку основним завданням маркетингу мав бути не збут товарів чи послуг, а, навпаки, головною метою маркетингу, за бачення Пітера Арукера, мала стати мінімізація зусиль по збуту продукції. У такий спосіб на провідну роль у маркетинговій діяльності виступає завдання так добре взнати і зрозуміти нагальні вимоги, запити і потреби споживачів, щоби через задоволення цих викликів зробити так, аби товар чи послуга напевно підходили споживачу і за результатом продавали самі себе [4], [3, с. 2]. Отже, найактуальнішим мотивом як бізнесу, так і маркетологів, є завдання "створення споживача" [5, c. 37], тобто знаходження суб'єктів товарного ринку, розпізнання їх емоційних уподобань, ідентифікація їхніх запитів та задоволення потреб.

Застосовуючи метод подібності у ході порівняння психологічного і споживчого контентів інсайту, маємо виокремити ключові складники досліджуваних інсайтів (табл. 1), провести їх співставлення і, на основі експертних оцінок співвідносності змісту складників інсайтів у кожній з пар порівняння, виявити відносні показники їх подібності або розбіжності в інтервалі від $0 \%$ до $100 \%$.

За результати експертного оцінювання констатуємо, що коефіцієнт конкордації становить 0,78 , що підтверджує високий рівень узгодженості експертних оцінок і дає можливість констатувати спорідненість контентів психологічного і споживчого інсайтів на рівні: осяяння/ збагнення $-88 \%$, інтуїція/передчуття - 91\%, вгадування/ розпізнання - 96\%, усвідомлення/ осягнення - 89\%, фантазія/здогадування $88 \%$, уява/передбачення $-84 \%$, піднесення/ захоплення - $82 \%$, конструювання/експериментування - 94\%. Як висновок відмітимо відносну подібність контентів психологічного та споживчого інсайтів на усередненому рівні $89 \%$. Між тим є логічним, що метод подібності не $є$ абсолютно об'єктивним, але набуті за його застосування результати можуть бути використані для якісної характеристики означених об'єктів чи явищ. Отже, метод подібності, задіяний у цьому дослідженні, навіть без виявлення чітко формалізованих параметрів надає можливість сформувати певні судження і передбачення.

Розглядаючи категоріальну сутність дефініції "технологія споживчого інсайту", сприймаємо поняття "технологія" як сполучення зв'язаних поміж собою акцій чи операцій в процесі формування або перетворення чогонебудь [6, с. 106]. У цей спосіб технологія $\epsilon$ інструментом запровадження сучасних механізмів і акцій в окресленій сфері суспільного життя, що завбачує отримання прогресивних змін та одержання стимулюючих кінцевих результатів.

За наведеним технологія споживчого інсайту завбачує сукупність ув'язаних поміж собою маркетингових заходів, завдячуючи яким у суб'єктів товарного ринку (споживачів) при розв'язанні особистих купівельних проблем мимовільно виникає мотив для здійснення операції обміну на ринку товарів або послуг. Під сукупністю маркетингових заходів у цій траєкторії маємо розуміти своєрідні фахові "підказки" чи-то мотиваційні установки (ATL реклама, поліграфічна продукція, маркетингові звернення, jingle, product placement, digital, internetproduction), які коригують і спрямовують купівельну поведінку можливого споживача, надаючи йому варіант або варіанти вирішення важливої у суб'єктному вимірі проблеми.

Безпосередньо технологія споживчого інсайту є технологією форматування купівельної поведінки ймовірного споживача, яка грунтується на психологічному явищі інсайту - мимовільному прийняттю рішення суб'єктом, що базується не на свідомому аналізі фактичних реалій, а на підсвідомому, інтуїтивному бажанні, яке сформувалося під впливом емоційно-психологічного складника, активізованого за допомогою проведених маркетингових заходів, та реалізація якого нині видається суб'єктові найбільш правильним кроком.

Застосування технології споживчого інсайту, як і будь-якої іншої технології, вимагає присутності якісної професійної підтримки, що потребує від маркетологів творчого, креативного підходу до налагодження ринково-споживчих комунікацій. Клаус Мозер з цього приводу зауважував, що коливання попиту напряму залежать від якісного характеру маркетингової політики, адже за наявності у маркетолога "таланту до продажів", останній здатен спокійно збувати "холодильники на Аляску". Це завбачує пошук таких особистостей і їх залучення до комунікації з кінцевими споживачами, мотивуючи їх через застосування технік і прийомів психодіагностичного характеру [7, c. 44-45].

Графічна інтерпретація (рис. 1) представлених вище положень та міркувань завбачує формування системної зв'язки трьох "П": пробле- 
Виявлення побажань, пріоритетів та намагань споживачів з метою проєктування і фактичного запровадження маркетологами купівельних дій

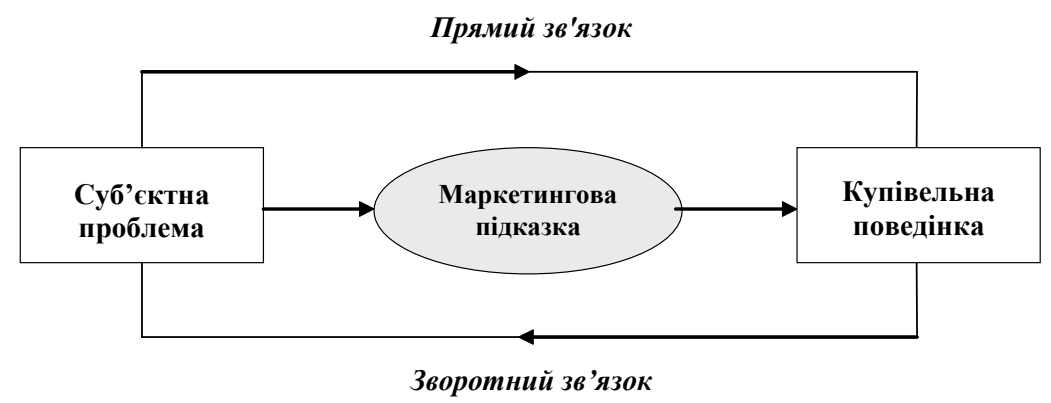

Включення суб'єктів до реєстру постійних клієнтів із наданням їм акційних знижок, маркетингових повідомлень та інших привілей з метою купівельної мотивації

Рис. 1. Графічна інтерпретація провадження технології споживчого інсайту

Ажерело: власна розробка авторів.

ма - підказка - поведінка. Водночас з позиції маркетингу "проблема" споживача має стати "завданням" для маркетологів, а її вирішення завдяки мотивації купівельної поведінки споживача є результатом маркетингової діяльності. Оскільки термін "технологія" має у своєму арсеналі дві частини: техно... (від грець. майстерність) [8, с. 824] та логос... (від грецьк. поняття, судження, зміст) [8, с. 498], є доречним визначити, що метою будь-якої технології є здійснення переходу від "завдання" до "результату". Такий підхід співпадає з баченнями Метью $\Lambda$ ібермана, який вважає, що інсайт технологія - це такий процес, за посередництвом якого суб'єкт осягає логічний зв'язок між завданням та результатом [9; 10, с. 483]. Центральне місце у цій технології займають фахові підказки чи-то мотиваційні установки, що застосовуються під час провадження маркетингових заходів.

Представлена на рисунку 1 системна конструкція складається із взаємозв'язаних компонент: входу (проблема, завдання), перетворювача (маркетингова підказка, мотиваційна установка), виходу (поведінка, рішення), ліній прямого й зворотного зв'язку. При цьому за траєкторією прямого зв'язку проходить виявлення бажань і намагань суб'єктів споживчих ринків товарів та послуг з причини проєктування й фактичного запровадження маркетологами купівельних акцій, тоді як у траєкторії зворотного зв'язку може мати ціллю включення активних споживачів до реєстру постійних клієнтів 3 наданням їм постійних знижок, а так само й інших привілей з метою активізації їх купівельної поведінки.

Більш обгрунтоване тлумачення представленої системної конструкції можна навести за аналізу положень теорії комунікацій Мелвіна Аефлера $[11 ; 12$, с. 82], у яких системна конструкція передбачає розробку "завдання" "ініціатором", відбір "технології" задля виконання даного "завдання", отримання певного "результату" і його оцінювання за допомогою каналу зворотного зв'язку із залученням фахових експертів у означеній соціокультурній сфері. У такий спосіб технологія споживчого інсайту не тільки надає маркетингову підказку або мотиваційну установку споживачеві, вона зменшує термін прийняття споживачем рішення щодо провадження купівельної дії. На рисунку 2 представлено модель тривалості прийняття рішення потенційним споживачем на ринку товарів і послуг за версіями: А) обмінної процедури із запровадженням прийомів і практик технології інсайту; В) традиційної обмінної процедури.

Експертиза порівняльної моделі тривалості прийняття рішення споживачем надає можливість визначити дельта-період $\left(\Delta T=T_{B}-\right.$ $T_{A}$ ), як величину зменшення часових орієнтирів в умовах прийняття купівельного рішення покупцем (кінцевим користувачем) товарів чи послуг. Поясненням такого ефекту виступає та причина, що згідно версії "А" (виконання обмінної процедури із запровадженням прийомів і практик технології інсайту), за реалізації маркетингових підказок і мотиваційних установок, купівельна поведінка споживача здобуває націленості на результат, що за версією Сьюзен Фовлер є найсуттєвішою мотивацією будь-якої поведінки [13, с. 12]. У такий спосіб ефектні мотиви, поштовхи або стимули є тими суб'єктними мотиваціями, що мають зараджувати підвищенню ефективності певної галузі суспільної діяльності, в тому числі і сфери торгівлі. 


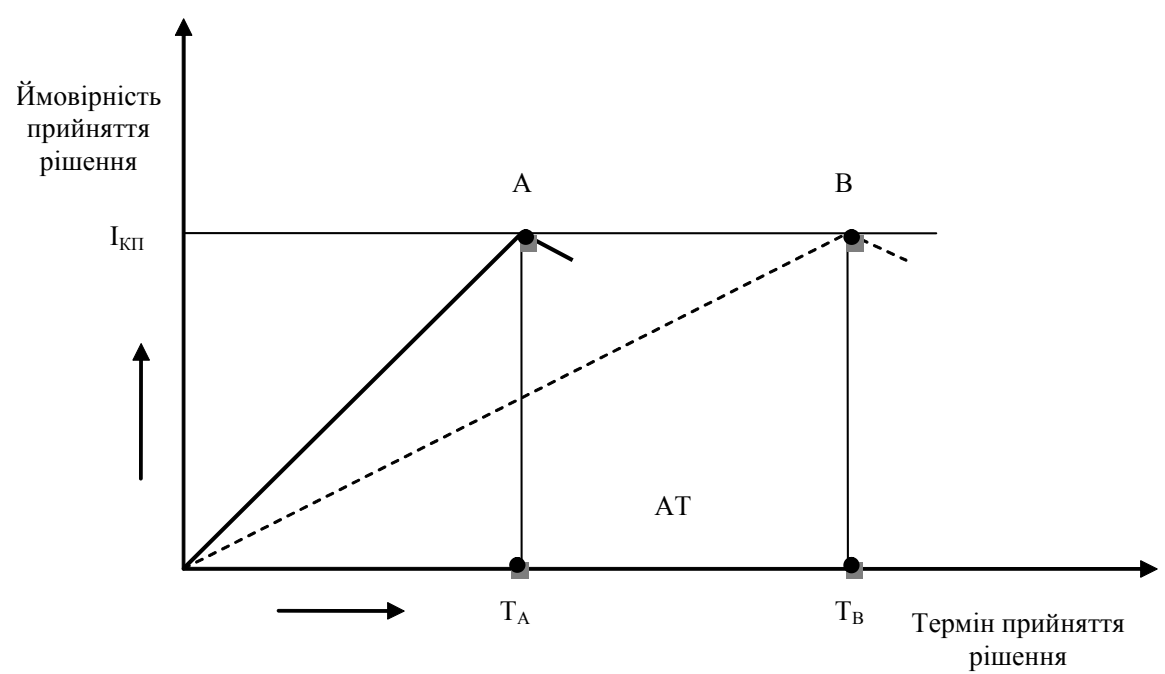

Рис. 2. Порівняльна модель тривалості прийняття рішення споживачем

Ажерело: власна розробка авторів.

Безпосередньо коефіцієнт ефективності провадження технології споживчого інсайту може бути вирахуваний за формулою:

$$
K_{E T}=\frac{\Delta T}{T_{B}}=\frac{T_{B}-T_{A}}{T_{B}}
$$

умови $\Longrightarrow T_{A}>0 ; T_{B}>0 ; 0<K E T<1 ; I_{K \Pi}=$ constant.

де: $K_{E T}-$ коефіцієнт ефективності технології інсайту;

$\Delta T$ - дельта-період часових орієнтирів;

$T_{A}$ - часовий орієнтир здійснення обмінної процедури із запровадженням технології інсайту, од. часового виміру;

$T_{B}$ - часовий орієнтир здійснення обмінної процедури за традиційним форматом, од. часового виміру;

$I_{K \Pi}$ - імовірність настання купівельної події, умовні од.

Надаючи деякі роз'яснення щодо окремих складників формули (1), доцільно визначити те положення, що дельта-період часових орієнтирів $\left(\Delta T=T_{B}-T_{A}\right)$ буде набувати тенденцію до збільшення при зменшенні числового значення показника часового орієнтира $T_{A}$, тобто за умови більш раннього спрацьовування механізмів технології інсайту. У такий спосіб при $T_{A} \rightarrow \min$ станемо мати $\Delta T \rightarrow \max$ та згідно із цим $K_{E T}^{A} \rightarrow$ від 0 до 1 . Мінімальне значення $K_{E T}$ може бути зафіксоване за умови, коли $T_{A}=T_{B}, \Delta T=$ 0 й $K_{E T}=0$, тобто у тім випадку, якщо обидва часові орієнтири $\left(T_{A}\right.$ і $\left.T_{B}\right)$ співпадають у часі. Натомість максимальне значення $K_{E T}$ матиме місце за тієї ситуації, коли $T_{A}=0, \Delta T=K_{B}$ та $K_{E T}=1$, тобто за тих умов, відколи споживач приймає остаточне купівельне рішення на початку часового відліку.
Схвалення кінцевим споживачем власного рішення щодо здійснюваної ним купівельної дії у випадку запровадження технології споживчого інсайту не є ані імпульсивною, ані спонтанною, ані провокаційною подією, оскільки в довідниках імпульсивність тлумачиться як схильність людини діяти під впливом раптового та короткочасного збудження в нервових клітинах [14, с. 22], спонтанність має прояв в ситуаціях, які виникають за дії виключно внутрішніх, а не зовнішніх причинних подразників [2, с. 571], провокаційний хід подій реалізується за фактом штучного утворення складних обставин чи негативних результатів для тих, кого провокують до виконання шкідливих Аля них вчинків [15, с. 144]. Враховуючи те, що інсайт, як психологічне явище, виступає у статусі радісно-емоційного осяяння: здогадки під час вирішення назрілого завдання або проблеми [1, с. 306], технологія споживчого інсайту відіграє роль підказки, пропозиції чи поради.

На закінчення є логічним визнати, що дослідження поведінки споживача під час прийняття рішення про купівельну подію та фактичного здійснення цієї дії, сприяє збагаченню положень маркетингу і визначає принципово нові можливості для маркетологів. У свою чергу фахові дії цих спеціалістів допомагають покупцям орієнтуватися на ринку товарів і послуг та вдосконалювати особистісні навички й уміння в області суб'єктного маркетингу.

\section{ВИСНОВКИ З ПРОВЕДЕНОГО ДОСЛІДЖЕННЯ І ПЕРСПЕКТИВИ ПОДАЛЬШИХ РОЗВІДОК У ДАНОМУ НАПРЯМІ}

Одним із завдань маркетингу є утворення споживчого інсайту на основинах мотивацій- 
ної установки чи маркетингової підказки кінцевому покупцю стосовно траєкторії купівельної поведінки у відношенні до певного товару чи послуги. Знання маркетологом інсайтної психології кінцевого споживача має продуктивно впливати на манери його купівельної поведінки в частині прийняття підсвідомого рішення щодо придбання товару або отримання послуги. Такий сценарій $€$ вельми актуальним в ситуації, коли товарно-інформаційний ринок є вкрай перенасиченим і ефективність маркетингових заходів помітно зменшується.

Окрім мотиваційного заохочення, технологія споживчого інсайту припускає зменшення терміну утвердження споживачем рішення щодо запроваджуваної ним купівельної дії. Суб'єктна націленість на результат є за означеною технологією найсуттєвішою мотивацією (поштовхом, стимулом чи мотивом) для споживача на багатоцільовому ринку товарів та послуг. I тільки такі організації, які зможуть масштабно дослідити й вивчити механізми заохочення (мотивування) споживачів, матимуть надію на розширення збуту продукції і отримання прибутків.

\section{$\Lambda$ ітература:}

1. Скопненко O.І., Цимбалюк Т.В. Сучасний словник іншомовних слів. К.: Аовіра, 2006. $789 \mathrm{c}$.

2. Білодід І.К. Словник української мови: в 11 т. К.: Наукова думка, 1978. Т. 9.917 с.

3. Котлер Ф. Основы маркетинга. Краткий курс. Пер. с англ. М.: "Вильямс", 2007. 656 с.

4. Drucker P. Management, Task, Responsibilities and Practices. New York, 1973. 553 p.

5. Drucker Peter. The Practice of Management. New York: Harper \& Row, 1954. 603 c.

6. Білодід І.К. Словник української мови: в 11 т. К.: Наукова думка, 1979. Т. 10.658 с.

7. Клаус Мозер. Психология маркетинга и рекламы / Пер. с неа. Х.: Изд-во Гуманитарный Центр, 2004. 380 с.

8. Мельничук О.С. Словник іншомовних слів. Київ: Головна редакція УРЕ, 1985.968 с.

9. Liberman M.D. Intuition: A social cognitive neuroscience approach. Psychological Bulletin. 2000. V. 126. № 1. Pp. 109-137.

10. Ильин Е.П. Психология творчества, креативности, одаренности. СПб: Питер, 2009. 448 с.

11. De Fleur M. Theories of mass communication. New York: McKay, 1970. 128 p.

12. Житарюк М.Г. Теорії та моделі масової інформації. Аьвів, 2015. 220 с.
13. Сьюзен Фовлер. Націлені на результат. Що насправді мотивує людей/ пер. $з$ англ. Юлії Кузьменко. К.: Наш формат, 2018. 168 с.

14. Білодід I.К. Словник української мови: в 11 т. К.: Наукова думка, 1973. Т. 4.840 с.

15. Білодід I.К.Словник української мови: в 11 т. К.: Наукова думка, 1977. Т. 8. 927 с.

\section{References:}

1. Skopnenko, O.I. and Tsymbalyuk, T.V. (2006), Suchasnyy slovnyk inshomovnykh sliv [Modern dictionary of foreign words], Dovira, Kyiv, Ukraine.

2. Bilodid, I.K. (1978), Slovnyk ukrayins'koyi movy [Dictionary of the Ukrainian language], vol. 9, Naukova dumka, Kyiv, Ukraine.

3. Kotler, F. (2007), Osnovy marketinga. Kratkiy kurs [Fundamentals of Marketing. Short course], Vil'yams, Moscow, Russia.

4. Drucker, P. (1973), Management, Task, Responsibilities and Practices, New York, USA.

5. Drucker, P. (1954), The Practice of Management, Harper \& Row, New York, USA.

6. Bilodid, I.K. (1979), Slovnyk ukrayins'koyi movy [Dictionary of the Ukrainian language], vol. 10, Naukova dumka, Kyiv, Ukraine

7. Mozer, K. (2004), Psikhologiya marketinga i reklamy [Psychology of Marketing and Advertising], Izd-vo Gumanitarnyy Tsentr, Kharkiv, Ukraine.

8. Mel'nychuk, O.S. (1985), Slovnyk inshomovnykh sliv [Dictionary of foreign words], Holovna redaktsiya URE, Kyiv, Ukraine.

9. Liberman, M.D. (2000), "Intuition: A social cognitive neuroscience approach", Psychological Bulletin, vol. 126, no. 1, pp. 109-137.

10. Il'in, E.P. (2009), Psikhologiya tvorchestva, kreativnosti, odarennosti [Psychology of creativity, creativity, giftedness], Piter, St.Petersburg, Russia.

11. De Fleur, M. (1970), Theories of mass communication, McKay, New York, USA.

12. Zhytaryuk, M.H. (2015), Teoriyi ta modeli masovoyi informatsiyi [Theories and models of mass information], L'viv, Ukraine.

13. Fovler, S. (2018), Natsileni na rezul'tat. Shcho naspravdi motyvuye lyudey [Aimed at the result. What really motivates people], Nash format, Kyiv, Ukraine.

14. Bilodid, I.K. (1973), Slovnyk ukrayins'koyi movy [Dictionary of the Ukrainian language], vol. 4, Naukova dumka, Kyiv, Ukraine.

15. Bilodid, I.K. (1977), Slovnyk ukrayins'koyi movy [Dictionary of the Ukrainian language], vol. 8, Naukova dumka, Kyiv, Ukraine.

Стаття надійшла до редакиї̈ 04.01.2022 p. 
С. М. Аанькевич, к. с.-Г. Н., Аокторант, Інститут агроекології і природокористування НААН

ORCID ID: 0000-0003-2597-4461

\title{
ПОТЕНЦІАА ФІНАНСОВО-ЕКОНОМІЧНОГО МЕХАНІЗМУ В УСУНЕННI АИСБАЛАНСІВ АІСОГОСПОААРСЬКОГО ЗЕМЛЕКОРИСТУВАННЯ
}

\author{
S. Dankevych, \\ $\mathrm{PhD}$ in Agricultural Sciences, Institute of Agroecology and Nature Management of NAAS
}

\author{
THE POTENTIAL OF THE FINANCIAL AND ECONOMIC MECHANISM IN ELIMINATING \\ IMBALANCES IN FORESTRY LAND USE
}

\begin{abstract}
Регіональні відмінності екологічної та соціально-економічної збалансованості використання земель лісогоспоАарського призначення зумовлюють необхідність функціонування фінансово-економічного механізму лісогоспоАарського землекористування. Уточнено та узагальнено сутність і роль фінансово-економічного механізму забезпечення збалансованого використання земель лісогосподарського призначення як наукової основи подальшого економічного зростання України. ІАентифіковано чинники, сприятливі для забезпечення збалансованого використання земель лісогосподарського призначення. Запропоновано оцінку рівня збалансованості використання земель лісогосподарського призначення кожного регіону проводити з урахуванням таких значимих індикаторів, як екологічна збалансованість та соціально-економічна збалансованість. Запропоновано запровадити нові показники звітності лісогосподарських підприємств, які можуть бути використані як індикатори збалансованості дісогосподарського землекористування в кожного регіону. Запропоновано методичні підходи до оцінки управлінських заходів щодо екологічної та соціально-економічної збалансованості лісогосподарського землекористування, яка може бути використання задля удосконалення нормативної грошової оцінки земель лісогосподарського призначення, а відтак і податкового стимулювання забезпечення збалансованого використання лісових земель. Розроблено інституціональне підгрунтя забезпечення збалансованого використання земель лісогосподарського призначення, розроблено конкретні пропозиції внесення змін до законодавчих та інших нормативно-правових актів України.
\end{abstract}

Regional differences in the ecological and socio-economic balance of forest land use necessitate the functioning of the financial and economic mechanism of forest land use. The essence and role of the financial and economic mechanism of ensuring the balanced use of forest lands as a scientific basis for further economic growth of Ukraine are specified and generalized. The information base of the study is the data of the Global Assessment of Forest Resources of FAO 2020, the data of the Monitoring of Land Relations in Ukraine, the reporting of the State Forest Agency of Ukraine. The study found both negative and positive correlations between different strengths and degrees of influence between factors and performance indicators. Factors favorable for ensuring balanced use of forest lands have been identified. Favorable factors for ensuring the balanced use of forest lands in the national economy are reforestation, forest certification, renewal of fixed assets of forest enterprises through the improvement of investment instruments, reducing the tax burden on forestry activities. It is proposed to assess the level of balance of forest land use in each region, taking into account such important indicators as environmental balance and socio-economic balance. It is proposed to introduce new indicators of reporting of forestry enterprises, which can be used as indicators of the balance of forestry land use in each region. Methodological approaches to the assessment of management measures for environmental and socio-economic balance of forest land use, which can be used to improve the regulatory monetary valuation of forest lands, and thus tax incentives to ensure balanced use of forest lands. The institutional basis for ensuring the balanced use of forest lands has been 
developed, specific proposals for amendments to legislative and other normative legal acts of Ukraine have been developed. Ensuring the balanced use of forest lands can ensure further economic growth of Ukraine and the achievement of sustainable development goals set by the Basic Principles (Strategy) of the State Environmental Policy of Ukraine for the period up to 2030 .

Ключові слова: землі лісогосподарського призначення, збалансоване землекористування, екологічна збалансованість, сочіально-економінна збалансованість, інструментарій.

Key words: land for forestry, balanced land use, ecological balance, socio-economic balance, tools.

\section{ПОСТАНОВКА ПРОБЛЕМИ}

"Ведення державної політики в сфері земельних відносин із метою одержання економічної вигоди без урахування екологічних інтересів спричинила екологічну кризу в землекористуванні" [1]. Основними засадами (стратегією) державної екологічної політики України на період до 2030 року [2] до головних причин виникнення проблем у лісовій сфері України віднесено недосконалість системи управління лісовим господарством, яка посилюється відмінностями соціально-економічного розвитку регіонів. У лісовій галузі необхідність усунення регіональних диспропорцій лісогосподарського землекористування викликана "недосконалістю фінансового та економічного механізму" [3]. Втім, наявні диспропорції можна врегулювати завдяки застосуванню універсального інструментарію фінансово-економічного механізму впливу на господарюючі суб'єкти з метою досягнення екологічно безпечного землекористування [1]. За дослідженнями [4; 5] інструментом уникнення існуючих дисбалансів у рівнях соціально-економічного розвитку регіонів $\epsilon$ підхід 3 точки зору концепції збалансованого розвитку.

\section{АНАЛІЗ ОСТАННІХ ДОСЛІДЖЕНЬ І ПУБЛІКАЦІЙ}

Проблематика досягнення збалансованого лісокористування $є$ предметом досліджень широкого кола вчених. Інституціоналізацію лісового сектора економіки в контексті сталого розвитку України досліджено Аребот О. [68]. Пріоритети національної стратегії збалансованого розвитку землекористування України досліджено вченими Фурдичко О. [7; 8], Паляничко Н. [7; 8], Подлевська О. [4]. Економічне стимулювання застосування природоохоронних заходів землекористування досліджено вченими Аорош О. та Фоменко В. [1]. Теоретико-методологічні підходи до функціонування економічних інструментів у сфері управління земельними ресурсами досліджено в працях Третяка А. [9], Johansson J. [10]. Показники, які характеризують стан збалансованості використання земель лісогосподарського призначення та їх взаємовпливи, досліджено вченими Karenlampi P. [11], Сокіл O. [12], Liubachyna A. [13], Bukvareva E. [14], Zamula I. [15], PiwowarSulej K. [5]. Проблемам впровадження науково обгрунтованих управлінських рішень щодо використання природно-ресурсного потенціалу лісогосподарських земель в діяльності суб'єктів господарювання, функціонування систем економічного стимулювання раціонального використання лісових ресурсів та лісових територій для досягнення збалансованості екологічного, економічного та соціального розвитку територій присвячено праці В. Касюхнича [3]. Однак, незважаючи на значний обсяг теоретичних і методологічних досліджень, низка питань щодо забезпечення ефективного функціонування фінансово-економічного механізму збалансованого використання земель лісогосподарського призначення за регіонами України досі залишаються малоопрацьованими.

\section{META CTATTI}

Мета статті здійснити теоретико-методичне обгрунтування організаційно-економічних чинників удосконалення інструментів фінансово-економічного механізму забезпечення збалансованого використання земель лісогосподарського призначення в регіональному аспекTi.

\section{МЕТОДИКА ДОСЛІДЖЕННЯ}

Аля досягнення поставленої мети авторами використано такі методи: діалектичний метод пізнання для аналізу законодавчих та нормативних актів і наукових праць вчених відносно проблематики збалансованого використання земель лісогосподарського призначення; аналіз найбільш актуальних проблем функціонування економічних та фінансових інструментів фінансово-економічного механізму збалансованого лісогосподарського землекористування; синтез і логічне узагальнення концептуальних основ необхідності і передумов удос- 
коналення інструментів; монографічний для виявлення чинників удосконалення інструментів; абстрактно-логічний теоретичні узагальнення та формулювання висновків; метод аналогій. Інформаційною базою дослідження $€$ дані звітності Аержлісагенства України, Глобальної оцінки лісових ресурсів ФАО 2020, Моніторингу земельних відносин в Україні.

\section{ВИКЛАДЕННЯ ОСНОВНОГО МАТЕРІАЛУ}

Вчені [9] акцентують увагу на необхідності збалансування цілей збереження лісів з економічною потребою в вирубці лісів та правом громад отримувати прибуток від експлуатації лісів. Зазначене підкреслює єдність економічних, соціальних та екологічних цілей України, що зумовлює необхідність забезпечення збалансованого використання земель лісогоспоАарського призначення [5]. Термін збалансоване використання земель лісогосподарського призначення пропонуємо визначати як систему заходів, при якій досягається динамічна рівновага лісокористування 3 екологічною системою на основі врахування природних якостей лісових екоситем, властивостей земель лісогосподарського призначення, їх цінності та особливостей природнопросторового розташування, що забезпечить отримання широкого спектру соціальних, економічних, екологічних та культурних вигод для нинішнього і майбутніх поколінь. На підставі проведених нами розрахунків отримано різний характер кореляційних зв'язків між показниками, що дозволило зробити припущення про найважливіші чинники, які мають вплив на забезпечення збалансованого використання земель лісогосподарського призначення (табл. 1).

Отже, оцінювання міри впливу окремих чинників на рівень певних результативних показників допоможе розрахувати екологічну та соціально-економічну збалансованість лісогосподарського землекористування кожного регіону. Фінансово-економічний механізм збалансованого використання земель лісогосподарського призначення включає широку специфікацію інструментів і прямо та опосередковано закладає екологічну домінанту в діяльність на землях лісогосподарського призначення [7]. Нами запропоновано підхід до формування структури фінансово-економічного механізму збалансованого використання земель лісогосподарського призначення, який систематизовано за чотирма взаємопов'язаними інструментальними блоками: екологічним, економічним, організаційним та фінансовим (рис. 1).

Ао екологічних інструментів віднесено такі інструменти, як сертифікація [6, с. 121] та стандартизація; до економічних: податкові пільги, вуглецеві ринки, стабільне інвестиційне середовище, біоенергетика, біоекономіка, формування ринку екосистемних послуг, субсидії, страхування ризиків, компенсація збитків, аналіз показників; до організаційних: удосконалення інституціонального поля, система управління, аудит, аналіз політики, комплексний моніторинг, приватно-державне партнерство, інвентаризація, добровільний кодекс поведінки, освіта, доступ до інформації; до фінансових: 
програми платежів за екосистемні послуги, екологічні податки, фіскальна політика, дотації, компенсаційні виплати, відшкодування втрат, кредитна політика, пені, штрафи.

Вчені [14] зазначають, що інструмент управління вимагає врахування причинно-наслідкових зв'язків між показниками, які виникають внаслідок впливу певних чинників. Отже, досліджені нами диспропорції використання лісових земель зумовлюють необхідність оцінки управлінських заходів з метою досягнення збалансованого використання земель лісогосподарського призначення на регіональному рівні. Вчені [15] наголошують про важливість порівняння показників, що характеризують певні результати в умовах економічного дисбалансу на регіональному рівні. Оцінку управлінських заходів щодо забезпечення

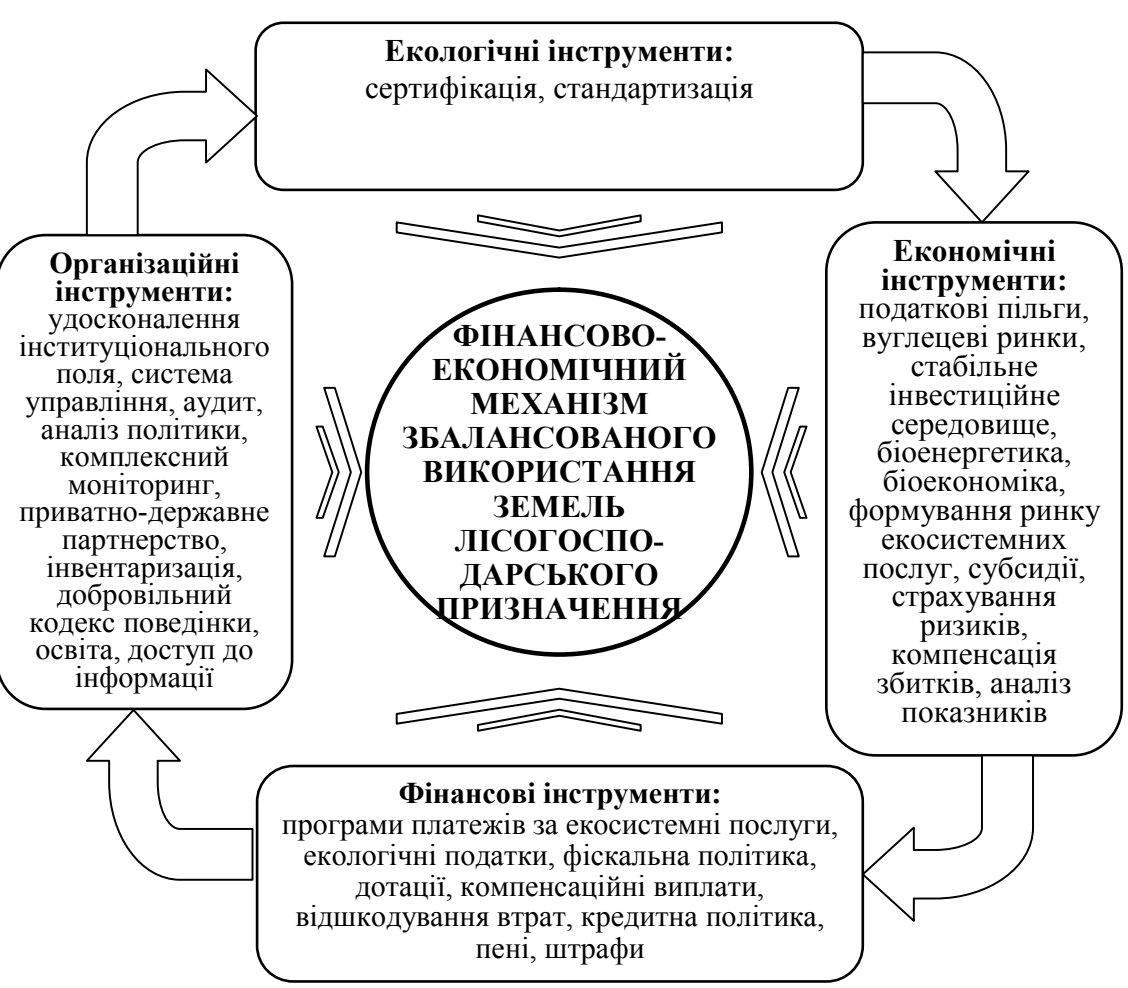

Рис. 1. Схематичне зображення інструментів фінансовоекономічного механізму збалансованого використання земель лісогосподарського призначення

Ажерело: розроблено автором. екологічної збалансованості використання земель лісогосподарського призначення на місцевому та регіональному рівнях пропонуємо здійснити за формулою 1:

$$
B_{t}^{e}=\sum_{j=1}^{n} E_{j t}
$$

де $B_{t}^{e}$ - оцінка управлінських заходів щодо екологічної збалансованості лісогосподарського землекористування конкретного регіону у $t$-му періоді;

$E_{j t}$ - збалансованість екологічної складової використання земель лісогосподарського призначення в $t$-му періоді, бал (наприклад, співвідношення фактичної лісистості та оптимальної; співвідношення лісів за першочерговими цілями управління; стан лісової сертифікації; стан накопичення вуглецю в наземній біомасі лісів, у біомасі грунту лісів; стан еродованості грунтів; оцінка щільності пожеж; тощо);

$n$ - кількість екологічних та соціально-економічних показників, які враховуються при оцінці стану збалансованості використання земель лісогосподарського призначення кожного регіону.

Оцінку управлінських заходів щодо забезпечення соціально-економічної збалансованості використання земель лісогосподарського призначення на місцевому та регіональному рівнях пропонуємо здійснити за формулою 2:

$$
B_{t}^{c e}=\sum_{j=1}^{n} C E_{j t}
$$

де $B_{t}^{c e}$ - оцінка управлінських заходів щодо соціально-економічної збалансованості лісогосподарського землекористування конкретного регіону у $t$-му періоді;

$\mathrm{CE}_{\mathrm{jt}}$ - показник збалансованості соціально-економічного результату в $t$-му періоді, бал (наприклад, оцінка капітальних інвестицій на 1 га земель лісогосподарського призначення; співвідношення обсягів фінансування лісових земель та податкового навантаження; оцінка фінансової стійкості, ліквідності, ділової активності; забезпеченість кадрами відповідної кваліфікації; співвідношення продуктивності праці та доходів працівників тощо);

n - кількість екологічних та соціально-економічних показників, які враховуються при оцінці стану збалансованості використання земель лісогосподарського призначення кожного регіону.

Враховуючи ризик тривалості у лісовому господарстві [11], часовий період $t$ пропонуємо визначати не меншим, ніж 3-5 років. За результатами такої оцінки регіональні поліпшення будуть демонструвати вирішення існуючих проблем та стан досягнення цілей державної 


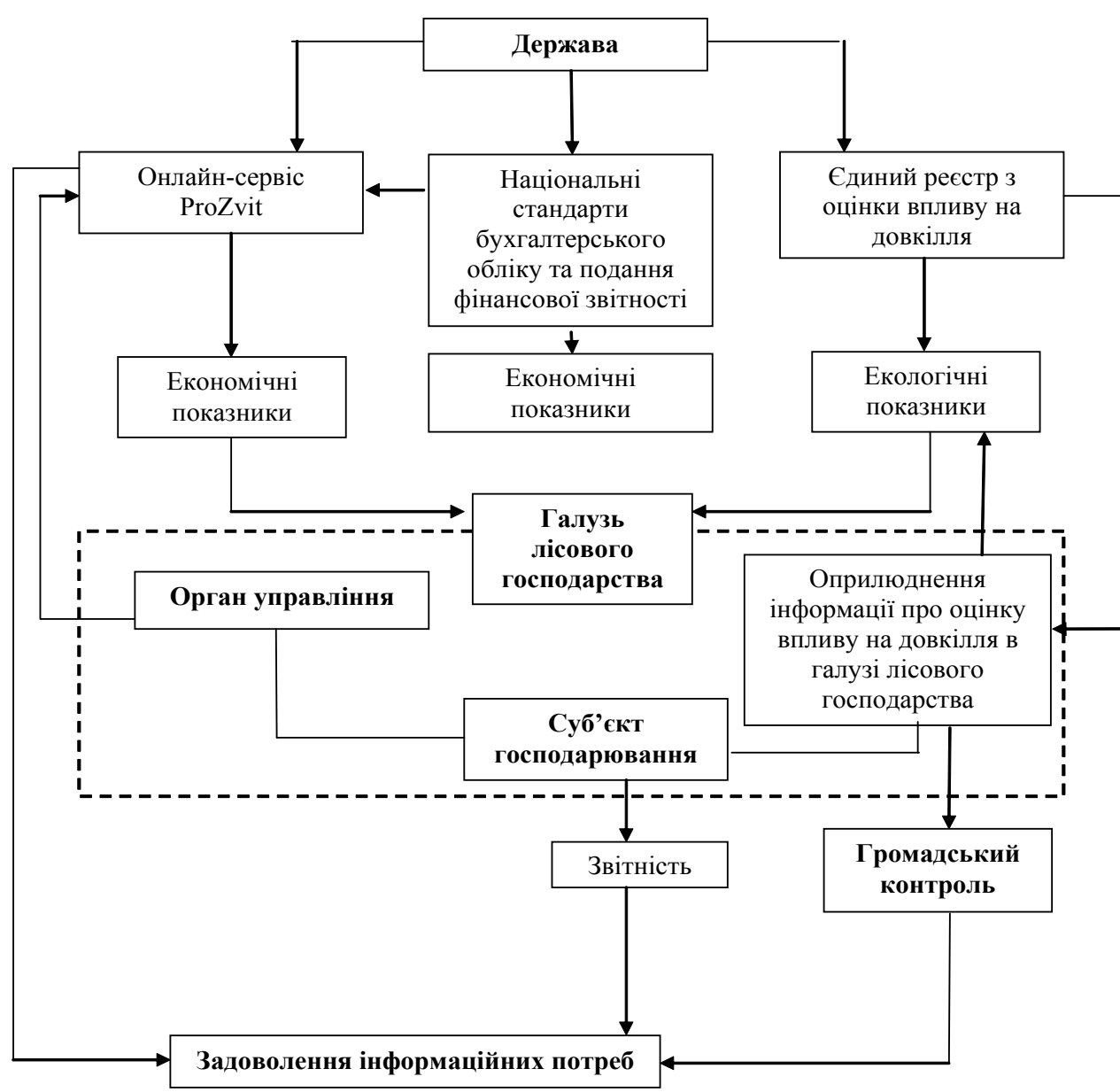

Рис. 2. Структурна схема інформаційного доступу до показників використання земель лісогосподарського призначення

Ажерело: розроблено автором.

екологічної політики, які визначені Основними засадами (стратегією) державної екологічної політики України на періоддо 2030 року [2].

На нашу думку, необхідним є удосконалення чинної методики нормативного оцінювання земель саме лісогосподарського призначення [16] шляхом урахування залежності від запропонованих показників оцінки управлінських заходів щодо стану екологічної та соціальноекономічної збалансованості використання земель лісогосподарського призначення. Таким чином нормативна грошова оцінка (НГО) земель лісогосподарського призначення впливатиме на прийняття управлінських рішень щодо збалансованості лісогосподарського землекористування. Оскільки НГО земель є базою для оподаткування, логічно, що лісогосподарські підприємства, які забезпечуватимуть збалансоване використання земель лісогосподарського призначення, повинні мати менше податкове навантаження. Тобто база оподаткування виступатиме економічним інструментом і виконуватиме стимулюючу функцію щодо забезпечення екологічної та соціально-економічної зба- лансованості використання земель лісогосподарського призначення. Отже, удосконалення методологічних основ функціонування фінансово-економічного механізму сприятиме забезпеченню збалансованого рівня використання лісових земель на місцевому рівні.

Зазначене в свою чергу вимагає розширення показників моніторингу на місцевому та національному рівнях. FAO 2020 [17] наводить дані різних країн про стан і тенденції понад 60-ти пов'язаних 3 лісами показників. Моніторинг земельних відносин в Україні [18] охоплює 65 показників стосовно стану управління земельними ресурсами. Ми пропонуємо запозичити досвід FAO та запровадити в Україні оприлюднення суб'єктами господарювання системи екологічних показників, наприклад, накопичення вуглецю в лісових насадженнях та зміни такого накопичення, доповнивши ними інформаційну базу моніторингу. Перевагами запровадження екологічних показників є пом'якшення або запобігання негативним екологічним, соціальним та економічним впливам [12] землекористування, що буде потужним стимулом формування внутрішньої політики збалансованого використання земель лісогосподарського призначення в Україні.

Інформаційний доступ є компонентом інструменту управління лісогосподарського землекористування [10]. Необхідно зазначити, що збалансоване землекористування можливе за умов поєднання фінансово-економічних інструментів та їх цілеспрямованого впливу на суб'єктів господарювання з урахуванням якості комунікації між представниками органів державної влади, місцевого самоврядування, громади і бізнесу. Вчені [9] до сильних сторін використання земель лісогосподарського призначення відносять значний вплив громадськості 
Таблиця 2. Пропозиції внесення змін до законодавчих та інших нормативно-правових актів

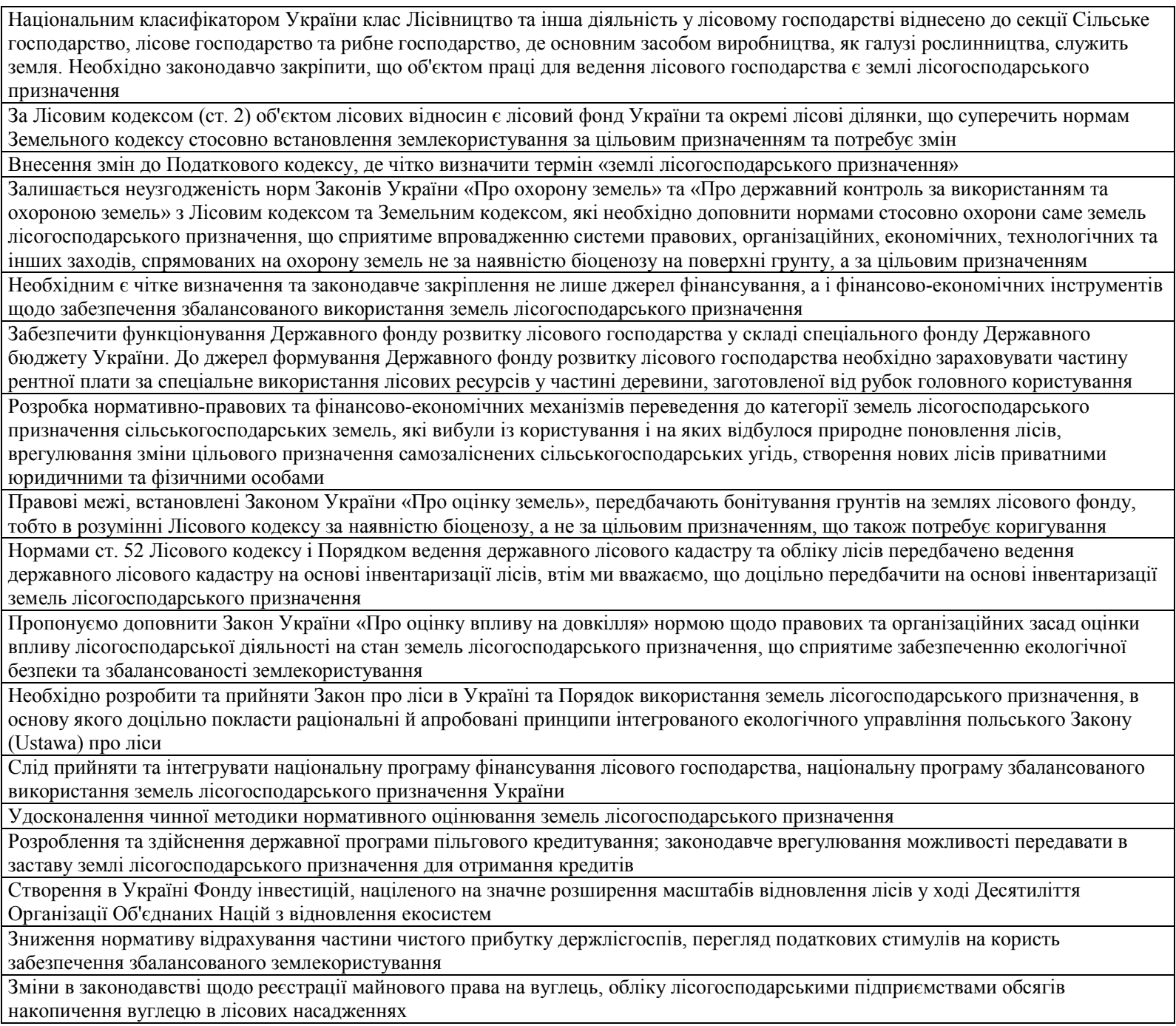

Ажерело: розроблено автором.

на процеси лісокористування на місцевому рівні. Хоча на сьогодні лісогосподарські підприємства і переглянути свої стратегії розкриття інформації для громадськості [13], втім, необхідно, щоб звітність лісогосподарських підприємств відображала результати діяльності в контексті екологічної та соціально-економічної збалансованості використання лісових земель, для чого необхідні стандартизовані рамки відображення показників для можливості проведення порівняльного аналізу. Структурна схема доступу зацікавлених сторін до показників звітності про стан лісогосподарського землекористування (рис. 2) наочно демонструє можливості громадського контролю за веденням господарської діяльності на екологічній основі [8].

Методичні рекомендації з розробки звіту з оцінки впливу на довкілля в галузі лісового господарства [19] надають можливості громадсь- кого контролю таких видів планової діяльності: усі суцільні та поступові рубки головного користування і суцільні санітарні рубки на площі понад 1 гектар; лісогосподарське освоєння на територіях площею 20 га і більше; насадження лісу (крім лісовідновлювальних робіт) на площах понад 20 га.

Вчені [1] наголошують, що наявність інституційної бази відноситься до числа факторів які формують можливості використання інструментів фінансово-економічного механізму. Ідентифікація чинників, сприятливих для екологічної та соціально-економічної збалансованості лісогосподарського землекористування, $€$ основою змін інституціонального підгрунтя забезпечення збалансованого використання земель лісогосподарського призначення. Наведені в таблиці 2 пропозиції щодо розробки та внесення змін до законодавчих та інших нормативно-правових актів сприятимуть форму- 
ванню в суспільстві усвідомлення самої парадигми збалансованого використання земель лісогосподарського призначення.

Запропоновані інституціональні зміни гармонізації екологічних і соціально-економічних інтересів лісогосподарського землекористування дадуть можливість підвищити ефективність управління процесом забезпечення збалансованого використання лісових земель кожного регіону.

\section{ВИСНОВКИ}

Обгрунтовано залежність досягнення збалансованого використання земель лісогосподарського призначення від фінансово-економічного забезпечення екологічної безпеки. За результатами дослідження було виявлено як негативну, так і позитивну кореляцію різної сили зв'язку та ступеня впливу між чинниками та результативними показниками. Сприятливими чинниками для забезпечення збалансованого використання земель лісогосподарського призначення в національній економіці є відтворення лісів, сертифікація лісів, оновлення основних засобів лісогосподарських підприємств через удосконалення інструменту інвестицій, зменшення податкового навантаження лісогосподарської діяльності. Забезпечення збалансованого використання земель лісогосподарського призначення може забезпечити подальше економічне зростання України та досягнення цілей сталого розвитку, визначених Основними засадами (стратегією) державної екологічної політики України на період до 2030 року.

Запропоновано та науково обгрунтовано теоретичні підходи функціонування фінансово-економічного механізму забезпечення збалансованого використання земель лісогосподарського призначення, який доводить необхідність розвитку інституцій управління лісогосподарським землекористуванням на засадах удосконалення нормативно-законодавчого поля із залученням різноманітних форм і методів управління, що засновується на науково обгрунтованих підходах. Систематизовано інструментарій фінансово-економічного механізму, який диференційовано відповідно до рівня збалансованості лісогосподарського землекористування кожного регіону, що дає змогу обрати оптимальні інструменти, а також методи їх застосування з метою досягнення екологічної та соціально-економічної збалансованості. Обгрунтовано, що удосконалення показників звітності $є$ інструментом контролю та моніторингу забезпечення збалансованого використання земель лісогосподарського призначення.
Запропоновано шляхи удосконалення функціонування інституціонального регулятора задля фінансово-економічного забезпечення збалансованого використання земель лісогосподарського призначення: розроблення та здійснення національної стратегії фінансування збалансованого лісогосподарського землекористування; розроблення та здійснення державної програми пільгового кредитування; законодавче врегулювання можливості передавати в заставу землі лісогосподарського призначення для отримання кредитів; створення в Україні Фонду інвестицій, націленого на значне розширення масштабів відновлення лісів у ході Аесятиліття Організації Об'єднаних Націй 3 відновлення екосистем; зниження нормативу відрахування частини чистого прибутку держлісгоспів до рівня 2018 р.; перегляд податкових стимулів на користь забезпечення збалансованого землекористування; прийняття Закону України "Про екологічне страхування"; зміни у законодавстві щодо реєстрації майнового права на вуглець, обліку лісогосподарськими підприємствами обсягів накопичення вуглецю в лісових насадженнях, розвитку внутрішнього вуглецевого ринку, що дасть можливість додаткових фінансових надходжень. Подальші дослідження будуть спрямовані на удосконалення інструментарію забезпечення збалансованості використання земель лісогосподарського призначення

\section{$\Lambda$ ітература:}

1. Dorosh O., Fomenko V., Kupriyanchik I., \& Svyrydova L. Фінансово-економічний механізм як універсальний інструментарій переведення землекористування на модель сталого розвитку. Землеустрій, кадастр і моніторинг земель. 2019. № 2. C. 13-22. URL: doi:http://dx.doi.org/ 10.31548/zemleustriy2019.02.02

2. Про Основні засади (стратегію) державної екологічної політики України на період до 2030 року: Закон України від 28.02.2019 р. № 2697-VIII. URL: https://zakon.rada.gov.ua/ laws/show/2697-19/

3. Касюхнич В.Ю. Ефективність використання природно-ресурсного потенціалу земель лісогосподарського призначення. Збалансоване природокористування. 2017. № 2. С. 134-139.

4. Подлевська О.М., Красовська Ю.В. Пріоритети національної стратегії збалансованого розвитку України. Економіка і суспільство. 2017. № 8. C. 477-481. URL: https://economyandsociety.in.ua/journals/8_ukr/82.pdf

5. Piwowar-Sulej K. Core functions of Sustainable Human Resource Management. A hybrid 
literature review with the use of $\mathrm{H}$-Classics methodology. Sustainable Development. 2021. № 29. C. 671-693. URL: https://doi.org/10.1002/sd.2166

6. Аребот O.I. Інституціоналізація лісового сектора економіки в контексті сталого розвитку України: монографія. К.: АIA, 2012. - 336 с.

7. Фурдичко O.I., Аребот O.I., Паляничко H.I., Аанькевич C.M., Інструменти фінансовоекономічного механізму збалансованого використання земель лісогосподарського призначення України. Облік і фінанси. 2020. № 4 (90). C. 144-157. URL: https://doi.org/10.33146/23079878-2020-4(90)-144-157

8. Фурдичко O.I., Аребот О.І., Паляничко Н.I., Аанькевич С.М., Окабе Й. Еколого-економічна звітність як індикатор стану лісогосподарського землекористування. Agricultural and Resource Economics E-Journal. 2021. Vol. 7. № 2. C. 219-250. URL: https://doi.org/10.51599/ are.2021.07.02.12

9. Tretiak A., Tretiak V., Sakal O., Kovalenko A., Tretiak N., Shtogryn H. The value added chain in the mechanism of public-private partnership for the development of the land use economy of rural territories. Agricultural and Resource Economics. 2020. Vol. 6. № 3. Pp. 112-134. URL: https://doi.org/10.51599/are.2020.06.03.07

10. Johansson J., Ranius Th. Biomass outtake and bioenergy development in Sweden: the role of policy and economic presumptions. Scandinavian Journal of Forest Research. 2019. Vol. 34 (8). P. 771778. URL: https://doi.org/10.1080/02827581.2019.1691645

11. Karenlampi P.P. Capital Return Rate and Carbon Storage on Forest Estates of Three Boreal Tree Species. Sustainability. 2021. Vol. 13. № 12. 6675. URL: https://doi.org/10.3390/su13126675

12. Сокіл О.Г. Теоретико-методологічні засади бухгалтерського обліку сталого розвитку сільськогосподарських підприємств: монографія. Мелітополь: ТОВ "Колор Принт", 2018. 454 c. URL: http://elar.tsatu.edu.ua/bitstream/ $123456789 / 8045 / 1 / \%$ D 0\% 9C \% D 0\%BE\% D 0 \% B D \% D 0 \% B 3\% D $1 \% 80 \%$ D $0 \%$ B 0\% $\mathrm{D} 1 \% 84 \% \mathrm{D} 0 \% \mathrm{~B} 8 \% \mathrm{D} 1 \% 8 \mathrm{~F}+\% \mathrm{D0} \% \mathrm{~A} 1 \% \mathrm{D0} \% \mathrm{BE} \% \mathrm{D} 0 \%{ }^{-}$ BA $\%$ D $1 \% 96 \%$ D0 $\%$ BB_ 2018 \% $\% 0 \% 905 \% 20 \%$ D1 $\% 80 \% \mathrm{D} 0 \% \mathrm{~B} 5 \% \mathrm{D} 0 \% \mathrm{~B} 4 \% \mathrm{D0} \% \mathrm{~B} 0 \% \mathrm{D} 0 \% \mathrm{BA} \%-$ D1 $\% 86 \%$ D0 $\%$ B $8 \%$ D1 $\% 8$ F.pdf

13. Liubachyna A., Secco L., Pettenella D. Reporting practices of State Forest Enterprises in Europe. Forest Policy and Economics. 2017. Vol. 78. Pp. 162-172. URL: https://doi.org/10.1016/ j.forpol.2017.01.019

14. Bukvareva E., Grunewald K., Klimanova O., Kolbovsky E., Shcherbakov A., Sviridova T., Zamolodchikov D. TEEB-Russia: Towards Natio- nal Ecosystem Accounting. Sustainability. 2021. Vol. 13. № 12. 6678. URL: https://doi.org/10.$3390 /$ su 13126678

15. Zamula I., Tanasiieva M., Travin V., Nitsenko V., Balezentis T., Streimikiene D. Assessment of the Profitability of Environmental Activities in Forestry. Sustainability. 2020. № 12, 2998. URL: https://doi.org/10.3390/su12072998

16. Про затвердження Методики нормативної грошової оцінки земельних ділянок: Постанова Кабінету Міністрів України від 03.11.2021 р. № 1147. URL: https://www.kmu.gov.ua/npas/prozatverdzhennya-metodiki-normativnoyigroshovoyi-ocinki-zemelnih-dilyanok-1147-031121/

17. ФАО. 2021. Глобальная оценка лесных ресурсов 2020 года. Основной отчет. Рим. URL: https://doi.org/10.4060/ca9825ru

18. Моніторинг земельних відносин в Україні: 2016-2017. URL: http://land.gov.ua/wpcontent/uploads/2018/10/monitoring.pdf

19. Про затвердження Методичних рекомендацій $з$ розробки звіту з оцінки впливу на довкілля в галузі лісового господарства. Наказ Міністерства енергетики та захисту довкілля України від 02.03.2020 р. № 136. URL: https:// menr.gov.ua/documents/2749.html

\section{References:}

1. Dorosh, O. Fomenko, V. Kupriyanchik, I. and Svyrydova, L. (2019), "Financial and economic mechanism as a universal tool for translating land use into a model of sustainable development", Zemleustrij, kadastr i monitorynh zemel', vol. 2, pp. 13-22. doi: http://dx.doi.org/10.31548/ zemleustriy2019.02.02

2. Verkhovna Rada of Ukraine (2019), The Law of Ukraine " $n$ the Main Principles (Strategy) of the National Environmental Policy of Ukraine for the Period until the Year 2030", available at: https:// zakon.rada.gov.ua/laws/show/2697-19 (Accessed 15 Dec 2021).

3. Kasiukhnych, V.Yu. (2017), "Efficiency of use of natural resource potential of lands of forestry", Zbalansovane pryrodokorystuvannia, vol. 2, pp. 134-139.

4. Podlevs'ka, O.M. and Krasovs'ka, Yu.V. (2017), "Priorities of the national strategy of balanced development of Ukraine", Ekonomika i suspil'stvo, vol. 8, pp. 477-481, available at: https:/ /economyandsociety.in.ua/journals/8_ukr/82.pdf (Accessed 15 Dec 2021).

5. Piwowar-Sulej, K. (2021), "Core functions of Sustainable Human Resource Management. A hybrid literature review with the use of $\mathrm{H}$-Classics methodology", Sustainable Development, vol. 29, pp. 671-693. https://doi.org/10.1002/sd.2166 
6. Drebot, O.I. (2012), Instytutsionalizatsiia lisovoho sektora ekonomiky v konteksti staloho rozvytku: monohrafiia [Institutionalization of the forest sector of the economy in the context of sustainable development: a monograph], DIA, Kyiv, Ukraine.

7. Furdychko, O.I. Drebot, O.I. Palianychko, N.I. and Dan'kevych, S.M. (2020), "Instruments of the financial and economic mechanism of balanced use of forestry lands of Ukraine", Oblik i finansy, vol. 4 (90), pp. 144-157. https://doi.org/10.33146/ 2307-9878-2020-4(90)-144-157

8. Furdychko, O.I. Drebot, O.I. Palianychko, N.I. Dan'kevych, S.M. and Okabe, J. (2021), "Ecological and economic reporting as an indicator of the state of forestry land use", Agricultural and Resource Economics E-Journal, vol. 7, no. 2, pp. 219-250. https://doi.org/10.51599 /are.2021.07.02.12

9. Tretiak, A. Tretiak, V. Sakal, O. Kovalenko, A. Tretiak, N. and Shtogryn, H. (2020), "The value added chain in the mechanism of public-private partnership for the development of the land use economy of rural territories", Agricultural and Resource Economics, vol. 6, no. 3, pp. 112-134. https://doi.org/10.51599/are.2020.06.03.07

10. Johansson, J. and Ranius, Th. (2019), "Biomass outtake and bioenergy development in Sweden: the role of policy and economic presumptions", Scandinavian Journal of Forest Research, vol. 34 (8), pp. 771-778. doi.org/ $10.1080 / 02827581.2019 .1691645$

11. Karenlampi, P.P. (2021), "Capital Return Rate and Carbon Storage on Forest Estates of Three Boreal Tree Species", Sustainability, vol. 13, no. 12, 6675. https://doi.org/10.3390/su13126675

12. Sokil, O.H. (2018), Teoretyko-metodolohichni zasady bukhhalters'koho obliku staloho rozvytku sil's'kohospodars'kykh pidpryiemstv [Theoretical and methodological principles of accounting for sustainable development of agricultural enterprises], TOV "Kolor Prynt", Melitopol, Ukraine, available at: http://elar.tsatu.edu.ua/bitstream/123456789/8045/1/\%D0\%$9 \mathrm{C} \% \mathrm{D} 0 \% \mathrm{BE} \% \mathrm{D} 0 \% \mathrm{BD} \% \mathrm{D} 0 \% \mathrm{~B} 3 \% \mathrm{D} 1 \% 80 \% \mathrm{D} 0 \%-$ B0\%D1\%84\%D0\%B8\%D1\%8F \%D0\%A1\%D0\%$\mathrm{BE} \% \mathrm{D} 0 \% \mathrm{BA} \% \mathrm{D} 1 \% 96 \% \mathrm{D} 0 \% \overline{\mathrm{B}} \mathrm{B} \_2018 \% \mathrm{D} 0 \%-$ $905 \% 20 \% \mathrm{D} 1 \% 80 \% \mathrm{D} 0 \% \mathrm{~B} 5 \% \mathrm{D} 0 \% \mathrm{~B} 4 \% \mathrm{D} 0 \% \mathrm{~B}-$ $0 \%$ D0 \% B A \% D 1 \% 86\% D 0 B 8\%D 1\% 8 F.pdf (Accessed 15 Dec 2021).

13. Liubachyna, A. Secco, L. and Pettenella, D. (2017), "Reporting practices of State Forest Enterprises in Europe", Forest Policy and Economics, vol. 78, pp. 162-172. URL: https://doi.org/ 10.1016/j.forpol.2017.01.019
14. Bukvareva, E. Grunewald, K. Klimanova, O. Kolbovsky, E. Shcherbakov, A. Sviridova, T. and Zamolodchikov, D. (2021), "TEEB-Russia: Towards National Ecosystem Accounting", Sustainability, vol. 13, no. 12, 6678. https:// doi.org/10.3390/su13126678

15. Zamula, I. Tanasiieva, M. Travin, V. Nitsenko, V. Balezentis, T. and Streimikiene, D. (2020), "Assessment of the Profitability of Environmental Activities in Forestry", Sustainability, vol. 12, 2998. https://doi.org/10.3390/su 12072998

16. Cabinet of Ministers of Ukraine (2021), Resolution "On approval of the Methodology of normative monetary valuation of land plots", available at: https://www.kmu.gov.ua/npas/prozatverdzhennya-metodiki-normativnoyigroshovoyi-ocinki-zemelnih-dilyanok-1147031121/ (Accessed 15 Dec 2021).

17. FAO (2021), "Global Forest Resources Assessment 2020 - Main Report", available at: https://doi.org/10.4060/ca9825ru (Accessed 15 Dec 2021).

18. Nizalov, D. Dankevych, V. and Ivins'ka, K. (2018), "Monitoring of land relations in Ukraine: 2016-2017", available at: http://land.gov.ua/wpcontent/uploads/2018/10/monitoring.pdf (Accessed 15 Dec 2021).

19. Ministry of Energy and Environmental Protection of Ukraine (2020), Order "On approval of the Methodological recommendations for the development of the report on environmental impact assessment in the field of forestry", available at: https://menr.gov.ua/documents/ 2749.html (Accessed 15 Dec 2021).

Стаття надійшла до редакиї 20.12.2021 p.

\section{www. economy.nayka.com.ua}

Електронне фахове видання

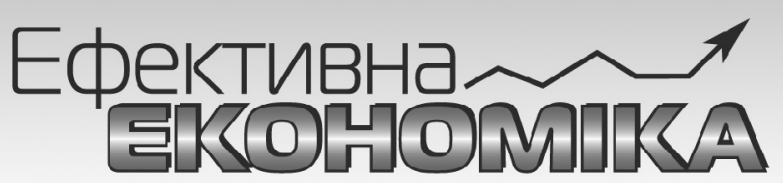

\section{Виходить 12 разів на рік}

Журнал включено до переліку наукових фахових
видань України з ЕкономІчниХ НАУк (Категорія “Б»)
Спеціальності - 051, 071, 072, 073, 075, 076, 292
e-mail: economy_2008@ukr.net
тел.: (044) 223-26-28
(044) 458-10-73


УAK 005.631.11: 004

Н. М. Горобець,

к. с.-г. Н., доцент, доцент кафедри менеАжменту і права, Аніпровський Аержавний аграрно-економічний університет

ORCID ID: 0000-0001-5032-2903

DOI: $10.32702 / 2306-6792.2022 .1 .36$

\title{
ЦИФРОВІ ТЕХНОЛОГІЇ В СИСТЕМІ СТРАТЕГІЧНОГО УПРАВАІННЯ АГРАРНИМИ ПІАПРИЕМСТВАМИ
}

\author{
N. Gorobets, \\ $\mathrm{PhD}$ in Agricultural Sciences, Associate Professor, Associate Professor of the Department \\ of Management and Law, Dnipro State Agrarian and Economic University \\ DIGITAL TECHNOLOGIES IN THE SYSTEM OF STRATEGIC MANAGEMENT \\ OF AGRICULTURAL ENTERPRISES
}

Статтю присвячено розгляду загальних аспектів використання цифрових технологій в системі стратегічного управління агроформуваннями. Встановлено, що розробка їх стратегій розвитку має грунтуватися на інформаційному забезпеченні бізнес-процесів. Аосліджено характерні умови, які потрібно враховувати в процесі розробки виробничої стратегії за умови цифровізації підприємств. Обгрунтовано доцільність прийняття управлінських рішень на підставі діджиталізації аграрного виробництва, що підвищить конкурентоспроможність сільськогосподарської продукції на ринку. Розроблено алгоритм впровадження цифрових технологій до стратегії підприємства, що включає визначення цілей управління новаціями, призначення відповідальних осіб, формування електронних документів, регламентування операцій тощо. Наведено методичні підходи до оцінювання ефективності впровадження цифрових технологій Ао виробничо-економічної діяльності аграрних підприємств. Визначено напрями стратегічного управдіння бізнес-процесами в аграрних підприємствах в результаті використання інформаційних технологій, що сприятиме формуванню цифрової агробізнес-екосистеми.

The article is devoted to the consideration of general aspects of the use of digital technologies in the system of strategic management of agricultural enterprises. It is established that the development strategy of agricultural enterprises should be based on information support of business processes. It is proved that the effectively developed mechanism of strategic management of agricultural enterprises under the condition of their digitalization mobilizes the use of scientific and technical, innovative, financial and economic, social and organizational potentials. Due to the introduction of precision farming technologies it is possible not only to obtain economic efficiency, but also to increase the efficiency of land use of the enterprise, region, country, resulting in increased production of useful agricultural products that will contribute to the health of the nation. Based on the data obtained through software products (computer technology), the costs of enterprises are reduced and the efficiency of their activities is improved. It is established that the creation of information support for agricultural producers based on modern computer and mobile technologies should be based on continuous digitalization and rural areas, training and retraining of agricultural workers, creating a system database, forming a single information space of agribusiness. An algorithm for the introduction of digital technologies in the production strategy of the enterprise has been developed, which includes defining the goals of innovation management, appointment of responsible persons, formation of electronic documents, regulation of operations. Methodical approaches to evaluating the effectiveness of digital technology implementation in agricultural enterprises are presented. The expediency of making 
management decisions on the basis of digitalization of agricultural production, which will increase the competitiveness of agricultural products on the market, is substantiated. The directions of strategic management of business processes in agricultural enterprises are determined on the basis of the use of information technologies, which will promote the formation of digital agribusiness ecosystem.

Ключові слова: чиррові технологіі, стратегічне управління, аграрні підприємтва. Key words: digital technologies; strategic management; agricultural enterprises.

\section{ПОСТАНОВКА ПРОБЛЕМИ}

За допомогою цифрових технологій стає можливим більш ефективно долати невизначеність ринкового середовища, управляти бізнес-процесами та досягати високої виробничої та економічної ефективності діяльності агроформувань. На сучасному етапі розвитку аграрної економіки діджиталізація сільськогосподарського виробництва $€$ пріоритетним напрямком під час формування стратегій розвитку сільськогосподарських підприємств. 3 метою покращання стратегічного управління бізнес-процесами все більше уваги приділяється використанню мережевих інструментів, які дають можливість аграріям формувати сприятливий інформаційний простір. Зокрема, аграрні підприємства, які користуються новітніми знаннями та технологіями здатні суттєво покращити власний соціально-економічний статус. Відтак впровадження цифрових інновацій до діяльності агропідприємств все більше стає необхідністю. 3 огляду на це, потрібно формувати цілісні структури баз даних про зовнішнє та внутрішнє середовище. Зокрема, агроменеджери за допомогою відповідного програмного забезпечення мають накопичувати інформацію про споживачів й, у такий спосіб, планувати найбільш оптимальні канали збуту, дані про постачальників, на підставі чого відбувається ухвалення найбільш ефективних логістичних рішень, розробляти товарну й цінову політику підприємства, досліджувати стан справ щодо конкурентного середовища, стратегічних партнерів, науково-технічних доробок та ін.

Суттєвою перепоною на шляху широкого введення інформаційного забезпечення стратегічного розвитку агропідприємств стає недостатність знань щодо комп'ютерної грамотності, а також практичного досвіду використання цифрових технологій. Між тим активний розвиток діАжиталізації аграрної сфери потребує нового підходу до розробки стратегій аграрного виробництва з урахуванням інформаційно-аналітичного забезпечення управління бізнес-процесами агроформувань.

За цих умов проблематика та актуальність статті обумовлена необхідністю досліджень у сфері інформаційного забезпечення стратегічного розвитку сільськогосподарських підприємств, зокрема, за рахунок використання цифрових технологій.

\section{АНАЛІЗ ОСТАННІХ ДОСЛІДЖЕНЬ}

Теоретико-методологічні засади стратегічного управління аграрними підприємствами на підставі інформаційного забезпечення розглядалися у наукових працях вітчизняних вчених, серед них - Р. Бруханський, Н. Васильєва, В. Гармашов, О. Гудзь, Г. Калетнік, В. Каплуненко, П. Коваленко, В. Мазур, $\Lambda$. Мармуль, М. Роӥк, М. Ромащенко, П. Саблук, О. Татаріко, С. Трибель та ін. Серед вчених, які грунтовно висвітлили використання цифрових технологій в агробізнесі: О. Вишневський, С. Коляденко, Е. Кривда, В. Аяшенко, М. Руденко, В. Фіщук та ін. На підставі досліджень науковців, встановлено, що активність впровадження діджиталізації до агропідприємств залежить від виявлення резервів щодо підвищення їх роботи, а також від рівня знань спеціалістів щодо володіння комп'ютерними технологіями.

Водночас недостатня вивченість процесу використання мережевих інструментів агротехнологій під час стратегічного управління виробничо-економічною діяльністю аграрних підприємств потребує подальших теоретичних та практичних досліджень.

\section{META CTATTI}

Метою статті $є$ визначення напрямів стратегічного управління бізнес-процесами в аграрних підприємствах на підставі використання інформаційних технологій, що сприятиме формуванню цифрової агробізнес-екосистеми.

\section{ВИКЛАД ОСНОВНОГО МАТЕРІАЛУ ДОСЛІДЖЕННЯ}

Цифрова трансформація аграрної сфери на сьогодні $€$ пріоритетним напрямком у загальній стратегії економічного зростання сільськогосподарської галузі. Інформаційні технології стають рушіями прогресу аграрного виробництва, формуючи єдину цифрову модель аграр- 
ного підприємства, що складається з інтеграції управлінської системи, організаційно-економічних відносин, технічних засобів та програмного забезпечення.

Враховуючи, що аграрне виробництво передбачає аналіз великого обсягу даних щодо агрономічної, технічної, економічної, хімічної, метеорологічної, біологічної та іншої інформації, агроменеджерам потрібно володіти цифровими компетенціями та навичками, на підставі чого розробляти найбільш оптимальні управлінські рішення, які б сприяли отриманню високої врожайності та прибутковості аграрних підприємств. Виконання робіт у сільському господарстві вже стає неможливим без використання інформаційних технологій, все більше залучається безкоштовних додатків до смартфонів та порталів, впроваджуються системи точного землеробства, активно застосовуються агродрони, технічні пристрої у вигляді біосенсорів, датчиків тощо.

Ефективно розроблений механізм стратегічного управління агропідприємствами за умови їх цифровізації мобілізує використання науково-технічного, інноваційного, фінансовоекономічного, соціального та організаційного потенціалу. Сфери застосування цифрових технологій стосуються: управління агровиробництвом; використання в галузях рослинництва, тваринництва; під час зберігання та переробки продукції; в процесах енергозабезпечення; у сільському соціумі. Так, у результаті впровадження технологій точного землеробства, можливо отримати не тільки економічну ефективність, але й підвищити коефіцієнт корисного використання земельного банку підприємства, регіону, країни, внаслідок чого очікується на зростання виробництва корисної аграрної продукції, що сприятиме оздоровленню нації.

Визначено, що системне та комплексне використання комп'ютерних програм таких як: PreAgri, ГIC 6 Агро, ГIC 6 ВЕБ та інші, дозволяє значно підвищити продуктивність праці, результативні показники виробничо-економічної діяльності підприємств. Стає можливим здійснювати функції 3 електронного ведення історії полів; управляти переміщенням техніки; віддалено здійснювати агротехнічні заходи; зчитувати дані метеостанцій; формувати ортофотоплани; здійснювати агрохімічний аналіз грунту та рослин; проводити супутникові зйомки, фото та відео-зйомки посівів [2].

На підставі досліджень обгрунтовано, що завдяки програмним продуктам досягається зниження витрат підприємств та покращують- ся показники ефективності їх діяльності. Так, за результатами розрахунків вчених, комплексна цифровізація агровиробництва дозволяє знизити витрати на $23 \%$, землекористування за допомогою технологій GPS навігації забезпечує середню економію витрат на рівні $11-14 \%$, диференційованого внесення мінеральних добрив - 8-12\%, використання систем паралельного водіння - 8-13\% [6].

Певні цифрові технології спрямовані на зменшення ризиків у сільськогосподарському виробництві, наприклад, використання безпілотних літальних апаратів дає змогу створювати докладні грунтові карти, проводити моніторинг стану пошкодження рослин, виявляти види та обсяг захворюваності сільськогосподарських культур, встановлювати поріг шкодо чинності тощо. За допомогою локального моніторингу посівів можливо виявити ділянку агрокультур, що відстають від вегетаційної стадії розвитку, ліквідувати надмірне забур'янення шляхом точкового внесення гербіцидів, або локально обробити посіви інсектицидами, уражені сільськогосподарськими шкідниками, внести рідкі добрива тощо. Застосування дронів в аграрному виробництві має тенденцію до розповсюдження, так як спостерігається зростаючий попит на новітнє технічне оснащення підприємств. Відтак економічна ефективність використання мікроавіації обумовлена одержанням прибутку, який формується за рахунок збільшення врожайності, а також зниження собівартості вирощування сільськогосподарських культур шляхом зменшення витрат щодо використання пестицидів, води, паливномастильних матеріалів тощо [1].

На підставі аналізу роботи аграрних підприємств визначено, що за допомогою цифрових технологій досягається розв'язання проблематичних питань у виробничих процесах щодо вирощування агрокультур, а саме: втрати врожаю через недотримання технічних вимог та незадовільний стан покриття дороги. Окремої уваги потребує роль IТ-технологій щодо недопущення розповсюдження злочинних схем в агробізнесі. Незаконне збагачення за рахунок доступу до елеваторів можливо контролювати використовуючи GPS-трекери, лічильники насіння, датчики тощо. Так, під час посівної кампанії та після збору врожаю за допомогою цифрових технологій можливо запобігти крадіжкам шляхом установки міток, GPS-координат на комбайн і зерновоз, які розпізнають одна одну і тільки тоді відбувається вивантаження зерна. Також використання датчиків обліку рівня пального, проточних витра- 


\begin{tabular}{|c|c|c|c|}
\hline $\begin{array}{l}\text { Пошук нових } \\
\text { ідей, } \\
\text { технологій, } \\
\text { рішень }\end{array}$ & $\begin{array}{l}\text { Апробація } \\
\text { технологій на } \\
\text { контрольній } \\
\text { ділянці }\end{array}$ & $\begin{array}{l}\text { Застосування } \\
\text { технологї̈ в } \\
\text { масштабах } \\
\text { всього } \\
\text { підприємства }\end{array}$ & $\begin{array}{l}\text { Оцінка } \\
\text { ефекту та } \\
\text { окупності від } \\
\text { застосування } \\
\text { IT-технології }\end{array}$ \\
\hline
\end{tabular}

Рис. 1. Алгоритм впровадження цифрових технологій до виробничої стратегії аграрних підприємств

Ажерело: узагальнено на підставі [2; 5$]$.

томірів, датчиків заповнення бункера комбайна, лічильників насіння, ультразвукових сканерів, що реагують на глибину оранки поля, сканерів наповнення кузова зерновоза - ці технології унеможливлюють зловживання. Наразі необхідно зазначити про неможливість прямого підпорядкування спеціаліста з цифрових технологій керівникові сільськогосподарського підприємства, тільки таким чином можливо уникнути порушення правових норм.

Таким чином, ефективність використання наведених цифрових технологій під час стратегічного управління сільськогосподарськими підприємствами за рахунок швидкості та якості одержаних даних дозволить агроменеджерам формувати зростаючі прибутки, стійку й довготривалу конкурентоспроможність.

Встановлено, що створення системи інформаційної підтримки агровиробників на основі сучасних комп'ютерних та мобільних технологій має грунтуватися на суцільній цифровізації сільськогосподарських підприємств та сільських територій, навчанні й підвищенні кваліфікації сільськогосподарських працівників, створенні системної бази даних, формуванні єдиного інформаційного простору агробізнесу. 3 врахуванням зазначеного, доречним $€$ формування екосистем агропідприємців за допомогою електронних порталів та цифрових сервісів, які б мали мобільні додатки з інформацією про маркетплейси, постачальницькі мережі, канали збуту, наявність, цінову політику техніко-технологічних ресурсів, ринок трудових ресурсів, що спеціалізується на використанні цифрових агротехнологій тощо. В Україні у певних регіонах спілки фермерів, сільськогосподарські кооперативи, асоціації вже працюють на базі розроблених електронних платформ щодо продажу та купівлі аграрної продукції [3].

Водночас Ярмоленко Я.О. стверджує, що якісне цифрове охоплення аграрних підприємств на засадах кооперації, може відбуватися у таких середовищах:

1) інституційне середовище - нормативноправова база, культура організацій, етика агробізнесу;
2) віртуальне середовище - цифрові технології, відповідне програмне забезпечення, цифрові компетенції;

3) реальне середовище - агротоваровиробники, постачальники ресурсів, споживачі, інформаційно-комунікаційна інфраструктура у сільській місцевості, місцева громада [7].

На підставі кооперації агробізнесу при взаємодії інституційного віртуального та реального середовища стає можливим існування цифрового сільськогосподарського суспільства.

У той же час, стратегічний розвиток агропідприємств на думку Правдюк Н., має полягати у використанні концепції науково-обгрунтованого процесу постійно зростаючого обсягу інформації та знань шляхом традиційних і нових інструментів обробки та аналізу інформації на підставі сучасних технологій з метою одержання конкурентних переваг, а також формування ефективної товарної політики підприємств [5].

На підставі результатів досліджень встановлено, що підхід, орієнтований на управління бізнес-процесами аграрних підприємств, набуває більшої значущості саме під час використання інноваційних технологій. Відтак та підприємствах під час розробки стратегій необхідно формувати процесну модель щодо генерації ідей, освоєння і розповсюдження інновацій. Водночас потрібно мати певну алгоритмізацію процесів на підставі визначення цілей управління новаціями, призначення відповідальних осіб, формування електронних документів, регламентації операцій тощо.

Окреслено, що процес впровадження цифрових технологій до виробничо-господарської діяльності аграрних підприємств має відбуватися на безперервній та регулярній основі шляхом виконання послідовних етапів (рис. 1).

Під час генерування ідей щодо впровадження цифрової новації до управління процесами підприємства визначаються конкретні технології виробництва сільськогосподарської продукції та ухвалюються техніко-технологічні рішення 3 наступною апробацією на контрольних ділянках. У результаті підтвердженої 


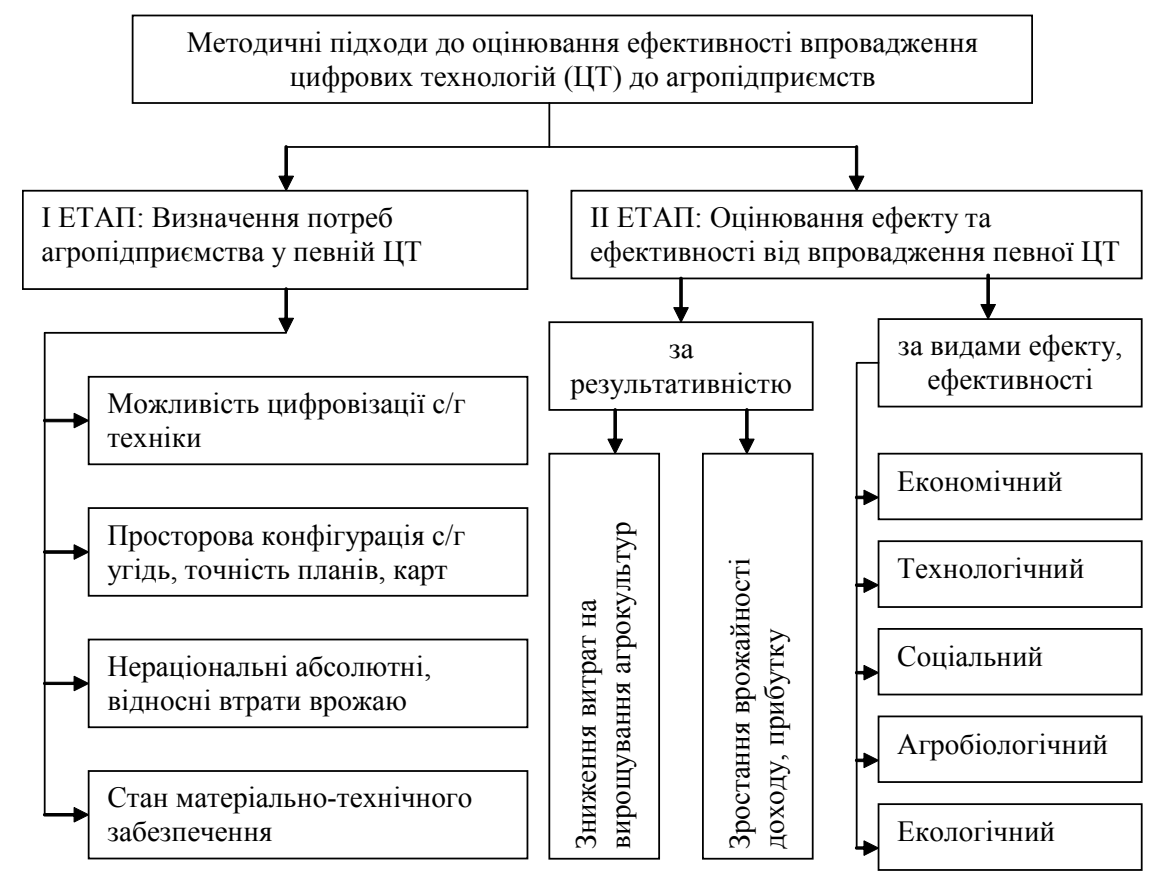

Рис. 2. Методичні підходи до оцінювання ефективності впровадження цифрових технологій до агропідприємств

Ажерело: узагальнено на підставі [4; 5].

ефективності використання IT-технології відбувається її масове впровадження, за отриманими результатами проводиться оцінювання окупності витрат на цифровізацію процесів.

На підставі оцінювання ефективності щодо впровадження цифрових технологій до агропідприємств визначають потребу в них, потенціал готовності щодо впровадження, ефект та ефективність діджиталізації. Так, Аушейко П.А. наводить методику оцінки ефективності інформаційних технологій на підприємствах агросектору, що складається 3 двох етапів. На першому етапі визначаються потреби та можливості щодо впровадження технологій на підставі аналізу якісної інформації, експертних оцінок та бази даних. Аругий етап включає кількісну оцінку ефективності впровадження обраних технологій [4].

Отже, оцінювання доцільності введення конкретної інформаційної технології до агропідприємств вкдючає з'ясування мождивостей аграрного підприємства шляхом аналізу ресурсної бази та стратегічної необхідності у новації, а після впровадження проводиться оцінювання отриманих результатів, ефекту та ефективності (рис. 2).

Методологія оцінювання ефективності впровадження цифрових технологій до стратегії виробничо-економічної діяльності аграрних підприємств, на думку вчених, по-перше, має грунтуватися на визначенні потреб і можливостей підприємства щодо необхідності їх використання за рахунок виявлення "вузьких" місць в існуючій виробничій програмі, технічних можливостей щодо цифровізації процесів, рівня матеріально-технічного забезпечення, наявності картографічного розташування полів, конфігурації посівних площ, меж ріллі, а також графіків сільськогосподарських робіт $[4 ; 5]$.

Окремої уваги заслуговує аналіз нераціональних агротехнологічних рішень менеджерів, внаслідок яких спостерігаються абсолютні та відносні втрати одержаного врожаю у порівнянні з плановими показниками. Необхідно зауважити на ступені ефективності використання добрив, пестицидів, технічних засобів, що оцінюється за допомогою порівняння показників агротехнічного рівня галузі рослинництва. Слід зазначити, що доцільність придбання цифрових технологій буде доведена в тому випадку, коли агропідприємство отримає високий показник ресурсоємності при низькому рівні врожайності сільськогосподарських культур. 3 огляду на такі позиції від агродіджиталізації виробництва можливо очікувати на підвищення віддачі від кожної одиниці вкладених ресурсів.

Під час впровадження конкретної цифрової технології, на другому етапі методології, відбувається визначення її результативності та ефективності. При цьому необхідно враховувати відповідність інноваційно-інформаційних систем та IT-технологій в агробізнесі сталому 


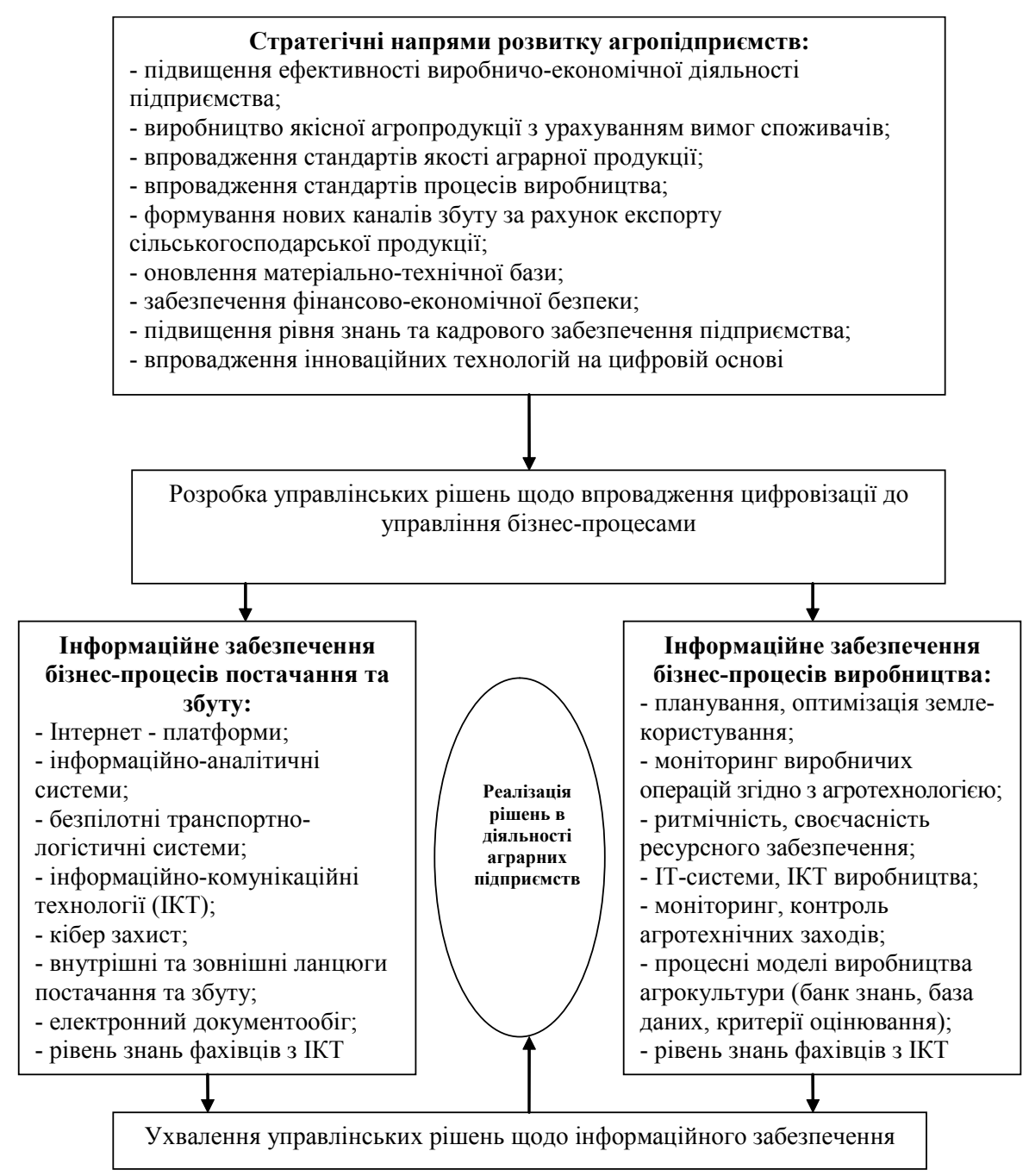

Рис. 3. Стратегічні напрями розвитку агропідприємств за умови цифровізації процесів

Ажерело: узагальнено на підставі $[2 ; 3 ; 6]$.

розвитку сільських територій на умовах: підвищення виробництва сільськогосподарської продукції; збереження природної родючості грунту; мінімізації негативного впливу на екологію; зростання якості життя мешканців сіл; розвитку об'єднаних територіальних громад; зміцнення продовольчої безпеки.

3 врахуванням зазначених умов від впровадження комп'ютерних технологій в агробізнесі можливо досягти певних ефектів та видів ефективності, зокрема, технологічний ефект досягається за рахунок зниження виробничих витрат, біологічний ефект формується шляхом зростання урожайності у порівнянні 3 попереднім сільськогосподарським роком до цифровізації та розраховується як відношення грошової виручки, одержаної внаслідок приросту урожайності, до витрат на впровадження ITтехнологій. Відтак економічна ефективність агропідприємства включатиме біологічний та технологічний ефект. Екологічної ефектив- ності можливо досягти за умови зниження або недопущення екологічних збитків за рахунок негативного впливу агротехнологічних заходів на стан грунтів, розвиток рослин, природні ресурси. Між тим, окремої уваги набуває ефект від збереження та відновлення природної родючості грунту, про що свідчитиме зміна змісту поживних речовин, а також зниження витрат на добрива, які необхідні для внесення. Соціальна ефективність утворюється внаслідок впливу цифрових технологій на доходи працівників підприємств, до того ж створюється бюджетний ефект, бо змінюється база оподаткування. Отже аналіз біологічної, економічної, соціально, технологічної та екологічної ефективності інноваційних стратегій дозволяє зробити висновок про необхідність формування системи витрат та результативності від впровадження інформаційних технологій не тільки в базових агропідприємствах, але й на регіональному рівні. 
Визначено, що розробка ефективного механізму управління бізнес-процесами агропідприємства має грунтуватися на синхронізації цифрових технологій зі стратегічним плануванням з урахуванням ресурсної бази, ринкових можливостей та обмежень. Удосконалення управління виробничими, маркетинговими, логістичними бізнес-процесами за рахунок впровадження інноваційних інформаційних технологій до стратегії підприємства сприятиме підвищенню активізації його внутрішніх можливостей та більш ефективному функціонуванню інформаційного простору екосистеми агровиробників. Внаслідок виконання таких умов можливий перехід аграрних формувань до якісно нового рівня функціонування.

3 метою окреслення стратегічного розвитку агропідприємств за умови впровадження цифровізації аграрного виробництва запропоновано комплекс об'єктно-орієнтованого інформаційного забезпечення управління бізнес-процесами (рис. 3).

Таким чином, під час впровадження цифрових технологій до стратегії діяльності сільськогосподарських підприємств необхідно оцінювати розвиток аграрного сектору в цілому, аналізувати нормативно-правове супроводження агровиробництва та цифровізації його бізнеспроцесів. Стратегічні напрями розвитку агробізнесу за умови його комп'ютеризації мають передбачати законодавчу підтримку, відповідну цифрову інфраструктуру сільської місцевості, усунення цифрових розривів у порівнянні 3 іншими секторами економіки, створення належних умов щодо використання мережевих інструментів, цифрову безпеку, наявність регуляторної підтримки інноваційно-інвестиційного розвитку підприємств тощо.

Водночас економічно доцільно, щоб планування показників роботи підприємств відштовхувалося від концептуальних напрямів щодо мінімізації витрат, максимізації прибутку, оптимізації процесів, зниження трудомісткості операцій, підвищення продуктивності сільськогосподарського виробництва за рахунок збільшення кількості та якості врожаю, зменшення шкідливого впливу на навколишнє середовище, зниження залежності від людського чиннику тощо.

У процесі прийняття виробничих рішень потрібно узгоджувати інформацію між різними об'єктами: поле, грунт, сільськогосподарські культури, збудники хвороб, популяції комах, шкідників, техніка, безпілотні літальні апарати, супутникові дані, метеопрогноз, добрива, засоби захисту рослин. Аля цього засто- совується цифрова платформа аграрного підприємства, яка включає необхідні програмні продукти для якісного ухвалення остаточного управлінського рішення в рамках стратегії.

Таким чином, стратегічні напрями розвитку аграрних підприємств в сучасних умовах господарювання мають грунтуватися на їх потенційній готовності щодо впровадження цифрових технологій. За рахунок діджиталізації бізнес-процесів підприємств відбувається їх оптимізація та економія кількості матеріальнотехнічних та інших ресурсів, систематизація та групування даних, зменшення витрат, у тому числі, щодо накопичення і використання інформації, що забезпечує в довгостроковому прогнозі конкурентоспроможність агроформувань.

\section{ВИСНОВКИ}

Таким чином, прискорений розвиток діджиталізації в агробізнесі спонукає аграріїв швидко реагувати та бути більш гнучкими під час розробки стратегій подальшої виробничо-економічної діяльності сільськогосподарські підприємства. Впровадження до виробничих процесів новітніх досягнень обумовлює необхідність у вивченні сутності цифрових технологій, ознайомленню з практичним досвідом їх використання в умовах аграрного виробництва. Водночас ефективне та швидке просування IT-технологій до агробізнесу можливе за умови ініціативності та мотивації агровиробників, державній підтримці та інтегрованому стратегічному партнерстві на інноваційних заcaдax.

Подальші дослідження полягатимуть у вивченні стратегічного управління виробничими бізнес-процесами в системі точного землеробства на підставі результатів використання конкретних цифрових технологій у галузі рослинництва аграрних підприємств.

\section{Мітература:}

1. Горобець Н.М., Чорна I.А. Використання безпілотних літальних апаратів в системі стратегічного управління аграрними підприємствами. Напрями розвитку ринкової економіки: нові реалії та можливості в умовах інтеграційних процесів: зб. тез доп. Міжнар. наук.-практ. конф., м. Ужгород, 30 листоп. 2019 р. Ужгород, 2019. C. 82-85.

2. Горобець Н.М. Напрямки діджиталізації аграрного виробництва. Economy, finance, law: current problems and development prospects: collective monograph. Anisiia Tomanek OSVC. Prague Czech Republic. 2020. Pp. 5-15. URL: 
https://www.inter-nauka.com/uploads/public/ 16160784832063.pdf (дата звернення: 11.12.2021).

3. Горобець Н.М., Хомякова А.О., Стариковська А. О. Перспективи використання цифрових технологій в діяльності аграрних підприємств. Ефективна економіка. 2021. № 1. URL: http://www.economy.nayka.com.ua/ ?op=1\&z=8521 (дата звернення: 02.12.2021).

4. Аушейко П.А. Методичні підходи до оцінки ефективності впровадження цифрових технологій в АПК. Молодіжна наукова ліга: теоретичне та практичне застосування результатів сучасної науки: зб. тез доп. Міжнар. наук.практ. конф., м. Запоріжжя, 27 листоп. 2020 р. Запоріжжя, 2020. T. 1. C. 37 - 39. URL: file:/// C:/Users/User/AppData/Local/Temp/6198$\% \mathrm{D} 0 \% \mathrm{~A} 2 \% \mathrm{D} 0 \% \mathrm{~B} 5 \% \mathrm{D} 0 \% \mathrm{BA} \% \mathrm{D} 1 \% 81 \% \mathrm{D} 1 \% 82 \%-$ $20 \%$ D $1 \% 81 \%$ D $1 \% 82 \%$ D $0 \%$ B $0 \%$ D $1 \%-$ $82 \% \mathrm{D} 1 \% 82 \% \mathrm{D} 1 \% 96-11565-1-10-20201130 . \mathrm{pdf}$ (дата звернення: 15.12.2021).

5. Правдюк Н.А. Інформаційне забезпечення стратегічного розвитку аграрних підприємств. Економіка, фінанси, менеджмент: актуальні питання науки і практики. 2021. № 2. C. 49-63. URL: http://efm.vsau.org/storage/ articles/July2021/wT3naGj1ZEBqupzNiOub.pdf (дата звернення: 10.12.2021).

6. Свиноус I.В., Гаврик О.Ю., Ткаченко К.В., Микитюк А.M., Семисал А.В. Сучасний стан та проблеми впровадження цифрових технологій в практику діяльності сільськогосподарських підприємств. Інвестиції: практика та досвід. 2020. № 15-16. С. 35-39. DOI: 10.32702/23066814.2020.15-16.35 (дата звернення: 10.12.2021).

7. Ярмоленко Я.О. Програма створення цифрової платформи для кооперації та балансування аграрного виробництва. Ефективна економіка. 2019. № 1. URL: http://www.economy.nayka.com.ua/pdf/1_2019/63.pdf(дата звернення: 15.12.2021).

References:

1. Gorobets, N.M. and Chorna, I.A. (2019), "The use of disembodied aircraft in the system of strategic management of agricultural industries", Napriamy rozvytku rynkovoi ekonomiky: novi realii ta mozhlyvosti $\mathrm{v}$ umovakh intehratsijnykh protsesiv: zb. materialiv dop. uchasn. Mizhnar. nauk.-prakt. konf. [Directions of market economy development: new realities and opportunities in the conditions of integration processes. International. scientific-practical conf.], Vid. dim "Gel'vetika", Uzhgorod, Ukraine, 30 nov, pp. 82-85.

2. Gorobets, N.M. (2020), "Directions of digitalization of agricultural production", Economy, finance, law: current problems and development prospects: collective monograph, Anisiia Tomanek OSVC, Prague, Czech Republic, pp. 5-15.

3. Gorobets, N., Homjakova, D. and Starikovs'ka, D. (2021), "Prospects for the use of digital technologies in the activities of agricultural enterprises", Efektyvna ekonomika, [Online], vol. 1, available at: http://www.economy.nayka.com.ua/?op $=1 \& z=8521$ (Accessed 2 December 2021).

4. Dushejko, P.A. (2020), "Methodical approaches to assessing the effectiveness of digital technologies in agriculture", Molodizhna naukova liga: teoretichne ta praktichne zastosuvannja rezul'tativ suchasnoï nauki [Youth Scientific League: theoretical and practical application of the results of modern science], Zaporizhzhja, Ukraine, 27 nov, vol. 1, pp. 37-39.

5. Pravdjuk, N.L. (2021), "Information support of strategic development of agricultural enterprises", Ekonomika, finansi, menedzhment: aktual'ni pitannja nauki i praktiki, vol. 2, pp. 49-63.

6. Svinous, I.V., Gavrik, O.Ju., Tkachenko, K.V., Mikitjuk, D.M. and Semisal, A.V. (2020), "Current state and problems of introduction of digital technologies in the practice of agricultural enterprises", Investiciï: praktika ta dosvid, vol. 1516, pp. $35-39$.

7. Jarmolenko, Ja. O. (2019), "Program to create a digital platform for cooperation and balancing agricultural production", Efektyvna ekonomika, vol. 1, available at: http://www.economy.nayka.com.ua/pdf/1_2019/63.pdf (Accessed 6 December 2021).

Стаття надійила до редакцї 04.01.2022 p.

www. economy.nayka.com.ua

Електронне фахове видання

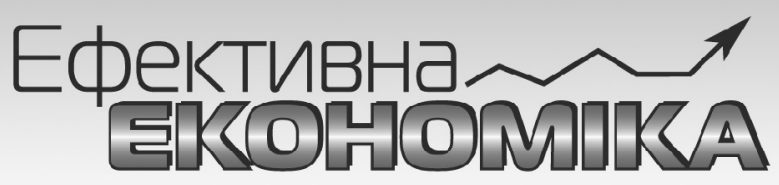

Виходить 12 разів на рік

Журнал включено до переліку наукових фахових видань України з ЕКОНОМІЧНИХ НАУК (Категорія “Б»)

Спеціальності - 051, 071, 072, 073, 075, 076, 292

e-mail: economy_2008@ukr.net тел.: (044) 223-26-28

(044) $458-10-73$ 
UDC: 330.3

\title{
V. Boskova,
}

Applicant of the first (bachelor's) level of higher education in the specialty "Economics", Kherson Branch of Admiral Makarov National University of Shipbuilding, Kherson, Ukraine ORCID ID: 0000-0002-2076-5866
A. Rusnak,
Doctor of Economic Sciences, Professor, Professor of the Department of Economics, Kherson Branch of Admiral Makarov National University of Shipbuilding, Kherson, Ukraine ORCID ID: 0000-0002-3198-2866

\section{Nadtochii,}
Doctor of Economic Sciences, Associate Professor, Professor of the Department of Economics, Kherson Branch of Admiral Makarov National University of Shipbuilding, Kherson, Ukraine ORCID ID: 0000-0003-0693-8000

\section{THE ESSENCE OF BUSINESS-PROCESSES AND PROCESS-ORIENTED MANAGEMENT IN AGRICULTURAL ENTERPRISES}

\author{
В. В. Боскова, \\ здобувач першого (бакалаврського) рівня вищої освіти за спеціальністю "Економіка", Херсонська \\ філія Національного університету кораблебудування імені адмірала Макарова, м. Херсон, Україна \\ А. В. Руснак, \\ А. е. н., професор, професор кафедри економіки, Херсонська філія Національного університету \\ кораблебудування імені адмірала Макарова, м. Херсон, Україна \\ I. I. Надточій, \\ А. е. н., доцент, професор кафедри економіки, Херсонська філія Національного університету \\ кораблебудування імені адмірала Макарова, м. Херсон, Україна
}

\section{СУТНІСТЬ БІЗНЕС-ПРОЦЕСІВ ТА ПРОЦЕСНО-ОРІЕНТОВАНОГО УПРАВАІННЯ У СІАЬСЬКОГОСПОААРСЬКИХ ПІАПРИЄМСТВАХ}

The article describes four main approaches in enterprise management: historical, functional, systemic, situational It has been determined that the process approach allows to take into account such important aspects of the business as the focus on the final product, the interest of each performer in improving the quality of the final product and, consequently, interest in completing the work. The essence of the category "business-process" has been investigated. The main elements of the structure of the business-process of an agricultural enterprise have been identified and characterized: the owner responsible for its implementation; input; output; management and resources. The distinctive features of the businessprocess of agricultural enterprises have been generalized. Based on this, the business-process of an agricultural enterprise has been defined as a set of successive technologically interconnected operations that use industry-specific resource planning as input and the organization of actions to solve problems as output, applying controlling principles that create products that play strategic role in the livelihood of society and is of value to consumers. The classification of businessprocesses of agricultural enterprises is given and their main types are characterized: business-processes of production or main processes, auxiliary or service business-processes, providing business-processes and development businessprocesses. It has been proved that the management of business-processes of agricultural enterprises has its own specifics due to the peculiarities of agriculture. The main advantages of process-oriented management of agricultural enterprises have been highlighted. It has been determined that in order to build an effective business-process management system of agricultural enterprises it is necessary to take into account the interaction of three main elements - key business-processes, enterprise subsystems and types of consumers. When building such a system, it is necessary to take into account industry specifics, the presence of a formalized strategy and long-term planning, the size of the enterprise, as well as the impact of macroeconomic factors. 
У статті охарактеризовано чотири основні підходи в управлінні підприємством: історичний, функціональний, системний, ситуаційний. Визначено, що процесний підхіА дозволяє врахувати такі важдиві аспекти бізнесу, як орієнтація на кінцевий продукт, зацікавленість кожного виконавця у підвищенні якості кінцевого продукту і, як наслідок, зацікавленість у кінцевому виконанні роботи. Аосліджено сутність категорії "бізнес-процес". Визначено та охарактеризовано основні елементи структури бізнес-процесу сільськогосподарського підприємства: власник, відповідальний за його виконання; вхіА; вихіА; управління та ресурси. Узагальнено характерні риси бізнес-процесу сільськогосподарських підприємств. На основі цього бізнес-процес сільськогосподарського підприємства визначено як сукупність послідовних технологічно взаємопов'язаних операцій, що використовують на вході планування ресурсів, зумовлених специфікою галузі, та організацію дій з вирішення завдань, на виході, застосовуючи принципи контролінгу, що створюють продукцію, яка відіграє стратегічну роль у життєзабезпеченні суспільства та становить цінність Аля споживачів. Наведено класифікацію бізнес-процесів сільськогосподарських підприємств та охарактеризовано їх основні види: бізнес-процеси виробництва або основні, допоміжні або обслуговуючі бізнес-процеси, забезпечуючі бізнеспроцеси і бізнес-процеси розвитку. Аоведено, що управління бізнес-процесами сільськогосподарських підприємств має власну специфіку, яка зумовлена особливостями сільського господарства. Виділено основні переваги процесноорієнтованого управління сільськогосподарськими підприємствами. Визначено, що Аля побудови ефективної системи управління бізнес-процесами сільськогосподарських підприємств необхідно враховувати взаємодію трьох основних елементів - ключових бізнес-процесів, підсистем підприємства та видів споживачів. При побудові такої системи необхідно врахувати галузеві особливості, наявність формалізованої стратегії та довгострокового планування, розмір підприємства, а також вплив макроекономічних чинників.

Keywords: business process, process approac, management, organization, agricultural enterprise.

Ключові слова: бізнес-прочес, прочесний підхід, управління, організачіл, сільськогосподарське підприємство.

\section{FORMULATION OF THE PROBLEM}

Current trends in Ukraine's economy, intensification of market competition require agricultural enterprises to increase their competitive potential by introducing innovative methods and approaches to management practices that can quickly respond to changes in the external environment. At the same time, managers of agricultural enterprises and rural entrepreneurs focus on improving the technology of agricultural production, mostly ignoring the new approaches in management.

Improving of business-processes is one of the main tools for improving the efficiency of entrepreneurial activity. This is primarily due to increased competition from foreign producers, as well as high dynamics of business environment development. Therefore, for managers of agricultural enterprises an important task is to form a mechanism for improving business-processes, which allows to adapt the management system to changes in the external environment in undetermined conditions, which ensures their high efficiency and competitiveness. In this regard, the issues of improving the management of business-processes of agricultural enterprises and improving the efficiency of their activity on the basis of effective process management are important and relevant.

By managing processes and constantly improving them, the company achieves high efficiency of its activities. That is why the process-oriented approach to enterprise management has become the basis of quality management system standards, designed based on the world experience of leading companies. Business-process management helps to reduce downtime, optimize the use of resource potential, reduce financial costs, improve the efficiency of the organization and the quality of enterprise functioning, increase staff motivation. A process-oriented approach to enterprise management allows to accurately determine the ultimate goals and results of the enterprise, and helps to identify the contribution of each employee in achieving these results.

\section{ANALYSIS OF RECENT RESEARCH AND PUBLICATIONS}

The theoretical and methodological basis of the research in the field of management are the works of foreign scientists I. Ansoff, E. Deming [1], P. Drucker, P. Kaplan, A. Marshall, M. Mescon, M. Porter [2], F. Taylor [3] and others. J. Brocke [4], T. Davenport [5], M. Zairi [6], S. Zelt [4], V. Eliferov [7], K. Loginov [8], Y. Oikhman [9], E. Popov [9], J. Recker [4], V. Repin [7; 10; 11], M. Hammer [12], J. Champy [12], T. Schmiedel [4], J. Short [5] devoted their works to the problems of application of the process approach in the management of organizations. Issues of business-process management of agricultural enterprises are reflected in the works of such domestic scientists as A. Zheleznyak, I. Ivanytsky [13], T. Yavorska [14] and others. 
Table 1. The main approaches in enterprise management

\begin{tabular}{|l|l|}
\hline Approaches & \multicolumn{1}{|c|}{ Characteristic } \\
\hline Historical & $\begin{array}{l}\text { Is based on highlighting different schools of thought, } \\
\text { namely: a) scientific management; b) administrative } \\
\text { management; c) human relations and the science of } \\
\text { behavior; d) management science or quantitative methods }\end{array}$ \\
\hline Functional & $\begin{array}{l}\text { Management is seen as a continuous series of interrelated } \\
\text { management functions: planning, organization, motivation, } \\
\text { control }\end{array}$ \\
\hline Systemic & $\begin{array}{l}\text { The organization is perceived as a system of } \\
\text { interdependent elements, such as people, structure, tasks } \\
\text { and technology, which are aimed at achieving certain goals } \\
\text { in a changing environment }\end{array}$ \\
\hline Situational & $\begin{array}{l}\text { Concentrates on the fact that the suitability of different } \\
\text { management methods is determined by the specific } \\
\text { situation. Because there is such a variety of factors and } \\
\text { their combinations that determine the situation, both in the } \\
\text { organization and in the external environment, there is no } \\
\text { single "best" method of managing the organization. The } \\
\text { most effective method in a particular situation is the } \\
\text { method that best suits that situation }\end{array}$ \\
\hline Process & $\begin{array}{l}\text { All activities of the company are perceived as a network of } \\
\text { interacting processes that take place within the } \\
\text { organizational structure of the company and implement the } \\
\text { purpose of its existence }\end{array}$ \\
\hline
\end{tabular}

However, the analysis of the existing theoretical basis of the research topic shows that the theoretical, methodological and practical developments related to the management of agricultural enterprises based on the improvement of business-processes are not yet sufficiently studied. This problem is relevant for various branches of agricultural production.

\section{FORMULATION OF THE GOALS OF THE ARTICLE}

The purpose of the study is to substantiate and develop theoretical aspects to improve the management of business - processes in agricultural enterprises, which contribute to improving the efficiency of their activities.

\section{PRESENTATION OF THE MAIN MATERIAL OF THE STUDY}

Recent decades have been marked not only by the rapid development of machinery and technology, but also by a qualitatively new level of doing business. Problems of effective management of agricultural enterprises come to the fore, methods and management tools of business are being improved. Therefore, the issue of creating an effective management system capable of ensuring the competitiveness of enterprises and the production output corresponding to world counterparts is acute for managers. Customeroriented approach is becoming more widespread, producers and services are changing their behavior in the market and moving from increasing production and sales to maximum customer satisfaction. In these conditions, the use of process- oriented enterprise management system provides tangible benefits, as the system of interdependent and interacting business-processes has the ultimate goal - to create goods or services that are valuable to external and internal consumers.

At this stage of development of theory and practice there are four main approaches to management: historical, functional, systemic, situational (Table 1).

The basis of process management - a complex but effective approach to managing the organization - are business-processes. The process approach is an effective lever of management, it allows to reduce overhead costs and improve product quality, obtain comprehensive information about the current state of business and timely make strategically sound management decisions. Modern theoretical and methodological approaches, such as quality management, optimization and engineering of business-processes, benchmarking, balanced scorecard, etc., as well as a number of information technologies can be fully used only if the process management of the organization is applied.

Process-oriented management has replaced the functional one, which considers the construction of the organization by functions and levels of hierarchy. This organization of management is based on the principle of consistent performance of labor operations, i.e., the labor task is divided into separate operations (tasks, stages), and each employee specializes in performing one of them [3].

The transition to process management allows to identify priority processes that should be improved and developed in order to strengthen the competitive advantage of the enterprise.

The process approach allows to take into account such important aspects of the business as the focus on the final product, the interest of each performer in improving the quality of the final product and, consequently, the interest in completing the work. Processes are the basis of any organizational system and at the same time act as a kind of indicator of the efficiency of economic activity of the organization and its competitiveness. In order to ensure the sustainable and efficient functioning of the enterprise in the long run, it is necessary to constantly improve the businessprocesses carried out on it.

For the first time, the concept of businessprocess was introduced by $\mathrm{M}$. Hammer and J. Champy in the monograph "Reengineering the Corporation: A Manifesto for Business Revolution". They defined a business-process as a set of different activities in which one or more types of 
resources are used as the "input", and as a result of this activity, a product that has value for the consumer is created at the "output" [12].

T. Davenport and J. Short consider the business-process as a set of logically interrelated actions performed to achieve a certain outcome of business activities; structured finite set of actions that are designed for a specific service (product) for a particular consumer or market; specifically ordered set of works, tasks in time and space, indicating the beginning and the end, the exact definition of inputs and outputs; a structured, measurable set of actions designed to make a specific output for a particular customer or market [5]. M. Porter defined the business-process as an entity defined by entry and exit points, interfaces and organizational devices that partially contain the devices of the consumer of services (goods), where the value of the service (goods) is being increased [2]. According to E. Deming, business-processes are any activities in the work of the organization [1]. According to $\mathrm{K}$. Loginov, business-process is a change in the object of the process by transforming material and/ or information flows carried out by functional subjects of the process on a particular technology with the ultimate goal of creating new consumer value or bringing consumer value to the consumer [8]. V. Repin and V. Eliferov give the following definition of the business-process: "a stable, purposeful set of interrelated activities, which, using a certain technology, turns the inputs into outputs that are of value to the consumer" [7]. E. Oikhman and E. Popov define businessprocesses as many internal steps (types) of activities that begin with one or more inputs and end with the production of products required by the customer and satisfy him in cost, durability, service and quality; or as a complete flow of events in a system that describes how a customer starts, runs, and finishes interaction with a business [9]. A business-process is a series of interrelated activities that transform inputs (orders and products) and outputs (products or services) in a given time interval to achieve a specific goal. One of the main differences between a business process and a simple process is its business orientation, i.e. the reflection of economic activity of the enterprise, the result of which is usually a profit $[15$, p. 7]. Business-processes are a systematic and consistent execution of functional operations that bring a specific result [16].

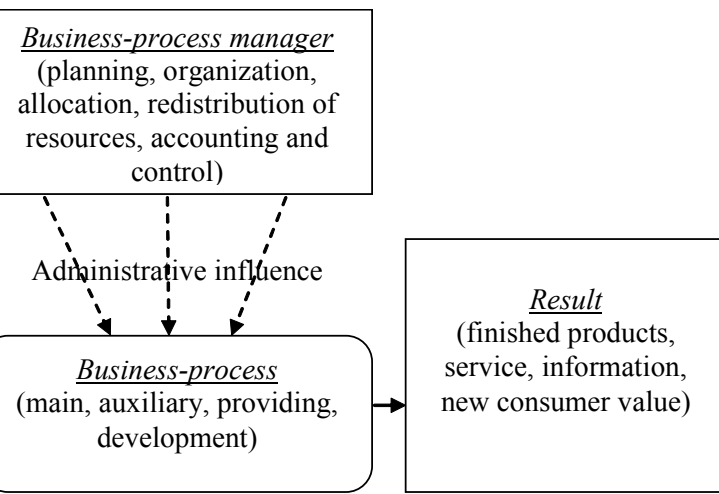

enterprise

Table 2. Basic elements of the business-process structure

\begin{tabular}{|l|l|}
\hline \multicolumn{1}{|c|}{ Element } & \multicolumn{1}{c|}{ Characteristic } \\
\hline Process owner & $\begin{array}{l}\text { An official or a collegiate management body that has the } \\
\text { resources needed to execute the process and is } \\
\text { responsible for the result of the process }\end{array}$ \\
\hline Input & $\begin{array}{l}\text { Material or information used or converted into a } \\
\text { business-process to produce a result (output) }\end{array}$ \\
\hline Output & Product or information produced by a business-process \\
\hline Management & $\begin{array}{l}\text { Rules, technologies, procedures or standards by which a } \\
\text { business-process is guided }\end{array}$ \\
\hline Resources & $\begin{array}{l}\text { A material or information object that is constantly used } \\
\text { to perform the process but is not an input of the process }\end{array}$ \\
\hline
\end{tabular}

In the above authors' definitions $[7 ; 8 ; 12]$ of the category "business-process" the greatest emphasis is placed on the fact that the output is products that have value for consumers, so business-processes are always focused on customer needs. Other authors emphasize the formation of new (added) value at the end of the businessprocess [2].

However, these definitions of "businessprocess" are best suited to enterprises that produce industrial goods, provide consulting or IT services. Therefore, in our opinion, to determine the essential differences of the category "businessprocess of an agricultural enterprise" it is necessary to clearly define the main elements of the businessprocess in agriculture.

The business-process of an agricultural enterprise, like any process, consists of the following basic elements: the owner responsible for its implementation; input; output; management and resources (Fig. 1).

The characteristics of the basic elements of the business-process structure are given in Table 2.

The process owner manages the process and is an integral part of the process [12]. It is allowed that a business-process may not have an input. It should be noted that a business-process without a result has no sense.

The result of the business-process can be: finished products, service, information, new 
Table 3. Classification of business-processes of agricultural enterprises

\begin{tabular}{|c|c|}
\hline $\begin{array}{c}\text { Type } \\
\text { of business- } \\
\text { processes }\end{array}$ & List \\
\hline $\begin{array}{l}\text { Main } \\
\text { (production) }\end{array}$ & $\begin{array}{l}\text { - in the field of crop production (cultivation of cereals and } \\
\text { legumes, industrial crops, fodder, vegetables, melons, stone } \\
\text { fruit, berry crops; production of varietal seeds); } \\
\text { - in the field of animal husbandry (breeding of cattle, pigs, } \\
\text { sheep and goats, rabbits, poultry, fish, horses, bees) }\end{array}$ \\
\hline $\begin{array}{l}\text { Auxiliary } \\
\text { (service) }\end{array}$ & $\begin{array}{l}\text { - equipment repair and maintenance; } \\
\text { - agrochemical service; veterinary and zootechnical services; } \\
\text { - maintenance of technological equipment; } \\
\text { - storage and finalization of products; } \\
\text { - transport service }\end{array}$ \\
\hline Development & $\begin{array}{l}\text { - introduction of innovative communication technologies of } \\
\text { management; } \\
\text { - introduction of resource-saving, knowledge-intensive } \\
\text { technologies; } \\
\text { - modernization of technological lines, equipment, buildings, } \\
\text { premises, storage facilities; } \\
\text { - introduction of high-yielding varieties of agricultural crops } \\
\text { and highly productive breeds of farm animals }\end{array}$ \\
\hline Providing & $\begin{array}{l}\text { - quality system; } \\
\text { - purchases; } \\
\text { - sales; } \\
\text { - staff; } \\
\text { - finance }\end{array}$ \\
\hline
\end{tabular}

create products that play a strategic role in life-supporting of a society and are of value for consumers.

The process approach is extremely promising in terms of modern management theories, however, it should be taken into account that only a comprehensive consideration of all defining factors can lead to the desired result, so we agree with the opinion of scientists [10] that the process approach should be considered jointly with many other decisive factors: structural, financial, personnel, etc.

Most often, the business-processes are visualized using a block diagram of businessprocesses. The technology of the description of business-processes should ensure the transparency of all business operations, which will allow to continually analyze the possible consequences of failures in one or another stage of execution of works, to find and fix the error in a timely manner. Particular attention in the analysis is paid to managing operating consumer value, etc. The resources of the process may include: information, staff, equipment, software, infrastructure, environment, transport, communication, etc. The owner of the process during planning and management of the process carries out allocation and redistribution of resources to achieve the best results of the process. Information can simultaneously refer to the inputs and resources of the process.

For an agricultural enterprise, the features of the business-process are:

- sequence of technologically interconnected actions;

- as resources used at the input and participating in further transformation and development, can be living organisms (working and productive livestock, plants), immobile resources (land), at the output they can reduce or increase their quality;

- "Result" - products received at the output are: a resource used at the input to another business-process; the subject of vital necessity, and which is especially important, the products have a strategic significance, since it maintains the food security of the country from which the quality of life support depends directly.

In this regard, relating to agricultural production, the following definition will be more precise: the business-process of an agricultural enterprise is a set of consistent technologically interconnected operations, which at the input use industry-specific resource planning, and organization of actions for solving tasks, at the output, applying the principles of controlling, expenses, which is one of the main conditions of survival on the market.

In practice, business-processes are usually determined based on the needs of key customers. It is important to provide unimpeded implementation of the process, which will allow the company to increase the added value and maximize the usefulness and value of products and services for its own clients [11].

The business-processes identification and classification at an agricultural enterprise is expedient to perform with a specially formed team, which must necessarily include: heads of departments, specialists who know the problems and technology of the enterprise, and it is desirable to include in a process team and external consultants.

The basis of business-processes classification is four basic categories: main business-processes; providing business-processes; development business-processes; management business-processes.

Specific traits of main business-processes are: processes that create an added value of a product which is produced in a company; processes that create a product which is valuable for external customers; processes the main aim of which is a profit; processes external customers are ready to pay for [12].

An important feature in the classification of business-processes of agricultural enterprises should be noted. Management business-processes are quite difficult to distinguish in isolation from the industry or a particular type of product, so it is advisable to distinguish business-processes of 
production or main processes, auxiliary or service business-processes, providing business-processes and development business-processes (Table 3).

The basis for business-processes classification and identification in agricultural enterprises should be the sectoral division. Thus, the (main) production processes can be divided into businessprocesses in crop production and animal husbandry. The main business-processes of agricultural enterprises also include: agricultural production, enterprise resource management, enterprise finance management, design of the structure of sown areas and livestock, stock management, formation of sales and marketing policy, implementation of quality control system for agricultural products [13, p. 119].

Auxiliary or service business-processes in agricultural enterprises are processes that do not create products, but affect their quality, ensuring timely and flawless implementation of main processes (equipment and technical means repair and maintenance; provision of all types of energy, transportation, storage, services (chemical, veterinary, zootechnical services) In agricultural enterprises, auxiliary business-processes accompany the work of the main processes, namely to meet the production needs of the main agricultural industries (crop and livestock), performing work for them and providing services. Auxiliary business-processes of agricultural enterprises are: agricultural infrastructure management, personnel management, business risk management, information management, legal support management, etc. [13, p. 119].

Development business-processes include the processes of improving the product or service, technology, equipment, and innovation processes. Development business-processes are investment activities where efforts are made today and results are obtained after a certain period. The following business-processes are providing: administrative and economic management, legal support, etc. In contrast to the main processes, number of providing processes reaches several dozen. For agricultural enterprises, we distinguish the providing (management) business-processes that cover the full range of management functions both at the level of departments and organization level in general.

In order to achieve the set goals and defined tasks, as well as to ensure the smooth and flawless execution of any business-process, it is necessary to form a business-process management system in the organization. Business-process management is a comprehensive approach to the implementation of effective business-processes in the organization, which aims to increase the efficiency of organi- zational processes by improving them and implementing innovations [4]. T. Yavorska defines the management of business-processes in the enterprise as an approach to management, focused on optimizing the ways of doing business-processes in organizations [14]. Business-process management is defined as the organization's efforts to analyze and continuously improve production, marketing, communications and other key elements of the company [6].

Using a systems approach to reveal the essence of the category of "business-process management", management is seen as an impact on the system in order to bring it to the desired state. In this case, the system or object of management will be the business-process of the agricultural enterprise, which includes certain consistent, interconnected actions determined by the technology used in the process and the time spent on each operation.

The subject of business-process management is the manager. A term "the owner of process" is often found in the specialized literature. But a more accurate term is "process manager", that performs all the functions of process management and is responsible for achieving the planned results. Individual business-process managers need to be coordinated by a senior manager to achieve the goal more quickly and efficiently.

The management structure is an important element in the business-process management system which should also be defined. In an agricultural enterprise, several subdivisions take part in each business-process, which are differentiated depending on the functional orientation and costs: labor, material, money. Therefore, the structure of business-process management is created in accordance with the division of responsibilities and division of labor between managers, process managers by defining their tasks and powers arising from them. Thus, the structure reflects the relationship of subordination in the management of business-processes.

Management of business-processes of agricultural enterprises has its own specifics due to the peculiarities of agriculture.

1. Dependence on natural factors: soil and climatic conditions, bioclimatic potential of the management area, which determines the specialization of production and is a determining criterion in the selection of business-processes.

2. The main means of production in agriculture is land, the productivity of which depends on fertility. Soil fertility can be maintained in its natural quality, deteriorated or improved, which must be taken into account when planning a production program. 
3. Created products in agricultural enterprises participate in the further production process (seeds and planting material, fodder, young cattle). Therefore, in production management it is important to strive not only to implement the sales plan and ensure revenue, but also to create the necessary natural resources for the next production cycle, which requires additional resources for the construction of premises and industrial facilities. Therefore, providing business-processes in the field of product storage become of great importance.

4. Seasonality of production, which is expressed in the uneven use of resources, sales and cash flow during the year. When planning and allocating business-processes, it is necessary to take into account this feature for optimal use of human resources.

5. The presence of a time interval between production and sale of agricultural products requires the creation of large reserve storages and refrigeration facilities and necessitates primary processing of products. Thus, in the main businessprocess it is necessary to allocate auxiliary business-processes related to the finalization of products. It is also important to plan and justify the amount of capacity required.

6 . Since much of the food is needed in a human diet every day, a large number of people are busy selling it, which significantly increases the share of labor costs not only in production but also in the whole chain of product promotion, from producer to end consumers. In this regard, it is necessary to organize cost accounting to distribute them in business-processes.

In our opinion, the successful implementation of plans for the development of agricultural enterprises is possible in an effective management system based on regulated processes. The process approach has clear advantages over the functional one. When building a process-oriented management system, the main emphasis is on the development of mechanisms of interaction within the process both between structural units within the enterprise and with the external environment, i.e., with consumers, suppliers and partners. It is the process approach that allows to take into account such important aspects of the business as the focus on the final product, the interest of each performer in improving the quality of the final product and, consequently, interest in completing the work.

When managing business-processes of agricultural enterprises, it is important to take a comprehensive approach to the implementation of the functions of planning, control, analysis and cost accounting, which is associated with: mutual influence of efficiency and effectiveness of businessprocesses on each other and on the competitiveness of the enterprise as a whole; the need to timely prevent and eliminate the causes of problems in the implementation of processes, and not solve those already arising with the help of administrative and regulatory measures; the emergence of most problems at the boundaries between business-processes in one classification group and between business-processes of different groups (this is due to the specifics of agricultural production, when one output is raw material at the input of another business-process).

The following main advantages of processoriented management of agricultural enterprises can be identified:

- business-process description technology ensures transparency of all operations not only in the technological chain, but also in structural units, which allows to predict the possible consequences of failures or violations at any stage of work;

- the process approach allows to unite separate actions of functional divisions and to direct their efforts on achievement of the uniform set goal, result;

- allows to increase the motivation of each participant in the process, delegating his powers and responsibilities, while managers are exempt from operational issues and pay more attention to solving strategic tasks;

- high flexibility and adaptability of the process management system, due to greater selfregulation and focus on the final result, taking into account the preferences of consumers and the interests of the enterprise;

- the ability to effectively manage operating costs.

It is important when building the structure of business-processes to prevent a formation of a process management system along with the existing system of functional and administrative management. In this case, the company will have two parallel management systems that must constantly coordinate decisions both in time and space. Two management systems (process and functional) will require two accounting and reporting systems, two resource allocation systems.

In this regard, one of the main tasks of the transition and organization of business-process management in agricultural enterprises is to ensure maximum efficiency of the main processes with a focus on achieving strategic goals. The strategic approach allows to design and manage businessprocesses, providing the ability to quickly change the parameters of inputs and outputs to meet the 
needs of target segments, improve the quality of work, speed up the process if necessary, increase productivity, reduce process cost.

The organization of business-processes in agricultural enterprises allows to implement management innovations based on the allocation of individual structural units - business units and specific business-processes. Through coordinated actions of managers at different levels of management, it is possible to carry out step-bystep management changes, which will provide a choice of key activity consistent with the strategic goals of the organization and develop a realistic budget with the distribution of resources between processes.

When transitioning an enterprise management system to a process-oriented management, there may be problems that will prevent the transformation. The main factor that hinders the effective implementation of a process-oriented approach is the lack of interest of management in achieving the set goals and the passivity of employees at all levels.

The process-oriented approach requires the development and implementation of a new system of staff motivation aimed at encouraging initiative from employees, active participation in the process of developing a project model of businessprocesses, building a network of upper and lower levels processes. These features to varying degrees affect the success of the reform, but only a comprehensive approach to their accounting can contribute to achieving the goals in full. Elimination of such shortcomings of management systems as the closure of structural units on top managers, duplication of functions in units and poor coordination between them, can be achieved through improved business-process management.

\section{CONCLUSIONS}

Organizational and technological features of agricultural enterprises are to build an organizational structure of management on a functional basis, and the territorial extent, the specifics of management have caused some difficulties in applying the process approach. A comprehensive approach to implementation will contribute to the achievement of the set goals in full. It includes, in addition to creating a motivational base for planned changes to involve staff in the process of reforming the management system, phased implementation in the following sequence: description, analysis and regulation of businessprocesses; distribution of responsibilities among the participants in the process; allocation and structuring of business-processes; proposals for process optimization; determination of businessprocess management indicators.

To build an effective business-process management system for agricultural enterprises, it is necessary to take into account the interaction of three main elements - key business-processes, enterprise subsystems and types of consumers. When building such a system, it is necessary to consider industry specifics, the presence of a formalized strategy and long-term planning, the size of the enterprise, as well as the impact of macroeconomic factors.

\section{$\Lambda$ ітература:}

1. Аеминг Э. Выход из кризиса. М.: Иза-во "Альпина Бизнес Букс", 2007. 370 с.

2. Портер М. Конкуренция. М.: Издательский дом "Вильямс", 2000. 495 с.

3. Тейлор Ф. Принципы научного менеджмента. Экспертно-аналитический портал. URL: https://gtmarket.ru/laboratory/basis/3631 (дата звернення: 10.11.2021).

4. Recker J., Zelt S., Schmiedel T., Brocke J. Development and validation of an instrument to measure and manage organizational process variety. PLoS ONE. Project: Culture and Business Process Management. 2018. 13 (10). URL: https:// www.researchgate.net/publication/328419897_Development_and_validation_of_an_instrument_to_measure_and_manage_organizational_process_variety (дата звернення: 11.10.2021).

5. Davenport T.N., Short J.E. New Industrial Engineering: Information Technology and Business Process Redesign. Slogan Management Review, 1990. URL: https://sloanreview.mit.edu/article/ the-new-industrial-engineering-informationtechnology-and-business-process-redesign/ (дата звернення: 15.11.2021).

6. Zairi M. Business process management: a boundaryless approach to modern competitiveness. Business Process Management Journal, 1997, vol. 3 (1), pp. 64-80.

7. Репин В.В., Елиферов В.Г. Процессный подход к управлению. Моделирование бизнеспроцессов. М.: РИА "Стандарты и качество", 2004. 398 c.

8. Аогинов К.В. Теория и методы процессного управления промышленным предприятием. СПб.: СПбГИЭУ, 2008. 208 с.

9. Ойхман Е., Попов Э. Реинжиниринг бизнеса: реинжиниринг организаций и информационные технологии. М.: Финансы и статистика, 1997.333 с.

10. Репин B.В. Система стандартизации бизнес-процессов. M.: Business Studio. 2016. 14 с. 
URL: https:// www.FineXpert.ru (дата звернення: 01.11.2021).

11. Репин В.В. Бизнес-процессы компании: построение, анализ, регламентация. М.: РИА "Стандарты и качество", 2007. 240 с.

12. Хаммер М., Чампи Аж. Реинжениринг корпорации. Манифест революции в бизнесе. М.: Манн, Иванов и Фербер, 2006. 332 с.

13. Желєзняк А., Іваницький І. Управління ресурсами аграрних підприємств на основі оптимізації бізнес-процесів. Аграрна економіка. 2016. T. 9, № 1-2. C. 116-122. URL: http:// nbuv.gov.ua/UJRN/ae_2016_9_1-2_20 (дата звернення: 21.10.2021).

14. Яворська Т.І. Методологія вдосконалення управління бізнес процесами у сільськогосподарських підприємствах. Збірник наукових праць Таврійського державного агротехнологічного університету (економічні науки), 2018. Вип. 2 (37). С. 154-161.

15. Надточій I.I. Сутнісно-змістова характеристика бізнес-процесів та особливості управління ними. Вісник ХНАУ. 2020. № 4. Т. 2. C. $3-15$.

16. TeleManagement Forum. Telecom Operations Map. Evaluation Version 2.1. Morristown, NJ: TMForum, 2000. URL: http://or-rsv.narod.ru/ TMForum/TMForum_2.htm/ (дата звернення: 30.10.2021).

\section{References:}

1. Deming, E. (2007), Vyhod iz krizisa [Way out of the crisis], Alpina Business Books, Moscow, Russia.

2. Porter, M. (2000), Konkurencija [Competition], Williams, Moscow, Russia.

3. Taylor, F. (1991), "Principles of Scientific Management", available at: https://gtmarket.ru/laboratory/basis/3631 (Accessed $10 \mathrm{Nov}$ 2021).

4. Recker, J., Zelt, S., Schmiedel, T. and Brocke, J. (2018), "Development and validation of an instrument to measure and manage organizational process variety",PLoS ONE. Project: Culture and Business Process Management, vol. 13(10), available at: https://www.researchgate.net/ publication/328419897_Development_and_validation_of_an_instrument_to_measure_and_manage_organizational_process_variety (Accessed 11 Oct 2021).

5. Davenport, T.N. and Short, J.E. (1990), "New Industrial Engineering: Information Technology and Business Process Redesign",Slogan Management Review, available at: https://sloanreview.mit.edu/article/the-new-industrialengineering-information-technology-and- business-process-redesign/ (Accessed 15 Nov 2021).

6. Zairi, M. (1997), "Business process management: a boundaryless approach to modern competitiveness",Business Process Management Journal, Vol. 3 (1), Pp. 64-80.

7. Repin, V.V. and Eliferov, V.G. (2004), Processnyj podhod k upravleniju. Modelirovanie biznes-processov [Process approach to management. Modeling business processes], Standards and Quality, Moscow, Russia.

8. Loginov, K.V. (2008), Teorija i metody processnogo upravlenija promyshlennym predprijatiem [Theory and methods of process management of an industrial enterprise], Saint Petersburg, Russia.

9. Oikhman, E. and Popov, E. (1997), Reinzhiniring biznesa: reinzhiniring organizacij $\mathrm{i}$ informacionnye tehnologii [Business reengineering: organizations reengineering and information technologies], Finance and Statistics, Moscow, Russia.

10. Repin, V.V. (2016), "Business process standardization system", available at: https: // www.FineXpert.ru (Accessed 01 Nov 2021).

11. Repin, V.V. (2007), Biznes-processy kompanii: postroenie, analiz, reglamentacija [Business processes of the company: construction, analysis, regulation], Standards and Quality, Moscow, Russia.

12. Hammer, M. and Champy, J. (2006), Reinzheniring korporacii. Manifest revoljucii v biznese [Corporation reengineering. Manifesto of the revolution in business], Mann, Ivanov and Ferber, Moscow, Russia.

13. Zheluznyak, A. and Ivanitskiy, I. (2016), "Resource management of agricultural enterprises based on business process optimization",Ahrarna ekonomika, vol. 9, № 1-2, Pp. 116-122, available at: http://nbuv.gov.ua/UJRN/ae_2016_9_1-2_20 (Accessed 21 Oct 2021).

14. Yavorska, T.I. (2018), "Methodology for improving business process management in agricultural enterprises", Zbirnyk naukovykh prats' Tavrijs'koho derzhavnoho ahrotekhnolohichnoho universytetu (ekonomichni nauky), Vol. 2 (37), Pp. 154-161.

15. Nadtochiy, I.I. (2020), "Essential and semantic characteristics of business processes and features of their management",Bulletin of KhNAU, vol. 4, no. 2, Pp. 3-15.

16. TMForum (2000), "TeleManagement Forum. Telecom Operations Map. Evaluation Version 2.1. Morristown", available at: http://orrsv.narod.ru/TMForum/TMForum_2.htm/ (Accessed 30 Oct 2021).

Стаття надійшла до редакиії 22.12.2021 p. 


\title{
А. О. Сітковська,
}

к. е. н., Аоцент, Аоцент кафеАри економіки,

Аніпровський державний аграрно-економічний університет

ORCID ID: 0000-0003-1892-6314

\section{О. А. Савенко,}

к. е. н., доцент кафеАри менеАжменту і права,

Аніпровський Аержавний аграрно-економічний університет, м. Аніпро

ORCID ID: 0000-0002-2362-6263

M. Ю. Капуста,

магістрант, Аніпровський Аержавний аграрно-економічний університет, м. Аніпро

ORCID ID: 0000-0002-1190-5118

DOI: $10.32702 / 2306-6792.2022 .1 .53$

\section{ТЕХНІЧНЕ ЗАБЕЗПЕЧЕННЯ АГРАРНИХ ПІАПРИСМСТВ ЯК ФАКТОР ПІАВИЩЕННЯ КОНКУРЕНТОСПРОМОЖНОСТІ}

\author{
A. Sitkovska, \\ $\mathrm{PhD}$ in Economics, Associate Professor of the Department of Economics, \\ Dnipro State University of Agriculture and Economics, Dnipro \\ O. Savenko, \\ $\mathrm{PhD}$ in Economics, Associate Professor of the Department of Management and Law, \\ Dnipro State University of Agriculture and Economics, Dnipro \\ M. Kapusta, \\ Master's student, Dnipro State University of Agriculture and Economics, Dnipro
}

\section{TECHNICAL SUPPORT OF AGRICULTURAL ENTERPRISES AS A FACTOR OF INCREASING COMPETITIVENESS}

У статті розглянуто сучасний стан технічного забезпечення аграрних підприємств та перспективи оновлення техніки в аграрному секторі, його пріоритетність у формуванні ресурсного потенціалу. Виокремлено проблеми, які зумовлені рівнем технічного забезпечення підприємств. Визначено чинники, що впливають на конкурентні позиції підприємств. Розглянуто ефективність діяльності суб'єктів підприємництва різних розмірів (великих, середніх, малих) в аграрному секторі та його вплив на можливості формування матеріально-технічної бази, що використовуються у виробничих процесах. Визначено причини низької інвестиційної привабливості сільського господарства як галузі національної економіки країни. Розглянуто внутрішні і зовнішні чинники, які впливають на покращання технічного забезпечення аграрних підприємств. Встановлено, що комплексне використання чинників сприятиме оновленню машинно-тракторного парку та зростання ефективності його використання.

The article considers the current state of technical support of agricultural enterprises and prospects for updating equipment in the agricultural sector, its priority in the formation of resource potential.

Solving the problem of improving production efficiency and competitive position of the enterprise increasingly depends on the rational use, further growth and improvement of fixed assets, especially on its active part, the effectiveness of which depends on their timely quality update. The main means of production and, in particular, technical means of production used by agricultural enterprises, currently differ significantly, as they are formed depending on financial capabilities, size of enterprises, and to some extent do not meet the requirements of agricultural technology. It is established that the low level of technical support leads to the violation of technologies of agricultural production, increase its losses, cause technological backwardness. Low quality of equipment does not allow to introduce innovative technologies and move to a higher level of development of the domestic agricultural sector. Socio-economic aspects of rural life and work have intensified. The update of equipment on the main elements is analyzed. It is determined that in the current market conditions, due to the difficult financial situation of a large number of agricultural producers, their ability to allocate their own funds to form an investment fund is limited. It is noted that the main reasons why the logistics 
of enterprises of various forms of management is at an inadequate level include lack of funds for small and medium enterprises, imperfect credit and depreciation policy, insufficient government support. Large enterprises have greater financial opportunities to upgrade the material and technical base. It is noted that the differences in the activities of agricultural enterprises are due to the specifics of the industry and a number of features that affect investment and indicate a low level of investment attractiveness of the industry. It is proposed to use both internal and external factors in order to update and improve the technical support of the industry. Their application will contribute to the renewal of the machine-tractor fleet and increase the efficiency of its use. It is established that the state and prospects of development of business entities largely depend on the development of material and technical base used in the production processes of agricultural formations. It has its own specifics related to the peculiarities of the functioning of the industry and its renewal and continuous improvement is one of the main vectors of strategic development of the enterprise.

Ключові слова: основні засоби, сільськогосподарська техніка, аграрне підприєлтво, конкурентоспроможність, прибуток.

Key words: capital, agricultural machinery, agricultural enterprise, competitiveness, income.

\section{ПОСТАНОВКА ПРОБЛЕМИ}

В умовах ринкової економіки ведеться постійна боротьба суб'єктів господарювання за лідерство на ринках, використання найбільш вигідних умов виробництва та реалізації своїх товарів. Успіх досягається тими організаціями, продукція яких має більшу конкурентоспроможність, містить певний набір конкурентних переваг у порівнянні з іншою продукцією, представленою на ринку. Аосягти зростання виробництва конкурентоспроможної сільськогосподарської продукції, підвищити продуктивності праці можливо за рахунок забезпеченості аграрних підприємств основними засобами, відповідного якісного складу та їх раціонального співвідношення. 3 урахуванням цих обставин актуальним стає вивчення особливостей технічного забезпеченні виробництва в аграрних підприємствах та впливу його на ефективність функціонування.

\section{АНАЛІЗ ОСТАННІХ ДОСЛІДЖЕНЬ І ПУБЛІКАЦІЙ}

Серед опублікованих останніми роками праць, в яких розглянуто проблеми формування та використання матеріально-технічної бази підприємств аграрного сектору, вивченням піi сучасного стану і процесів розвитку, матеріально-технічного забезпечення сільського господарства варто виділити вчених: В.Г. Андрійчук, O.В. Захарчук, В.В. Іванишин, К.М. Мельник, П.Т. Саблук, О.В. Ульянченко та ін.

Водночас динамічні зміни в середовищі функціонування аграрних підприємств, значна варіація основних характеристик їхніх розмірів вимагають продовження дослідження ефективності діяльності цих підприємств залежно від рівня їх технічного забезпечення.

\section{МЕТА ДОСЛІДЖЕННЯ}

Метою дослідження є оцінка рівня технічного забезпечення виробництва та його вплив на ефективність та конкурентоспроможність аграрних підприємств.

\section{ВИКЛАД ОСНОВНОГО МАТЕРІАЛУ ДОСЛІДЖЕННЯ}

У практичній складовій бізнесу критерієм ефективного функціонування суб'єкта підприємництва виступають поточні доходи, які відображають фактичну ефективність і майбутні очікувані доходи від продажу фірми чи її частини. Відповідно, чим сприятливіші перспективи, тим вище обсяг наявних ресурсів і тим вища його конкурентоспроможність бізнесу. Особливістю конкуренції є те, що розорення бізнесу, як правило, зумовлено розвитком конкурентів, тобто на ринку одна маса товарів заміщується іншими, від чого виграє споживач. Аграрний сектор у зв'язку з особливостями, а саме сезонність виробництва, обмеженість земельних ресурсів, використання живих організмів тощо, обмежує можливості ринкових сил реалізувати механізм стійкого і динамічного розвитку в повній мірі [1].

Одним 3 найважливіших елементів ресурсного потенціалу, який є важливим фактором формування конкурентоспроможності підприємства, виступає матеріально-технічна база, яка повинна розвиватися на основі впровадження нових технологій, комплексної механізації, автоматизації виробничих процесів в усіх його галузях, постійного поліпшення використання природних ресурсів. Це забезпечить формування ресурсного потенціалу, здатного реалізувати стратегічні завдання, які стоять перед сільським господарством країни [2]. 
Таблиця 1. Наявність та забезпечення аграрних підприємств сільськогосподарською технікою

\begin{tabular}{|l|l|l|l|l|l|l|}
\hline \multicolumn{1}{|c|}{ Сільськогосподарська техніка } & 2010 & 2017 & 2018 & 2019 & 2020 & $\begin{array}{c}2020 \text { у \% } \\
\text { до 2010 }\end{array}$ \\
\hline Трактори - всього: тис. шт & 151,3 & 132,7 & 129,3 & 128,7 & 130,5 & 86,3 \\
\hline - на 10000 га ріллі, од. & 47 & 41 & 40 & 39 & 40 & 85,1 \\
\hline Зернозбиральні комбайни, тис. шт. & 32,8 & 27,4 & 26,8 & 26,3 & 26,5 & 80,8 \\
\hline - на 10000 га посівної площі зернових, од. & 36 & 38 & 38 & 36 & 37 & 102,8 \\
\hline кукурудзозбиральні комбайни, тис. шт. & 2,5 & 1,5 & 1,5 & 1,5 & 1,5 & 60,0 \\
\hline - на 10000 га посівної площі кукурудзи, од. & 12 & 5 & 4 & 4 & 4 & 33,3 \\
\hline Картоплезбиральні комбайни, тис. од. & 1,7 & 1,2 & 1,1 & 0,9 & 1,0 & 58,8 \\
\hline - на 10000 га посівної площі картоплі,од. & 590 & 553 & 612 & 585 & 592 & 100,3 \\
\hline Бурякозбиральні комбайни, тис. од. & 4,2 & 2,3 & 2,0 & 1,6 & 1,6 & 38,1 \\
\hline - на 10000 га посівної площі буряків, од. & 92 & 84 & 68 & 63 & 77 & 83,7 \\
\hline
\end{tabular}

Ажерело: [6].

Таким чином вирішення задачі підвищення ефективності виробництва та конкурентоспроможності підприємства все більше залежить від раціонального використання, подальшого росту й удосконалювання основних засобів, особливо від активної їі частини, ефективність використання яких залежить від своєчасного їнього якісного оновлення. Основні виробничі засоби i, зокрема технічні засоби виробництва, які використовують аграрні підприємства, на даний час істотно різняться, оскільки сформовані в залежності від фінансових можливостей, розміру підприємств, і в певній мірі не відповідають вимогам агротехнології. Частина наявної сільськогосподарської техніки відзначається великою енергомісткістю, технологічною недосконалістю, низькою ефективністю і дуже високою ціною. Через це навантаження на техніку надзвичайно високе (табл. 1). У 2020 році порівняно з 2010 роком оснащеність окремими видами техніки знизилася на $15-64 \%$, сягає половини технологічної потреби і щорічно знижується. Водночас з 2020 р. показники забезпеченості починають зростати. Порівня-

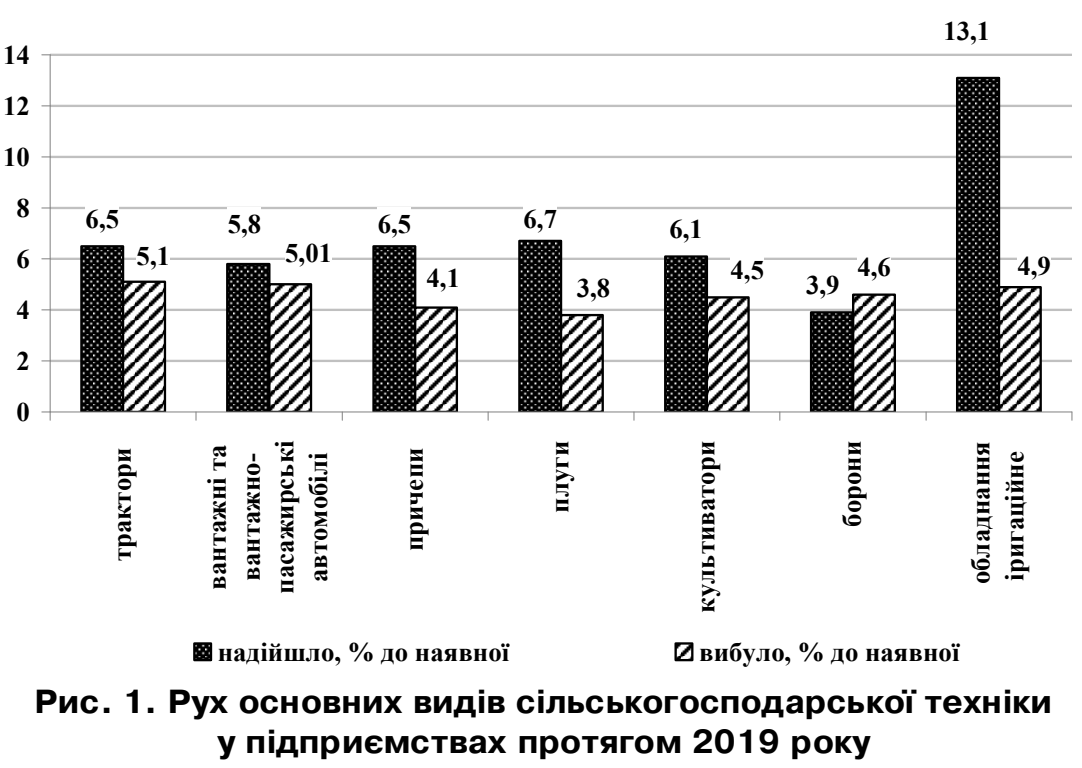

но 32010 роком наявність тракторів в аграрних підприємствах в 2020 р. скоротилася на 13,7\%, зернозбиральних комбайнів - 19,2\%, кукурудзозбиральних комбайнів - 40,0\%, бурякозбиральних машин -61,9\%. Близько $85 \%$ техніки в аграрних підприємствах експлуатується за межами амортизаційних строків.

Вітчизняна техніка за якістю відстає від світових аналогів, а за продуктивністю значно їм поступається. Негаразди технічного забезпечення призводять до порушення технологій виробництва аграрної продукції, збільшують їі втрати, зумовлюють технологічну відсталість. Низька якість техніки не дає можливості впроваджувати інноваційні технології та перейти до вищого рівня розвитку вітчизняного аграрного сектору. Загострилися соціально-економічні аспекти сільського життя, праці. Однак спостерігаються певні позитивні зрушення в напрямку оновлення техніки в аграрному секторі (рис. 1). Як бачимо в продовж 2019 року оновлення техніки по всім елементам було швидше, ніж її вибуття. Поступове нарощування оновленої матеріально-технічної бази та раціональне використання її разом з іншими ресурсами галузі сприятиме посиленню позицій аграрних товаровиробників, максимізації одержання доходів та впливатиме на конкурентоспроможність підприємств галузі як на національному ринку так і з іноземними виробниками.

У нинішніх ринкових умовах, зважаючи на складну фінансову ситуацію у великої кількості сільськогосподарських товаровиробників, їх можливості щодо виділення власних коштів для формування інвестиційного фонду обмежені. Тому першочерговим завданням у форму- 


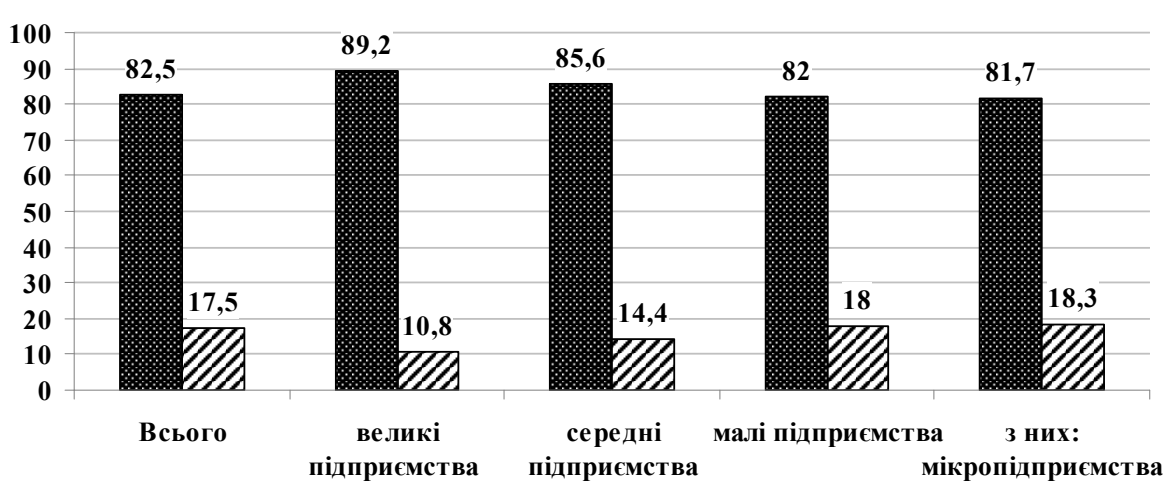

푤пємства, які одержали прибуток (\% до загальної кількості підприємств)

$\square$ підприсмства, які одержали збиток (\% до загальної кількості підприсмств)

Рис. 2. Основні показники діяльності підприємств у залежності від розміру в середньому за період 2010-2018 рр.

ванні ефективного сільськогосподарського виробництва повинно бути створення для аграрних підприємств сприятливих умов для прибуткового господарювання [5].

Конкурентна боротьба на внутрішньому ринку є постійною і доволі жорсткою, що пов'язано в цілому зі станом конкурентного середовища, яке характеризується високими рівнем адміністративних бар'єрів, митних тарифів, непрозорістю обмінних процесів та інших факторів, які не підпадають під категорію законності. Перепоною виступає й невідповідність темпів і якості розвитку інфраструктури потребам бізнесу. Всі ці чинники, а також природно-кліматичні, фінансові, демографічні здійснюють вплив на основні показники діяльності аграрних підприємств.

Вплив конкурентного середовища висвітлив тенденцію щодо зниження кількості аграрних підприємств за останнє десятиліття на 15,9\% (2010-2020 рр.). За цей же період зниження чисельності фермерських господарств було суттєвішим - на 23,7\%. Однак не можна списувати все лише на негативні тенденції, у цих процесах $€$ циклічні закономірності. Вони пов'язані 3 еволюційним процесом розвитку малих i дрібних підприємств, які створюються, ліквідуються у процесі конкурентного середовища. Крім того, в країні відбуваються закономірні процеси об'єднання підприємств (наприклад, створення кооперативів), укрупнення фермерських господарств, створення агрохолдингів. Тому розглядати слід не лише кількісні зміни, а й якісні, тобто з обов'язковим урахуванням їх фінансових результатів (рис. 2).

За останні майже десять років простежується чітка тенденція щодо зростання частки прибуткових підприємств у категорії великі. Їх частка є найбільшою - 89,2\%. Крім того, в 2016 i
2018 рр. частка підприємств, які отримали прибуток складала $100 \%$, що спостерігалося лише для цієї групи підприємств. Тому до основних причин, через які матеріально-технічне забезпечення підприємств різних форм господарювання знаходиться на неналежному рівні можна віднести недостатність коштів у підприємств малих та середніх форм господарювання, недосконалість кредитної та амортизаційної політики, недостатня державна підтримка [3]. Тоді як покращення фінансових показників великих підприємств в аграрному секторі відображає позитивні тенденції, що намітилися у структурі парку сільськогосподарської техніки країни, а саме те, що зниження кількості техніки являе собою природну реакцію сільгоспвиробників на підвищення іï продуктивності. Це підтверджується динамікою посівних площ та валового збору сільськогосподарських культур. Так, зниження забезпеченості сільськогосподарського виробництва технікою не зменшує обсягів виробництва сільськогосподарської продукції [3].

Аіяльність аграрних підприємств має відмінності, що зумовлені специфікою галузі і рядом особливостей, так одні види підприємництва формуються за рахунок залучення масштабних інвестицій і високотехнологічної виробничої бази, інші засновані на індивідуальній діяльності, примітивній в технологічному відношенні. На жаль, інвестиційна привабливість сільського господарства України є низькою, що безпосередньо вплинуло на обсяги інвестування галузі. За останнє десятиліття обсяги інвестицій в основний капітал із розрахунку на 1000 грн основних засобів у сільське господарство зросли лише на $10,0 \%$, тоді як в цілому по країні їх зростання склало 2,5 рази. Науково-технічний прогрес зумовив, у більшій мірі, найбільш привабливі сфери для капіталов- 
кладень, до числа яких сільське господарство не увійшло [4].

Вирішувати ситуацію з оновленням, покращанням технічного забезпечення галузі слід комплексно використовуючи як внутрішні чинники (створення машино-технічних об'єднань, 3 оптимально укомплектованим складом виробничих засобів, наприклад для малих і середніх підприємств; великим - формувати машинно-тракторний парк, виходячи 3 наявних можливостей), так і зовнішні (наприклад, державна програма часткової компенсації вартості техніки та обладнання вітчизняного виробництва). Їх застосування сприятиме оновленню машино-тракторного парку та зростання ефективності його використання.

\section{ВИСНОВКИ}

Проблема забезпечення аграрних підприємств технічними засобами, їх формування на основі якості та високої продуктивності є однією з нагальних для галузі. Ситуація, яка склалася в аграрному секторі країни потребує розгляду ефективних заходів, спрямованих на посилення матеріально-технічного забезпечення галузі, пошуку джерел фінансування, впровадження в практику інноваційних моделей розвитку. Технічний рівень сьогодні повинен забезпечувати не лише високу готовність машино-тракторного парку до виконання агротехнологічних операцій, але й значно подовжити життєвий цикл техніки. Без ретельного обгрунтування і вирішення поставлених завдань, неможливо найближчим часом зміцнити матеріально-технічну базу сільського господарства.

Вирішення зазначених проблем дозволить підвищити результативність діяльності, і в кінцевому підсумку покращити конкурентний стан аграрного підприємства на відповідному сегменті ринку.

$\Lambda$ ітература:

1. Вініченко I.І., Сорока Ю.О. Ефективність використання ресурсного потенціалу сільськогосподарських підприємств. Інвестиції: практика та досвід. 2015. № 22. С. 34-37.

2. Руснак П.П., Жебка В.В., Рудий М.М., Чалий А.А. Економіка сільського господарства. Київ: Урожай, 1998. 320 с.

3. Захарчук O.В. Технічне забезпечення сільськогосподарських підприємств в Україні. Економіка АПК. 2019. № 2. С. 48.

4. Кустріч $\Lambda . О$. Особливості залучення інвестицій у сільське господарство: сучасний стан і тенденції розвитку. Інвестиції: практика та досвід. 2017. № 24. С. 37-42.
5. Олійник Т. Інтенсифікація відтворення основних засобів аграрного виробництва. Вісник Бердянського університету менеджменту і бізнесу. 2010. № 2 (10). С. 61-65.

6. Сільське господарство України за 2020 рік: статистичний збірник. К.: Аержаналітінформ, 2021. 231 с.

\section{References:}

1. Vinichenko, I.I. and Soroka, Yu.O. (2015), "Efficiency of using the resource potential of agricultural enterprises", Investytsii: praktyka ta dosvid, vol. 22, pp. 33-37.

2. Rusnak, P.P. Zhebka, V.V. Rudy, M.M. and Chaly, A.A. (1998), Ekonomika sil's'koho hospodarstva [Agricultural economics], Urozhaj, Kyiv, Ukraine.

3. Zakharchuk, O.V. (2019), "Technical support of agricultural enterprises in Ukraine", Ekonomika APK, vol. 7, pp. 42-44.

4. Kustrich, L.O. (2017), "Features of attracting investment in agriculture: current status and development trends", Investytsii: praktyka ta dosvid, vol. 24, pp. 37-42.

5. Oliynyk, T. (2010), "Intensification of reproduction of fixed assets of agricultural production", Visnyk Berdyanskogo universitety menedzhmenty i biznese, vol. 2 (10), pp. 61-65.

6. Derzhanalitinform (2021), Sil's'ke hospodarstvo Ukrainy za 2020 rik: statystychnyj zbirnyk [Agriculture of Ukraine for 2020: statistical collection], Derzhanalitinform, Kyiv, Ukraine.

Стаття надійшла до редакчї 20.12.2021 p.

\section{www. economy.nayka.com.ua}

Електронне фахове видання

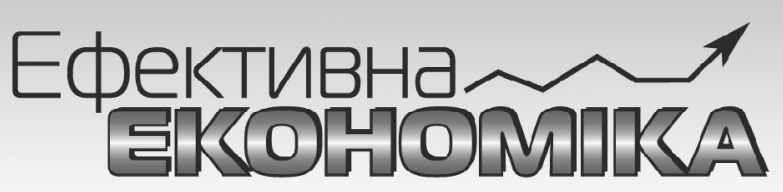

\section{Виходить 12 разів на рік}

Хурнал включено до переліку наукових фахових видань України з ЕКОНОМІЧНИХ НАУК (Категорія «Б»)

Спеціальності - 051, 071, 072, 073, 075, 076, 292

e-mail: economy_2008@ukr.net тел.: (044) 223-26-28

(044) $458-10-73$ 
УAK 504.005:334:631.11

\title{
О. В. Аопушинська,
}

Аоктор філософії з менеАжменту, доцент кафеАри менеджменту імені I. А. Маркіної,

Полтавський державний аграрний університет, м. Полтава

ORCID ID: 0000-0001-5201-9027

А. О. Микитенко,

зАобувач вищої освіти спеціальності "Менеджмент",

Полтавський Аержавний аграрний університет, м. Полтава

ORCID ID: 0000-0002-0429-5139

К. О. Смірнова,

здобувач вищої освіти спеціальності "Менеджмент",

Полтавський державний аграрний університет, м. Полтава

ORCID ID: 0000-0002-2150-6647

\section{ЕКОЛОГІЧНА СКЛААОВА МЕНЕАЖМЕНТУ РЕСУРСОЗБЕРЕЖЕННЯ АГРАРНИХ ПІАПРИЄМСТВ У КОНТЕКСТІ ЗАБЕЗПЕЧЕННЯ СТІЙКОГО РОЗВИТКУ}

\author{
O. Lopushynska, \\ $\mathrm{PhD}$ in Management, Associate Professor of Management named after I.A. Markina, \\ Poltava State Agrarian University, Poltava \\ A. Mykytenko, \\ Applicant for higher education specialty Management, Poltava State Agrarian University, Poltava \\ K. Smyrnova, \\ Applicant for higher education specialty Management, Poltava State Agrarian University, Poltava
}

\section{ECOLOGICAL COMPONENT OF RESOURCE SAVING MANAGEMENT OF AGRICULTURAL ENTERPRISES IN THE CONTEXT OF ENSURING SUSTAINABLE DEVELOPMENT}

У статті досліджено та обгрунтувано теоретико-методологічні основи екологічної складової менеджменту ресурсозбереження аграрних підприємств у контексті забезпечення стійкого розвитку. Окреслено основні напрями негативного впливу діяльності аграрних підприємств на екологію, серед яких автори виділили наступні: виснаження землі та втрата родючості грунту, ерозія грунту, стік нітратів, ущільнення грунту, біоцидні спреї, втрата біорізноманіття, викиди забруднюючих речовин в атмосферне повітря, забруднення підземних вод. Визначено показники, що характеризують екологічну ефективність менеджменту ресурсозбереження аграрного підприємства, сереА яких: коефіцієнт природоємності; коефіцієнт природної ресурсовідАачі; коефіцієнт екологоємності; коефіцієнт ресурсоємності процесу; коефіцієнт екологічності об'єкту; коефіцієнт відходоємкості; коефіцієнт екологічності виробництва.

Автори зазначають, що культура ресурсозбереження повинна стати обов'язковим елементом загальної культури поведінки особистості і культури професійної діяльності працівників аграрних підприємств. Формування ефективної системи менеджменту ресурсозбереження аграрних підприємств, на думку авторів, повинно включати низку складових, а саме: систему управління, організаційну підтримку, фінансування, мотиваційні програми. В статті визначено основні етапи формування та корегування організаційної культури на аграрному підприємстві, яка містить складову ресурсозбереження. 
For most modern agricultural enterprises, it is important to identify areas of economic and management activities that will help use natural resources efficiently, because a smart approach will help preserve and restore our habitat, protect and improve soil and water quality.

The aim of the article is to study and substantiate the theoretical and methodological foundations of the environmental component of management of resource conservation of agricultural enterprises in the context of sustainable development, as well as to determine the impact of agriculture on the environment.

The article outlines the main areas of negative impact of agricultural enterprises on the environment, among which the authors identified the following: soil depletion and loss of soil fertility, soil erosion, nitrate runoff, soil compaction, biocidal sprays, biodiversity loss, emissions of pollutants into the air, pollution. vod.

According to the authors, the management of resource conservation of agricultural enterprises should be a comprehensive process related not only to improving economic and social efficiency, but also contain an environmental component. The article identifies indicators that characterize the environmental efficiency of resource conservation management of agricultural enterprises, including: coefficient of nature; natural resource efficiency; environmental intensity factor; coefficient of resource intensity of the process; coefficient of environmental friendliness of the object; waste ratio; environmental friendliness of production.

In addition, the authors note that the culture of resource conservation should become a mandatory element of the general culture of personal behavior and the culture of professional activity of agricultural workers. The formation of an effective management system for resource conservation of agricultural enterprises, according to the authors, should include a number of components, namely: management system, organizational support, financing, incentive programs. The article identifies the main stages of formation and adjustment of organizational culture in the agricultural enterprise, which contains a component of resource conservation.

Ключові слова: аграрні підприємства, екологія, ефективність, менеджмент, ресурсозбереження, стійкий розвиток.

Key words: agricultural enterprises, ecology, efficiency, management, resource conservation, sustainable development.

\section{ПОСТАНОВКА ПРОБЛЕМИ У ЗАГАЛЬНОМУ ВИГЛЯДІ ТА ІІЇ ЗВ'ЯЗОК ІЗ ВАЖЛИВИМИ НАУКОВИМИ ЧИ ПРАКТИЧНИМИ ЗАВДАННЯМИ}

Сільське господарство є однією з найбільших галузей економіки в світі. Сільськогосподарські угіддя та пасовища займають близько 50 \% придатної для життя землі та забезпечують середовищем проживання та їжею велику кількість людей та видів тварин. Сьогодні для більшості сучасних аграрних підприємств $€$ актуальним визначення напрямів господарської та управлінської діяльності, які допоможуть ефективно використовувати природні ресурси, адже розумний підхід допоможе зберегти та відновити наше середовище існування, захистити та покращити якість грунту та води. Крім того, аграрна сфера є базисом формування продовольчої безпеки держави та має вагомий вплив на стан національної економіки країни. Окрім забезпечення підприємств і населення сировиною та продуктами харчування, аграрна сфера надає можливості для працевлаштування значній частині населення. Так, за даними 2020 року у сільському господарстві України зайнято близько 18 \% працездатного населення.

На міжнародній арені Україна позиціонує себе як аграрна держава. Протягом останнього десятиліття спостерігається значне збільшення виробництва сільськогосподарської продукції в Україні. При цьому далеко не всі аграрні підприємства розуміють значення використання ресурсозберігаючих технологій та застосовують у своїй діяльності принципи стійкого розвитку. Наш час характеризується активізацією антропогенних впливів на навколишнє середовище, оскільки широке застосування новітніх технологій в діяльності аграрних підприємств прискорює необхідність забезпечення потреб населення в різних видах ресурсів та актуалізує питання їх збереження. 


\section{АНАЛІЗ ОСТАННІХ ДОСЛІДЖЕНЬ І ПУБЛІКАЦІЙ, В ЯКИХ ЗАПОЧАТКОВАНО РОЗВ'ЯЗАННЯ ДАНОЇ ПРОБЛЕМИ І НА ЯКІ СПИРАЄТЬСЯ АВТОР, ВИДІЛЕННЯ НЕ ВИРІШЕНИХ РАНІШЕ ЧАСТИН ЗАГАЛЬНОЇ ПРОБЛЕМИ, КОТРИМ ПРИСВЯЧУЄТЬСЯ ОЗНАЧЕНА СТАТТЯ}

Актуальні проблеми розвитку аграрної сфери економіки та застосування ресурсозберігаючих технологій та методик відображені в наукових працях учених світової та вітчизняної наукової спільноти, зокрема А. Беляєвої, I. Маркіної, Н. Вдовенко, М. Зось-Кіора, І. Гнатенко, А. Аячкова, Є. Овчаренка, $\Lambda$. Мельника, Ю. Азядикевича, I. Сотник, О. Чигирин та інших. Проте більшість аграрних підприємств України мають значні недоліки, які стосуються формування ефективної системи менеджменту ресурсозбереження в контексті екологічної складової, що зумовлює необхідність пошуку напрямів удосконалення їх діяльності.

\section{META CTATTI}

Метою статті $€$ дослідження та обгрунтування теоретико-методологічних основ екологічної складової менеджменту ресурсозбереження аграрних підприємств у контексті забезпечення стійкого розвитку, а також визначення впливу діяльності сфери сільського господарства на навколишнє середовище.

\section{ВИКЛАД ОСНОВНОГО МАТЕРІАЛУ ДОСЛІДЖЕННЯ 3 ПОВНИМ ОБГРУНТУВАННЯМ ОТРИМАНИХ НАУКОВИХ РЕЗУЛЬТАТІВ}

Рослинництво та тваринництво здійснюють великий вплив на довкілля. Вони є основним джерелом забруднення води нітратами, фосфатами та пестицидами. Аграрна сфера також $є$ основним антропогенним джерелом парникових газів метану та закису азоту, а також сприяє у масовому масштабі іншим видам забруднення повітря та води [1]. Сільське господарство також здійснює негативний вплив на довкілля через деградацію земель, засолення, надмірне вилучення води та зменшення генетичного різноманіття сільськогосподарських культур і тварин [2].

Більшість сучасних фермерських господарства відмовились від кваліфікованого землеробства, яке колись було провідним принципом обробки землі. Сьогодні акцент робиться виключно на продуктивності - це великі витрати на високу віддачу. Власники аграрного бізнесу не враховують, що відбувається із землею, 3 урожаєм та людьми, які споживають аграрну продукцію [1].

Понад дві третини води, яку використовує людина, припадає на сільське господарство. Забруднення підземних вод сільськогосподарськими хімікатами та відходами є серйозною проблемою майже у всіх розвинених країнах i, дедалі частіше, у багатьох країнах, що розвиваються. Споживання води в свою чергу має тенденцію росту.

Забруднення добривами відбувається, коли ї вносять більше, ніж сільськогосподарські культури цього потребують, або коли вони змиваються чи здуваються з поверхні грунту. Надлишок азоту і фосфатів може вимиватися в грунтові води або стікати у водні шляхи. Це перевантаження поживними речовинами викликає евтрофікацію озер, водойм і ставків, що призводить до збільшення кількості водоростей, які пригнічують інші водні рослини і тварин [3].

В Україні в діяльності аграрних підприємств широко застосовуються інсектициди, гербіциди та фунгіциди, що призводить до забруднення прісної води канцерогенами та іншими отрутами, які здійснюють негативний вплив на навколишнє середовище. Пестициди також зменшують біорізноманіття, знищуючи бур'яни та комах, а отже, і харчові види птахів та інших тварин [4; 5]. Використання пестицидів суттєво зросло за останні 35 років. У деяких регіонах останнім часом темпи зростання становили від 4 \% до 5, 4 \%.

Сільське господарство також є джерелом забруднення повітря. Аомінуючим антропогенним джерелом аміаку є тваринництво, яке становить близько $40 \%$ світових викидів, мінеральні добрива - $16 \%$, а спалювання біомаси та рослинні рештки - близько $18 \%$ [2].

Спалювання біомаси рослин є ще одним основним джерелом забруднювачів повітря, включаючи вуглекислий газ, закис азоту та частки диму. Підраховано, що близько 90 \% спалювання біомаси виникли з участю людини, головним чином через навмисне спалювання лісової рослинності у зв'язку з вирубкою лісів, а також пасовищ і рослинних решток [3]. Прогнози свідчать про те, що до 2030 року викиди аміаку та метану з сектору тваринництва країн, що розвиваються, можуть бути щонайменше на $60 \%$ вищими, ніж зараз.

Аміак підкислює навіть більше, ніж діоксид сірки та оксиди азоту. Це одна з основних причин кислотних дощів, які пошкоджують дерева, підкислюють грунти і завдають шкоди біорізноманіттю. Оскільки інші гази, що підкислю- 


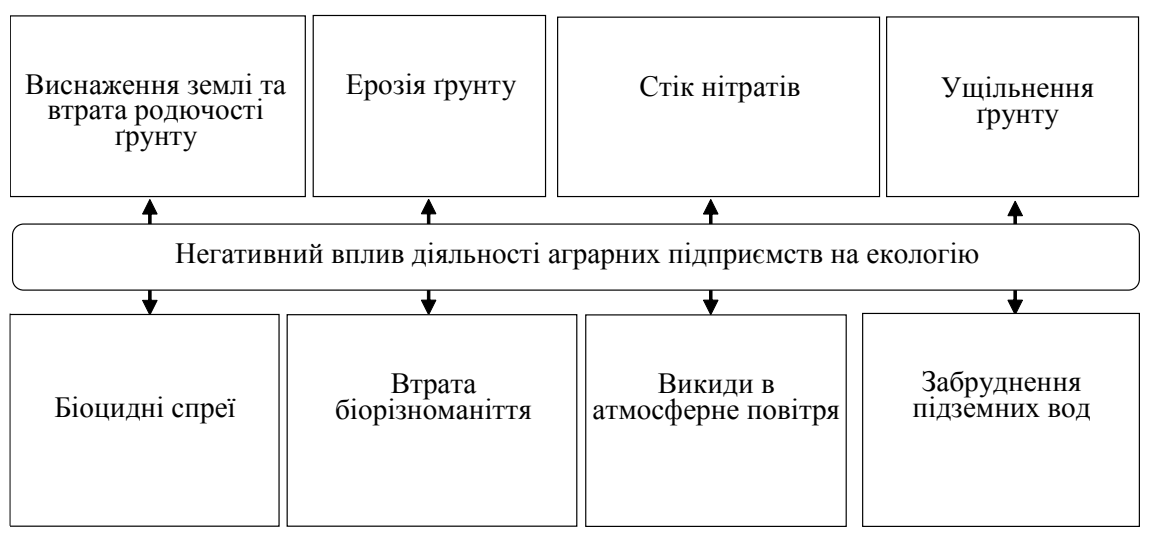

Рис. 1. Негативний вплив діяльності аграрних підприємств

Ажерело: [2;5].

ють, як-от: діоксид сірки, стають під жорсткішим контролем, аміак з часом може стати основною причиною підкислення. Викиди аміаку від сільського господарства за прогнозами екологів і економістів продовжуватимуть зростати як у розвинених країнах, так і в країнах, що розвиваються [5;6].

Сільське, лісове та рибне господарство негативним чином впливає на біорізноманіття суші та моря. Видове багатство тісно пов'язане з ареалом дикого середовища проживання. Оскільки площа зменшується, зменшується й кількість видів. Вирубка лісів, консолідація полів із супутнім скороченням окраїн і живоплотів, а також осушення водно-болотних угідь для ведення сільського господар- ства зменшують загальну площу, доступну для дикої природи [4; 7]. Пестициди та гербіциди знищують багатьох комах і небажаних рослин, тим самим зменшуючи запаси їжі для деяких тварин. Тиск на біорізноманіття протягом наступних трьох десятиліть буде наслідком суперечливих тенденцій. Екстенсивні методи, як правило, поступаються місцем інтенсифікації, яка, у свою чергу, може поступитися місцем органічному сільському господарству [3].

Основні напрями негативного впливу діяльності аграрних підприємств на екологію окреслено на рисунку 1.

Якщо використовувати більш стійкі методи виробництва, негативний вплив сільського гос-

\section{Таблиця 1. Основні показники екологічної ефективності аграрного підприємства}

\begin{tabular}{|c|c|c|c|}
\hline \begin{tabular}{|c|} 
№ \\
П/ா
\end{tabular} & $\begin{array}{c}\text { Показники } \\
\text { ефективності } \\
\text { ресурсозберігаючого } \\
\text { розвитку }\end{array}$ & Характеристика & $\begin{array}{c}\text { Можливе } \\
\text { порогове } \\
\text { значення / } \\
\text { нормативне } \\
\text { значення }\end{array}$ \\
\hline 1 & $\begin{array}{l}\text { Коефіцієнт } \\
\text { природоємності }\end{array}$ & $\begin{array}{l}\text { Співвідношення витрат використаних } \\
\text { природних ресурсів до чистого доходу від } \\
\text { реалізації }\end{array}$ & Зменшення \\
\hline 2 & $\begin{array}{l}\text { Коефіцієнт природної } \\
\text { ресурсовіддачі }\end{array}$ & $\begin{array}{l}\text { Співвідношення чистого доходу від } \\
\text { реалізації до витрат використаних } \\
\text { природних ресурсів }\end{array}$ & Збільшення \\
\hline 3 & $\begin{array}{l}\text { Коефіцієнт } \\
\text { екологоємності }\end{array}$ & $\begin{array}{l}\text { Характеризує рівень шкідливих дій на } \\
\text { довкілля з розрахунку на одиницю } \\
\text { корисної продукції або послуги, що } \\
\text { отримуються за допомогою цього процесу }\end{array}$ & Зменшення \\
\hline 4 & \begin{tabular}{|l|} 
Коефіцієнт \\
ресурсоємності процесу
\end{tabular} & $\begin{array}{l}\text { Характеризує витрати енергії, води, } \\
\text { повітря, земельних і інших природних } \\
\text { ресурсів з розрахунку на одиницю } \\
\text { корисної продукції або послуги }\end{array}$ & Зменшення \\
\hline 5 & $\begin{array}{l}\begin{array}{l}\text { Коефіцієнт } \\
\text { екологічності об'єкту }\end{array} \\
\end{array}$ & $\begin{array}{l}\text { Співвідношення чисто корисного ефекту } \\
\text { до витрачених природних ресурсів }\end{array}$ & $\geq 1$ \\
\hline 6 & $\begin{array}{l}\text { Коефіцієнт } \\
\text { відходоємкості }\end{array}$ & $\begin{array}{l}\text { Співвідношення маси відходів, приведеної } \\
\text { до єдиного об'єму, з урахуванням } \\
\text { відмінностей міри їх шкідливості } \\
\text { (небезпеки) з розрахунку на одиницю } \\
\text { продукції }\end{array}$ & Зменшення \\
\hline 7 & \begin{tabular}{|l} 
Коефіцієнт \\
екологічності \\
виробництва
\end{tabular} & $\begin{array}{l}\text { Різниця між вартістю сировини, яку } \\
\text { приймають } 31, \text { і вартістю утворених } \\
\text { відходів }\end{array}$ & $\rightarrow 1$ \\
\hline
\end{tabular}




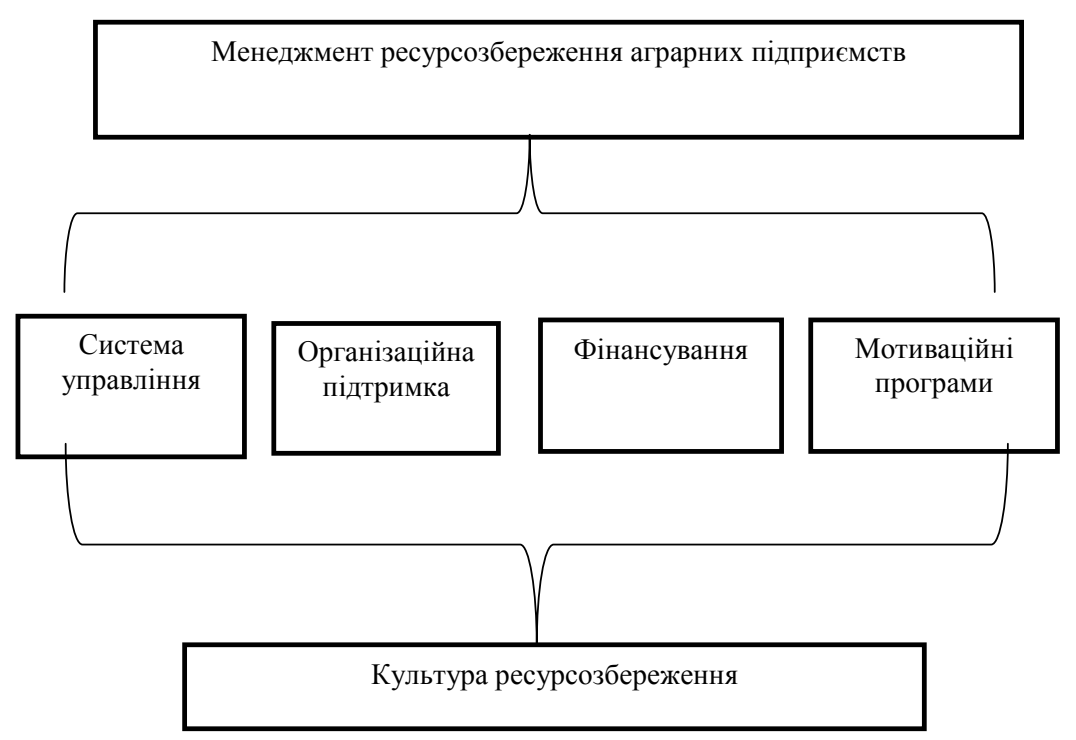

Рис. 2. Основні складові ефективного менеджменту ресурсозбереження аграрних підприємств

подарства на навколишнє середовище можна послабити. Серед напрямів зменшення негативного впливу на екологію від діяльності аграрних підприємств можна виділити такі: підвищення ефективності використання добрив; розповсюдження сортів рису, що виділяють менше метану; удосконалення управління відходами тваринництва; відновлення деградованих земель; удосконалення управління рослинними залишками; розширення агролісомеліорації та лісовідновлення; підтримка мобільності худоби на скотарських територіях, схильних до посухи тощо.

Перехід аграрної сфери на новий рівень розвитку можливий лише за умови докорінної зміни характеру розвитку продуктивних сил, відмови від екстенсивного типу економічного зростання, переходу до інтенсивних факторів. Аля цього необхідно розв'язати проблеми раціонального, економного використання ресурсів. Тому перед урядом нашої держави і перед керівниками аграрних підприємств постає завдання забезпечення ефективного ресурсозбереження [6;7;8].

Менеджмент ресурсозбереження аграрних підприємств повинен представляти собою комплексний процес, пов'язаний не тільки 3 покращенням показників економічної та соціальної ефективності, а також містити екологічну складову [9]. Ао групи показників, що характеризують екологічну ефективність менеджменту ресурсозбереження аграрного підприємства можна віднести такі коефіцієнти (табл. 1).

Інтегральний показник менеджменту екологічної ефективності ресурсозбереження до- цільно розраховувати за формулою:

К е. еф. $=\sqrt[7]{\mathrm{K} 1 * \mathrm{~K} 2 * \mathrm{~K} 3 * \mathrm{~K} 4 * \mathrm{~K} 5 * \mathrm{~K} 6 * \mathrm{~K} 7}$

де К1 - коефіцієнт природоємності;

К2 - коефіцієнт природної ресурсовіддачі;

К3 - коефіцієнт екологоємності;

К4 - коефіцієнт ресурсоємності процесу;

К5 - коефіцієнт екологічності об'єкту;

К6 - коефіцієнт відходоємкості;

К7 - коефіцієнт екологічності виробництва.

В умовах обмеженості ресурсів та посилення конкурентної боротьби ресурсозбереження забезпечує стійкий розвиток аграрних підприємств, що призводить до необхідності вирішення питань організаційно-кадрового забезпечення суб'єктів господарювання $[6 ; 10]$. Формування ефективної системи менеджменту ресурсозбереження аграрних підприємств повинно включати низку складових, що представлені на рисунку 2.

Культура ресурсозбереження повинна стати обов'язковим елементом загальної культури поведінки особистості і культури професійної діяльності працівників аграрних підприємств. Формування ресурсозберігаючої поведінки персоналу повинно стати елементом корпоративної культури суб'єкта господарювання [6;11].

Основними етапами формування та корегування організаційної культури на аграрному підприємстві, яка містить складову ресурсозбереження, є такі (рис. 3).

\section{ВИСНОВКИ З РОВЕДЕНОГО ДОСЛІДЖЕННЯ I ПЕРСПЕКТИВИ ПОДАЛЬШИХ РОЗВІДОК У ЦЬОМУ НАПРЯМІ}

Сьогодні в сільськогосподарському виробництві спостерігається зниження продуктив- 


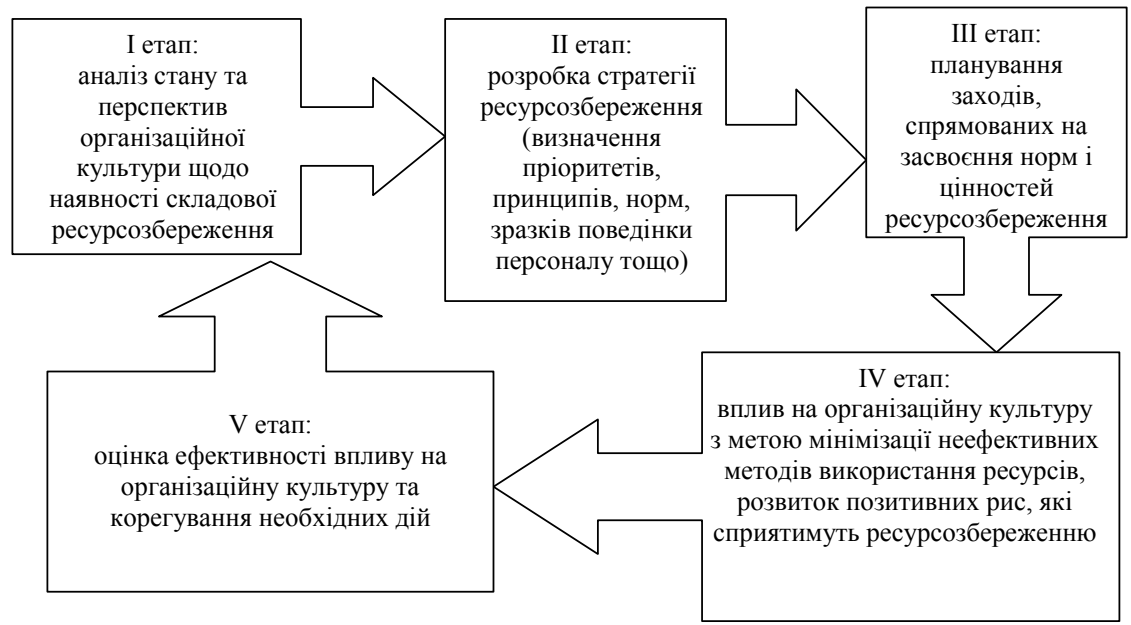

Рис. 3. Основні етапи формування організаційної культури аграрних підприємств,

Ажерело: [6; 12]. яка містить складову ресурсозбереження

ності через деградацію природних ресурсів, посилення біотичних та абіотичних стресів, низьку швидкість заміщення насіння, заподіяння шкоди природній екосистемі внаслідок надмірного та невиборчого використання пестицидів, зміну мікробної динаміки грунту, відсутність якісної зародкової плазми тощо.

За прогнозами екологів та економістів очікується, що в наступні десятиліття зміна клімату не призведе до зниження глобальної доступності продовольства в Україні, але це може посилити залежність нашої держави від імпорту продовольства і послабити рівень продовольчої безпеки.

Актуальні проблеми захисту навколишнього середовища та збереження природних ресурсів в умовах сьогодення набувають великого значення. Все більше аграрних підприємств в Україні турбуються не тільки про одержання прибутку, але і про те, як мінімізувати негативний вплив на навколишнє середовище. Одним iз дієвих напрямів розвитку аграрних підприємств $є$ збільшення ефективності менеджменту ресурсозбереження не тільки в контексті економічної складової, але і екологічної.

$\Lambda$ ітература:

1. Офіційний сайт Всесвітнього фонду природи. Sustainable Agriculture. 2021. URL: https:/ /www.worldwildlife.org/ industries/sustainableagriculture

2. Офіційний сайт Організації економічного співробітництва та розвитку. Agriculture and the environment. 2021. URL: https://www.oecd.org/agriculture/topics/agriculture-and-theenvironment/

3. Офіційний сайт Продовольчої та сільськогосподарської організації ООН. Prospects for the Environment Agriculture and the environment. 2021. URL: https://www.fao.org/3/y3557e/ y3557e11.htm

4. Сайт Органічних ферм. 18 Ways How "Modern" Farming Affects Our World. 2021. URL: http://satavic.org/18-ways-how-modernfarming-affects-our-world/

5. Беляева А.Е. Ресурсосбережение в обеспечении рационального использования природно-ресурсного потенциала. Технологические и организационные аспекты комплексного использования ресурсов угольных месторождений: монографія / под общ. ред. А.А. Голубенко и С.С. Гребенкина. Аонецк: ВИК, 2010. C. $116-137$.

6. Аопушинська О.В. Основні проблеми формування системи менеджменту ресурсозберігаючого розвитку підприємств агропродовольчої сфери та шляхи їх вирішення. Вісник Хмельницького національного університету. Економічні науки. 2020. № 5. С. 286-291.

7. Вдовенко Н.М., Зось-Кіор М.В., Федірець О.В., Гнатенко I.А. Роль енергоринку в менеджменті ресурсозбереження та ресурсоефективності конкурентоспроможних підприємств агропродовольчої сфери. Український журнал прикладної економіки. 2020. № 4. T. 5. C. 222-229.

8. Аячков А.В., Овчаренко Є.І., Ільён В.Ю., Сергієнко С.С. Менеджмент інноваційних проєктів з ресурсозбереження підприємств агропродовольчої сфери на основі діджиталізації. Український журнал прикладної економіки. 2020. № 4. Т. 5. С. 333-338.

9. Маркіна I.А., Зось-Кіор М.В., Сьомич М.I. Менеджмент ресурсозбереження в агропродовольчій сфері: інноваційність виробництва, екологізація землекористування, сталий розвиток 
сільських територій. Аержава та регіони. Серія Економіка та підприємництво. 2020. № 4 (115). C. 54-59.

10. Азядикевич Ю.В. Економічні основи ресурсозбереження: навч. посіб. Тернопіль: Вектор, $2015.76 \mathrm{c}$.

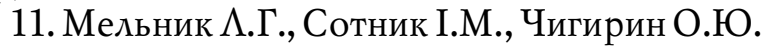
Економіка природних ресурсів: навч. посіб. Суми: Університетська книга, 2010. 346 с.

12. Сотник I.M. Методичні підходи до соціоеколого-економічної оцінки наслідків ресурсозберігаючих трансформацій. Економіка природокористування і охорони довкілля. 2009. C. $152-158$.

\section{References:}

1. The official site of World Wide Fund for Nature (2021), "Sustainable Agriculture", available at: https://www.worldwildlife.org/ industries/sustainable-agriculture (Accessed 10 December 2021).

2. The official site of The Organisation for Economic Co-operation and Development (2021), "Agriculture and the environment", available at: https://www.oecd.org/agriculture/topics/agriculture-and-the-environment/ (Accessed 11 December 2021).

3. The official site of The Food and Agriculture Organization of the United Nations (2021), "Prospects for the Environment Agriculture and the environment", available at: https:// www.fao.org/3/y3557e/y3557e11.htm (Accessed 05 December 2021).

4. The official site of Satavic Farms (2021), "18 Ways How "Modern" Farming Affects Our World", available at: http://satavic.org/18-ways-howmodern-farming-affects-our-world/ (Accessed 11 December 2021).

5. Belyaeva, A.E. (2010), Resursosberezhenie v obespechenyy ratsyonal'noho yspol'zovanyia pryrodno-resursnoho potentsiala [Resource conservation in ensuring the rational use of natural resource potential], VIK, Donetsk, Ukraine.

6. Lopushinska, O.V. (2020), "The main problems of forming the management system of resource-saving development of agro-food enterprises and ways to solve them", Bulletin of Khmelnytsky National University. Economic sciences, vol. 5, pp. 286-291.

7. Vdovenko, N.M. Zos-Kior, M.V. Fedirets, O.V. and Gnatenko, I.A. (2020), "The role of the energy market in the management of resource conservation and resource efficiency of competitive enterprises in the agri-food sector", Ukrainian Journal of Applied Economics, vol. 4, pp. 222-229.
8. Dyachkov, D.V. Ovcharenko, E.I. Ilyin, V. Yu. and Sergienko, S.S. (2020), "Management of innovative projects for resource conservation of agri-food enterprises on the basis of digitalization", Ukrainian Journal of Applied Economics, vol. 4, pp. 333-338.

9. Markina, I.A. Zos-Kior, M.V. and Syomich, M. I. (2020), "Management of resource conservation in the agri-food sector: innovative production, greening of land use, sustainable development of rural areas", State and regions. Economics and Entrepreneurship Series, vol. 4 (115), pp. 54-59.

10. Dzyadykevych, Yu. V. (2015), Ekonomichni osnovy resursozberezhennia [Economic bases of resource saving], Vector, Ternopil, Ukraine.

11. Melnyk, L.G. Sotnyk, I.M. and Chyhyryn, O.Y. (2010), Ekonomika pryrodnykh resursiv [Economics of natural resources], University Book, Sumy, Ukraine.

12. Sotnyk, I. M. (2009), "Methodical approaches to socio-ecological and economic assessment of the consequences of resource-saving transformations", Economics of nature management and environmental protection, pp. 152-158.

Стаття надійшла до редакиї̈ 31.12.2021 p.

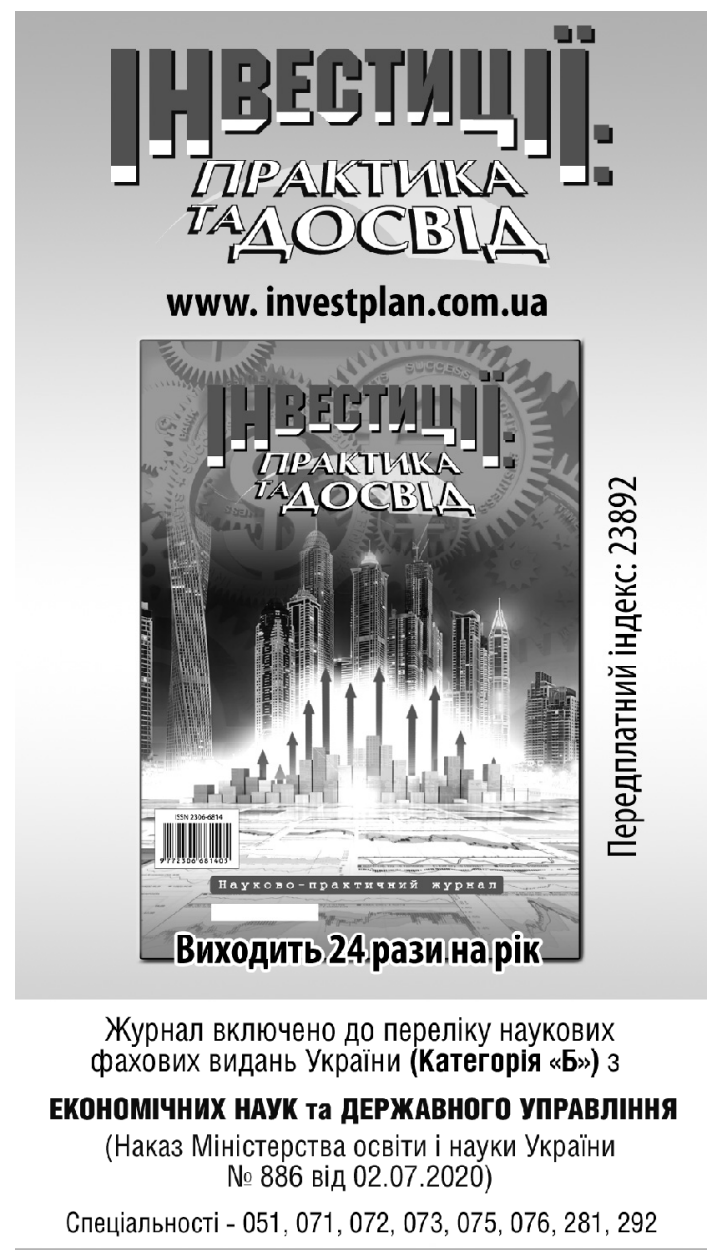

Передплатний індекс 21847 
УAK 657: 658.62

Ю. В. Подмешальська,

к. е. н., Аоцент, доцент кафеАри обліку, аналізу, оподаткування та аудиту, Запорізький національний університет, м. Запоріжжя

ORCID ID: 0000-0001-6353-4542

C. В. Решетніков, магістрант кафедри обліку, аналізу, оподаткування та аудиту, Інженерний навчально-науковий інститут ЗНУ, м. Запоріжжя ORCID ID: 0000-0003-0549-4858

DOI: $10.32702 / 2306-6792.2022 .1 .65$

\title{
ОБЛІК, ОПОААТКУВАННЯ ТА КОНТРОАЬ Е-ЛІКАРНЯНИХ НА ТОРГІВЕАЬНИХ ТА ПРОМИСАОВИХ ПІАПРИЄМСТВАХ
}

\author{
Yu. Podmeshalska, \\ $\mathrm{PhD}$ in Economics, Associate Professor, Associate Professor of the Department of Accounting, \\ Analysis, Taxation and Audit, Zaporizhzhia National University, Zaporizhzhya \\ S. Reshetnikov, \\ Master's student of the Department of Accounting, Analysis, Taxation \\ and Audit, Zaporizhzhia National University, Zaporizhzhya
}

\section{ACCOUNTING, TAXATION AND CONTROL OF E-HOSPITALS IN COMMERCIAL AND INDUSTRIAL ENTERPRISES}

На всіх підприємствах в Україні проводиться оформлення, розрахунок, оплата та виплати податків за лікарняними листами, що надаються власнику працівники. В оплаті лікарняних задіяні кошти як власника, так и Фонду Соціального Страхування, тому доречно правильне використання всіх залучених коштів.

Аля спрощення схеми оформлення випадків тимчасової непрацездатності, прискорення нарахування матеріальної допомоги захворівши особам, зменшення кількість підроблених лікарняних листів, мінімізації кількості штрафів за помилки в оформленні листків непрацездатності 31 жовтня 2021 року українські медичні заклади перейшли на застосування електронних лікарняних.

Мета введення електронних лікарняних - зменшити корупційну можливість придбання лікарняних, прискорити роботу з оформлення та обліку Аокументів, заощадити державні коштів.

Аля позбавлення від паперових носіїв біло створено електронний реєстр листків непрацезАатності - систему, що накопичує, зберігає інформацію про видані і продовжені лікарняні листи і їх врахування. Після запуску та відпрацювання роботи в системі весь потік створення та обліку лікарняних було спрямовано на електронний ресурс. Вивчення та аналіз системи функціонування обліку та оплати лікарняних листів Аозволяє з'ясувати типові помилки при обліку та розрахунках, виявити, застосувати і оцінити способи уникнення помилок, що виникають у процесі.

Практичне значення отриманих результатів полягає в можливості впровадження удосконалених автоматизованих звітів, програм обліку і аудиту лікарняних листів на підприємствах України, що дозводить підвищити якість $\mathrm{i}$ ефективність обліку та аудиту отриманих віА Фондів чи власних коштів на виплати за лікарняними, отримувати своєчасно складені актуальні звіти, звести до мінімуму "людський фактор" в обліку та розрахунках, а також скоротити час перевірки і наАання аудиторського висновку.

Застосування електронних лікарняних - визначна подія з позбавлення від паперових носіїв не тільки у сфері охорони зАоров'я, але й у побудові сучасної електронної системи документообігу, що дозволяє суттєво зменшити витрати бюАжетних коштів зменшуючи корупційні схеми видачі "комерційних" лікарняних та прискорення процесу розрахунку та отримання страхових коштів.

Своєчасна та правильна оплата лікарняних пов'язана з чіткою взаємодією всіх складових, залучених у процес оформлення, розрахунків та звітування за наданими коштами. Вивчення та аналіз системи розрахунку, обліку і аудиту лікарняних на підприємстві дозволить з'ясувати типові помилки при обліку таких розрахунків та виявити, застосувати і оцінити способи уникнення помилок, що допускаються при розрахунках та обліку. Це також сприятиме зміцненню бухгалтерського обліку підприємств, зменшенню витрат на штрафів за помилки в використанні коштів Фонду Соціального Страхування, прискоренню часу оплати лікарняних, дотриманню вимог державних правових актів та постанов. 
At all enterprises in Ukraine, registration, calculation, payment and payment of taxes on sick leaves provided to the owner by employees are carried out. Both the owner and the Social Insurance Fund are involved in the payment of hospital fees, so it is appropriate to use all the funds raised correctly. Timely and correct payment of hospital fees is associated with a clear interaction of all components involved in the process of registration, calculation and reporting on the funds provided.

To simplify the scheme of registration of cases of temporary incapacity for work, speed up the accrual of financial assistance to sick people, reduce the number of forged sick leaves, minimize the number of penalties for errors in the issuance of sick leaves from October 1, 2021, Ukrainian medical institutions switched to electronic hospitals.

The purpose of the introduction of e-hospitals is to reduce the corrupt possibility of purchasing hospitals, to speed up the work on registration and accounting of documents, to save public funds.

Objectives of the study: to analyze the existing electronic system of electronic hospitals from the creation to the transfer of funds to insured workers, identify problems and possible ways to solve them, develop separate proposals to improve accounting, planning, payment, reporting on hospitals in Ukraine.

The practical significance of the obtained results lies in the possibility of implementing improved automated reports, accounting and audit programs for sick leaves at Ukrainian enterprises, which will improve the quality and efficiency of accounting and auditing of funds received from the Funds or own funds for hospital payments. minimum "human factor" in accounting and calculations, as well as reduce the time of verification and submission of the audit opinion.

The use of e-hospitals is a significant event in the disposal of paper not only in health care, but also in the construction of a modern electronic document management system, which can significantly reduce budget expenditures by reducing corrupt schemes of issuing "commercial" hospitals and speeding up the calculation and receipt process. insurance funds.

The study and analysis of the system of calculation, accounting and audit of hospitals in the company will identify common errors in accounting for such calculations and identify, apply and evaluate ways to avoid errors in calculations and accounting. It will also help strengthen the accounting of enterprises, reduce the cost of fines for errors in the use of the Social Insurance Fund, speed up the time of payment of sick leave, compliance with state legal acts and regulations.

Ключові слова: електроннийреєстрмедичих висновків, електронийлікарняний, фонд сочіального страхування, міністерство охорони здоро' вя Украӥни, застрахована особа, страхувальник.

Key words:electronic register of medical conclusions, electronic bospital, social insurance fund, ministry of health of Ukraine, insurance, insurance.

\section{ПОСТАНОВКА ПРОБЛЕМИ}

На всіх підприємствах в Україні проводиться оформлення, розрахунок, оплата та виплати податків за лікарняними листами, що надаються власнику працівники. В оплаті лікарняних задіяні кошти як власника, так и Фонду Соціального Страхування, тому доречно правильне використання всіх залучених коштів. Своєчасна та правильна оплата лікарняних пов'язана з чіткою взаємодією всіх складових, залучених у процес оформлення, розрахунків та звітування за наданими коштами.

\section{АНАЛІЗ ОСТАННІХ ДОСЛІДЖЕНЬ І ПУБЛІКАЦІЙ}

Скріпкина Е., Ушакова $\Lambda$, Калашнікова $\Lambda$. у своїх працях досліджували та послідовно проводили покроковий опис від отримання лікарняного листа, оформлення, розрахунку до його бухгалтерського проведення та звітування. Скрипкіною Е. ретельно проведено опис дії комісій по соціальному страхуванню на підприємствах різних типів власності, порядок призначення допомоги застрахованій особі за лікарняним листом. Ушакова $\Lambda$. надала працю за розрахунками лікарняних з теоретичної сто- рони та з практичної, провела опис послідовності виплат лікарняних. Калашнікова $\Lambda$. висвітлювала методики обліку та звітності за лікарняними за вимогами держаних нормативних документів, актів та постанов.

\section{META CTATTI}

Метою статті є дослідження та удосконалення системи обліку і аудиту розрахунків лікарняних листів на вітчизняних підприємствах різних форм власності з використанням власних коштів та коштів Фонду Соціального Страхування. Після переходу на використання електронних листків непрацездатності в населення, відповідальних робітників бухгалтерій, керівництва, профсоюзних діячів виникли питання щодо здійснення на практиці механізму оплати лікарняних на підприємствах

Кабінет Міністрів України (постанова від. № 32817.04.2019р.), Верховна Рада України (постанова № 1192-IX03.02.2021р.), Міністерство охорони Здоров'я України (наказ № 1066 від 01.06.2021р.) описують методику оформлення, нарахування, оплати, врахування листків непрацездатності з використанням електронного реєстру. 
Таблиця 1. Форма журналу обліку лікарняних

\begin{tabular}{|c|c|c|c|c|c|c|c|c|c|c|c|}
\hline \multirow[b]{2}{*}{$\begin{array}{c}\text { № } \\
\text { П/П }\end{array}$} & \multirow[b]{2}{*}{ 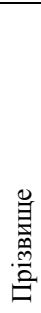 } & \multirow[b]{2}{*}{$-\underline{\underline{a}}$} & \multirow[b]{2}{*}{ 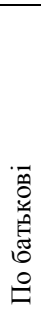 } & \multirow[b]{2}{*}{ 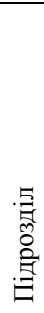 } & \multirow[b]{2}{*}{ 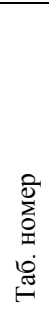 } & \multicolumn{3}{|c|}{$\begin{array}{c}\text { Дані листка } \\
\text { непрацездатності }\end{array}$} & \multicolumn{2}{|c|}{$\begin{array}{c}\text { Період } \\
\text { непраце- } \\
\text { здатності }\end{array}$} & \multirow{2}{*}{ 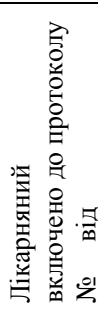 } \\
\hline & & & & & & e & 造 & 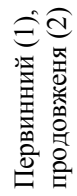 & 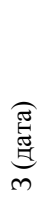 & 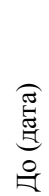 & \\
\hline 1 & 2 & 3 & 4 & 5 & 6 & 7 & 8 & 9 & 10 & 11 & 12 \\
\hline
\end{tabular}

Ажерело: складено і запропоновано автором на підставі нормативних інформаційних джерел.

Аля об'єднання інформації з різних державних законодавчих актів, освітлення послідовності роботи з електронними листками (отримання, обліку, оформлення, розрахунків, відрахувань) розглянемо, що повинні знати відповідальні особи та застраховані працівники.

\section{ВИКЛАД ОСНОВНОГО МАТЕРІАЛУ}

Оформлення е-лікарняного. В разі захворювання працівник повинен звернутися до медичного закладу до свого сімейного лікаря, 3 яким в нього укладена угода на медичне обслуговування. Сімейний лікар оглядає особу та в разі виявлення симптомів захворювання призначає лікування, оформлює лист непрацездатності в електронній мережі і підписує лист своїм е-підписом. Створений електронний лист підтверджує факт непрацездатність протягом вказаного в е-реєстрі листків непрацездатності періоду. Сімейний лікар вносить до реєстру назву підприємства, на якому працює захворі-

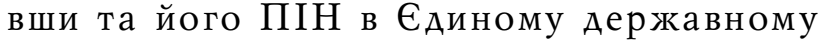
реєстрі. Підтвердженням правильності оформлення лікарняного в системі охорони здоров'я є отримання смс-повідомлення від е-системи MO3 що містить 16 значний номером медичного висновку про тимчасову непрацездатність (далі МВ). Якщо смс-повідомлення відсутнє потрібно перевірити номер телефону в системі. Смс-повідомлення підтверджує, що лист створено потрібній захворівшій людині.

Аруге смс-повідомлення від ПФ України підтверджує успішного формування е-лікарняного. Смс-повідомлення отримують тільки зареєстровані в Реєстрі застрахованих особи, списки яких подають роботодавці.

Випадки, в яких не приходять смс з повідомленнями від МО3:

1. Неправильний телефонний номер.

2. Змінився номер паспорта.

3. Помилка при створені висновку.

Випадки в яких не приходять смс з повідомленнями від ПФ:
1. Відсутній особистий кабінет.

2. Неправильний телефонний номер.

3. Особа не працевлаштована, або не сплачує ECB.

4. Особа не є застрахованою, або їі данні відсутні.

5. Роботодавець не вніс данні до ПФ.

Підставою для нарахування виплат $є$ формування запису з унікальним номером - єдиного реєстраційного номеру листка непрацездатності.

Роботодавцю доступний перегляд інформації з е-лікарняного працівника (тільки за основним місцем роботи) в е-кабінеті страхувальника в відповідному реєстр, де виводиться інформація за лікарняними. Інформація надається по податковому номеру фізичної особи працівника. Роботодавець не має отримувати даних про діагнозом працівника.

Застрахована особа (працівник) може отримати інформацію стосовно е-лікарняного через свій особистий кабінет у ПФ.

Роботодавець може переглянути:

- реєстраційний номер е-лікарняного;

- П I Б;

- номер картки платника податків (для застрахованих осіб);

- період лікування (коли був відкритий та закритий лікарняний);

- причину непрацездатності робітника.

Коди причин непрацездатності робітників в е-лікарняних відрізняються від кодів для паперових лікарняних і зазначаються від 1 до 12. Коди (причини) можна дізнатися в повідомленні ФСС.

Е-лікарняний одразу після реєстрації може бути переглянутим в особистому кабінеті робітника чи страхувальника на ресурсі е-послуг ПФ України і при правильному оформленні має статус "закритий". Застосувати його для розрахунку коштів роботодавець може після завершення визначеного періоду непрацездатності (тільки після зміни статусу е-лікарняного на "готово до сплати"). 
Оплатити перші п'ять днів за е-лікарняним та виплати допомогу за кошт ФСС (призначити матеріальне забезпечення) можна тільки після закриття лікарняного. Інформація про те, що е-лікарняний було закрито страхувальнику автоматично не відсилається на пошту або стільниковий номер, тому потрібно слідкувати за цією подією.

Аля підприємств, що використовують автоматичні системи для обліку робочого часу та розрахунку заробітної плати потрібно втручання фахівців з програмного забезпечення для вирішення своєчасного облік закритих лікарняних. Аля тих хто не має автоматичних систем можна запропонувати ведення паперових документів для обліку робітників, що отримали лікарняні.

Не більш ніж за 10 днів 3 дня закінчення лікарняного роботодавець повинен призначити працівнику допомогу за готовим до сплати е-лікарняним і ще 5 робочих днів після призначення надається для надання заяви-розрахунку до ФСС.

Роботодавець, отримавши інформацію, одразу має змогу сформувати заяву-розрахунок для ФСС, щоб отримати кошти. Аані з заявирозрахунку одразу отримує ФСС.

Послідовність дій (призначення, розрахунок, виплати) за е-лікарняними не змінилась, але якщо роботодавець має листки непрацездатності паперові та електроні, то він повинен подати дві заяви-розрахунки: за паперовими i е-лікарняними (в е-лікарняних нема серії та інші коди причин тимчасової непрацездатності).

Заяву-розрахунок за лікарняними можливо подати за допомогою програмного забезпечення, застосувавши електронний підпис/ печатку, або в паперовому виді. Роздруковувати та зберігати електронні лікарняний не потрібно.

Нарахування й отримання коштів за електронними лікарняними. Рішення про доцільність виплат коштів за лікарняним приймає комісія (уповноважений) із соціального страхування (відповідно до Положення № 13). Комісія видає один протокол за всіма лікарняними, що подавалися на розгляд (паперовими, електронними).

Комісія приймає рішень про призначення або відмову у призначенні виплат, а також про повне або часткове їх припинення. Рішення комісії затверджуються протоколом. Кошти за лікарняним виплачуються у найближчі дні виплати зарплати на підприємствi.
Причини, що унеможливлюють призначення виплат:

1. Травма була отримано під час скоєння ним злочину.

2. Умисне пошкодження здоров'я або симуляція хвороби.

3. Арешт застрахованого робітника, проведення слідчих дій.

4. Мікування за рішенням суду.

5. Сп'яніння застрахованої особи або дій, або дії в стані сп'яніння.

6. Відпустка за власні кошти.

7. Творча відпустка.

8. Навчальна відпустка.

9. Недотримання режиму, що встановив лікарем, або неявка без поважної причини на призначений час на медичний огляд.

10. Помилки при заповненні листка непрацездатності.

Терміни оплати тимчасової непрацездатності.

Перші п'ять днів лікарняного оплачує роботодавець (якщо захворювання робітника не пов'язане $з$ нещасним випадком на виробництві), а $з$ шостого дня до одужання, або до визначення працівнику інвалідності оплачує Фонд.

Иікарняний з догляду за хворою дитиною віком до 14 років виплачує Фонд за всі дні (але не більше ніж за 14 днів), а у разі лікування дитини у стаціонарних умовах - за весь час лікування хворої дитини у стаціонарних умовах.

Розмір допомоги за лікарняним.

Страховий стаж (далі Стаж) застрахованих робітників використовується при розрахунках допомоги за лікарняними. Відсоток розміру середньої зарплати (або доходу) встановлюють у такому розмірі:

1) $50 \%$ від зарплати (доходу) - стаж менше трьох років;

2) $60 \%$ від зарплати (доходу) - стаж більше трьох та менше п'яти років;

3) 70 \% від зарплати (доходу) - стаж більше п'яти та менше восьми років;

4) $100 \%$ від зарплати (доходу) - стаж більше восьми років;

5) 100 \% від зарплати (доходу) - робітникам пільгових категорій.

Розмір допомоги у відсотках (розділ "назначена допомога") та кількість днів лікарняного, до сплати вказує відповідальна особа у протоколу комісії. Аані про стаж працівника надає відділ кадрів підприємства або уповноважена власником особа.

Протокол комісії передається бухгалтеру роботодавця для розрахунку, нарахування та 
оплати за лікарняним. Бухгалтер додає інформацію про заробітну плату за розрахунковий період та розмір вирахуваної матеріальної допомоги.

Розрахунок лікарняних.

Розрахунки розміру та нарахування лікарняних виконує роботодавець у тому місяці, в якому надійшов до бухгалтерії оформлений протокол та документи для призначення допомоги за лікарняним.

Розрахунки лікарняних проводяться у такій послідовності:

1. Визначається розрахунковий період.

2. Визначається кількість днів в розрахунковому періоді.

3. Розраховується загальна сума зарплата період.

4. Розраховується середньоденна зарплата.

5. Визначається максимальний розмір середньої зарплати за один день.

6. Визначається розмір денної виплати за лікарняним.

7. Розраховується кошти за перші пять днів лікарняного.

Иікарняні розраховуються шляхом множення денної (годинної) виплати на кількість днів (годин), які підлягають сплаті.

$\mathrm{B}=\mathrm{AB} \times \mathrm{K}$

де Б - кошти за лікарняним;

$\triangle \mathrm{B}$ - денна виплата;

$\mathrm{K}$ - кількість робочих днів (годин), до сплати.

Аенна виплата допомоги розраховується як: $A B=3 \Pi c p \times C \div 100$,

де ЗП ср - розмір середньоденної зарплати;

С - відсоток середньої зарплати.

Розрахунок середньоденної зарплати.

Середньогодинну заробітну плату при розрахунку сум допомоги за лікарняним листком використовують у випадках коли:

1) на підприємстві ведеться облік часу роботи;

2) облік часу роботи працівників обраховується в годинах;

3) у місяцях, що беруться до розрахункового періоду, за які розраховується середня зарплата, чи в проміжку часу, протягом якого оплачуються лікарняні, встановлено неповний робочий день.

У іншому випадку застосовують середньоденну зарплату.

Середньоденну (середньогодинну) зарплату розраховують за формулою:

$3 \Pi \mathrm{cp}=3 \Pi \div \mathrm{P} \Pi$

де 3П - сума зарплати у період розрахунків;
РП — кількість відпрацьованих днів (годин). Аля коректного розрахунку визначають:

— кількість робочих днів (годин) розрахункового часу;

- розмір виплат робітнику, що використовуються для розрахунку середньої зарплати.

Розрахунковий період середньої зарплати.

Середня зарплата береться за розрахунковий період за тим місцем роботи робітника, де він працював та сплачував внески до Фонду.

Розрахунковим періодом для застрахованих осіб $є$ останні 12 календарних місяців (з 1-го до 1-го числа) попередніх місяцю, в якому робітник захворів.

Якщо особа працювала менше 12 календарних місяців, то середня зарплата береться за відпрацьовані календарні місяців (з 1-го до 1го числа) перед місяцем хвороби. 3 розрахунку виключаються ті місяці, що були не повністю відпрацьовані особою з причин:

1) знаходження робітника на лікарняному;

2) відпустки вагітних та породіль;

3) відпустки робітників, що доглядають за дитиною до 3-х років.

Середньоденна заробітна плата.

Ао розрахунку середньоденної плати включаються виплати:

1) виплати, нараховані працівнику за відпрацьований час (відпускні не беруть участі);

2) виплати, що включаються до фонду оплати праці та до бази нарахування (утримання) ECB;

При розрахунках потрібно враховувати обмеження розміру середньоденної зарплати, яка не повинна бути більшою за максимальну величину бази нарахування $\mathrm{CCB}$ у розрахунку на один день.

Час, що підлягає оплаті за лікарняним.

Якщо хвороба працівника підтверджена лікарняним, то оплаті беруть усі робочі дні, що не були ним відпрацьовані за графіком роботи. Неробочі дні, дні свят та вихідні, що є у періоді хвороби не оплачуються.

Фінансування лікарняних за рахунок коштів ФСС.

Аля отримання грошової допомоги від Фонду страхувальник відкриває окремий поточний рахунок для страхових коштів у банку відповідно до Інструкції.

Форма заяви-розрахунку для отримання коштів на виплату допомоги за лікарняними однакова для паперових і електронних лікарняних. Е-лікарняні не мають серії, а причини непрацездатності відмінні від паперових, тому заповнення заяви-розрахунку за е-лікарняними має особливості. У зв'язку із цим за паперо- 
вими і е-лікарняними подають дві окремі заяви-розрахунку.

Формування заяви-розрахунку за е-лікарняним

Заяви-розрахунки за паперовими і е-лікарняними надаються однакові. Заяву-розрахунок можна подати в електронній мережі за допомогою програмного забезпечення або в паперовій формі.

У заяві-розрахунку:

- на лицьовій стороні - зазначаються реквізити страхувальника-роботодавця та інформація про нараховані суми лікарняних (нарахована сума);

- на зворотному боці проводиться детальна інформація щодо нарахованих коштів по кожному працівнику.

Заява-розрахунок заповнюється у двох примірниках. Один примірник залишається у страхувальника, другий подається до Фонду. Заява-розрахунок підписується керівником підприємства, головним бухгалтером та засвідчується печаткою підприємства.

Фонд може провести перевірку доцільності нарахування підприємством допомоги за лікарняними. За відсутності виявлення порушень перераховуються кошти не більше ніж за 10 робочих днів від надходження від страхувальника до ФСС заяви-розрахунку.

У разі виявлення фахівцями робочих органів Фонду помилок у заяві-розрахунку, у тому числі пов'язаних помилковим розрахунком допомоги, за якою фінансування не проводилося, фінансові (штрафні) санкції не застосовуються, тому що страхові кошти не використовувались.

Виплата лікарняних.

Кошти за перші п'яти днів лікарняного переводяться працівникові в найближчий після призначення день виплати заробітної плати, не чекаючи надходження коштів Фонду. Перераховуючи кошти працівнику, роботодавець сплачує обов'язкові платежі у встановлені в державі термін. Отримавши кошти від Фонду на окремий спеціальний рахунок у банківському закладі, страхувальник-роботодавець перераховує лікарняні в строк, але не пізніше дати виплати зарплати на підприємстві.

Страхувальник перераховує частину отриманих від Фонду коштів на сплату обов'язкових платежів, що утримуються з нарахованих лікарняних.

Бухгалтерський облік лікарняних.

У бухгалтерському обліку операція з нарахування лікарняних, що виплачується за раху- нок коштів ФСС, відображається проведенням: дебет субрахунку 378 "Розрахунки з державними цільовими фондами" кредит субрахунку 663 "Розрахунки за іншими виплатами".

Сума оплати перших п'яти днів тимчасової непрацездатності у бухгалтерському обліку відображається за кредитом субрахунку 663 "Розрахунки з інших виплат" у кореспонденції з дебетом субрахунку 94 "Інші витрати операційної діяльності. Однак можуть використовуватися й інші рахунки витрат - 91 "Загальновиробничі витрати", 92 "Адміністративні витрати", 93 "Витрати на збут".

ЄАиний соціальний внесок.

Всі суми нараховані за лікарняний включаються до бази для нарахування та утримання єдиного соціального внеску (далі ЕСВ).

Розмір ЕСВ складає:

$-22 \%$ - для підприємств та фізичних осіб щодо нарахувань на суми лікарняних працівників;

- 8,41\% - для підприємств щодо нарахувань на суми лікарняних, нарахованих працівникам-інвалідам (п. 3.11 Інструкції № 21-5)

$-5,3,5,5 \%$ - для підприємств де працюють інваліди, а кількість інвалідів становить $25-50 \%$ загальної чисельності робітників, та за умови, а сумарна заробітна плата складає не менше 25 \% загальних витрат коштів на оплату праці.

Иікарняні враховуються при визначенні максимальної величини бази нарахування ЄСВ "Перехідні" лікарняні для цілей оподаткування ЄСВ розподіляються за місяцями, за які вони нараховані, та порівнюються 3 максимальною величиною бази нарахування $\mathrm{ECB}$, що діяла в періоді, за які здійснюється нарахування. При порівнянні з максимальною величиною бази для нарахування $\mathrm{ECB}$ оплата перших п'яти днів та допомога 3 тимчасової непрацездатності враховуються в останню чергу після зарплати та винагороди за цивільно-правовим договором (п.п. 4.3.2 Інструкції № 21-5).

Податок на прибуток фізичних осіб.

Суми оплати перших п'яти днів за рахунок коштів роботодавця та допомоги з тимчасової непрацездатності вкдючаються до загального оподатковуваного доходу працівника у складі заробітної плати та оподатковуються за ставками п. 167.1 ПКУ (18\%).

У зв'язку з цим:

- при визначенні бази оподаткування зменшуються на суму ЄСВ у частині утримань та на суму податкової соціальної пільги (за наявності права на неї); 
- враховуються щодо граничного розміру доходу, що дає декларація про податкову соціальну пільгу.

Власник зі свого поточного фонду сплачує ЕСВ та податок на доходи фізичних осіб (ПАФО) - утримання з суми оплати перших п'яти днів непрацездатності. А ЕСВ щодо утримань та ПАФО із суми допомоги 3 тимчасово непрацездатності - перераховує 3 окремого поточного рахунку у банку, на який отримує фінансування з Фонду.

\section{ВИСНОВОК}

Застосування електронних лікарняних визначний подія з позбавлення від паперових носіїв не тільки у сфері охорони здоров'я, але й у побудові сучасної електронної системи документообігу, що дозволяє суттєво зменшити витрати бюджетні кошти зменшуючи корупційні схеми видачі "комерційних" лікарняних та прискорення процесу розрахунку та отримання страхових коштів.

Вивчення та аналіз системи розрахунку, обліку і аудиту лікарняних на підприємстві дозволить з'ясувати типові помилки при обліку таких розрахунків та виявити, застосувати i оцінити способи уникнення помилок, що допускаються при розрахунках та обліку. Це також сприятиме зміцненню бухгалтерського обліку підприємств, зменшенню витрат на штрафів за помилки в використанні коштів Фонду Соціального Страхування, прискоренню часу оплати лікарняних, дотриманню вимог державних правових актів та постанов.

\ітература:

1. Аеякі питання організації ведення Електронного реєстру листків непрацездатності та надання інформації з нього. Постанова Кабінету Міністрів України від 17.04.2019 р. № 328. URL: https://zakon.rada.gov.ua/laws/show/3282019-\%D0\%BF\#Text

2. Про заходи щодо запровадження Електронного реєстру листків непрацездатності: Постанова ВРУ від 03.02.2021 р. № 1192-IX. URL: https://zakon.rada.gov.ua/laws/show/1192IX\#Text

3. Аеякі питання формування медичних висновків про тимчасову непрацездатність та проведення їхньої перевірки. Наказ Міністерства Охорони Здоров'я України від 01.06.2021 р. № 1066. URL: https://zakon.rada.gov.ua/laws/ show/z0728-21\#Text

4. Бутинець Ф.Ф., Олійник О.В., Шигун М.М., Шулепова С.М. Організація бухгалтерського обліку: навч. посібник. Житомир: ЖІTI, 2001. 576 с.
5. Макаренко А.П., Меліхова Т.О., Бескоста Г.М. Організація і методика аудиту: навч.метод. посібник. Запоріжжя: ЗАІА, 2015. 190 с.

References:

1. Cabinet of Ministers of Ukraine (2019), "Some issues of the organization of maintaining the Electronic Register of sick leaves and providing", available at: https://zakon.rada.gov.ua/laws/ show/328-2019-\%D0\%BF\#Text (Accessed 25 Sept 2021).

2. Verkhovna Rada of Ukraine (2021), "On measures to introduce the Electronic Register of Incapacity for Work", available at: https:// zakon.rada.gov.ua/laws/show/1192-IX\#Text (Accessed 30 Sept 2021).

3. Ministry of Health of Ukraine (2021), "Some issues of forming medical reports on temporary incapacity for work and conducting their inspection, available at: https://zakon.rada.gov.ua/laws/ show/z0728-21\#Text (Accessed 31 Sept 2021).

4. Butynets', F. F., Olijnyk, O. V., Shyhun, M. M. And Shulepova, S. M. (2001), Orhanizatsiia bukhhalters'koho obliku [Organization of accounting], ZhITI, Zhytomyr, Ukraine.

5. Makarenko, A.P. Melikhova, T.O. and Beskosta, H. M. (2015), Orhanizatsiya i metodyka audyt [Organization and method of audit], ZDIA, Zaporizhzhya, Ukraine.

Стаття надійила до редакчї 21.12.2021 p.

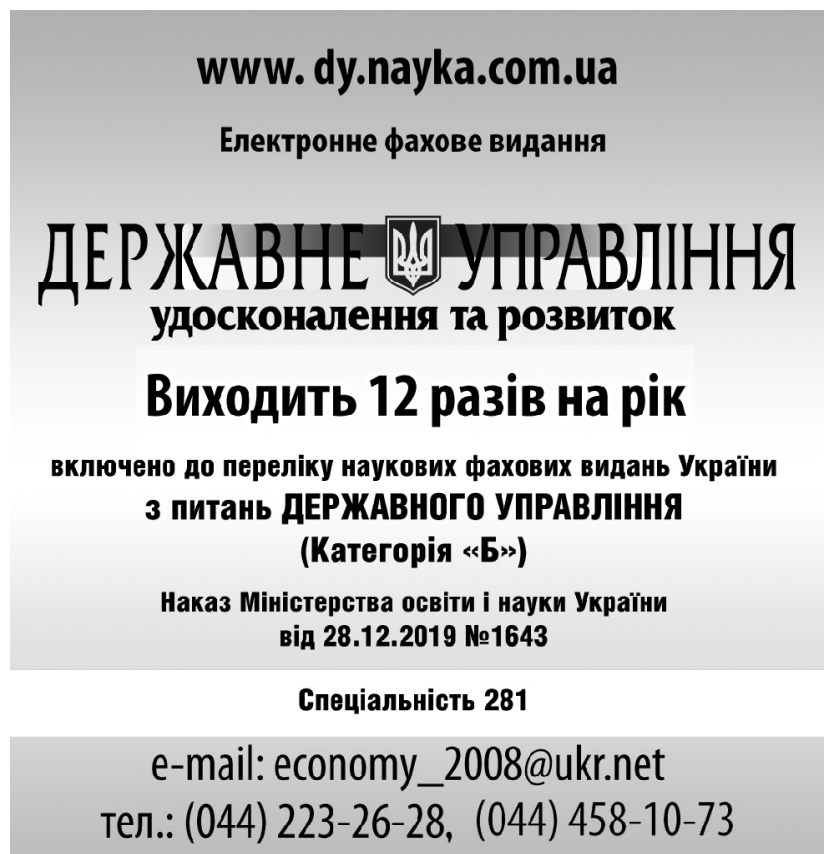


УАК 339.13.027:631.11

Н. М. Чернікова,

к. е. н., Аоцент, доцент кафеАри менеджменту імені I.А. Маркіної,

Полтавський Аержавний аграрний університет, м. Полтава

ORCID ID: 0000-0002-0079-6411

A. Р. Зеленський,

зАобувач вищої освіти спеціальності "Менеджмент",

Полтавський Аержавний аграрний університет

ORCID ID: 0000-0002-5219-6493

DOI: $10.32702 / 2306-6792.2022 .1 .72$

\title{
АНТИКРИЗОВЕ УПРАВАІННЯ \\ СІЛЬСЬКОГОСПОААРСЬКИМИ ПІАПРИСМСТВАМИ В УМОВАХ ПАНАЕМІЇ COVID-19
}

\author{
N. Chernikova, \\ $\mathrm{PhD}$ in Economics, Associate Professor, Associate Professor the Department of Management \\ named after I. A. Markina, Poltava State Agrarian University, Poltava \\ D. Zelenskyi, \\ Applicant for higher education specialty Management, Poltava State Agrarian University, Poltava

\section{ANTI-CRISIS MANAGEMENT OF AGRICULTURAL ENTERPRISES IN CONDITIONS OF COVID-19 PANDEMIC}

У статті розглянуто актуальні питання антикризового управління в умовах сучасного функціонування аграрного підприємства. Розглянуто сутність поняття "криза" та "антикризове управління" в роботах вітчизняних та зарубіжних вчених. 3Аійснено аналіз різних наукових напрацювань 3 питань антикризового управління сільськогоспоАарськими підприємствами. АосліАжено проблеми, які виникають у сільському господарстві піА час пандемії, особливості антикризового управління в таких умовах, а також запропоновано шляхи удосконалення ведення агробізнесу. Зосереджено увагу на основних процесах антикризового управління, що Аозволяє максимально ефективно попередити та/або подолати кризу у сільськогосподарському підприємстві. Визначено комплекс заходів, які сприятимуть забезпеченню ефективності антикризового управління та досягненню його цілей в умовах та після пандемії, розроблений спираючись на досвіА одного з провідних аграрних підприємств України.

The article considers topical issues of crisis management in conditions of modern functioning of the agrarian enterprise. Considered the essence of the concept of "crisis" and "crisis management" in the works of domestic and foreign scientists. The analysis of various scientific developments with issues of anti-crisis management of enterprises in various industries and, in particular, agricultural enterprises. Set common for different countries of the world problems related to agriculture during the pandemic. The analysis of the state of the agricultural sector for the last ones was carried out five years and proved the strategic importance of this industry for the economic security of the country and its individual regions. The problems arising in agriculture during the pandemic, which are mainly related to supply and marketing activities and the effectiveness of anti-crisis management. Features of anti-crisis management are established agricultural enterprises in modern conditions, as well as proposed ways of improving agribusiness. Focus on the main crisis management processes, which allows the most effective prevention and/or overcome the crisis in the agricultural enterprise, and namely: pre-crisis management, crisis management, timeliness managerial influence, management of crisis exit processes, stabilization condition, and leveling deviations. A set of measures has been identified to contribute to the effectiveness of crisis management and achieving its goals in the conditions and after the pandemic, developed based on the experience of one of the leading agricultural enterprises of Ukraine. Done conclusion about the higher resilience of large agricultural enterprises to a crisis caused by the global pandemic, due to the conduct of preventive 
measures, creation of an anti-crisis team of specialists, and a clear plan of action during the crisis. Use is suggested anticrisis measures developed for the agricultural enterprise similar enterprises of Ukraine, as well as state direction support for small and medium-sized farms.

Ключові слова: криза, сільськогосподарське виробничтво, антикризове управління, прочес, ефективність.

Key words: crisis, agricultural production, anti-crisis management, process, efficiency.

\section{ПОСТАНОВКА ПРОБЛЕМИ}

В умовах глобальної кризи значною мірою постає питання антикризового менеджменту, адже діяльність підприємств дозволяє підтримувати чіткий економічний та фінансовий клімат, забезпечувати людей благами та розвивати суспільство. Особливо важливою галуззю для суспільства завжди було сільське господарство. Саме ця галузь забезпечує їжею населення та є запорукою розвитку багатьох інших сфер народного господарства. Особливою перевагою ведення сільського господарства в Україні є його зручне географічне розташування, що дозволяє використовувати ресурсний потенціал максимально ефективно. Проте в умовах світової пандемії, спричиненої Covid19, сільське господарство як і інші галузі опинилось під впливом ще одного несприятливого фактору, у зв'язку з чим виникла необхідність привернення додаткової уваги до забезпечення ефективності функціонування цієї галузі в умовах, що склалися.

\section{АНАЛІЗ ОСТАННІХ ДОСЛІДЖЕНЬ І ПУБЛІКАЦІЙ}

Питання антикризового управління у різних галузях та сферах діяльності вже багато років привертають увагу вітчизняних та закордонних вчених, що зумовлено нестабільністю та мінливістю зовнішнього середовища. Такі вчені як Батрак O.B., Тарасенко I.O. [1], Горобець I.I. [3], Ковалевська А.В. [5], Манжос С. [6], Самойленко В.В. [10] та ін. розглядають кризу як вихід зі стабільного становища та як переломний момент у будь-якій усталеній діяльності. Особливість кризи спричиненої Covid-19, як і інших криз природного походження, полягає у їі непередбачуваності, але настання саме таких обставин зумовлює необхідність розробки програм виходу 3 уже існуючих кризових умов та попереджувальних заходів на випадок ймовірного настання несприятливих подій у майбутньому. Зазначеним питанням присвячено робо- ти багатьох науковців та практиків: Прокопишин О.С. [9], Стешенко О.А., Масалигіна В.В. [11], Тулуш М.O., Радченко О.А. [12], Циган P.M. [13], Miroshnychenko O. [14], Ker P.A., Biden S. [15], Shihua Zeng [16]. Проте поки не достатньо вивченими $є$ проблеми сільськогосподарських підприємств, пов'язані з настанням та довгою тривалістю пандемії та, відповідно, немає чіткої програми щодо виходу з коронакризи.

\section{МЕТА ДОСЛІДЖЕННЯ}

Метою дослідження $є$ вивчення проблем функціонування сільськогосподарських підприємств в умовах пандемії та розробка заходів щодо подолання кризових явищ в їх діяльності в цей період. Аля досягнення мети вирішувались такі завдання:

довести важливість аграрної галузі для економіки України, а також сильні сторони та загрози, для сільськогосподарських підприємств викликані пандемією Covid-19;

дослідити процеси антикризового менеджменту з теоретичної та практичної точок зору;

визначити переваги великих агрохолдингів у протистоянні кризовим явищам;

запропонувати комплекс заходів щодо подолання негативного впливу коронакризи на діяльність сільськогосподарських підприємств.

\section{ВИКЛАД ОСНОВНОГО МАТЕРІАЛУ ДОСЛІДЖЕННЯ}

Аналіз літературних джерел [11-16] показав, що проблеми сільського господарства у період пандемії, є актуальними як для України, так і для всього світу. Наприклад, у Канаді, де гостро стоїть питання про впровадження систем антикризового менеджменту у сільське господарство, на підтримку галузі у 2019 році було виділено понад 2,6 млрд дол. Аослідження доводять також схожість проблем у веденні агробізнесу в цей період для різних країн світу, до яких слід віднести: ускладнення експортно- 
імпортних операцій, закриття ринків, обмеження при виробництві продукції тваринництва через особливості виробничого процесу та необхідність дотримання карантинних вимог, неможливість експорту проАукції через аграрні біржі, зниження прибутковості сільськогосподарських підприємств та можливостей оновлення сільськогосподарської техніки тощо. Світова практика переконує в необхідності розробки антикризових заходів задля забезпе-

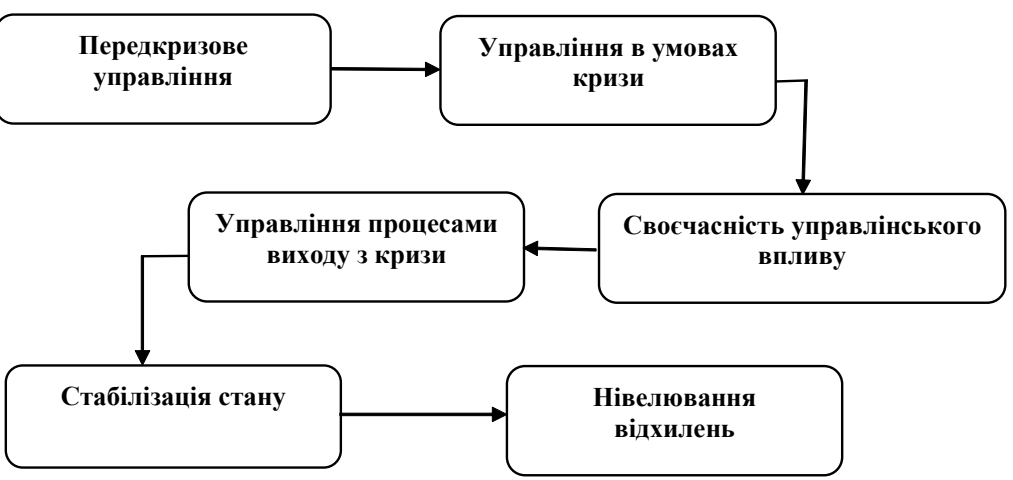

Рис. 1. Процеси антикризового управління

чення людства продовольством, підвищення техніко-технологічного рівня аграрної галузі та зайнятості населення.

Станом на 2021 рік сільськогосподарські угіддя в Україні займають 42 млн гектарів, або 70 \% загального фонду країни, українські сільгоспвиробники постачають свою продукцію в 185 країн світу. За даними уряду та дослідницьких центрів, станом на кінець року агросектор займає майже 20 \% ВВП України і приносить майже 40 \% валютної виручки, у цьому секторі зайнято 17,3 \% від усіх працівників УКраїни [2]. Водночас статистичні дані свідчать про зростання відсотку збиткових сільськогосподарських підприємств з 13,7\% у 2017 та 2018 роках до 16,9\% та 17,3\% відповідно у 2019 та 2020 роках [7]. Отже, можна зробити висновок, що цей сектор є критично важливим для української економіки, тому антикризові заходи в аграрному виробництві на сьогодні є суттєвою проблематикою.

Основні проблеми, з якими зіткнулись вітчизняні сільськогосподарські підприємства під час коронакризи, пов'язані переважно із: забезпеченням оборотними засобами, оскільки спостерігається висока залежність країни від імпорту добрив та захисту рослин (на 70 \%), насіннєвого матеріалу (на 50-85 \%, залежно від виду сільськогосподарської культури), сільськогосподарської техніки (майже на 70 \%); зі збутом готової продукції (особливо експортоорієнтованої); відсутністю антикризових менеджерів та плану антикризових дій; все ще достатньо низьким рівнем цифровізації та автоматизації бізнес-процесів в даній галузі та ін. [8].

Позитивним моментом $€$ те, що сільське господарство в цілому менше страждає від коронакризи ніж інші сфери та галузі діяльності, але саме її стратегічна важливість для економічної безпеки нашої країни зумовлює необхідність детально дослідити проблеми ведення цієї галузі в умовах пандемії, намітити шляхи виходу з кризи та післякризові заходи.

Процеси антикризового управління, спрямовані на протидію кризовій ситуації в максимально короткі строки, зображено на рисунку 1.

Аналіз усіх процесів антикризового управління та рівня взаємодії між ними є важливим кроком для покращення цих механізмів. Таке дослідження було проведено на базі сільськогосподарського підприємства на базі ТОВ "Астарта Прихоролля", яке є дочірнім підприємством агропромислового холдингу "АстартаКиїв", одного з найпотужніших агрохолдингів в Україні, який займає шосте місце за кількістю землі після "Кернел", Укр $А$ андФармінг, "Міронівський хлібопродукт", НААН України, "Агропросперіс". Аналіз звітності ТОВ "Астарта Прихоролля" показав, що навіть у такому великому та конкурентоспроможному підприємстві за роки пандемії спостерігається зменшення прибутку та скорочення чисельність працюючих [4].

Першим кроком у запропонованій стратегії $€$ комплекс превентивних заходів, які дозволяють мінімізувати наслідки кризи та їі вплив ще до початку. Так, станом на кінець 2018 року, досліджуване підприємство мало власний резервний фонд із загальною сумою понад 100 млн грн, та власне довготривале сховище насіння різних культур, загальною масою понад 5 тонн. Також на рівні вищого керівництва було ухвалено план дій на випадок непередбаченої ситуації, він складався з таких кроків:

1. Максимально повний аналіз кризової ситуації.

2. Визначення рівня та напряму загрози.

3. Визначення потреби у ресурсах та їх мобілізація.

4. Чітке розподілення ролей на підприємстві щодо ліквідації кризи.

5. Вивчення кризової ситуації та пошук шляхів її подолання.

6. Пристосування або подолання кризи. 
Таких заходів вживають переважно великі підприємства, оскільки середні та малі за розміром підприємства, як правило, не мають такого запасу міцності та чіткої програми антикризового менеджменту, і тому, у разі настання кризи, стають більш уразливими та потребують державної підтримки.

Аругим кроком є безпосереднє управління в умовах кризи. Цей крок передбачає скликання комісії з урегулювання ситуації, членами якої є керівники виробничих підрозділів, головні спеціалісти тваринництва та рослинництва, економісти тощо. Кожен 3 членів комісії має свою зону відповідальності у рамках антикризових заходів. Наприклад, головний зоотехнік підприємства має провести ряд заходів на молочнотоварній фермі, які дозволяють оптимізувати виробництво продукції в нових умовах, заготівлю та зберігання кормів та ін. В той самий час логістичний відділ має розв'язати питання з доставленням сировини та матеріалів в середині підприємства. Ауже важливим питанням як для рослинництва, так і для тваринництва є постачання палива, добрив, запасних частин для ремонту техніки, кормів, посівного матеріалу тощо. Головний економіст у цій ситуації має провести повний перерахунок усіх показників підприємства та визначити шляхи 3 найменшим ступенем ризику для господарства та скласти план щодо розвитку цього напряму. Тож, як показав досвід 2019-2021 років, ТОВ "Астарта Прихоролля" має чіткий план дії у кризовій ситуації за будь-яких умов.

Третім кроком є управління процесами виходу 3 кризи. На цьому етапі підприємство здійснює постійний моніторинг ринку та конкурентів, для планування своєї діяльності на тлі кризи. Очолює такий крок генеральний директор підприємства за допомоги головних спеціалістів у сфері економічної діяльності, тваринництва, рослинництва та служби логістики. Прикладом може слугувати те, що підприємство у 2021 році провело ряд заходів 3 відновлення контрактів на постачання продукції 3 підприємства, проведено аудит своїх ресурсів на всіх виробничих підрозділах та складено оперативний план дій по відновленню та розвитку підприємства на рівні країни.

Четвертим процесом антикризового управління є своєчасність управлінського впливу. Мається на увазі контроль усіх вищеописаних процесів, їх постійний моніторинг та усунення будь-яких факторів, що заважають виконанню плану. Аля цього на початку кожного тижня відбувається нарада 3 керівниками вищої ланки господарства, на якій обговорюються вироб- ничі питання та заслуховуються звіти про результати роботи антикризового менеджменту по кожному з напрямків. У процесі обговорення встановлюється коло питань, які потребують подальшого якіснішого вирішення. Після наради керівники вищої ланки проводять бесіди зі своїми підлеглими та розглядають питання по вирішенню конкретних завдань. Після їх виконання відбувається зворотний зв'язок i вже результати та проблеми, які було досягнуто протягом виробничого циклу, буде знову винесено на розгляд.

П'ятий крок - це стабілізація стану господарства. Оскільки підприємство вже здійснило ряд заходів антикризового менеджменту та основні наслідки кризи в минулому, варто задуматися над питанням відновлення діяльності на рівні докризового періоду. На момент 2021 року ТОВ "Астарта Прихоролля", проводиться ряд заходів по стабілізації та відновленню стану господарства. Так, у жовтні 2021 року, відбулася закупівля 40 голів високопродуктивних порід корів молочного напрямку, спеціально для цієї породи було відремонтовано приміщення для їх утримання та оснащено новітніми технологіями, зокрема системою клімат контролю, оскільки закуплена Голштинська порода $є$ вибагливою до навколишнього середовища. У рослинництві такими заходами є наповнення посівним матеріалом банку насіння. У листопаді 2021 року було завантажено 5 видів насіння різних культур загальною кількістю понад 7 тонн.

Останнім кроком є нівелювання відхилень від заданих меж. Оскільки ситуація вже стабілізувалася, то фінальним кроком є моніторинг відхилень господарства від заданих параметрів. Головною шкалою, за допомогою якої визначають ступінь показників відхилення є бізнесплан. Наприклад, за бізнес-планом на 2021 рік посівна площа кукурудзи мала складати 3550 га, але натомість виділена земельна площа становила на 500 га менше. Це різниця є доволі критичною, оскільки кукурудза є важливою кормовою рослиною для тваринництва. Нівелювання відхилення цього показника дозволяє оптимально прогнозувати виробництво проАукції тваринництва.

\section{ВИСНОВок}

Проаналізувавши процеси антикризового менеджменту на основі ТОВ "Астарта Прихороляя", можна зробити висновок, що наведені антикризові заходи є досить дієвими та відповідають сучасним стандартам менеджменту. Їх використання можливе на будь-якому сіль- 
ськогосподарському підприємстві та не потребує значних зусиль при впровадженні. Аля малих та середніх підприємств будуть доцільними такі державні заходи, як пільгове кредитування, податкові канікули, реалізація інфраструктурних проєктів, сприяння розвитку інновацій та інше.

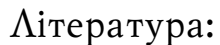

1. Батрак О.В., Тарасенко I.О. Теоретична конструкція антикризового управління підприємствами: дефініція, складники, етапи, принципи. Фахове наукове видання "Причорноморські економічні студії". Вип. 52-1. 2020. C. 111-115. URL: http://bses.in.ua/journals/2020/ 52_1_2020/19.pdf (Аата звернення 27.11.2021).

2. Вплив Covid-19 та карантинних обмежень на економіку України. 2020 https://www.kas.de/ documents/270026/8703904/Вплив+COVID$19+$ та+карантинних +обмежень +на+економік у + Ук раӥни. + Каб бін етне + д ослі Аження+ЦПА. + Аипень +2020 .pdf/ b7398098a $602-524 \mathrm{~d}-7 \mathrm{f} 88-6189058 \mathrm{f} 69 \mathrm{~d} 3$ ? version $=1.0 \&$ $\mathrm{t}=1597301028775$ (Аата звернення 01.12.2021).

3. Горобець I.I. Розвиток антикризового управління на підприємствах кондитерської галузі в умовах економічної нестабільності: дис. ... канд. екон. наук: 08.00.04. 3ВО Міжнародний університет економіки і права. Херсон. 2021. Одеська національна академія харчових технологій, Одеса, 2021. URL: https://www.onaft.edu.ua/download/dissertation/thesis/2021/ Disser-Gorobets.pdf (Аата звернення 25.11.2021).

4. Звіт про управління ТОВ "Астарта Прихоролля" за 2019-2020 роки. URL: https:// astartaholding.com/files/uploads/33d23a3823815472667551fec1c1d755.pdf (Аата звернення 12.12.2021).

5. Ковалевська А.В. Антикризове управління підприємством. Вісник Харківського нац. унт міськ. госп-ва ім. О. М. Бекетова. 2016. 140 с. URL: https://core.ac.uk/download/pdf/78067019.pdf (Аата звернення 14.12.2021).

6. Манжос С. Концептуальні підходи до трактування економічної сутності антикризового менеджменту. Галицький економічний вісник. 2013. № 3 (42). С. 23-32. URL: https:// galicianvisnyk.tntu.edu.ua/pdf/42/299.pdf (Дата звернення 14.12.2021).

7. Офіційний сайт Аержавної служби статистики України. URL: http://www.ukrstat.gov.ua/ (Аата звернення 16.12.2021).

8. Програма стимулювання економіки для подолання наслідків пандемії Covid-19. "Економічне відновлення". Інформаційно-аналітична довідка. 2020. URL: https://www.kmu.gov.ua/
storage/app/sites/1/18\%20-\%20Department/ Prezentacii/Programa\%20Ekonomichne\%20stymyluvannia/a nalitichni-materiali-doprogrami-stimulyuvannya-1.pdf (Аата звернення 20.12.2021).

9. Прокопишин О.С. Система антикризового управління як підгрунтя попередження кризових явищ на підприємствах. Інвестиції: практика та досвід. № 9. 2021. С. 140-145. URL: http://www.investplan.com.ua/pdf/9_2021/8.pdf (Аата звернення 15.12.2021).

10. Самойленко В.В. Удосконалення методів антикризового менеджменту в умовах сучасних інформаційних технологій. Електронне наукове фахове видання "Ефективна економіка". № 4. 2020. URL: http://www.economy.nayka.com.ua/pdf/4_2020/105.pdf (Аата звернення 10.12.2021).

11. Стешенко O.А., Масалигіна B.В. Антикризове управління в умовах пандемії. Вісник економіки транспорту і промисловості. 2020. № 70-71. C. 75-82 http://btie.kart.edu.ua/article/ download/222131/222306 (Аата звернення 18.12.2021).

12. Тулуш М.О., Радченко О.А. Аержавна підтримка фермерських та селянських господарств для подолання наслідків пандемії Covid-19. Наука оптимальних податкових рішень. HHI фіскальної політики. 2. URL: https://www.ndifp.com/1483/ (Аата звернення 03.12.2021).

13. Циган Р.М. Негативні чинники впливу кризи, спричиненою пандемією Covid-19, на малий і середній бізнес. Електронне наукове фахове видання "Ефективна економіка". № 1. 2021. URL: http://www.economy.nayka.com.ua/ pdf/1_2021/95.pdf (Аата звернення 22.12.2021).

14. Miroshnychenko O. Stabilization of the national currency rate in ensuring anti-crisis development and economic security of Ukraine: Anti-Crisis Management: State, Region, Enterprise. Collective monograph. Kaunas, Lithuania: "Baltija Publishing", 2020. Pp. 45-62. URL: http:/ /www.baltijapublishing.lv/omp/index.php/bp/ catalog/view/93/2334/5029-1 (Accessed 25 Des).

15. Ker A.P., Biden S. Risk management in Canada's agricultural sector in light of COVID-19: Considerations one year later. Canadian Journal of Agricultural Economics. 2021. Issue 69 (2). Pp. 299-306. URL:https://www.ncbi.nlm.nih.gov/ pmc/articles/PMC8207034/ (Accessed 12 Des).

16. Shihua Zeng. Agricultural Supply Chain Risk Management in the Post-epidemic Era Web of Conferences 257. 2021. URL: https://www.e3sconferences.org/articles/e3sconf/pdf/2021/33/ e3sconf_aesee2021_02090.pdf (Accessed 4 Des). 
References:

1. Batrak, O.V. and Taracenko, I.O. (2020), "Theoretical construction of crisis management of enterprises: definition, components, stages, principles", Prychornomors'ki economichni studii, vol. 52-1, pp. 111-115, available at: http:// bses.in.ua/journals/2020/52_1_2020/19.pdf (Accessed 27 November 2021).

2. Center of powerful research (2020) "The impact of Covid-19 and quarantine restrictions on the economy of Ukraine", available at: https:// www.kas.de/documents/270026/8703904/ Вплив+COVID-19+та+карантинних+обмежень + на + економіку + України. + Кабінетне+дослідження ЦЦА. $+\Lambda$ ипень $+2020 . p d f /$ b7 398098-a602-524d-7f88-6189058f69d3?version $=1.0 \& \mathrm{t}=1597301028775$ (Accessed $1 \mathrm{De}$ sember 2021).

3. Horobets', I.I. (2021), "Development of anticrisis management at the confectionery industry in conditions of economic instability", Abstract of Ph.D. dissertation, Economics and management of enterprises by type of activity, International University of Economics and Law, Kherson, Ukraine, Odessa national Academy of Food Technologies, Odessa. Ukraine, available at: https://www.onaft.edu.ua/download/ dissertation/thesis/2021/Disser-Gorobets.pdf (Accessed 25 November 2021).

4. Astarta Holding (2021), "Management report of a limited liability company Astarta Prykhorollya for 2019-2020", available at: https:/ / a startaholding.com/files/uploads/ 33d23a3823815472667551fec1c1d755.pdf (Accessed 12 Des).

5. Kovalevs'ka, A.V.(2016), "Anti-crisis management of the enterprise", Visnyk Kharkivs'kogo natsional'noho universytetu mis'koho hospodsrstva im. O.M. Beketova, Available at: https:// core.ac.uk/download/pdf/78067019.pdf (Accessed 14 Desember 2021).

6. Manzhos, M. (2013), "Conceptual approaches to the interpretetion of the economic essence of crisis management", Halits'kyj ekonomichnyj visnyk, vol. 3 (42), pp. 23-32, available at:https:/ /galicianvisnyk.tntu.edu.ua/pdf/42/299.pdf (Accessed 14 Desember 2021).

7. State Statistics Service of Ukraine (2021), "The main indicators of agricultural enterprises for 1996-2020", available at: http://www.ukrstat.gov.ua/ (Accessed 16 Desember 2021).

8. Cabinet of Ministers of Ukraine (2020), "Economic stimulus program to overcome the effects of the pandemic Covid-19", Ekonomic recovery. Information-analytical reference, available at: https://www.kmu.gov.ua/storage/
app/sites/1/18\%20-\%20Department/Prezentacii/ Programa\%20Ekonomichne\%20stymyluvannia/ analitichni-materiali-do-programi-stimulyuvannya-1.pdf (Accessed 20 Desember 2021).

9. Prokopyshyn, O.S. (2021), "Anti-crisis management system as a basic for ctisis prevention at the enterprise", Investytsii: praktyka i dosvid, vol. 9, pp. 140-145, available at: http://www.investplan.com.ua/pdf/9_2021/8.pdf (Accessed 15 Destmber 2021).

10. Samoylenko, V.V. (2020), "Improvement of anti-crisis management methods in the conditions of modern information technologies", Efektyvna ekonomika, [Online], vol. 4, available at: http:// www.economy.nayka.com.ua/pdf/4_2020/ 105.pdf (Accessed 10 Desember 2021).

11. Steshenko, O.D and Masalihina, V.V. (2020), "Crisis management in pandemic", Visnyk ekonomiky transportu i promyslovosti, vol. 70-71, pp. 75-82, available at: http://btie.kart.edu.ua/ article/download/222131/222306 (Accessed 18 Desember 2021).

12. Tulush, L.O. and Radchenko, O.D. (2020), "State support of farms and peasant farms to overcome the effects of the pandemic Covid-19", Nauka optymal'nykh podatkovykh rishen', NNI fiskal'noyi polityky, available at: https:// www.ndifp.com/1483/ (Accessed 3 Desember 2021).

13. Tsyhan, R.M. (2021), "Negative factors of the pandemic crisis Covid-19 on small and mediumsized businesses", Efektyvna ekonomika, vol. 1, available at: http://www.economy.nayka.com.ua/ pdf/1_2021/95.pdf (Accessed 22 Desember 2021).

14. Miroshnychenko, O. (2020), Stabilization of the national currency rate in ensuring anti-crisis development and economic security of Ukraine: Anti-Crisis Management: State, Region, Enterprise, Baltija Publishing, Kaunas, Lithuania, pp. 45-62, available at: http://www.baltijapublishing.lv/omp/index.php/bp/catalog/view/93/ 2334/5029-1 (Accessed 25 Desember 2021).

15. Ker, A.P. and Biden, S. (2021), "Risk management in Canada's agricultural sector in light of COVID-19: Considerations one year later", Canadian Journal of Agricultural Economics, vol. 69 (2), pp. 299-306, available at: https://www.ncbi.nlm.nih.gov/pmc/articles/PMC8207034/ (Accessed 12 Desember 2021).

16. Shihua, Zeng (2021), "Agricultural Supply Chain Risk Management in the Post-epidemic Era", Web of Conferences 257, available at: https:/ /www.e3s-conferences.org/articles/e3sconf/pdf/ 2021/33/e3sconf_aesee2021_02090.pdf (Accessed 4 Desember 2021).

Стаття надійшла до редакиї 31.12.2021 p. 
УAK 631.11.005 (477)

\author{
А. О. Єфімцева, \\ старший викладач, Київський кооперативний інститут бізнесу і права \\ ORCID ID: 0000-0002-9519-3647
}

\title{
ВИЗНАЧЕННЯ АОЦІАЬНОСТІ ПРИАБАННЯ СІАЬСЬКОГОСПОААРСЬКИМИ ВИРОБНИКАМИ ОСНОВНИХ ВИАІВ ТЕХНІЧНИХ ЗАСОБІВ
}

\author{
L. Yefimtseva, \\ Senior Lecturer, Kyiv Cooperative Institute of business and law
}

\author{
DETERMINING THE FEASIBILITY OF PURCHASING BASIC TYPES
}

OF TECHNICAL MEANS BY AGRICULTURAL PRODUCERS

У статті розроблено модель визначення доцільності придбання сільськогосподарськими виробниками основних видів технічних засобів. Застосування розробленої моделі Аасть можливість сільгоспвиробникам розрахувати Аоцільність придбання технічних засобів у залежності від площі сільськогосподарських угідь, у результаті чого аграрії зможуть обрати економічно доцільніший варіант між придбанням технічних засобів або використання у виробничій діяльності агротехнологічних послуг сторонніх організацій.

Встановлено граничну межу площі сільськогосподарських угідь, при якій доцільно мати в наявності власні технічні засоби та площу сільгоспугідь, при якій ефективніше використовувати у виробничій діяльності послуги сторонніх організацій. Мати весь комплекс власних технічних засобів та не використовувати у виробничій діяльності агротехнологічні послуги сторонніх організацій доцільно сільськогосподарським виробникам, які мають площу сільгоспугідь віА 400 гектар. Аля аграріїв із площею сільгоспугідь до 400 гектар доцільність придбання технічних засобів залежить від виду агротехнологічних послуг, яких потребує виробничий процес вирощування продукції рослинництва:

- при виконанні робіт з оранки та культивації аграріям із плещею сільгоспугідь до 200 гектар доцільно використовувати у виробничій діяльності агротехнологічні послуги сторонніх організацій;

- Аля виконання робіт з посіву, внесення добрив та захисту сільськогосподарських культур, враховуючи можливість виконання трьох видів польових робіт, нижчу вартість трактора Аля виконання вказаних робіт та причіпного обладнання до нього, високу продуктивність та в рази нижчі витрати палива, доцільно мати в наявності власні технічні засоби та не застосовувати у виробничій Аіяльності агротехнологічні послуги Аля виконання вказаних робіт сільськогосподарським виробникам із площею сільгоспугідь від 50 гектар;

- Аля виконання робіт зі збору урожаю доцільно мати власний комбайн сільськогосподарським виробникам із площею сільгоспугідь від 400 гектар.

Використання розробленої моделі визначення витрат на придбання та експлуатацію технічних засобів в першу чергу сприятиме розвитку виробничої діяльності аграріїв із площею сільськогосподарських угідь до 500 гектар, оскільки саме вказана група сільгоспвиробників фінансово не спроможна забезпечити виробничий процес основними виАами технічних засобів.

Аостатнє, що відповідає сучасним вимогам, забезпечення виробничого процесу агротехнологічними послугами та власними технічними засобами сільськогосподарських виробників (як представників агробізнесу, так і особистих селянських домогосподарств) сприятиме зростанню іх фінансово-економічних показників та рівню конкурентоспроможності. 
The article develops a model for determining the feasibility of agricultural producers to purchase the main types of technical means. The application of the developed model will allow farmers to calculate the feasibility of purchasing technical means depending on the area of agricultural land, as a result, farmers will be able to choose the most economically viable option between the purchase of technical means or the use of agro-technological services of third-party organizations in production activities.

The maximum limit of the area of agricultural lands at which it is expedient to have own technical means and the area of agricultural lands at which it is more effective to use services of third-party organizations in production activity is established. It is expedient for agricultural producers, who have an area of agricultural land of 400 hectares, to have the whole complex of their own technical means and not to use agro-technological services of third-party organizations in their production activities.

For farmers with an area of agricultural land up to 400 hectares, the expediency of purchasing technical equipment depends on the type of agro-technological services required by the production process of growing crop products:

- when performing plowing and cultivation works, farmers with an area of agricultural land up to 200 hectares should use agro-technological services of third-party organizations in their production activities;

- for sowing, fertilizing and crop protection, taking into account the possibility of three types of field work, the lower cost of the tractor to perform these works and the trailer equipment to it, high productivity and many times lower fuel consumption, it is advisable to have their own technical means and not to use in production agro-technological services to perform these works to agricultural producers with an area of agricultural land from 50 hectares;

- to harvest work, it is advisable to have your own combine harvester for farmers with an area of agricultural land of $\mathbf{4 0 0}$ hectares.

The use of the developed model for determining the costs of acquisition and operation of technical means will primarily contribute to the development of production activities of farmers with an area of agricultural land up to 500 hectares, as this group of agricultural producers is not financially able to provide the production process with the main types of technical means.

Enough that, meeting modern requirements, providing the production process with agro-technological services and own technical means of agricultural producers (both representatives of agribusiness and individual peasant households) will help increase their financial and economic performance and level of competitiveness.

Ключові слова: витрати, собівартість, площа сільськогосподарських угідь, гранична межа, дочільність, технічні засоби, агротехнологічні послуги.

Key words: costs, cost, area of agricultural lands, limit, expediency, technical means, agrotechnological services.

\section{ПОСТАНОВКА ПРОБЛЕМИ У ЗАГАЛЬНОМУ ВИГЛЯДІ ТА ІІЇ ЗВ'ЯЗОК ІЗ ВАЖЛИВИМИ НАУКОВИМИ ЧИ ПРАКТИЧНИМИ ЗАВДАННЯМИ}

Одним із важливих чинників стійкого розвитку сільського господарства є ступінь матеріально-технічного забезпечення виробничого процесу основними і оборотними засобами (сільськогосподарською технікою, виробничими потужностями, насінням, засобами хімізації, пально-мастильними матеріалами, енергоносіями тощо). В аграрному секторі значимими є своєчасне виконання і дотримання послідовності основних технологічних операцій, які передбачені умовами аграрного виробництва. Це потребує наявності основних виробничих засобів у необхідній кількості та відповідної якості, що забезпечують своєчасність і комплексність операційного процесу сільськогосподарського виробництва. В свою чергу для багатьох вітчизняних аграріїв, передусім середніх та малих форм господарювання, залишається невирішеною проблема кількісного і якісного забезпечення основними видами техніки. Більшість таких господарств фінансово неспроможні сформувати комплексний машинно-тракторний парк, який відповідає сучасному рівню технічного забезпечення в передових країнах світу. Аля ефективної 
діяльності сільськогосподарських виробників 3 площею сільгоспугідь до 500 гектар у процесі вирощування продукцї̈ рослинництва суттєвим фактором виступає забезпечення виробничого процесу сучасними високоефективними технічними засобами. ОАнак вказаній групі сільгоспвиробників необхідно обрати економічно доцільніший варіант між використання у виробничому процесі власних технічних засобів або використання агротехнологічних послуг сторонніх організацій: "...ефективність інвестицій...формується, головним чином, на етапі вибору інвестиційних варіантів і рішень..." [1, с. 7]. Тому розробка моделі, якою можуть скористатися сільськогосподарські виробники із площею сільгоспугідь до 500 гектар при вирішенні питання доцільності вкладення коштів в придбання сільськогосподарської техніки та обладнання виступає важливим чинником для їх ефективного розвитку. Окрім вказаного, на сучасному етапі розвитку аграрного сектору, враховуючи багатоукладність аграрної економіки, визначення межі площі сільськогосподарських угідь, коли використання у виробничому процесі власних технічних засобів економічно доцільніше порівняно 3 використанням агротехнологічних послуг сторонніх організацій та навпаки, встановлення розміру площі сільгоспугідь, при якій більш доцільно використовувати у виробничій діяльності агротехнологічні послуги сторонніх організацій, являється нагальним.

\section{АНАЛІЗ ОСТАННІХ ДОСЛІДЖЕНЬ І ПУБЛІКАЦІЙ, В ЯКИХ ЗАПОЧАТКОВАНО РОЗВ'ЯЗАННЯ ДАНОЇ ПРОБЛЕМИ І НА ЯКІ СПИРАЄТЬСЯ АВТОР, ВИДІЛЕННЯ НЕ ВИРІШЕНИХ РАНІШЕ ЧАСТИН ЗАГАЛЬНОЇ ПРОБЛЕМИ, КОТРИМ ПРИСВЯЧУЄТЬСЯ ОЗНАЧЕНА СТАТTЯ}

Внесок у розробку визначення суми необхідних вкладень на придбання технічних засобів та розрахунку витрат на виконання основних видів агротехнологічних робіт зробили вчені Кропивко М.Ф., Кісіль М.І., Целюк О.О., Шкільов О.В., Мельник С.І., Пивовар В.С., Моссаковський В.Б., Костякова А.А., Кононенко Т.В. та інші науковці.

Зокрема, Кропивко М.Ф. було запропоновано модель визначення вартості (маркетингового тарифу) окремих машин та машин в агрегаті з іншими технічними засобами, оскільки агротехнологічні роботи можуть виконувати- ся як окремою самохідною машиною, так і в агрегаті з іншими технічними засобами [2, с. 8]. Науковець $\Lambda$ елюк О.О. представив модель визначення вартості агротехнологічних робіт, визначення в якій схоже на представлену передню модель, оскільки за основу до розрахунку береться також вартість технічного засобу та відсотки усіх видів витрат [3].

Групою авторів під керівництвом Шкільова O.B. [4] було запропоновано визначення суми необхідних вкладень на придбання технічних засобів. Кропивко М.Ф., Кісіль М.І. було розглянуто теоретичні засади і методичні підходи до формування стратегії управління ефективністю інвестицій фермерського господарства [1].

Значний вклад у визначення витрат палива і норм продуктивності для сільськогосподарської техніки, яка використовується для проведення кваліфікаційної експертизи сортів рослин у філіях кваліфікаційної експертизи сортів рослин було розроблено Мельник С.I., Пивовар В.С. [5]. Групою науковців у складі Моссаковського В.Б., Костякова А.А. та Кононенко Т.В. було розглянуто особливості розрахунку точки беззбитковості в аграрній сфері [6].

Однак, незважаючи на вагомий вклад науковців у визначенні витрат на придбання технічних засобів та визначенні вартості виконання основних видів польових робіт, питання встановлення граничної межі площі сільськогосподарських угідь, при якій доцільно мати в наявності власні технічні засоби та площі сільгоспугідь, при якій ефективніше використовувати у виробничій діяльності послуги сторонніх організацій, залишилося поза увагою науковців.

\section{ФОРМУЛЮВАННЯ ЦІЛЕЙ CTATTI}

Враховуючи значимість питання прийняття рішення стосовно доцільності придбання технічних засобів для здійснення основних видів польових робіт, метою статті було виконання наступних завдань:

по-перше, визначення граничного рівня площі, при якій сільськогосподарському виробнику доцільно придбати технічні засоби та навпаки, площі, при якій доцільно використовувати агротехнологічні послуги сторонніх організацій;

по-друге, розробка моделі, якою може скористатися сільськогосподарський виробник при вирішенні питання доцільності вкладення коштів в придбання сільськогосподарської техніки та обладнання. 
Таблиця 1. Групування підприємств за розмірами зібраної площі сільськогосподарських культур у 2020 році

\begin{tabular}{|c|c|c|c|c|c|c|c|c|c|c|}
\hline \multirow{3}{*}{$\begin{array}{c}\text { Підприємства, } \\
\text { що мали } \\
\text { сільськогос- } \\
\text { подарські угіддя, } \\
\text { у тому числі } \\
\text { площею, га }\end{array}$} & \multicolumn{10}{|c|}{ Культури, у тому числі: } \\
\hline & \multicolumn{2}{|c|}{$\begin{array}{c}\text { зернові (пшениця, } \\
\text { ячмінь) }\end{array}$} & \multicolumn{2}{|c|}{ кукурудза на зерно } & \multicolumn{2}{|c|}{$\begin{array}{c}\text { цукровий буряк } \\
\text { фабричний }\end{array}$} & \multicolumn{2}{|c|}{$\cos$} & \multicolumn{2}{|c|}{ соняшник } \\
\hline & $\begin{array}{c}\text { підпри- } \\
\text { ємств, од. }\end{array}$ & $\begin{array}{c}\text { частка, } \\
\text { \% }\end{array}$ & $\begin{array}{l}\text { підпри- } \\
\text { ємств, од. }\end{array}$ & $\begin{array}{c}\text { частка, } \\
\%\end{array}$ & $\begin{array}{c}\text { підпри- } \\
\text { ємств, од. }\end{array}$ & $\begin{array}{c}\text { частка, } \\
\%\end{array}$ & $\begin{array}{c}\text { підпри- } \\
\text { ємств, од. }\end{array}$ & $\begin{array}{c}\text { частка, } \\
\text { \% }\end{array}$ & $\begin{array}{c}\text { підпри- } \\
\text { ємств, од. }\end{array}$ & $\begin{array}{c}\text { частка, } \\
\text { \% }\end{array}$ \\
\hline $\begin{array}{l}\text { Всього } \\
\text { підприємств }\end{array}$ & 37310 & 100,0 & 15115 & 100,0 & 506 & 100,0 & 100,00 & 100,00 & 21856 & 100,00 \\
\hline у тому числі: & & & & & & & & & & \\
\hline до 100,0 & 25574 & 68,54 & 8988 & 59,4 & 253 & 50,0 & 73,60 & 73,60 & 12692 & 58,10 \\
\hline $100,1-200,0$ & 4420 & 11,85 & 2049 & 13,6 & 86 & 17,0 & 12,30 & 12,30 & 2894 & 13,20 \\
\hline $200,1-500,0$ & 4307 & 11,54 & 2155 & 14,3 & 80 & 15,8 & 9,10 & 9,10 & 3424 & 15,70 \\
\hline $500,1-1000,0$ & 1874 & 5,02 & 984 & 6,5 & 31 & 6,1 & 2,80 & 2,80 & 1704 & 7,80 \\
\hline Понад 1000,0 & 3052 & 11,93 & 939 & 6,21 & 56 & 11,1 & 2,26 & 2,26 & 1142 & 5,23 \\
\hline
\end{tabular}

Ажерело: складено за статистичними даними [7].

\section{ВИКЛАД ОСНОВНОГО МАТЕРІАЛУ ДОСЛІДЖЕННЯ 3 ПОВНИМ ОБГРУНТУВАННЯМ ОТРИМАНИХ НАУКОВИХ РЕЗУЛЬТАТІВ}

На сучасному етапі розвитку аграрного сектору, враховуючи багатоукладність аграрної економіки, визначення межі площі сільськогосподарських угідь, коли використання у виробничому процесі власних технічних засобів економічно доцільніше порівняно з використанням агротехнологічних послуг сторонніх організацій та навпаки, встановлення розміру площі сільгоспугідь, при якій більш доцільно використовувати у виробничій діяльності агротехнологічні послуги сторонніх організацій, являється нагальним. Враховуючи значимість питання прийняття рішення стосовно доцільності придбання технічних засобів для виконання основних видів агротехнологічних робіт, у дослідженні було поставлено дві задачі:

по-перше, визначення граничного рівня площі, при якій сільськогосподарському виробнику доцільно придбати технічні засоби та навпаки, площі, при якій доцільно використовувати агротехнологічні послуги сторонніх організацій;

по-друге, розробка моделі, якою може скористатися сільськогосподарський виробник при вирішенні питання доцільності вкладення коштів в придбання сільськогосподарської техніки та обладнання.

Аля здійснення поставленої задачі нами було визначено доцільність придбання технічних засобів для сільськогосподарського виробника із площею угідь 200 гектар, який спеціалізується на вирощуванні пшениці та ячменю. Вибір спеціалізації можна пояснити результатами групування підприємств за розмірами зібраної площі сільськогосподарських культур у 2020 році, які показали, що саме у аграріїв із площею сільськогосподарських угідь до 100,0 гектар найбільша частка 3 усіх сільськогосподарських виробників складали сільгоспугіддя по зерновим культурам (пшениця, ячмінь), а саме 68,54\%. Окрім цього, у аграріїв із площею сільгоспугідь від 100,0 до 500,0 частка зібраної площі по зерновим культурам складала $11,8-11,54 \%$ (табл. 1$)$.

На початку дослідження при встановленні доцільності придбання технічних засобів було розраховано потребу у аграріїв в технічних засобах. Стосовно виду технічних засобів та агрегатів для виконання основних видів польових робіт, їх продуктивність та витрати палива, нами було використано науково-методичні рекомендації Українського інституту експертизи сортів рослин [5], згідно з якими для виконання робіт з оранки та культивації рекомендується застосовувати трактор "ХТ3-17021" в агрегаті 3 плугом ПАН-5-35, для виконання робіт $з$ посіву, внесення добрив та захисту сільгоспкультур рекомендовано застосовувати трактор МТ3-920 з агрегатом з МВА-1000 для виконання робіт по внесенню добрив, агрегатом ОП-800 для виконання робіт 3 посіву та причіпним обладнанням СПУ-6А для виконання робіт з хімічного захисту рослин [5, с. 8].

Визначення потреби в технічних засобах у розрахунку на 200 гектар обробки площі сільськогосподарських угідь здійснювалося за формулою 1:

$\mathrm{P}$ агр. $=\mathrm{O} / \mathrm{H} * \mathrm{~K} * \mathrm{~T}$

де $\mathrm{P}$ агр. - кількість агрегатів, $\mathrm{O}$ - обсяг робіт, $\mathrm{H}$ - змінна норма виробітку, $\mathrm{K}$ - коефіцієнт змінності (його значення $1,5-2$ ), Тстроки виконання робіт.

Розрахунок показав, що для виконання робіт з оранки та культивації сільгоспвиробнику для виконання вказаних робіт необхідно один трактор ХТ3-17021 та для виконання робіт хімічного захисту рослин становить, по- 
Таблиця 2. Технічні характеристики технічних засобів для виконання основних видів польових робіт для сільгоспвиробника із площею сільгоспугідь 200 гектар, спеціалізація вирощування зернових культур (пшениця, ячмінь)

\begin{tabular}{|l|l|l|l|l|l|l|l|l|}
\hline \multicolumn{1}{|c|}{ Вид робіт } & $\begin{array}{c}\text { Марка } \\
\text { технічних } \\
\text { засобів }\end{array}$ & Агрегат & $\begin{array}{c}\text { Вартість } \\
\text { технічного } \\
\text { засобу, грн }\end{array}$ & $\begin{array}{c}\text { Вартість } \\
\text { агрегату, } \\
\text { грн }\end{array}$ & $\begin{array}{c}\text { Продук- } \\
\text { тивність за } \\
\text { зміну, га }\end{array}$ & $\begin{array}{c}\text { Продук- } \\
\text { тивність за } \\
\text { годину, га }\end{array}$ & $\begin{array}{c}\text { Витрати } \\
\text { палива, } \\
\text { л/га }\end{array}$ & $\begin{array}{c}\text { Потреба, } \\
\text { одиниць }\end{array}$ \\
\hline Оранка & $\begin{array}{l}\text { Трактор } \\
\text { «Т3-17021» }\end{array}$ & $\begin{array}{l}\text { Плуг } \\
\text { ПЛН-5-35 }\end{array}$ & 1471000,0 & 53000,0 & 8,1 & 1,16 & 19,5 & 0,9 \\
\hline Культивація & $\begin{array}{l}\text { Трактор } \\
\text { «Т3-17021» }\end{array}$ & АПГ-4,5 & 1471000,0 & 35000,0 & 20,5 & 2,93 & 7,9 & 0,3 \\
\hline $\begin{array}{l}\text { Внесення } \\
\text { добрив }\end{array}$ & $\begin{array}{l}\text { Трактор } \\
\text { МТЗ-920 }\end{array}$ & МВД-1000 & 510000,0 & 37000,0 & 44,2 & 6,31 & 1,5 & 0,2 \\
\hline $\begin{array}{l}\text { Хімічний } \\
\text { захист }\end{array}$ & $\begin{array}{l}\text { Трактор } \\
\text { МТЗ-920 }\end{array}$ & ОП-800 & 510000,0 & 27500,0 & 29,3 & 4,88 & 1,25 & 0,3 \\
\hline Посів & МТЗ-920 & СПУ-6Д & 510000,0 & 363804,0 & 21,6 & 6,3 & 2,7 & 0,2 \\
\hline Збір урожаю & Полісся & - & 2528300,0 & - & 22,0 & 3,14 & 6,6 & 0,3 \\
\hline
\end{tabular}

* Тривалість зміни становить 7 годин, для виконання робіт з хімічного захисту рослин тривалість зміні становить 6 годин.

Ажерело: складено та розраховано автором за даними Українського інституту експертизи сортів рослин [5].

сіву сільгоспкультур та внесення добрив необхідно також один трактор МТ3-920 (табл. 2).

Однак визначення потреби в технічних засобах містить обмежену інформацію, яка не характеризує сільгоспвиробнику економічної доцільності придбання технічного засобу, а саме суми вкладень на придбання трактору, комбайну та необхідних агрегатів, собівартості виконання агротехнологічних робіт.

Визначення доцільності придбання технічних засобів та граничного рівня площі, при якій сільськогосподарському виробнику доцільно придбати технічні засоби та навпаки, площі, при якій доцільно використовувати агротехнологічні послуги сторонніх організацій, пропонуємо здійснювати в наступній послідовності:

по-перше, визначити суму необхідних вкладень на 1 гектар сільгоспугідь ( $\left.\mathrm{B}_{1 \text { га }}\right)$;

по-друге, розрахувати собівартість виконання 1 гектару робіт $\left(\mathrm{C}_{1 \text { га }}\right)$;

по-третє, розрахувати загальну суму витрат у рік для сільгоспвиробника 3 врахуванням площі сільгоспугідь $\left(\mathrm{B}_{\mathrm{S}^{\mathrm{pi \kappa}}}\right)$;

по-четверте, порівняти загальні витрати в рік у випадку застосування власних технічних засобів із витратами в рік на оплату технологічних послуг сторонніх організацій для вибору економічно доцільного варіанту.

Оскільки розрахунок суми необхідних вкладень уже було розроблено [4, с. 22], пропонуємо скористатися розробками науковців із незначними змінами методик розрахунків. Автором було запропоновано розраховувати капіталовкладення на 1 гектар за формулою 2:

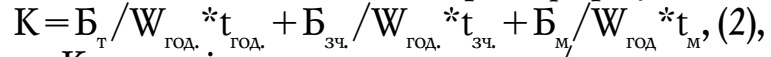

де $\mathrm{K}$ - капіталовкладення, грн/га;

$\mathrm{b}_{\mathrm{T}}, \mathrm{b}_{\text {зч }}, \mathrm{b}_{\mathrm{m}}$ - балансова вартість тягових, самохідних і сільгоспмашин для використання операцій, грн;

$$
\mathrm{W}_{\text {год }} \text { - годинна продуктивність, га; }
$$

$\mathrm{t}_{\mathrm{T}}, \mathrm{t}_{\text {зч }}, \mathrm{t}_{\mathrm{m}}-$ річне завантаження сільськогосподарських машин, год.

Враховуючи, що трактор може виконувати декілька операцій з різним причіпним обладнанням, пропонуємо ввести в розрахунок капітальних вкладень показник n, а саме кількість здійснюваних робіт вказаним трактором. Також, враховуючи, що середній термін експлуатації технічних засобів складає 10 років, при визначенні суми вкладень на один гектар вважаємо доцільним використати показник термін експлуатації технічних засобів (TE). У результаті допрацьована формула визначення вкладень на 1 гектар робіт буде наступна:

$\mathrm{B}_{1 \text { га }}=\left(((\mathrm{BT} / \mathrm{n}+\mathrm{BA}) / \mathrm{TE}) /\left(\Pi_{1 \text { год. }} * \mathrm{~T}_{\text {річна,год }}\right)\right)(3)$, де $\mathrm{B}_{1 \text { га }}$ - вкладення на 1 гектар;

ВТ - балансова вартість технічних засобів, грн;

$\mathrm{n}$ - кількість видів робіт, які виконуються технічним засобом;

ВА - вартість агрегату для виконання робіт;

$\mathrm{TE}$ - термін експлуатації технічних засобів, років;

$\Pi_{1 \text { год }}-$ продуктивність технічного засобу за годину роботи, га;

$\mathrm{T}_{\text {річна }}$ - річне завантаження технічного засобу (за сезон), год.

Застосувавши вказану формулу при розрахунках для сільськогосподарського виробника із площею угідь 200 гектар сума вкладень на 1 гектар власними технічними засобами для основних видів робіт складатиме 294,4 грн/гектар по виконанню робіт з оранки, 44,9 грн/гектар 3 культивації, 2,6 грн/гектар по внесенню добрив, 28,0 грн/гектар 3 посіву, 4,1 грн/гектар по хімічному захисту сільгоспкультур та 116,1 грн/ гектар по збору урожаю.

$\mathrm{B}_{1 \text { га.оранка }}=(((1471000,0 / 2+51000,0) / 10) /$ $(1,2 * 172,8))=294,4$ грн. 
Аля визначення завантаженості за сезон $\left(\mathrm{T}_{\text {річна,год }}\right)$ необхідно площу сільгоспугідь (S) розділити на продуктивність за годину роботи трактора разом з відповідним агрегатом:

$\mathrm{T}_{\text {річна,год }}=\mathrm{S} / \Pi_{1 \text { го }}=200,0 / 1,2=172,8$ год $/ \mathrm{piк}$

Аля інших видів робіт розрахунки будуть такими:

$\mathrm{B}_{1 \text { га.куаьт }}=(((1471000,0 / 2+35000,0) / 10) /$ $(2,9 * 68,3))=44,9$ грн $/$ га.

$\mathrm{T}_{\text {річн. культ. }}=\mathrm{S} / \Pi 1_{\text {год }}=200,0 / 2,9=68,3$ гоА $/$ piк.

$\mathrm{B}_{1 \text { річн. кульст. }}=(((510000,0 / 3+37000,0) / 10) /$

$(6,3 * 31,7))=2,6$ грн/ га.

$\mathrm{T}_{\text {рінна, год }}=\mathrm{S} / \Pi_{1 \text { гол }}=200,0 / 6,3=31,7$ год $/$ рік.

$\mathrm{B}_{1 \text { га.хім.зах. }}^{\text {річна год }}=(((510000,0 / 3+27500,0) / 10) /$ $(4,9 * 40,96))=4,1$ грн/га.

$\mathrm{T}_{\text {річна,гоА }}=\mathrm{S} / \Pi_{1 \text { гол }}=200,0 / 4,9=41,0$ гоА $/$ рік

$\mathrm{B}_{1 \text { гапосів. }}^{\text {річнагод }}=(((510000,0 / 3+363804,0) / 10) /$

$(3,1 * 64,8))=28,0$ грн/га.

$\mathrm{T}_{\text {річна,год }}=\mathrm{S} / \Pi_{1 \text { год. }}=200,0 / 3,1=64,8$ год $/$ рік.

При розрахунку суми вкладень на гектар для виконання робіт зі збору урожаю суму вартості технічних засобів не ділили на кількість робіт, оскільки вказаним комбайном може виконуватися збір усіх зернових культур, тому розрахунки матимуть такий вигляд:

$\mathrm{B}_{1 \text { га збір хрожаю }}=\left((\mathrm{BT} / \mathrm{TE}) /\left(\Pi_{1 \text { год }} * \mathrm{~T}_{\text {річна }}\right)\right)=$ $((2528300,0) / 10) /(3,3 * 60,6))=116,1$ грн $/$ га.

$\mathrm{T}_{\text {ріна аод }}=\mathrm{S} / \Pi_{1 \text { год }}=200,0 / 3,3=60,6$ год $/$ рік

Наступним етапом розрахунків для визначення загальної суми витрат в рік для сільгоспвиробника з врахуванням площі сільгоспугідь $\left(\mathrm{B}_{\mathrm{S}}\right.$ рік) буде розрахунок собівартості гектару виконання агротехнологічних робіт по формулі:

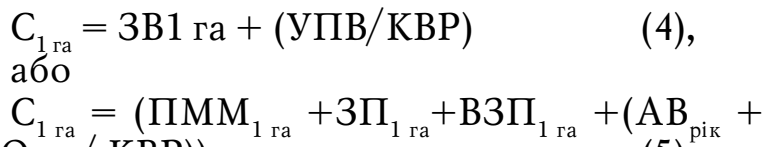
$\left.\left.\mathrm{BTO}_{\text {pir }}, / \mathrm{KBP}\right)\right)$

де $3 \mathrm{~B}_{1 \text { га }}-3$ мінні витрати на обробку 1 гектару сільгоспугідь, грн/га;

УПВ - умовно-постійні витрати на обробку 1 гектару сільгоспугідь, грн/га;

КВP - загальна кількість виконаних робіт за сезон, гектар;

$\Pi_{1 \text { га }}$ - вартість паливо-мастильних матеріалів на виконання 1 гектару робіт, грн/га;

$\mathrm{BTO}_{\text {рік }}$ - витрати на ремонт та сервісне обслуговування на рік, грн;

$3 \Pi_{1 \text { га }}$ - заробітна плата механізатора для виконання 1 гектару робіт, грн/га;

В3П ${ }_{1 \text { га }}$ - відрахування із заробітної плати, грн/га.;

$\mathrm{AB}_{\text {рік }}$ - сума амортизаційних відрахувань за рік, грн.

Аля визначення собівартості виконання гектару основних видів польових робіт витрати на поточний технічний сервіс визначалися, виходячи 3 щорічних відрахувань від вартості технічного засобу у розмірі $5 \%$ поточні ремонти [8]. Розмір заробітної плати механізаторів визначається до тарифних ставок розрядів робіт, які залежать від мінімальної заробітної плати та міжрозрядних коефіцієнтів (у механізаторів встановлено шостий розряд) [9]. Станом на 01.01.2021 р. сума мінімальної заробітної плати становить 6 тис. грн, погодинна заробітна плата відповідно складає 36,11 грн/годину, тарифний коефіцієнт становить для шостого розряду 1,45 . Стосовно єдиного соціального внеску, розмір станом на 01.01.2021 р. складає $22 \%$. Витрати на паливо, згідно із технічними характеристиками технічних засобів, витрати палива представлені в таблиці 3.14, тому палива визначалися, враховуючи середню вартості дизпалива 29,68 грн (станом на 13.10.21р.) [9]. Амортизаційних відрахування визначалися від вартості технічного засобу, при врахуванні строку використання технічних засобів 10 років. У результаті розрахунків собівартості гектару виконання робіт власними технічними засобами отримали наступні результати:

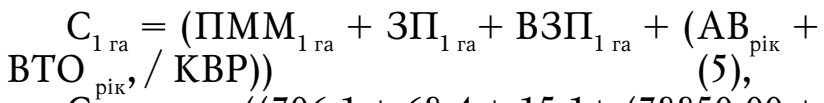

$\mathrm{C}_{1 \text { рік }}^{\text {ріранка }}=((706,1+68,4+15,1+(78850,00+$ $3942,5)(200,0))=1203,5$ грн $/$ га.

$\mathrm{C}_{1 \text { га культив. }}=((286,2+17,0+3,7+(77050,0+$ $3852,5) / 200,0))=711,3$ грн $/$ га.

$\mathrm{C}_{1 \text { га внес. добр. }}=((54,3+17,0+3,7+(20700,0+$ $1035,0) / 200,0))=183,7$ грн/га.

$\mathrm{C}_{1 \text { га м. захист }}=((45,3+10,7+2,4+(19750,0+$ $987,50) / 200))=162,0$ грн/га.

$$
\mathrm{C}_{1 \text { га посів }}=((97,8+17,0+3,7+(53380,4+2669,0)
$$

$/ 200))=398,8$ грн/га.

$\mathrm{C}_{1 \text { га м.з бір урожаю }}=((230,0+25,3+5,6+(252830,00$ $+12641,50) / 200))=1597,2$ грн/га.

Наступним етапом буде визначення загальної суми витрат на гектар та в рік для сільгоспвиробника з врахуванням площі сільгоспугідь $\left(\mathrm{B}_{\mathrm{S}}\right.$ га, $\left.\mathrm{B}_{\mathrm{S}}{ }^{\mathrm{pi \kappa}}\right)$, які можна отримати в результаті підсумку результатів розрахунків визначення суми необхідних вкладень на 1 гектар сільгоспугідь $\left(\mathrm{B}_{1 \text { га }}\right)$ та розрахунків собівартості виконання 1 гектару робіт $\left(\mathrm{C}_{1 \text { га }}\right)(5)$ :

$$
\mathrm{B}_{\mathrm{S} \text { ra }}=\mathrm{B}_{\mathrm{ra}}+\mathrm{C}_{\mathrm{ra}}=\left(((\mathrm{BT} / \mathrm{n}+\mathrm{BA}) / \mathrm{TE}) /\left(\Pi_{1 \text { год. }} * \mathrm{~T}_{\text {річна, год }}\right)\right)
$$
$+\left(\left(\Pi^{2} M_{1 \text { га }}^{\text {ra }}+3 \Pi_{1 \text { га }}+\mathrm{B}^{\text {ra }} \Pi_{1 \text { га }}+\left(\mathrm{AB}_{\text {piк }}+\mathrm{BTO}_{\text {рік }},\right)\right.\right.$ $\mathrm{KBP}))$

$$
\mathrm{B}_{\mathrm{S}}{ }^{\mathrm{pi \kappa}}=\left(\mathrm{B}_{\mathrm{ra}}+\mathrm{C}_{\mathrm{ra}}\right) * \mathrm{~S}=\left(\left(((\mathrm{BT} / 2+\mathrm{BA}) / \mathrm{TE}) /\left(\Pi_{1 \text { roa }} *\right.\right.\right.
$$
$\left.\left.\mathrm{T}_{\text {piqна, го }}\right)\right)+\left(\left(\Pi_{\mathrm{S}}^{\text {ra }} \mathrm{MM}_{1 \text { га }}+3 \Pi_{1 \text { га }}+\mathrm{B} 3 \Pi_{1 \text { га }}+\left(\mathrm{AB}_{\text {рік }}+\right.\right.\right.$ $\left.\left.\left.\mathrm{BTO}_{\text {рік }}^{\text {piqна, го }}, / \mathrm{KBP}\right)\right)\right) * \mathrm{~S}$

де $\mathrm{B}_{\mathrm{S}}{ }^{\text {ra }}$ - витрати на гектар сільгоспуг, грн/ га.; 
Таблиця 3. Визначення доцільності придбання основних видів технічних засобів сільськогосподарському виробнику із площею сільгоспугідь 200 гектар, який спеціалізується на вирощуванні зернових культур

\begin{tabular}{|c|c|c|c|c|c|c|c|c|}
\hline 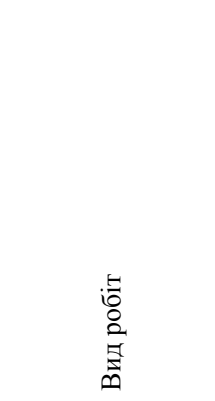 & 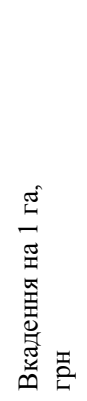 & 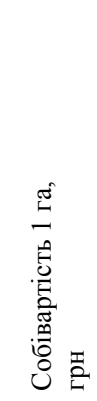 & 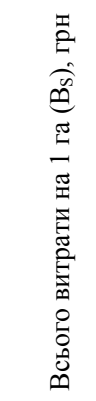 & 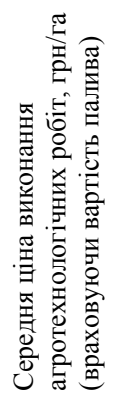 & 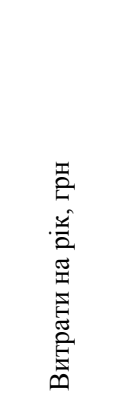 & 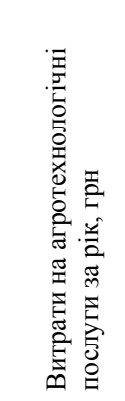 & 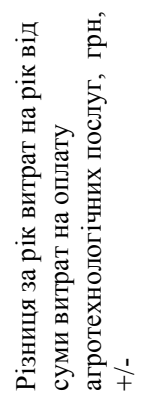 & 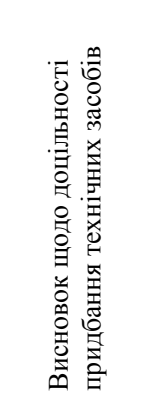 \\
\hline Оранка & 294,4 & 1203,5 & 1498,0 & 1424,6 & 299597,4 & 284910,0 & $+14687,4$ & Недоцільно \\
\hline Культивація & 44,9 & 711,3 & 756,2 & 1080,3 & 151239,2 & 216052,4 & $-64813,2$ & Доцільно \\
\hline Внесення добрив & 2,6 & 183,7 & 186,3 & 890,3 & 37267,5 & 178062,0 & $-140794,5$ & Доцільно \\
\hline Посів & 28,0 & 398,8 & 426,8 & 925,9 & 85359,3 & 185185,2 & $-99825,9$ & Доцільно \\
\hline $\begin{array}{l}\text { Захист } \\
\text { сільгоспкультур }\end{array}$ & 4,1 & 162,0 & 166,2 & 882,9 & 33236,2 & 176578,0 & $-143341,8$ & Доцільно \\
\hline $\begin{array}{l}\text { Збір урожаю } \\
\text { зернових }\end{array}$ & 116,1 & 1597,2 & 1713,2 & 1041,7 & 342648,3 & 208335,6 & $+134312,7$ & Недоцільно \\
\hline
\end{tabular}

Ажерело: розраховано автором.

$\mathrm{B}_{\mathrm{S}}$ рік - витрати на рік в залежності від площі сільгоспугідь, грн/рік;

S - площа сільськогосподарських угідь.

Після визначення суми витрат на рік в залежності від площі сільськогосподарських угідь отриману суму необхідно порівняти із витратами на агротехнологічні послуги сторонніх організацій $\left(\mathrm{B}_{\text {а.п }}\right)$ для відповідної площу сільгоспугідь та обрати економічно доцільніший варіант.

$$
\mathrm{B}_{\text {а.п. }}=Ц_{\text {га }} * \mathrm{~S}
$$

де $\mathrm{B}_{\text {а.п. }}$ - сума витрат на виконання агротехнологічних робіт, грн/га,

$Ц_{\text {га }}$ - ціна виконання гектару агротехнологічних робіт (враховуючи витрати на паливомастильні матеріали), грн/га,

S - площа сільгоспугідь, на якій необхідно виконати агротехнологічні роботи, гектар.

Результати розрахунків доцільності придбання власних технічних засобів представлено в таблиці 3, з якої можна скласти наступні висновки.

По-перше, загальна сума витрат по виконанню робіт з оранки власними технічними засобами більша від витрат на оплату за надання агротехнологічних послуг на 14687,4 грн, тоді як роботи 3 культивації навпаки, виконувати власними технічними економічно вигідніше, оскільки сума економії становить 64813,2 грн/ сезон. Враховуючи, що виконання робіт з оранки та культивації рекомендується виконувати одним трактором з відповідним причіпним обладнанням, загальна сума перевищення витрат на оранку та культивацію складає $-50125,8$ грн/рік, що підтверджує недоцільність придбання трактора та відповідних агрегатів для аграрія із площею сільгоспугідь 200 гектар для виконання робіт з оранки та культивації.

По-друге, по виконанню робіт із внесення добрив, захисту сільськогосподарських культур та посіву, очевидна доцільність придбання трактора МТ3-920 із причіпним обладнанням Аля виконання вказаних робіт, оскільки сума витрат при використанні послуг сторонніх організацій перевищує загальну суму витрат виконання робіт власним трактором із внесення добрив на $-140794,5$ грн/сезон, посіву на -99825,9 грн/сезон та захисту сільгоспкультур на $-143341,8$ грн/сезон.

По-третє, по виконанню робіт зі збору урожаю, сума перевищення витрат по виконанню робіт власними технічними засобами перевищує суму витрат у випадку використання у виробничій діяльності агротехнологічних послуг на 134312,7 грн/сезон, що показує недоцільність придбання власного комбайну для аграрія із площею сільгоспугідь 200 гектар.

Причинами різних результатів розрахунків виступають різна вартість технічних засобів, продуктивність окремих видів робіт, кількість виконуваних робіт трактором чи комбайном.

Наступним етапом дослідження було визначення граничної межі площі сільгоспугідь, при якій доцільно придбати технічні засоби або оплачувати агротехнологічні послуги сторонніх організацій. Аля розв'язання поставленої задачі нами було виконано аналогічні роз- 
Таблиця 4. Загальна сума витрат за сезон для сільгоспвиробників при використанні для виконання основних видів агротехнологічних операцій власних технічних засобів та витрат за сезон на оплату агротехнологічних послуг стороннім організаціям

\begin{tabular}{|c|c|c|c|c|c|c|c|c|c|c|c|c|c|c|c|c|}
\hline \multirow[b]{2}{*}{$\begin{array}{l}\text { Вид } \\
\text { робіт }\end{array}$} & \multicolumn{2}{|c|}{$\begin{array}{c}\text { Сільгоспугіддя } \\
\text { площею } \\
50,0 \text { га } \\
\end{array}$} & \multicolumn{2}{|c|}{$\begin{array}{c}\text { Сільгоспугіддя } \\
\text { площею } \\
100,0 \text { га }\end{array}$} & \multicolumn{2}{|c|}{$\begin{array}{c}\text { Сільгоспугіддя } \\
\text { площею } \\
150,0 \text { га }\end{array}$} & \multicolumn{2}{|c|}{$\begin{array}{c}\text { Сільгоспугіддя } \\
\text { площею } \\
250,0 \text { га } \\
\end{array}$} & \multicolumn{2}{|c|}{\begin{tabular}{|c} 
Сільгоспугіддя \\
площею \\
300,0 га \\
\end{tabular}} & \multicolumn{2}{|c|}{\begin{tabular}{|c|} 
Сільгоспугіддя \\
площею \\
350,0 га \\
\end{tabular}} & \multicolumn{2}{|c|}{\begin{tabular}{|c|} 
Сільгоспугіддя \\
площею \\
400,0 га \\
\end{tabular}} & \multicolumn{2}{|c|}{$\begin{array}{c}\text { Сільгоспугіддя } \\
\text { площею } \\
500,0 \text { га } \\
\end{array}$} \\
\hline & 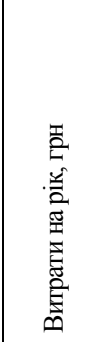 & 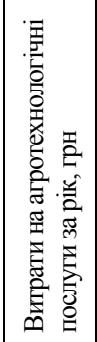 & 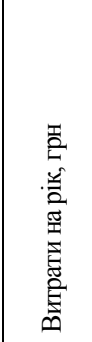 & 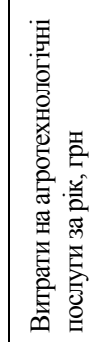 & 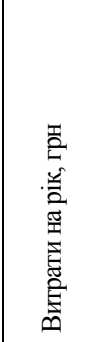 & 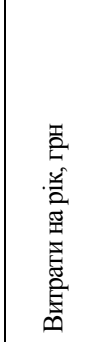 & 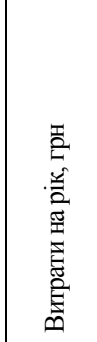 & 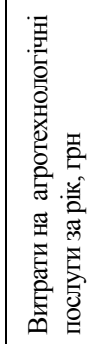 & 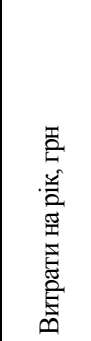 & 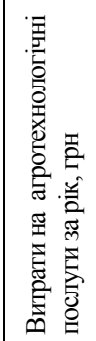 & 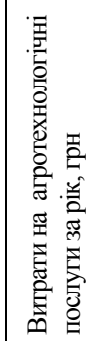 & 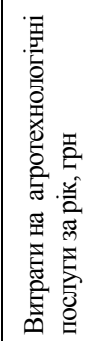 & 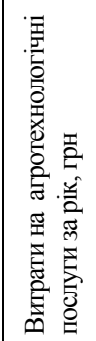 & 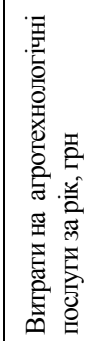 & 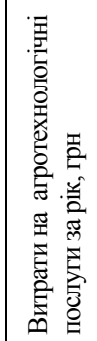 & 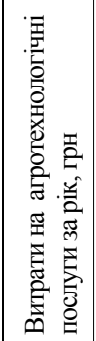 \\
\hline & 1159,8 & 1227,5 & 220639,0 & 142455,0 & 260118,2 & 213682,5 & 339076,6 & 356137,5 & 378555,8 & 427365,0 & 418035,0 & 498592,5 & 457514,2 & 569820,0 & 536472,6 & 712275,0 \\
\hline $\begin{array}{l}\text { Культи- } \\
\text { вація }\end{array}$ & 105218,0 & 54013,1 & 120558,4 & 108026,2 & 135898,8 & 162039,3 & 166579,6 & 270065,5 & 181920,0 & 324078,6 & 197260,4 & 378091,7 & 212600,8 & 432104,8 & 243281,6 & 540131,0 \\
\hline Внесення & 26007,5 & 44515,5 & 29760,8 & 89031,0 & 33514,2 & 133546,5 & 41020,8 & 222577,5 & 44774,2 & 267093,0 & 48527,5 & 311608,5 & 52280,8 & 356124,0 & 59787,5 & 15155 , \\
\hline Посів & 67581,5 & 46296,3 & 73507,5 & 92592,6 & 9433,4 & 138888,9 & 91285,2 & 231481,5 & 97211,1 & 277777,8 & 103137,0 & 324074,1 & 109062,9 & 370370,4 & 120914,7 & 462963,0 \\
\hline Захист & 24483,3 & 44144,5 & 27401,0 & 88289,0 & 30318,6 & 132433,5 & 36153,8 & 220722,5 & 39071,5 & 264867,0 & 41989,1 & 309011,5 & 44906,7 & 353156,0 & 50742,0 & 441445,0 \\
\hline $\begin{array}{l}\text { Збір } \\
\text { урожаю } \\
\text { зернових }\end{array}$ & 302178,2 & 52083,9 & 315668,3 & 104167,8 & 329158,3 & 156251,7 & 356138,4 & 260419,5 & 369628,4 & 312503,4 & 383118,4 & 364587,3 & 396608,4 & 416671,2 & 423588,5 & 520839,0 \\
\hline
\end{tabular}

Ажерело: складено та розраховано автором.

рахунки для сільськогосподарських виробників із площею сільгоспугідь 50, 100, 150, 250, 300, 350, 400, 450 та 500 гектар, які також спеціалізуються на вирощуванні зернових культур, результати яких представлені в таблиці 4.
Вказані висновки підтверджуються діаграмою, на якій зображено для сільськогосподарських виробників із площею сільгоспугідь 50, 100, 200, 300, 400 та 500 гектар різниця між витратами за рік при виконанні основних агро-

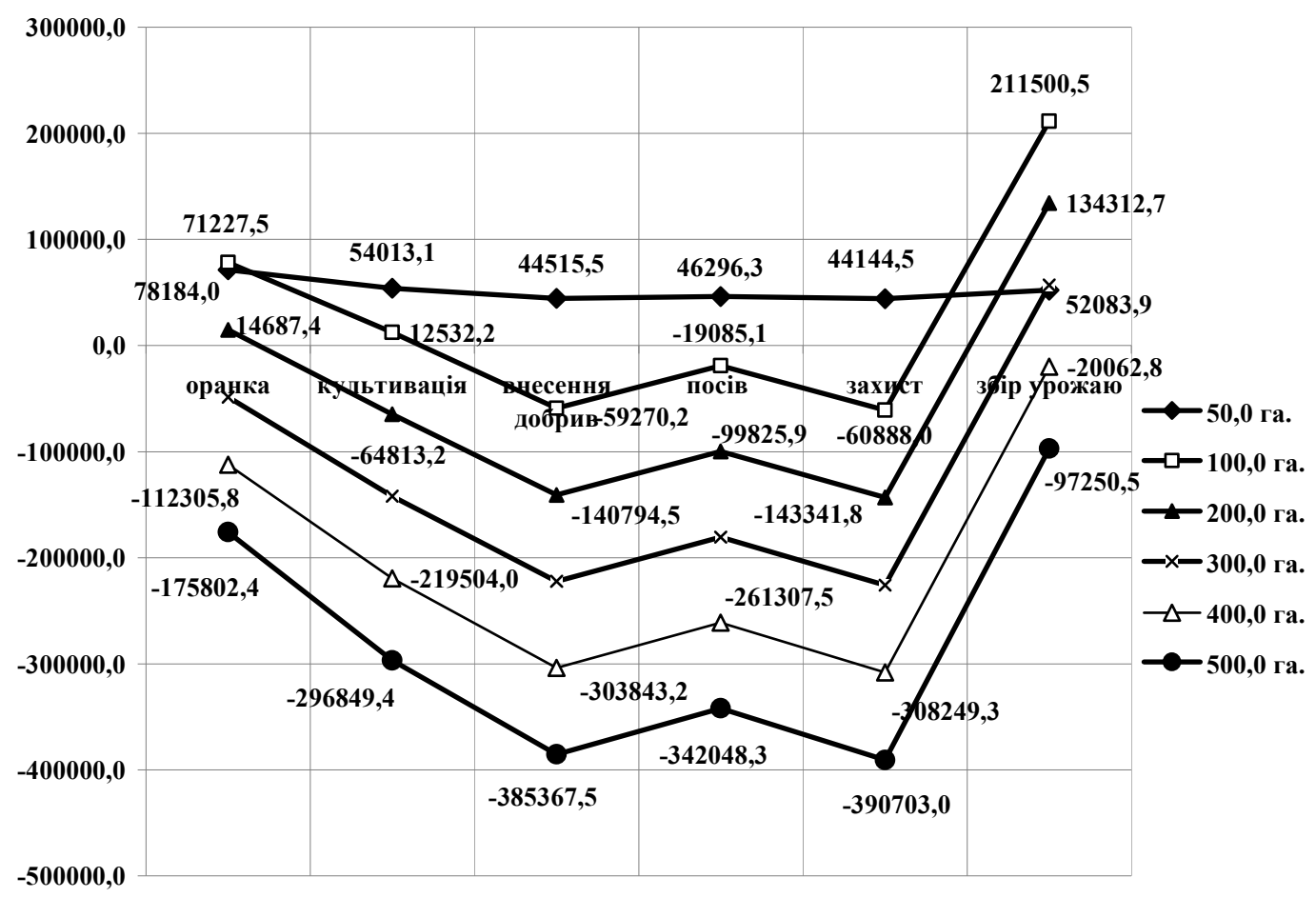

Рис. 1. Різниця між вартістю агротехнологічних послуг та загальною сумою витрат при виконанні робіт власними технічними засобами у сільгоспвиробників із площею сільгоспугідь до 500 гектар 
технологічних операцій власними технічними засобами та у випадку оплати агротехнологічних послуг стороннім організаціям (рис. 1).

У результаті порівняння витрат на виконання основних видів агротехнологічних операцій власними технічними засобами та технічними засобами агротехнологічних обслуговуючих підприємств для сільськогосподарських виробників із площею сільгоспугідь до 500 гектар можна скласти такі висновки:

по-перше, доцільно мати весь комплекс власних технічних засобів та не використовувати у виробничій діяльності агротехнологічні послуги сторонніх організацій сільськогосподарським виробникам, які мають площу сільгоспугідь від 400 гектар;

по-друге, для аграріїв із площею сільгоспугідь до 400 гектар доцільність придбання технічних засобів залежить від виду агротехнологічних послуг, яких потребує виробничий процес: по виконанню робіт з оранки та культивації аграріям із площею сільгоспугідь до 200 гектар доцільно використовувати у виробничій діяльності агротехнологічні послуги сторонніх організацій, аграріям, які мають площу сільгоспугідь більше за 200 гектар, доцільно мати в наявності власні технічні засоби для виконання робіт з оранки та культивації;

по-третє, для виконання робіт з посіву, внесення добрив та захисту сільськогосподарських культур, враховуючи можливість виконання трьох видів польових робіт, нижчу вартість трактора для виконання вказаних робіт та причіпного обладнання до нього, високу продуктивність та в рази нижчі витрати палива, доцільно мати в наявності власні технічні засоби та не застосовувати у виробничій діяльності агротехнологічні послуги для виконання вказаних робіт сільськогосподарським виробникам із площею сільгоспугідь від 50 гектар;

по-четверте, Аля виконання робіт зі збору урожаю доцільно мати власний комбайн сільськогосподарським виробникам із площею сільгоспугідь від 400 гектар.

Сільськогосподарські виробники із площею сільгоспугідь до 500 гектар при прийнятті рішення стосовно доцільності придбання технічних засобів можуть використовувати запропоновану запропоновану модель для розрахунку загальної суми витрат на виконання польових робіт та їі застосування дасть можливість сільгоспвиробникам порівняти загальну суму витрат на виконання польових робіт з вартістю вказаних робіт у агротехнологічних обслуговуючих підприємств, що дасть можливість обрати економічно доцільніший варіант.

\section{ВИСНОВКИ З ПРОВЕДЕНОГО ДОСЛІДЖЕННЯ І ПЕРСПЕКТИВИ ПОДАЛЬШИХ РОЗВІДОК У ЦЬОМУ НАПРЯМ}

У результаті визначення граничної межі площі сільськогосподарських угідь, при якій доцільно мати в наявності власні технічні засоби та площі сільгоспугідь, при якій доцільно використовувати у виробничій діяльності послуги сторонніх організацій можна підвести підсумок, що мати весь комплекс власних технічних засобів та не використовувати у виробничій діяльності агротехнологічні послуги сторонніх організацій сільськогосподарським виробникам, які мають площу сільгоспугідь від 400 гектар, Аля аграріїв із площею сільгоспугідь до 400 гектар доцільність придбання технічних засобів залежить від виду агротехнологічних послуг, яких потребує виробничий процес.

Використання розробленої моделі для розрахунку загальної суми витрат на виконання основних видів польових робіт дасть можливість сільгоспвиробникам із площею сільгоспугідь до 500 гектар порівняти загальну суму витрат на виконання польових робіт з вартістю вказаних робіт у агротехнологічних обслуговуючих підприємств, що призведе до вибору аграріями економічно доцільнішого варіанту. Реалізація вказаних пропозицій сприятиме розвитку виробничої діяльності аграріїв із площею сільськогосподарських угідь до 500 гектар. Аостатнє, що відповідає сучасним вимогам, забезпечення виробничого процесу агротехнологічними послугами та власними технічними засобами сільськогосподарських виробників (як представників агробізнесу, так і особистих селянських домогосподарств) сприятиме зростанню їх фінансово-економічних показників та рівню конкурентоспроможності.

\section{$\Lambda$ iтература:}

1. Кропивко М.Ф., Кісіль М.І. Теоретичні засади і методичні підходи до формування стратегії управління ефективністю інвестицій фермерського господарства. Економіка АПК. 2021. № 1. С. $6-14$.

2. Визначення вартості надання агротехнічних послуг та оренди сільськогосподарської техніки / Кропивко М.Ф. та ін. Київ: IAE, 2005. $20 \mathrm{c}$.

3. Аелюк О.О. Управління витратами на формування техніко-технологічного потенціалу аграрних підприємств. Вчені записки університету "Крок". 2016. Вип. 43 С. 149-155.

4. Організація підприємницької діяльності в сільськогосподарських підприємствах: прак- 
тикум / [Шкільов О.В.]; за ред. О.В. Шкільова. Київ: НУБІП, 2011. 216 с.

5. Витрати палива і норми продуктивності для сільськогосподарської техніки, яка використовується для проведення кваліфікаційної експертизи сортів рослин у філіях кваліфікаційної експертизи сортів рослин: науково-методичні рекомендації / Авт. кол.: С.І. Мельник, В.С. Пивовар та ін.; Український інститут експертизи сортів рослин. Вінниця: ТОВ "Твори", 2020, 68 c.

6. Моссаковський В.Б., Костякова А.А., Кононенко Т.В. Особливості розрахунку точки беззбитковості в аграрній сфері. Економіка АПК. 2009. № 9. С. 73-78.

7. Аержавна служба статистики України. URL: http://www.ukrstat.gov.ua (дата звернення: 20.08.2021).

8. Агропортал "Пропозиція - все про агропромисловий комплекс". URL: https://propozitsiya.com/ua/ekonomika-procesiv-zbyrannyazernovyh (дата звернення: 01.12.2021р.).

9. Аграрний торговельний майданчик "Agrobiz".URL:https://agrobiz.net/search/?terms=\%D0\%9E\%D0\%9F-800 (дата звернення: 08.12.2021).

References:

1. Kropyvko, M.F. and Kisil, M.I. (2021), "Theoretical bases and methodical approaches to formation of strategy of management of efficiency of investments of a farm", Ekonomika APK, vol. 1, pp. 6-14.

2. Kropyvko, M.F. (2005), Vyznachennia vartosti nadannia ahrotekhnichnykh posluh ta orendy silskohospodarskoi tekhniky [Determining the cost of agricultural services and rental of agricultural machinery], IAE, Kyiv, Ukraine.

3. Leliuk, O.O. (2016), "Cost management for the formation of technical and technological potential of agricultural enterprises", Vcheni zapysky universytetu "Krok", vol. 43, pp. 149-155.

4. Shkilov, O.V. (2011), Orhanizatsiia pidpryiemnytskoi dialnosti v silskohospodarskykh pidpryiemstvakh: praktykum [Organization of entrepreneurial activity in agricultural enterprises: workshop], NUBIP, Kyiv, Ukraine.

5. Melnyk, S.I. and Pyvovar, V.S. (2020), Vytraty palyva i normy produktyvnosti dlia silskohospodarskoi tekhniky, yaka vykorystovuietsia dlia provedennia kvalifikatsiinoi ekspertyzy sortiv roslyn u filiiakh kvalifikatsiinoi ekspertyzy sortiv roslyn [Fuel consumption and productivity standards for agricultural machinery used for the qualification examination of plant varieties in the branches of the qualification examination of plant varieties], Ukrainskyi instytut ekspertyzy sortiv roslyn, TOV "Tvory", Vinnytsia, Ukraine.

6. Mossakovskyi, V.B. Kostiakova, A.A. and Kononenko, T.V. (2009), "Features of calculating the break-even point in the agricultural sector", Ekonomika APK, vol. 9, pp. 73-78.

7. Derzhavna sluzhba statystyky Ukrainy, available at: http://www.ukrstat.gov.ua (Accessed 15 Dec 2021).

8. Ahroportal "Propozytsiia - vse pro ahropromyslovyi kompleks", available at: https://propozitsiya.com/ua/ekonomika-procesiv-zbyrannya-zernovyh (Accessed 15 Dec 2021).

9. Ahrarnyi torhovelnyi maidanchyk "Agrobiz", available at: https://agrobiz.net/search/ ?terms $=\% \mathrm{D} 0 \% 9 \mathrm{E} \% \mathrm{D} 0 \% 9 \mathrm{~F}-800$ (Accessed $15 \mathrm{Dec}$ 2021).

Стаття надійшла до редакиії 21.12.2021 p.

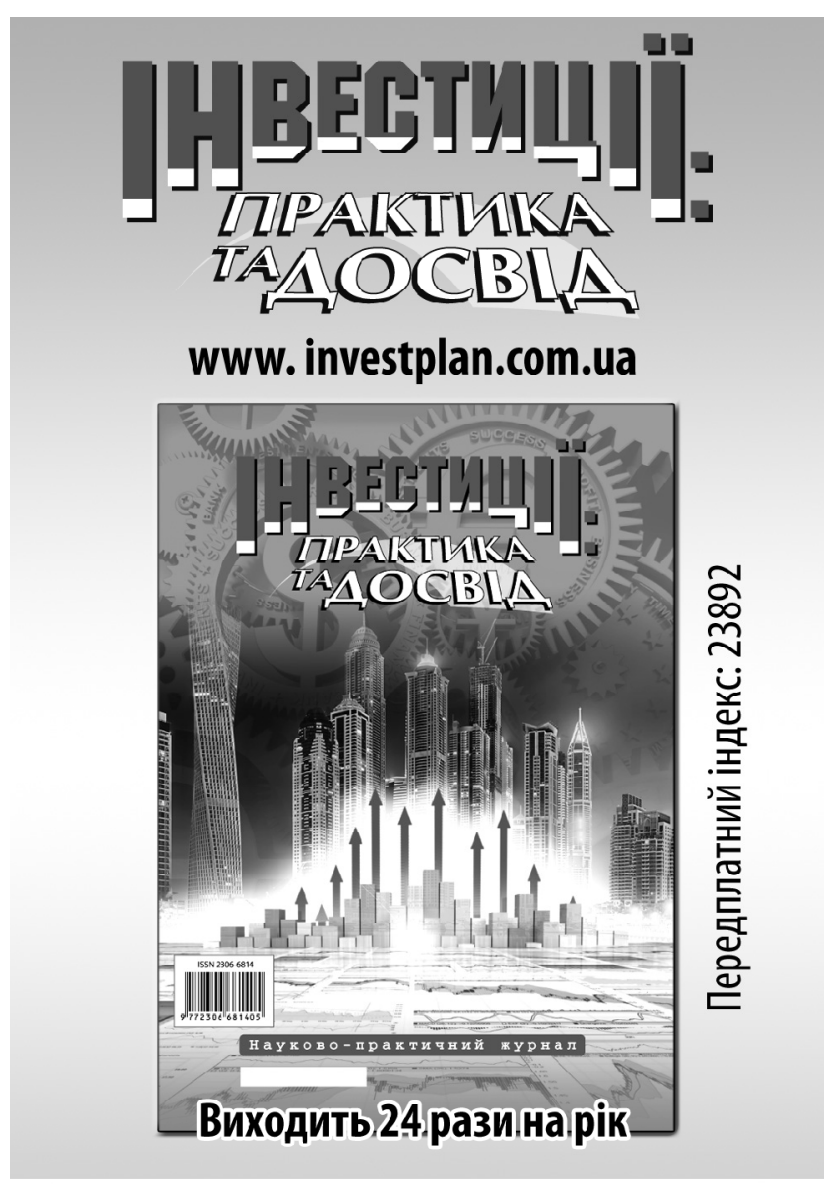

Журнал включено до переліку наукових фрахових видань України (Категорія «Б») 3

ЕКОНОМІЧНИХ НАУК та ДЕРЖАВНОГО УПРАВЛІННЯ

(Наказ Міністерства освіти і науки України № 886 від 02.07.2020)

Спеціальності - 051, 071, 072, 073, 075, 076, 281, 292 
УAK 336.143

\author{
B. I. Чугунов, \\ аспірант кафедри фінансів, \\ Київський національний торговельно-економічний університет, м. Київ \\ ORCID ID: 0000-0003-1292-6612
}

\title{
БЮАЖЕТНА ПОАІТИКА ЕКОНОМІЧНОГО ЗРОСТАННЯ
}

\author{
V. Chugunov, \\ Postgraduate student of the Department of Finance, Kyiv National University of Trade and Economics, Kyiv
}

\section{BUDGET POLICY OF ECONOMIC GROWTH}

У статті розкрито питання сутності бюджетної політики економічного зростання. Важливим $є$, що бюАжетна політика $є$ ефективним засобом регулювання соціально-економічного розвитку країни. Система бюАжетного регулювання базується на цілісній сукупності фінансових та економічних взаємовідносин, інституційних бюджетних елементів стосовно вибору й реалізації головних напрямів здійснення бюАжетної політики, планування та прогнозування основних бюджетних показників, напрямів використання бюджетних ресурсів, досягнення запланованих соціально-економічних цілей й завдань. Визначено, що $з$ метою підвищення результативності бюджетної політики як складової державного регулювання економіки необхідним є посилення взаємозв'язку бюджетного планування із циклічністю економіки, проведення збалансованої бюджетної політики. Бюджетна політика є активним інструментом економічної політики держави, в сучасних умовах одним з першочергових їі завдань є забезпечення фінансової стійкості та збалансованості бюджетної системи. Бюджетна політика є ефективним засобом регулювання соціально-економічного розвитку країни. Система бюджетного регулювання базується на цілісній сукупності фінансових та економічних взаємовідносин, інституційних бюджетних елементів стосовно вибору й реалізації головних напрямів зАійснення бюджетної політики, планування та прогнозування основних бюджетних показників, напрямів використання бюджетних ресурсів, досягнення запланованих соціально-економічних цілей й завдань. Інституційний підхіА включає аналіз бюджетного регулювання як цілісної та динамічної системи, яка постійно вдосконалюється відповіАно до головних макроекономічних завдань розвитку країни. Показано, що становлення інституту бюджетної політики є вагомою складовою удосконалення бюджетної системи в процесі визначення концептуальних засад та основних завдань інституційних перетворень відповідно Ао соціально-економічного розвитку країни. Бюджетна політика економічного розвитку має грунтуватись на сукупності фундаментальних трансформації системи бюджетного регулювання, вагомим $є$ формування ефективної та транспарентної бюджетної системи; зниження податкового навантаження на економічну систему, використання фіскальних інструментів активізації економічного зростання; посилення соціального спрямування бюджетної та податкової системи; зростання фіскального забезпечення бюджетів місцевого самоврядування. На сучасному етапі економічних перетворень доцільним $є$ підвищення рівня аАаптивності бюАжетної системи, вдосконалення інструментарію бюджетного планування та прогнозування.

The article reveals the essence of fiscal policy of economic growth. It is important that fiscal policy is an effective means of regulating the socio-economic development of the country. The system of budget regulation is based on a holistic set of financial and economic relations, institutional budget elements for the selection and implementation of the main directions of budget policy, planning and forecasting key budget indicators, areas of budget resources, achieving planned socio-economic goals and objectives. It is determined that in order to increase the effectiveness of budget policy as a component of state regulation of the economy, it is necessary to strengthen the relationship between budget planning and cyclical economy, a balanced budget policy. Budget policy is an active tool of economic policy of the state, in modern conditions one of its priority tasks is to ensure financial stability and balance of the budget system. The system of budget regulation is based on a holistic set of financial and economic relations, institutional budget elements for the selection 
and implementation of the main directions of budget policy, planning and forecasting key budget indicators, areas of budget resources, achieving planned socio-economic goals and objectives. The institutional approach includes the analysis of budget regulation as a holistic and dynamic system, which is constantly improving in accordance with the main macroeconomic objectives of the country. It is shown that the formation of the institution of budget policy is an important component of improving the budget system in the process of defining the conceptual foundations and main tasks of institutional transformation in accordance with the socio-economic development of the country. Budget policy of economic development should be based on a set of fundamental transformations of the budget regulation system, it is important to form an effective and transparent budget system; reduction of the tax burden on the economic system, the use of fiscal instruments to stimulate economic growth; strengthening the social orientation of the budget and tax system; growth of fiscal support of local government budgets. At the present stage of economic transformations it is expedient to increase the effectiveness of the mechanism for regulating economic processes, increase the level of adaptability of the budget system, improve the tools of budget planning and forecasting.

Ключові слова: бюджет, бюджетна політика, бюджетне планування, бюджетне регулювання, бюджетний механізм, економічне зростання.

Key words: budget, budget policy, budget planning, budget regulation, budget mechanism, economic growth.

\section{ПОСТАНОВКА ПРОБЛЕМИ}

Розвиток суспільства та стратегічні пріоритети України зумовлюють посилення уваги до обгрунтованості та дієвості бюджетної політики у системі державного регулювання економіки. Трансформація цілей і завдань бюджетної політики, що обумовлена посиленням впливу ендогенних та екзогенних факторів на соціально-економічні процеси в країні, актуалізує необхідність формування дієвого механізму реалізації бюджетної політики з метою забезпечення сталого економічного зростання. Становлення інституту бюджетної політики $€$ вагомою складовою удосконалення бюджетної системи в процесі визначення концептуальних засад та основних завдань інституційних перетворень відповідно до соціально-економічного розвитку країни. На сучасному етапі економічних перетворень доцільним $€$ посилення дієвості реалізації механізму регулювання економічних процесів, підвищення рівня адаптивності бюджетної системи, вдосконалення інструментарію бюджетного планування та прогнозування. Враховуючи важливість вирішення завдань бюджетного регулювання, забезпечення єАності економічної та фінансової політики, розробка пріоритетів бюджетної політики має грунтуватися на стратегічних завданнях сталого розвитку. Водночас фінансова стійкість і макроекономічна стабільність є основними умовами для підтримки економічного зростання у середньо- та довгостроковому періоді. Суттєвий рівень фіскального дефіциту, значний рівень державного боргу можуть стримувати приватні інвестиції і знижувати темпи економічного розвитку. Бюджетна політика $є$ актив- ним інструментом економічної політики держави, в сучасних умовах одним з першочергових її завдань є забезпечення фінансової стійкості та збалансованості бюджетної системи. 3 метою підвищення результативності бюджетної політики як складової державного регулювання економіки необхідним $є$ посилення взаємозв'язку бюджетного планування із циклічністю економіки, проведення збалансованої бюджетної політики.

\section{АНАЛІЗ ОСТАННІХ ДОСЛІДЖЕНЬ І ПУБЛІКАЦІЙ}

Серед вагомих наукових досліджень зарубіжних вчених у сфері розвитку бюджетних відносин можна назвати праці Аж. Б'юкенена, М. Блауга, А. Вагнера, Аж.М. Кейнса, П. Кругмана, В. Нордхауса [2], К. Рау, Р. Солоу, П. Самуельсона [2], Аж. Стігліца, В. Танзі. Питання бюджетної політики економічного зростання досліджуються у працях вітчизняних вчених: О. Василика, Т. Канєвої [1; 6; 10], Ю. Маркуц [7],

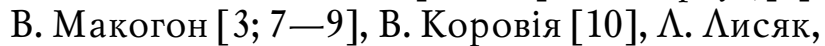
I. $\Lambda$ ук'яненко, М. Пасічного [1; 6; 10], Ю. Радіонова, О. Самошкіної [5], В. Федосова, І. Чугунова $[1 ; 3-10]$ та інших.

\section{МЕТА ДОСЛІДЖЕННЯ}

Метою дослідження $€$ розкриття сутності бюджетної політики економічного зростання.

\section{ВИКЛАД ОСНОВНОГО МАТЕРІАЛУ}

Основним пріоритетним завданням державних та місцевих органів влади має стати зміцнення економічного потенціалу територій, запровадження систем ефективного економічно- 
го управління, основною метою якого є посилення ролі територій, визначення відповідних пріоритетів бюджетної політики, оптимального поєднання місцевих та загальнодержавних інтересів. Бюджетна політика економічного розвитку має грунтуватись на сукупності фундаментальних трансформації системи бюджетного регулювання, вагомим є формування ефективної та транспарентної бюджетної системи; зниження податкового навантаження на економічну систему, використання фіскальних інструментів активізації економічного зростання; посилення соціального спрямування бюджетної та податковӧ̈ системи; зростання фіскального забезпечення бюджетів місцевого самоврядування. Здійснювати бюджетне регулювання необхідно з урахуванням динаміки значень показників фінансової та боргової стійкості. Реалізація механізму регулювання доходної та видаткової частини бюджету впливає на обсяг бюджетного дефіциту, який має фінансуватися за рахунок запозичень. В умовах трансформацій економіки доцільно використовувати бюджетний дефіцит як інструмент стимулювання економічного розвитку, натомість в період економічного підйому важливим $є$ зменшення його рівня або формування бюджету із профіцитом.

Відповідно до стадій економічного циклу, бюджетну політику поділяють на автоматичну та дискреційну. Автоматична бюджетна політика грунтується на функціонуванні вбудованих стабілізаторів, що забезпечують природне пристосування економіки до фаз ділової кон'юнктури. Вагомими вбудованими стабілізаторами виступають прогресивна система оподаткування та система соціальної допомоги. В періоди економічного пожвавлення, внаслідок зростання доходів, податки починають стягуватись за вищими ставками, в результаті чого, темп зростання наявних доходів починає відставати від темпу зростання національного доходу, що стримує зростання споживчого попиту. При цьому зростання доходів знижує витрати держави на соціальні потреби, що зумовлює обмеження зростання сукупного доходу. У періоди рецесії сукупний попит стимулюється засобами бюджетного регулювання. Аискреційна бюджетно-податкова політика характеризується цілеспрямованим регулюванням економічної системи, реалізацією цільових програм впливу на економічне зростання, показники інфляції, безробіття населення. Основна мета бюджетної політики є інтеграція бюджетного планування в процес формування і реалізації довгострокової стратегії суспільного розвит- ку країни, через упровадження принципів програмно-цільового планування і перехід до програмного бюджету.

Важливим напрямом удосконалення бюджетної політики має стати перехід до середньострокового бюджетного планування, передусім, встановлення зв'язку річного та середньострокового бюджетного планування та впровадження програмно-цільового методу бюджетування 3 дотриманням розмірів і умов оплати праці працівників бюджетної сфери, прожиткового мінімуму, зміни тарифів на енергоносії, інших показників, необхідних для планування видатків за бюджетними програмами, термін виконання яких більше одного року. Визначальним у цьому напрямі стане підвищення ефективності видатків, що відбуватиметься на основі визначення їх пріоритетності та оцінки ступеня досягнення очікуваних результатів.

Аержавна фінансова політика в сфері міжбюджетних відносин повинна базуватися на стабільності законодавчо встановленого розмежування видаткових повноважень, нормативів відрахувань від доходів, механізмів формування і надання міжбюджетних трансфертів. Формування міжбюджетних відносин повинно здійснюватися з урахуванням необхідності підвищення їх ефективності, створення стійкої і прозорої системи фінансових відносин на основі поєднання принципів самостійності бюджетів усіх рівнів та єдності їх інтересів. Вирішення поставлених завдань сприятиме підвищенню ефективності системи міжбюджетних відносин, збалансованості місцевих бюджетів і поліпшить якість управління бюджетним процесом на місцевому рівні. Аля досягнення завдань, визначених у стратегічних документах та програмах соціально-економічного розвитку, для підвищення ефективності реалізації проєктів регіонального розвитку, конкурентоспроможності та інвестиційної привабливості країни необхідно розробити дієвий механізм узгодження пріоритетів бюджетної політики та дій місцевого самоврядування, забезпечення концентрації фінансових ресурсів на пріоритетних напрямах соціально-економічного розвитку держави та територій. Основним завданням бюджетної політики має стати трансформація бюджетних ресурсів у чинник економічного зростання. Бюджетні ресурси повинні бути вагомим джерелом інвестицій, що сприятиме підвищенню рівня життя населення.

Основними питаннями, що потребують вирішення в бюджетній системі є удосконалення нормативного забезпечення, підвищення ефективності здійснених видатків бюджету, систе- 
ми управління державним боргом, забезпечення прозорості системи державних фінансів. Поняття бюджетної пріоритетності досить суттєво здійснює вплив на структурні перетворення в економіки країни, соціальній сфері, рівень людського капіталу, на конкурентоспроможність національної економіки. Розвиток громадянського суспільства викдикає потребу щодо відповідних інституційних змін, які мають відбутися у взаємовідносинах між учасниками бюджетного процесу й покращення ефективності бюджетної політики в загальній системі державного впливу на економіку. Важливим $є$ аналіз оцінки ефективності проведення пріоритетних напрямів бюджетної політики як одного із інструментів соціального та економічного розвитку держави та територій; запровадження ефективних бюджетних механізмів у системі інституційного забезпечення розвитку суспільства; покращення показників результативності міжбюджетних відносин та державного фінансового регулювання економіки [1;9].

Бюджетна політика є ефективним інструментом соціально-економічного розвитку країни. Система бюджетного регулювання базується на цілісній сукупності фінансових та економічних взаємовідносин, інституційних бюджетних елементів стосовно вибору й реалізації головних напрямів здійснення бюджетної політики, планування та прогнозування основних бюджетних показників, напрямів використання бюджетних ресурсів, досягнення запланованих соціально-економічних цілей й завдань. Пріоритетним також є застосування регуляторного механізму бюджетної політики, що грунтується на поєднанні бюджетного регулювання в системі доходів та видатків бюджету, міжбюджетних відносин та державного боргу. Задля розробки та впровадження фінансовобюджетного регулювання на протязі певного періоду бюджетна політика повинна розроблятися на основі циклічності економічного розвитку фінансової системи, стану державних фінансів та запасу стійкості бюджетної системи, бюджетного регулювання щодо позитивного впливу на показники економічного зростання. Інституційний підхід включає аналіз бюджетного регулювання як цілісної та динамічної системи, яка постійно вдосконадюється відповідно до головних макроекономічних завдань розвитку країни. Бюджетна політика має на меті згладжувати коливання економічного циклу та базується на стимулюванні державою сукупного попиту шляхом збільшення видатків бюджету та зменшення податкового навантаження в період спаду, в результаті чого відбу- вається вирівнювання показників економічного розвитку. При зниженні рівня доходів бюджету доцільним $€$ не зменшення видаткової частини бюджету, а фінансування зниження податкових надходжень через позикові інструменти. В періоди економічного пожвавлення надходження бюджету необхідно використовувати не для збільшення державного споживання, а з метою підвищення показників фінансових заощаджень та нарощення державних резервів. На стадії підйому країна має можливості виплатити боргові зобов'язання, що були сформовані за час спаду економічної активності.

Характерними ознаками суспільного розвитку є зростання показників доходу на валового внутрішнього продукту на душу населення, зниження рівня бідності, значної диференціації в одержуваних доходах, досягнення соціальної справедливості. Важливим є дослідження динаміки індексу людського розвитку, який $€$ інтегрованим показником та включає оцінку стану очікуваної тривалості життя, рівня доходів та якості освіти. Водночас більшою мірою, питання розвитку суспільства ототожнюється з економічним зростанням, а саме ростом реального валового внутрішнього продукту. При цьому слід розрізняти певні аспекти економічного розвитку: довгостроковий економічний розвиток який є структурною складовою розвитку та характеризує показник потенційного виробництва товарів та надання послуг. Вплив на довгострокову складову здійснюють фундаментальні фактори, кількість та якісний рівень капіталу, засобів праці та робочої сили, інституційне середовище економіки. Водночас суттєве розбалансування бюджетної системи та накопичення державного боргу знижують рівень довіри учасників ринку до облігацій державної позики та можливостей платоспроможності позичальника. У такому випадку держава вимушена запроваджувати бюджетні обмеження, здійснювати структурні перетворення системи державних фінансів, адаптувати фінансово-бюджетну політику до умов рецесії. Зазначене обумовлює зміну підходів до формування та реалізації бюджетної політики, формування нових індикативних орієнтирів їі розвитку в коротко-, середньо- та довгостроковій перспективі.

Короткострокові економічні коливання від рівноважного рівня є кон'юнктурною складовою економічного розвитку та можуть бути викликані зміною попиту та ціни та товари і послуги, що виробляються в країні. Аиференціація складових розвитку є важливою 3 по- 
зиції формування та реалізації заходів бюджетної політики задля стимулювання економічної активності та створення передумов $\dddot{1}$ стійкого зростання. Короткострокова складова охоплює період до трьох років, в цей період часу вагому стабілізаційну роль відіграє бюджетна політика. Водночас доволі дискусійними залишаються питання вибору відповідних фінансових інструментів, важелів та механізмів та оцінки їх ефективності задля досягнення поставлених завдань та цілей. В умовах рецесії можуть застосовуватись антикризові бюджетні заходи, в тому числі щодо підтримки стабільності банківської системи, державних підприємств, субсидіювання пріоритетних галузей економіки, надання податкових преференцій вітчизняним підприємствам. У довгостроковій перспективі, механізм державного інвестування спрямований на підвищення рівня результативності використання відповідними інститутами капіталу та активізації економічного зростання. 3 огляду на зазначене, важливими питаннями, що постають на сучасному етапі розвитку бюджетних відносин є посилення ефективності використання бюджетних коштів на реалізацію відповідних цілей. У процесі формування бюджетної політики мають враховуватись суспільні інтереси, за рахунок виділення відповідних видатків бюджету реалізуються функції і завдання держави. Критерієм ефективності бюджетної політики є досягнення цілей соціально-економічної політики, на реалізацію яких спрямовуються державні фінансові ресурси $[4 ; 6]$.

Основними цілями фінансового забезпечення місцевих бюджетів є підвищення ефективності бюджетних видатків; соціально-економічний розвиток територіальних громад; збільшення інвестиційної складової місцевих бюджетів; реалізація структурних перетворень у бюджетній сфері; фінансова стійкість та збалансованість бюджетів. В умовах трансформаційних перетворень, бюджетна політика $€$ вагомим інструментом забезпечення довгострокової збалансованості, стійкості та стабільності функціонування бюджетної системи, що надає можливість підвищити рівень і якість життя населення, створити умови для досягнення цілей соціально-економічного розвитку країни. Пріоритетними завданнями у бюджетній сфері мають бути підвищення ефективності бюджетної політики; впровадження стимулюючих заходів, спрямованих на активізацію економічної діяльності. Реалізація бюджетної стратегії в умовах економічних перетворень передбачає створення передумов для суспільного розвитку на ос- нові врахування впливу екзогенних та ендогенних факторів економічного зростання, модернізації системи фінансово-економічних відносин та ефективного управління державними фінансами, забезпечення узгодженості фіскальної та економічної політики країни на основі середньострокового бюджетного планування; прозорості та реалістичності формування бюджетів усіх рівнів; дієвості державного фінансового контролю та аудиту ефективності управління бюджетними коштами.

На сучасному етапі розвитку економічних систем, доцільним є використання механізму міжбюджетних відносин, що зумовлено потребами вирішення основних питань соціального та економічного розвитку територій та країни в цілому через підвищення ефективності керуванням фінансовими ресурсами держави та місцевого самоврядування. Збільшення доходів місцевих бюджетів доцільно здійснювати шляхом перерозподілу доходної бази між державним та місцевими бюджетами. Зростання ефективності видатків бюджетних ресурсів на місцевому рівні може відбутися через передачу на місцевий рівень багатьох низки видаткових повноважень, подальший розвиток програмноцільового методу бюджетного планування на місцевому рівні, удосконалення та підвищення ефективності систем моніторингу та оцінювання використання бюджетних коштів, зростання прозорості формування та виконання місцевих бюджетів, використання середньострокового бюджетного планування. Удосконалення міжбюджетних відносин 3 метою досягнення визначених цілей та ефективності, повинно бути тісно пов'язаною із розвитком місцевого самоврядування, що дозволить створити систему адміністративно-територіальних одиниць, які будуть здатні виконувати покладені на них функції та обов'язки. Здійснюючи оптимізацію розподілу й перерозподілу валового внутрішнього продукту при використанні бюджетного механізму, державна постійно регулює соціально-економічні процеси.

Аоходи бюджету є вагомою складовою системи фінансових відносин. Циклічність розвитку економіки в умовах посилення процесів глобалізації зумовлює трансформації структури та обсягу дохідної частини бюджету. Важливим є визначення відповідних інституційних засад формування доходів бюджету в системі бюджетного регулювання з урахуванням необхідності забезпечення належного рівня соціальних стандартів та економічного зростання країни. Від ступеня оптимальності співвідношень між елементами бюджетної системи за- 
лежить рівень збалансованості бюджетного регулювання та ефективність його впливу на суспільний розвиток. Стратегічні пріоритети удосконалення системи формування доходів бюджету передусім перебувають у сфері податкового регулювання. Потребує подальшого удосконалення діюча система пільгового оподаткування. В економічному напряму доцільним $є$ подальше зниження ставки податку на прибуток підприємств на реінвестовану в модернізацію та розширення виробництва частку, імплементацію системи регулювання трансфертного ціноутворення; зменшення податкового навантаження на фонд оплати праці; індексацію відповідно до рівня інфляції акцизного та екологічного оподаткування; поступового зростання рентних та природно-ресурсних платежів. У соціальному напряму важливим $€$ удосконалення прогресивної шкали ставок оподаткування доходів фізичних осіб, доцільним $є$ врахування сімейного стану платника, запровадження оподаткування доходів від розміщення коштів на депозитних рахунках, удосконалення механізму непрямого оподаткування щодо товарів споживання, оподаткування нерухомого майна. Бюджетна політика має бути спрямована на підтримку стійкості національної фінансової системи, від рівня інституційного забезпечення якої залежать економічні можливості країни. Важдивим є підвищення дієвості контролю та аудиту використання фінансових ресурсів держави, підвищення транспарентності бюджетних відносин. Зростання ефективності використання бюджетних ресурсів на всіх етапах бюджетного процесу розпорядниками бюджетних коштів та бюджетними установами забезпечується проведенням якісного внутрішнього контролю та аудиту. Виконуючи функцію попередження, такі форми контролю займають провідне місце на кожній стадії виконання бюджету й забезпечують обгрунтоване прийняття управлінських рішень. Забезпечення довгострокової збалансованості бюджетної системи має грунтуватися на основі зниження показників структурного дефіциту бюджету та боргового навантаження на бюджет, підвищення фіскальної ефективності податкової системи, що з урахуванням раціональної політики в системі формування видатків бюджету, надасть можливість посилити результативність бюджетної політики країни.

\section{вИсновки}

Бюджетна політика $є$ ефективним засобом регулювання соціально-економічного розвитку країни. Система бюджетного регулювання базується на цілісній сукупності фінансових та економічних взаємовідносин, інституційних бюджетних елементів стосовно вибору й реалізації головних напрямів здійснення бюджетної політики, планування та прогнозування основних бюджетних показників, напрямів використання бюджетних ресурсів, досягнення запланованих соціально-економічних цілей й завдань. Інституційний підхід включає аналіз бюджетного регулювання як цілісної та динамічної системи, яка постійно вдосконалюється відповідно до головних макроекономічних завдань розвитку країни. Основними питаннями, що потребують вирішення в бюджетній системі $€$ удосконалення нормативного забезпечення, підвищення ефективності здійснених видатків бюджету, системи управління державним боргом, забезпечення прозорості системи державних фінансів. Поняття бюджетної пріоритетності досить суттєво здійснює вплив на структурні перетворення в економіки країни, соціальній сфері, рівень людського капіталу, на конкурентоспроможність національної економіки. Розвиток громадянського суспільства викликає потребу щодо відповідних інституційних змін, які мають відбутися у взаємовідносинах між учасниками бюджетного процесу й покращення ефективності бюджетної політики в загальній системі державного впливу на економіку. Важливим $є$ аналіз оцінки ефективності проведення пріоритетних напрямів бюджетної політики як одного із інструментів соціального та економічного розвитку держави та територій; запровадження ефективних бюджетних механізмів в системі інституційного забезпечення розвитку суспільства; покращення показників результативності міжбюджетних відносин та державного фінансового регулювання економіки. Пріоритетним також $€$ застосування регуляторного механізму бюджетної політики, що грунтується на поєднанні бюджетного регулювання у системі доходів та видатків бюджету, міжбюджетних відносин та державного боргу. Задля розробки та впровадження фінансово-бюджетного регулювання на протязі певного періоду бюджетна політика повинна розроблятися на основі циклічності економічного розвитку фінансової системи, стану державних фінансів та запасу стійкості бюджетної системи, бюджетного регулювання щодо позитивного впливу на показники економічного зростання.

\section{$\Lambda$ ітература:}

1. Бюджетно-податкова політика у системі регулювання економіки: монографія / І.Я. Чу- 
гунов, Т.В. Канєва, М.А. Пасічний та ін.; за заг. ред. І.Я. Чугунова. К.: Глобус-Пресс, 2018. 354 с.

2. Самуэльсон Пол Э., Нордхаус Вильям А. Экономика. 19-е изд.: пер. с англ. М.: Вильямс, 2015. 1360 c.

3. Чугунов I.Я., Макогон В.А. Бюджетна стратегія в умовах економічних перетворень. Вісник КНТЕУ. 2018. № 5. С. 5-18.

4. Чугунов I.Я. Бюджетна стратегія суспільного розвитку. К.: Київ. нац. торг.-екон. ун-т, $2021.532 \mathrm{c}$.

5. Чугунов I.Я., Самошкіна О.А. Видатки бюджету в системі державного регулювання соціально-економічного розвитку країни. Вісник КНТЕУ. 2019. № 2. С. 103-121.

6. Budget policy of social development. Chugunov I., Kaneva T., Pasichnyi M. and other. General editorship Chugunov I. Scientific Route. Tallinn, Estonia. 2018. 348 p.

7. Chugunov I., Makohon V., Markuts Y. Budgetary policy of the emerging countries in conditions of institutional transformations. Problems and Perspectives in Management. 2019. Vol. 17, Issue № 4. Pp. 252-261.

8. Chugunov I., Makohon V., Krykun T. Budget strategy in the conditions of economic globalization. Problems and Perspectives in Management. 2019. Vol. 17, Issue 3. Pp. 101-110.

9. Chugunov I., Makohon V. Budgetary projection in the system of financial and economic regulation of social processes. Baltic Journal of Economic Studies. Vol. 6. 2020. № 1. Pp. 130-135.

10. Chugunov I., Pasichnyi M., Koroviy V., Kaneva T., Nikitishin A. Fiscal and Monetary Policy of Economic Development. European Journal of Sustainable Development. 2021. № 10 (1). Pp. 42-52.

\section{References:}

1. Chuhunov, I.Ya. Kanieva, T.V. and Pasichnyi, M.D. (2018), Biudzhetno-podatkova polityka u systemi rehuliuvannia ekonomiky: monohrafiia [Budget and tax policy in the system of economic regulation], Hlobus-Press, Kyiv, Ukraine.

2. Samuel'son, P.E. and Nordkhaus, V.D. (2015), Ekonomyka [Economics], Vyl'iams, Moscow, Russia.

3. Chuhunov, I.Ya. and Makohon, V.D. (2018), "Budget strategy in the conditions of economic transformations", Visnyk KNTEU, vol. 5, pp. 518.

4. Chuhunov, I.Ya. (2021), Biudzhetna stratehiia suspil'noho rozvytku [Budget strategy for social development], Kyiv.nats.torh.-ekon. un-t, Kyiv, Ukraine.

5. Chuhunov, I.Ya. and Samoshkina, O.A. (2019), "Budget expenditures in the system of state regulation of socio-economic development of the country", Visnyk KNTEU, vol. 2, pp. 103121.

6. Chugunov, I. Kaneva, T. and Pasichnyi, M. (2018), Budget policy of social development, Scientific Route, Tallinn, Estonia.

7. Chugunov, I. Makohon, V. and Markuts, Y. (2019), "Budgetary policy of the emerging countries in conditions of institutional transformations", Problems and Perspectives in Management, vol. 17, no. 4, pp. 252-261.

8. Chugunov, I. Makohon, V. and Krykun, T. (2019), "Budget strategy in the conditions of economic globalization", Problems and Perspectives in Management, vol. 17, no. 3, pp. 101-110.

9. Chugunov, I. and Makohon, V. (2020), "Budgetary projection in the system of financial and economic regulation of social processes", Baltic Journal of Economic Studies, vol. 6, no. 1, pp. 130-135.

10. Chugunov, I. Pasichnyi, M. Koroviy, V. Kaneva, T. and Nikitishin, A. (2021), "Fiscal and Monetary Policy of Economic Development", European Journal of Sustainable Development, vol. 10 (1), pp. 42-52.

Стаття надійшла до редакиї 06.01.2022 p.

ВИААННЯ МОЖНА ПЕРЕАПААТИТИ З БУАЬ-ЯКОГО МІСЯЦЯ! - ЧЕРЕЗ РЕААКЦІЮ (ТЕ. . 458-10-73);

- ЧЕРЕЗ АП "ПРЕСА"

(У КАТААОЗІ ВИААНЬ УКРАЇНИ);

- ЧЕРЕЗ ПЕРЕАП ААТНI АГЕНТСТВА 